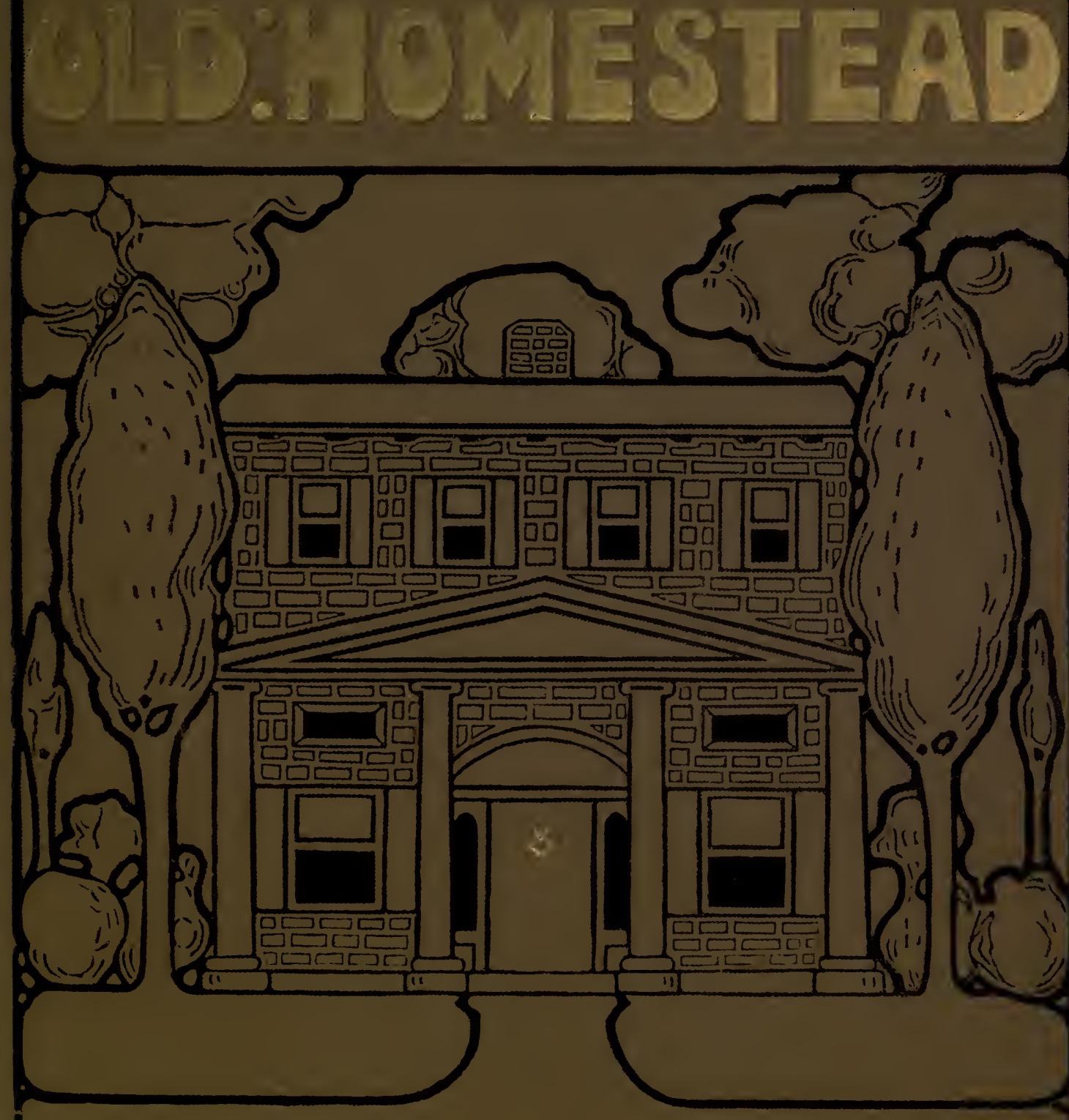


BIU.AGRICULIUTALL LIBRARY UNIVERSITY OF CALIFORNIA RIVERSIDE, CALIFORNIA 92521

\section{LIBRARY UNIVERSITY OF CALIFORNIA RIVERSIDE}


aprie 7, 1907Marry happly retimns of the doy
to Dapa from Lie loving dangeter,
Oga. 


\section{Digitized by the Internet Archive in 2007 with funding from Microsoft Corporation}

http://www.archive.org/details/aroundoldhomeste00hustiala 



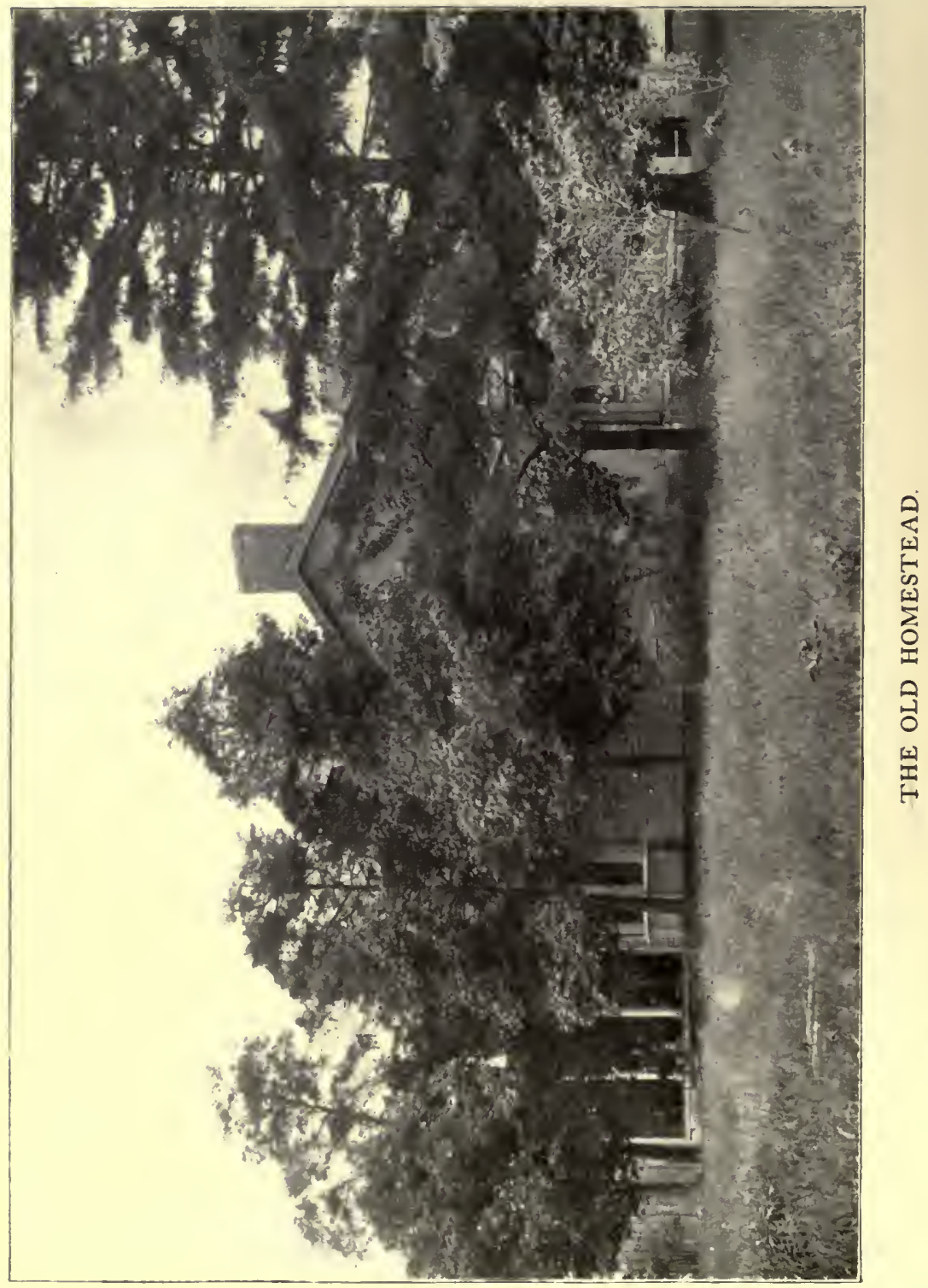




\section{AROUND AN OLD HOMESTEAD}

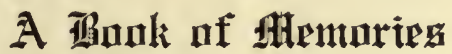

\section{By \\ PAUL GRISWOLD HUSTON}

Author of

"An Old-Fashioned Sugar Camp

aNd Other Dreams of the Woods"

CINCINNATI: JEN INGSAND GRAHAM N E W Y O R : E A T O N A D M A I N S 


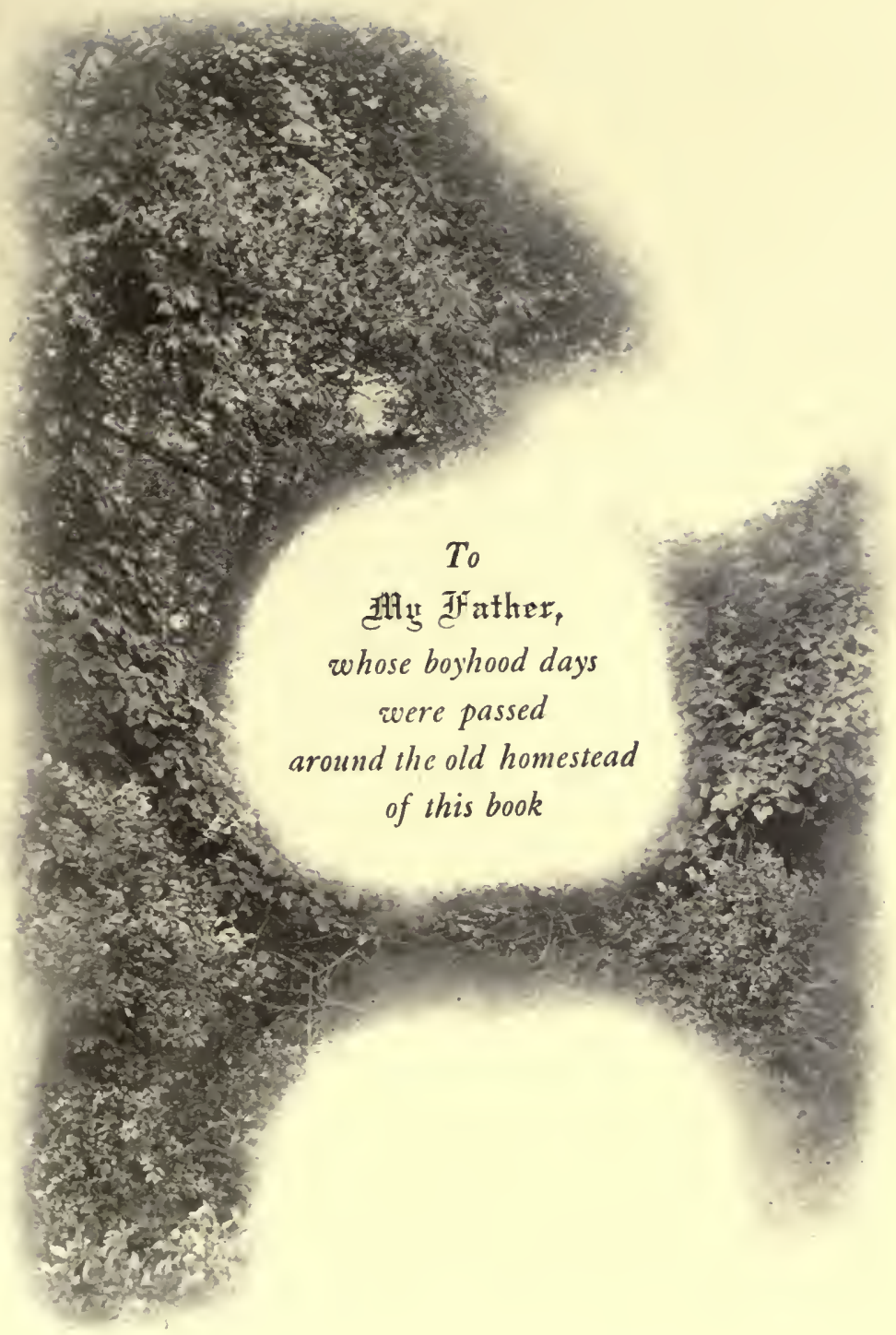





\section{PRE F A C E}

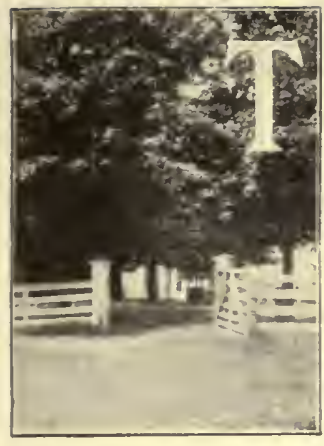

THE BARNYARD GATE.

HIS is but a small sheaf among many others; for, as the floor of the woods is covered with fallen leaves and pieces of detached bark, so the little woodland of my thoughts is strewn over with these rough fragments and memories. Yet the old homestead still stands as I have written it. There is no latchstring. It is always open to receive us.

I wish I could say that I have in this book made some distinct contribution of my own to the appreciation and enjoyment of the beauty of life. But it has at least expressed my trying, and the intent perforce must be taken for the deed.

We can not all realize in our individual experiences the life-thoughts of many diverse minds. We can have but one attitude toward the world. I should feel, then, at least repaid, if these pages, written at odd moments among the fields and in the woods and before the open fireplace, and again beside the waters of remembrance, could join some other pilgrim with myself, at this wayside shrine, in the worship of what we shall call Nature, the beautiful, and the things of the spirit.

Bevis, Оніо,

PAUL GRISWOLD HUSTON.

August, 1906. 



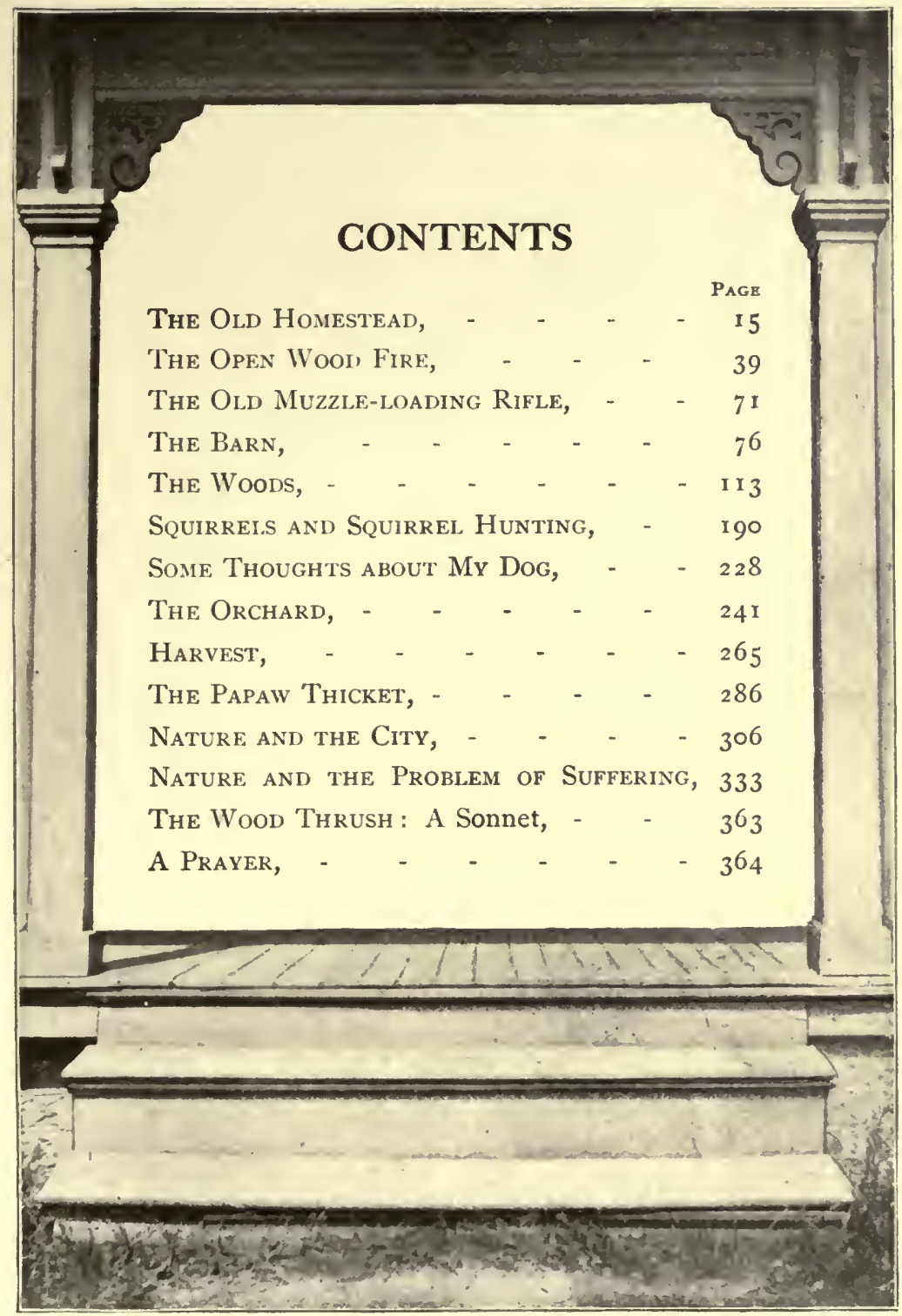




\section{NOTE}

NeARLY all of the illustrations are from amateur photographs taken expressly for this book by Mr. George N. Jennings, Mr. James W. Young, and the author, but of these Mr. Jennings has contributed by far the greatest number. I am indebted, however, to Mr. Alexander Thomson for the picture entitled "Man's Best Friend," to Mr. Lee Harris Huston for "'The Squirrel Hunter," and to Mr. Ernest Harold Baynes for "'The Gray Squirrel.', Of professional photographers, Mr. Paul Fleur has given his assistance with the frontispiece, "Old Spot and Her Owner," and "A Country Lane," and Mr. A. E. Rosebaum with "The Old Fireplace." The illustrations are believed to reproduce faithfully many of the typical scenes and occupations around the old homestead. 


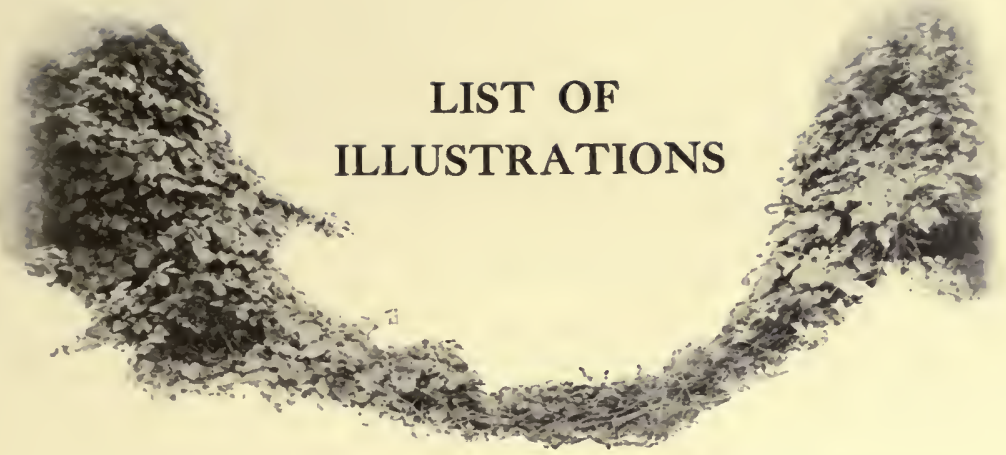

The Old Homestead.

Frontispiece.

A Grapevine Festoon, - - $-\quad$ - $\quad$ - $\quad$ - $~-3$

The Barnyard Gate, - - - - $\quad$ - $\quad$ - 5

The Front Entrance, - - - - - - - - -

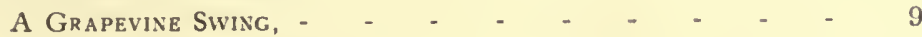

The Porch BY THE Well, - - - - - - - -15

THE ROCKERY, - $\quad$ - $\quad$ - $\quad$ - $\quad$ - $\quad$ - $\quad$ - 21

"Wild Flowers and Ferns," - - - - - - - $\quad$ - 22

The Bed of Red IIllies, - $\quad$ - $\quad$ - $\quad$ - $\quad$ - 23

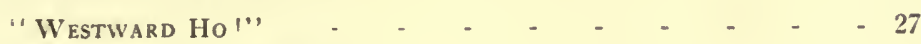

The Parlor in Summer, - $\quad$ - $\quad$ - $\quad$ - $\quad$ - $\quad$ - $\quad$ - 29

"The Old Oaken Bucket," - - - - - - - - 32

"The Decent Church that Topped the Neighboring Hill," 34

A GABLE, - - $\quad$ - $\quad$ - $\quad$ - $\quad$ - $\quad$ - $\quad$ - 36

The Old Fireplace, - $\quad$ - $\quad$ - $\quad$ - $\quad$ - 38

The Old Sugar Kettle, - $\quad$ - $\quad$ - $\quad$ - $\quad$ - $\quad$ - $\quad$ - 39

SPLIT WOOd RANKED UP IN THE WoOds, - - - - $\quad$ - 48

The WoOdShed, - $\quad$ - $\quad$ - $\quad$ - $\quad$ - $\quad$ - 51

THE EMBERs, - $\quad$ - $\quad$ - $\quad$ - $\quad$ - $\quad$ - $\quad$ - 69

The Old Muzzle-loader, - $\quad$ - $\quad$ - $\quad$ - $\quad$ - $7 i$ 
The Henry, - $\quad$ - $\quad$ - $\quad$ - $\quad$ - $\quad$ - 72

Antlers ANd Powder-horn, - $\quad$ - $\quad$ - $\quad$ - $\quad-\quad 75$

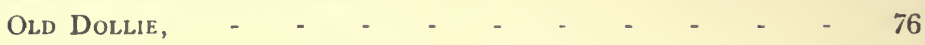

THE BARN, - $\quad$ - $\quad$ - $\quad$ - $\quad$ - $\quad$ - $\quad$ - $~-77$

Ihe Shadow of a Cloud (A View from the Barn Door), - 81

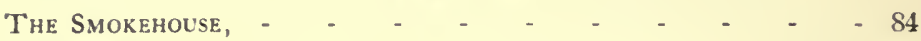

The Old SAdDlebags, - $\quad$ - $\quad-\quad-\quad-\quad-85$

A Drink at The Trough, - $\quad$ - $\quad$ - $\quad$ - $\quad$ - 87

"The Cows are Coming Home," - - - - - - $~ 89$

Old SPOT ANd Her OWNer, - $\quad$ - $\quad$ - $\quad$ - $\quad$ - $\quad$ - $\quad$ - 91

Pitchfork AND Flall, - $\quad$ - $\quad$ - $\quad$ - $\quad$ - $\quad$ - 110

A Stretch of the Woods, - $\quad$ - $\quad$ - $\quad$ - $\quad$ - 112

A Mossy LoG, - $\quad$ - $\quad$ - $\quad$ - $\quad$ - $\quad$ - $\quad$ - $\quad$ - $\quad$ - $\quad$ - 113

“The Vast Cathedral of God's Trees," - - - - $\quad-115$

The Road Through the Woods, - $-\quad$ - $\quad$ - $\quad$ - 121

“AN Abandoned Path," - $\quad$ - $\quad$ - $\quad$ - $\quad$ - $\quad$ - $\quad$ - $\quad 127$

The Old Rall FeNce, - $\quad$ - $\quad$ - $\quad$ - $\quad$ - 133

"Yonder . . We Can See the Sugar Camp," - - - - 141

A Prostrate Monarch, - $\quad$ - $\quad$ - $\quad$ - $\quad$ - $\quad$ - $\quad$ - 146

A Seat IN The Forest, - $\quad$ - $\quad$ - $\quad$ - $\quad$ - $\quad$ - 147

Twisted Trees, - $\quad$ - $\quad$ - $\quad$ - $\quad$ - $\quad$ - $\quad$ - 150

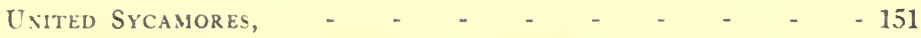

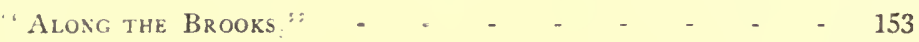

“The Old Hone Tree," - $\quad$ - $\quad$ - $\quad$ - $\quad$ - $\quad$ - 156

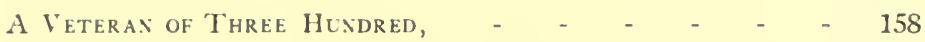

"Wreathed Pllilars of Iiving Green," - $\quad$ - $\quad$ - $\quad-165$

TWIN SISTERS, - $\quad$ - $\quad$ - $\quad$ - $\quad$ - $\quad$ - $\quad$ - $\quad$ - $\quad$ - $\quad$ - 167

“The Eyelashes of the Forest,"

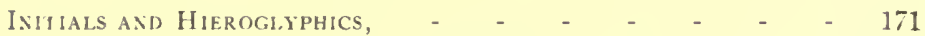

"The Scishine Motrling the Leaves," - - - - - -177

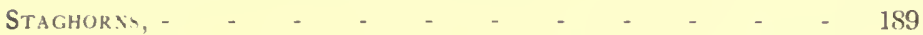

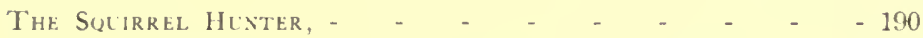

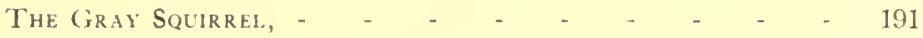

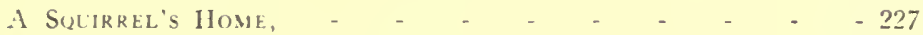

MAN'S BeST FRIEND, - $\quad$ - $\quad$ - $\quad$ - $\quad$ - $\quad$ - $\quad$ - 228 
Mac's Collar,

The Orchard: With the Vineyard and Farm Bulldings in the

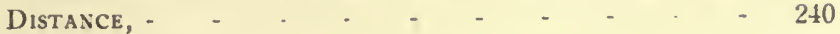

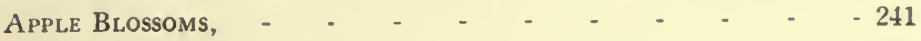

Picking APPles, - $\quad$ - $\quad$ - $\quad$ - $\quad$ - $\quad$ - $\quad$ - $\quad$ - 243

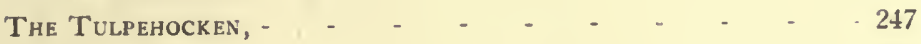

The Cider Press, -

"We Can Hang Our Scythe Conveniently in Some of the

GNarled and Crinkled Crotches, - - - $\quad$ - 255

A Bough of APples, - $\quad$ - $\quad$ - $\quad$ - $\quad$ - $\quad$ - 264

Sickles, - $\quad$ - $\quad$ - $\quad$ - $\quad$ - $\quad$ - 265

IN THE HAYFIELD, - $\quad$ - $\quad$ - $\quad$ - $\quad-\quad-\quad 267$

AfTER THE LOAD, - $\quad$ - $\quad$ - $\quad$ - $\quad$ - 271

“ Littrle Brown Jug, Do N’t I Love Thee!” _ _ - - - 274

Cradling Wheat, - $\quad$ - $\quad$ - $\quad$ - $\quad$ - $\quad$ - 275

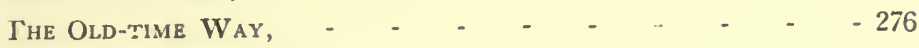

Modern Harvesting, - $\quad$ - $\quad$ - $\quad$ - $\quad$ - $\quad$ - 277

"What Shall the Harvest Be ?" - - - - - - 278

The Harvest, -

Papalvs, with a SPray of Leaves, - $\quad$ - $\quad-\quad-\quad-\quad 286$

A PapaW Woods, - $\quad$ - $\quad$ - $\quad$ - $\quad$ - $\quad$ - 287

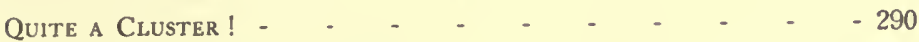

"The Wigwams of the Forest," - - - - - - 293

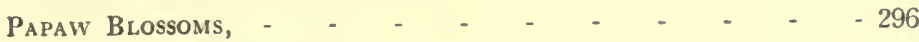

A Clump of Papaiv Leaves and Fruit, - - - $\quad 305$

A Country Lane, - $\quad$ - $\quad$ - $\quad$ - $\quad$ - $\quad$ - $\quad$ - 306

Country Pastimes, - $\quad$ - $\quad$ - $\quad$ - $\quad$ - $\quad$ - 307

"Where are the Flowers, aNd Where is the Grass?"” - 317

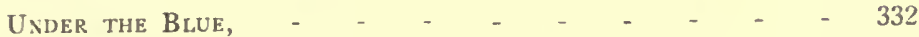

A Plundered Nest, - $\quad$ - $\quad$ - $\quad$ - $\quad$ - $\quad$ - $\quad$ - $\quad$ - 333

"The Lilies of the Field," - - - - - - - 362

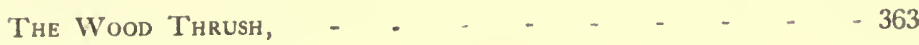



AROUND AN OLD HOMESTEAD 
"SWEET Auburn, loveliest village of the plain, Where health and plenty cheered the laboring swain, Where smiling Spring its earliest visit paid, And parting Summer's lingerings blooms delayed! Dear lovely bowers of innocence and easeSeats of my youth, when every sport could please! How often have I loitered o'er thy green, Where humble happiness endeared each scene!" -Goldsmith. 


\section{THE OLD HOMESTEAD.}

"There is an appearance of comfort and freedom about this old house that renders it a pleasing object to almost every eye. . . . The charm of these old houses, which are marked by neatness and plainness, and by an absence of all pretension, is founded on the natural yearning of every human soul after freedom and simplicity.

-Wilson Flagg.

"But I warrant you'd find the old as snug as the new did you lift the latch, For the human heart keeps no whit more warm under slate than beneath the thatch."

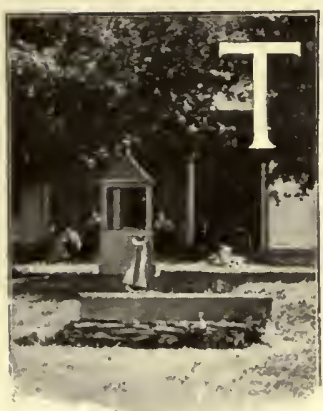

THE PORCH BY THE WELL.

-Alfred Austin.

HERE are few more picturesque spots than the gently rolling country of southwestern Ohio. The old homestead of which I write nestles quietly among its hills. It is not far distant from the historic Fort Colerain, or Dunlap's Station, as it was sometimes called, on the bluffs of the Great Miami, where, in the winter of I790-9I, an attack was made on the garrison by Indians, led by the renegade Simon Girty, and a detachment of soldiers had to be sent out from Fort Washington, on the Ohio, to their aid. The old earthworks of the fort can yet be distinguished in outline from the highway along the river. The upward slopes across the stream can be seen very plainly from our vantage point; and it is one of the diversions on clear days to observe that part of the country through a field glass, and pick out the various farms, and speculate upon the buildings and fields that are too obscure to determine definitely. 
An old log cabin, double-roomed, once stood near the site of the present homestead, in pioneer days, and still another, for temporary occupancy, while the farmstead was in building. It was in the former of these that grandfather kept all his money, hid behind a loose chunk, or board, in the attic. There was a little square hole left in the logs, on the ground floor, and through this the children used to peep at the travelers along the highway. A path led out to the road, and they crossed the fence by means of a stile. I have reconstructed the old cabin in my thought, surrounded with roses, and with its clapboard roof, its plowed-andgrooved board floor, and its old-time windows (some of the pioneer cabins boasted puncheon floors, and had tanned deerskins for the panes), and I know of one old man who was born in it who has since become a lawyer and judge in a great city, and whose practice has extended to the highest tribunal in the land, the Supreme Court of the United States at Washington.

Most of these log cabins of the early settlers have long ago been superseded by more substantial structures; but the attachment of their descendants to these old homesteads has generally kept them in possession of the family line, and each has its legends that go back to the Indians. My grandfather's was located in a region evidently once a favorite haunt of the red man. Flints, even now, are plowed up nearly every year. Indeed, one field used to be so strewn with arrowheads that we thought it must have been the scene of a battle, or at least the site of an encampment.

Starting from his father's farm, some few miles away, on horseback, with his money in silver in the 
saddlebags, my grandfather came to this, his final home, in January, I 822 , almost blazing his-way through the woods; and here he began the hard life of a pioneer, felling trees and opening up the land for cultivation. His father had settled near the homestead in I795, not long after Mad Anthony Wayne had gone through these parts after the Indians, having come from Pennsylvania to the Western frontier with just one hundred and fifty dollars in silver, which he had saved from the wreck of the Continental currency; and his father had been a soldier in the Revolution, and gave his life at the battle of the Brandywine. He (grandfather's father) simply followed Wayne's trail, or the old military road, until he found the situation he wished, and there settled. The homestead was a gift to his son, for the old gentleman managed to leave a large farm to each of the seven children that survived him; and grandfather, having the choice of two, between one in the bottoms and one on the hills, chose this on the upland. In later years grandfather added to his original patrimony by purchases of adjoining tracts, until finally he footed up the grand total of some three hundred and sixty solid acres of some of the best farming land in the county-one hundred acres of woodland, and the rest in pastures and tilled ground.

Grandmother herself had in I 820 , at the age of seventeen, along with others, made the long trip in a prairie schooner from far-off New Jersey, in the dead of winter, cooking her meals, as did the rest, by openair fires all through the snow-clad Alleghanies. She came with memories of how her mother, when once in attendance as a young girl at Commencement Day 
at the College of New Jersey, at Princeton, had been assisted up the steps of Nassau Hall by no less a personage than General George Washington himself, who was present on the occasion, and whom the ladies had honored with garlands of roses; reaching here finally, in the frontier West, to become the wife of a pioneer farmer. Far back there in New Jersey, too, shortly after the War of I 8 I 2, at a tavern where grandmother was once visiting, a coach had stopped before the door, and a lady had alighted from it for her dinner-a lady who was on her way to Philadelphia to meet her husband, General Winfield Scott, who had just acquired fame at the battle of Lundy's Lane, near Niagara. The family had come West four years before grandmother came, but her mother had missed the girl, and so sent her brother and a neighbor far back towards the ocean, for her to leave home and kindred and join fortunes with them in the West beyond the mountains. And it was that same girl who, years afterward, once stood a whole squad of soldiers at bay, while she protected her property and demanded back the young horse which they had taken, because it belonged to her son, who was fighting for the Union in the war.

Now grandfather himself was quite a hero-worshiper. They would flatboat their grain and other produce to New Orleans in pioneer days, :nd be gone a month or over; and on the return on horseback overland through the Indian nations, and through Mississippi, Tennessee, and Kentucky, grandfather once saw, just below the city of Nashville, General Andrew Jackson, who bowed and spoke to him on the wayside. Jackson had a colored servant with him. When the party reached Nashville and learned it was actually 
Jackson they had seen, they felt like going back to meet him again; for no mere passing salutation would have sufficed to show their loyalty to the general.

There is no doubt that hordes of Indians have threaded the woods that once covered all the land on which the old homestead now stands. It has been one of the traditions hereabouts that an old Indian, of the Miamis, and not so many years ago at that, used to come back and visit certain families-especially those of hunting proclivities-and stay again for a while among the scenes and hills that he had loved so well.

After the wedding, on January I 5, I 822 , grandfather took his wife in front of him on horseback, and they thus made their honeymoon together to the cabin; and there, and in the homestead, they lived together for over fifty years. My father, when a lad but eight or ten years old, until the country was opened up, followed, in company with his sister, a blazed trail made by grandfather through a woods three miles to school; and it was a dark and lonesome trip, with the experience, too, of occasionally getting lost, while the reports of panthers traveling westward at the time made the danger seem much greater. Mush and milk was a common diet; and the boys' clothes in grandfather's time used to be homespun, made of wool sheared from his own sheep, which he drove down and washed in the river, four miles away. The fleece was made into rolls at the carding mill down by the river, and then spun into thread by grandmother at the homestead, and finally woven into patterned cloth for them at the fuller's. Grandmother used to spin flax also, and trousers and coats were made of the tow for the boys. All the blankets on the farm were of home manufac- 
ture, and she knitted their own socks. Grandmother herself would ply the wheel, with its distaff and spindle, and sing the ballad of "Barbara Allen" and the other tunes of long ago. It is not often that an old-time spinning wheel is seen nowadays, at least in operation. The one used by grandmother is still kept at the homestead, as a sort of relic, or reminder, of the days that have gone. Their life seems free and beautiful, as we look at it, in those olden days. I think of Priscilla and John Alden. Yet theirs was but one of numerous other such pioneer experiences out here in the Western wilderness.

The house-like "Clovernook," and not far from it - was built of bricks made from clay dug on grandfather's own land, a stone's throw from the site of the building. Oxen turned the great poles and wheels in the mixing. They were large bricks, of the old-fashioned kind; and the foundation walls, too, came from the farm, and the lumber for the woodwork, and the big rough stones that flag the porches' entrances. Grandfather had his own lime kiln, and burnt the stones from the brook for the lime for his mortar. The date of the erection, I834, was graven on the lintel, above the doorway-not so very ancient, it is true, but still far enough back to leave an atmosphere of romance and old-time ways lingering about the place and curling up in the fragrant wood-smoke from the chimneys. Threads of poetry twine about it with the woodbine which clambers over the walls and waves its sprays across the windows. Within its ivy-mantled sides one may get a glimpse of the older generations and their life, now almost passed away. The old homestead itself seems almost a thing of the past, so linked 
are all its associations with the times of sixty years ago. There is an atmosphere of age about it which makes it exceedingly restful in these rushing times of to-day. It is like a cool, mossy spring beside a dusty road.

We can see it, as we approach, by the tops of the spruces, or the big black walnut out by the gate. The place is surrounded with evergreens and maples, and there was a large hemlock at one time near a summerhouse bowered in roses. Two enormous Mayduke sweet cherry-trees formerly grew in the front yard, one with great expanding limbs, like an oak, and with a trunk diameter of close to thirty inches-the wonder, and, in cherry time, the envy, of all who saw it. Myrtle spreads beneath the spruces; two dogwoods, planted years ago, blow masses of white in springtime; petunias and roses paint the walks; hollyhocks border the buildings; nasturtiums nod and sprangle in the rockery; wild flowers and ferns from the woods droop and play in under the cedars; and a bed of red lilies colors the way to the garden. With its broad open

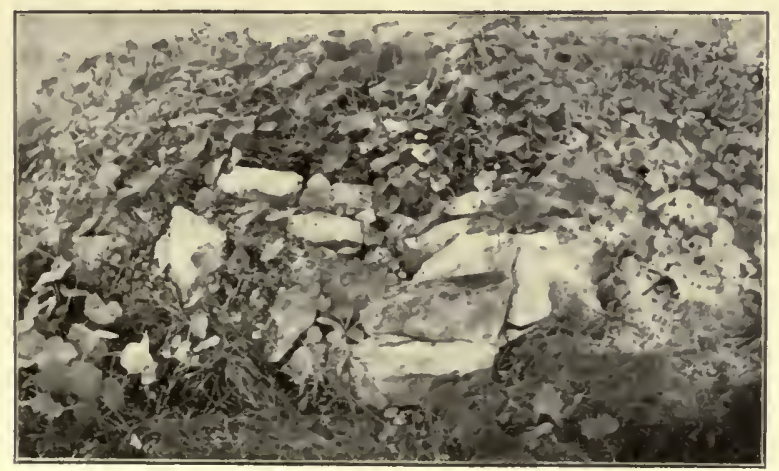

THE ROCKERY. 
lawn, 't is a place for archery; a spot, too, for boxwood hedges and a sundial. Croquet, however, has had its innings as the favorite outdoor amusement, and

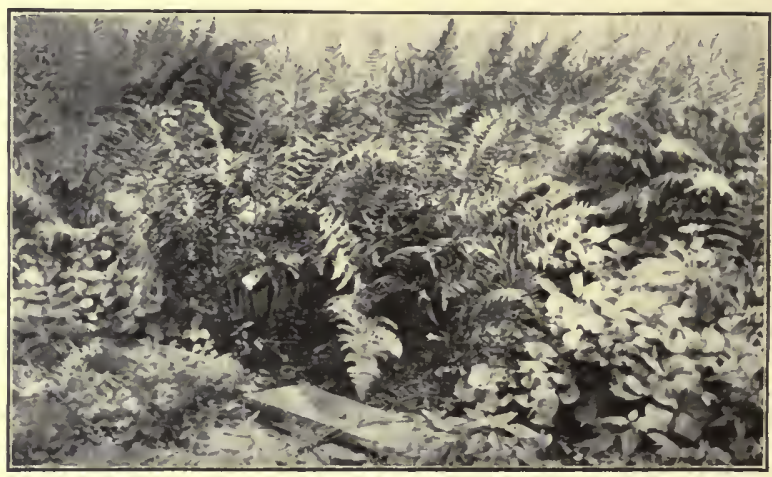

“'WILD FLOWERS AND FERNS.'

many a stiff game of quoits has been pitched across the sward with horseshoes.

Waxwings build their nests amid the cedar boughs that brush the house; a bluebird yearly has its home in the hollow limb of a dead sweet cherry; the little nests of song sparrows are well concealed there among the blackberries; and English sparrows chirp and twitter about the eaves, and long straws from their nests hang from the corners. In the days cardinals and robins and many other beautifully colored birds come whisling and fluting about it; toward nightfall swallows dart and soar above, and bats flutter and girate to and fro, while katydids rasp away in the maples, and the crickets drone out in the fields; and later, in the dusky places, the whip-poor-wills and screech owls cry, while round about whispers the never-ending soughing of the pines and spruces. 
Formerly great flocks of wild pigeons used to fly over the farm, sometimes even darkening the sun in their flight-pigeons, pigeons everywhere, as far as the eye could reach. Wild turkeys piped through the woods, and wolves came up back of the barn at night and howled. But these have all gone, and it is a rare thing nowadays to see even a single little flock of a dozen wild pigeons, and the people remember the year when they see them.

Around upon the estate are various orchardsapples, pears, quinces, apricots, peaches, cherries, plums; and many kinds of berries-strawberries (of which, 't was said, so tells old Izaak Walton, that "doubtless God could have made a better berry, but doubtless God never did"), red and black raspberries, blackberries, and, some time past, a patch of dewberries

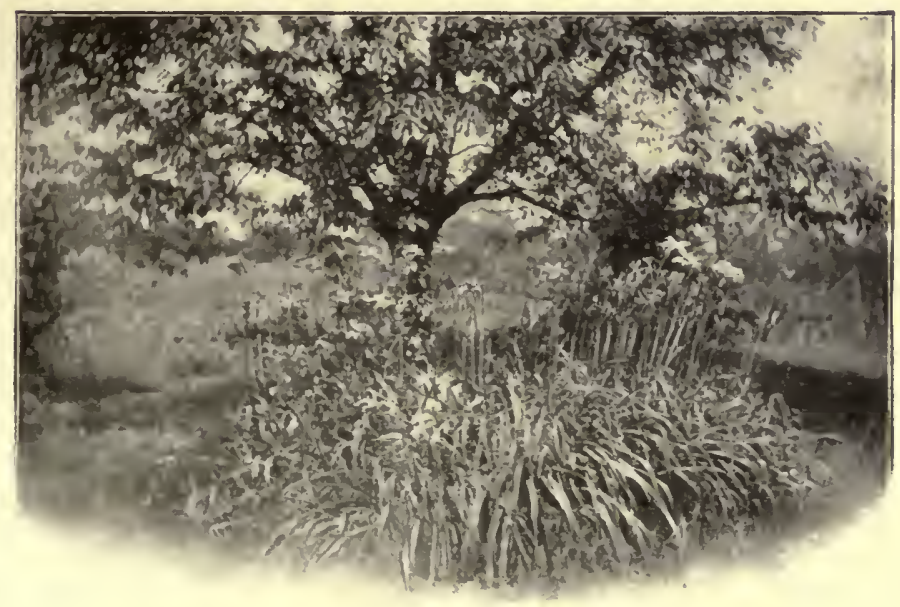

THE BED OF RED LILIES. 
and one of currants. On a hillside gently sloping from the house innumerable clusters of white and purple grapes hang, luscious and sweet, beneath the sheltering shade of the broad green leaves of the vineyard. Pastures flank the roadsides, and fields of clover, wheat, and corn, where golden pumpkins dot the brown earth in the autumn. A large woods serves as a wind-break toward the West, and its masses of dark foliage and the antlered tips intensify and prolong the beauty and mystery of the slow-dying sunsets.

I think of Horace on his Sabine farm. Sometimes, too, as I look at it, I think of Hawthorne and the old manse. ' $\mathrm{T}$ is an ideal life-otium cum dignitate. What more could one wish?

The homestead is one of the few old places now left in this vicinity. Almost all the others have become too modernized. But it is not like our modern houses. It has never been rented; and the people who live in it have never moved. So, although not far from the city, the homestead is suggestive always of old-time memories and old-time customs, and affords one of the unusual opportunities, nowadays, where we can see old-time ways still practiced, the wheat cradled, the maple sap boiled in kettles, soft soap made from the wood ashes, and the open fire in the sitting-room.

During one season ("befo' de wah") as many as one hundred and fifty thousand hogs were driven past along the turnpike down to the city of Cincinnati, at that time the great pork market of the country. The old homestead became a sort of tavern at such times, and the drovers used to stop over night. The road would become all ruts and wallows. But all that has 
changed, too, with the years, and the extension of railroad facilities and the opening of the many other Western packing-houses have sadly diminished the great droves of hogs; yet even I can remember more than once seeing the turnpike black with droves containing several hundred, and great herds of lowing cattle, and flocks of hundreds of sheep as well, panting and bleating along on their way to the stockyards.

How many memories there are that thus cluster about an old house! The customs and loves of years ago are there-1834. The old people now living in it can tell of incidents that occurred in the first campaign of Martin Van Buren; and the recollections of the aunts go back even further, to a time when, as little girls, they had listened to the tales of a neighbor, an old woman then, who was the daughter of a soldier of the Revolution. She had, as a child in New Jersey, baked loaves of bread, very long, large loaves, for the American soldiers; and once, when fired upon by the British, she had jumped over a fence, and had fallen as if dead, and had then been left there by them. The old homestead, as I have said, is also itself practically on the site of a $\log$ cabin built in pioneer days, and the well in the yard dates back to the earliest settlements in the Miami Valley. It has never been rewalled, and its moss-covered stone sides still contain the sweetest, best of sparkling water in the world. When we hear these tales, and think of these associations with the past, it stirs our blood, and it is almost as if we were ourselves thus joined in a way, and link by link, to the very origin of the Republic.

Afar off, at certain times, I used to (and can yet) 
hear faintly, floating up in sweet mellow tones, the deep whistles of the big river steamers on the Ohio, fifteen miles away; and in the distance, again, across the rolling hills, on still days, could be heard the rumble and tooting of the train on its way toward the North. I used to think it one of the wildest places possible upon such occasions. It seemed as if we were remote and isolated from the whole world, and I enjoyed it.

There is a large picture in the sitting-room, which long ago excited my imagination, entitled "Westward Ho!" A pioneer has just returned from a hunt, and, coming into his lean-to hut with his game-a deer slung over his pony's back, and a raccoon and opossum and some wild turkeys lying on the ground-stands leaning on his long muzzle-loading rifle surveying the scene, while his wife looks up admiringly into his eyes. His oldest boy is taking the deer from the horse; the children are playing about a spring of water; and supper simmers over the open fire beside the spring. A river winds its way not far distant among the hills. An improvised shack is the home, with a roof of bark. The whole picture set the wild blood and love of adventure aglow in me, and I quivered for the life of the forest. It seemed to me then, in my young boyhood days, and still seems, as I look upon it, the symbol of all that is independent and adventuresome and truly American. It speaks of the wild life that used to be when the forests were here upon every hill, and when Audubon could stop for the night and kill a wild turkey for supper at almost any point along the Ohio.

There used to be another picture, in the diningroom, which not only excited my imagination, but 


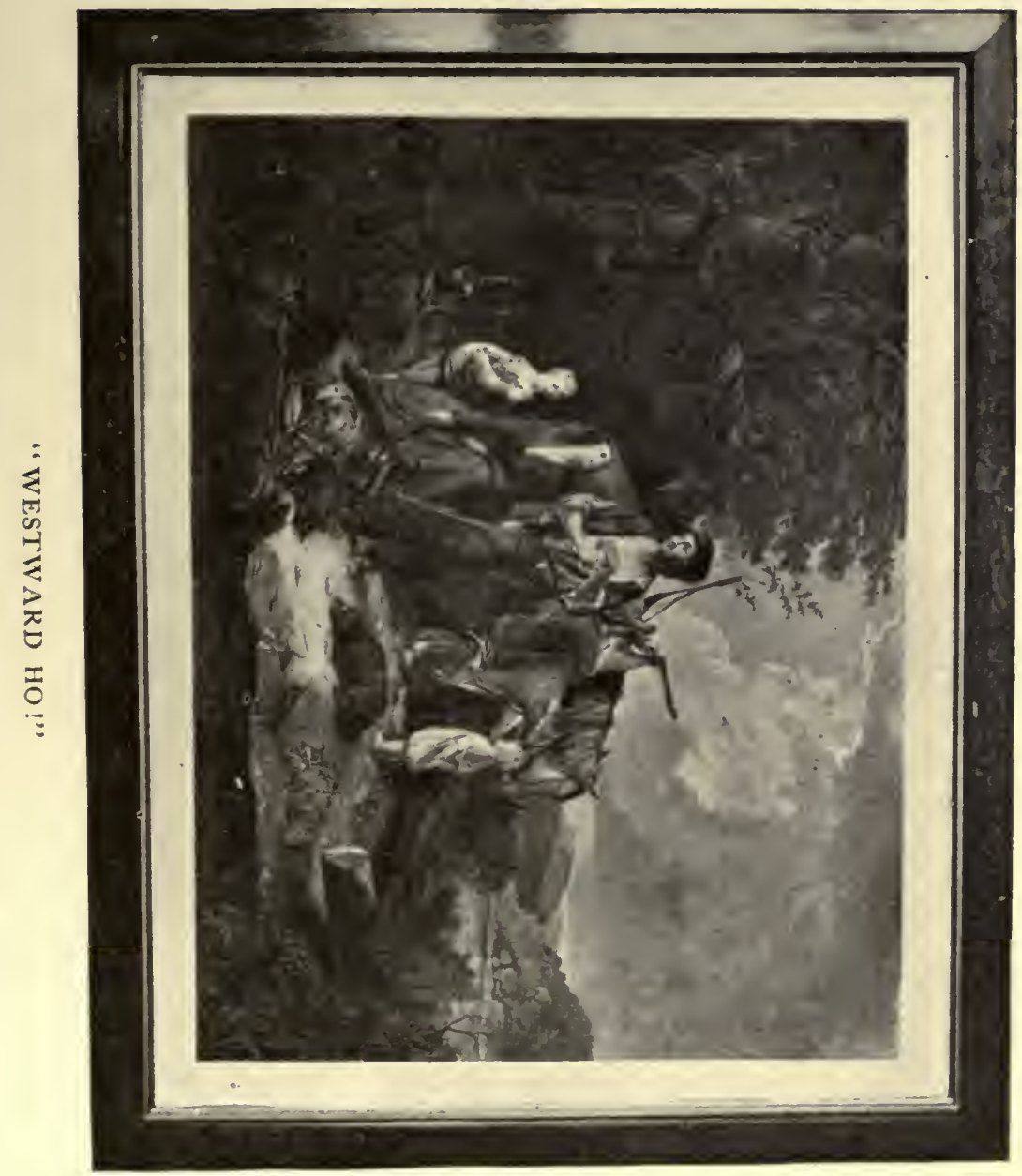



aroused all my patriotism when still young. It represented the early Revolutionary days. A soldier on horseback, with a drum, had hurriedly come to a settler in the fields, to announce the war and to ask for volunteers. The farmer was leaving his team and his plow at the call of his country, and one or two others were hurrying up also with their guns. I suppose it was meant to suggest Lexington times, but I used secretly

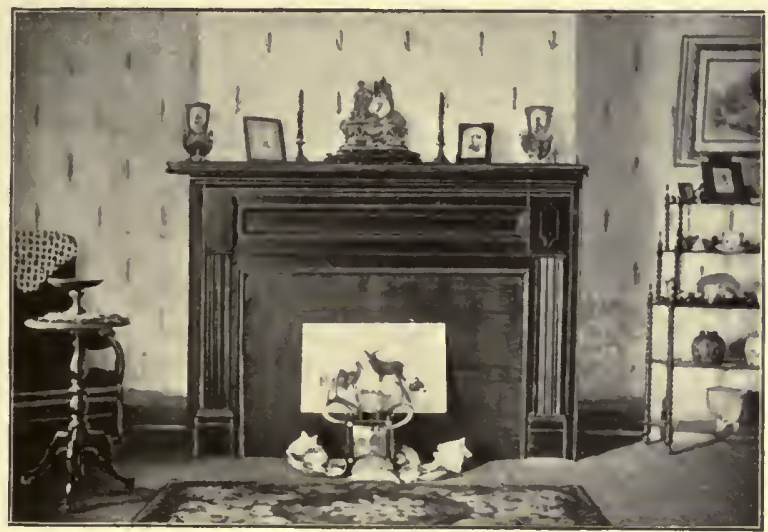

THE PARLOR IN SUMMER.

to hope also that perhaps the patriotic farmer was really General Putnam himself.

The big, cool double parlor, as well as the sittingroom, has a huge open fireplace at each end, in front of which, when unused, lie deer horns and various shells. Heavy wide-opening doors separate the two rooms in the parlor from each other when wished. Grandfather and grandmother celebrated their golden wedding in this room, and on its walls are the family 
portraits, all in a frame together, taken at the time of the golden wedding, no one yet having passed over the border, and the oldest of the ten being then within a year of fifty.

Beneath the parlor is the cool brick cellar, with its tables set with crocks of milk and cream, and, in their season, bins of apples and potatoes, pumpkins and squashes, barrels of cider, and demijohns of wine freshcrushed from the grape.

Old-fashioned silhouettes hang on the walls, or rest on the bureaus, along with several mottoes. The picture frames and mantelpieces are adorned with branches of beautiful scarlet leaves in autumn, and perhaps a short twig with a humming-bird's nest will be laid on a bracket. A tall clock used to stand in the corner of the sitting-room, by the stairway.

In the rooms above are family trees, made in wreaths from the hair of the different members for generations, taken from the locks of every relative, far and near. In one of the front chambers are still to be seen four large iron hooks in the beams of the ceiling, on which hung the quilting frames of years ago. Here, during the days, were held merry quilting parties; and at night the frames were again pulled up and fastened to the hooks, so that the beds underneath could be used. The piles of brightly patched quilts, in their old-fashioned patterns (such as Rising Sun, Jacob's Ladder, Log Cabin, Irish Chain, and Path in the Wilderness-all pioneer names), folded away in the closets, attest the frequent use of these hooks.

The old well is on the crest of a ridge, and that ridge, a very wide one, where also stands the home- 
stead, is the highest point of land in a stretch of forty miles. The well curb has been banked up on the outside somewhat, making a little rise in the ground, so that there is a slight slope on all sides from the opening. This and the fact of its having been dug on the top of a ridge prevent any surface water from filtering through immediately into the well, except in very heavy rains; and it consequently has, in summer and winter, autumn and spring, the same sweetness and purity of taste-the very best water I have ever drunk, from wells, springs, brooks, or rivers, in all the sixteen States in which it has been my fortune to drink water. I have never found any water even at all approaching it except at a well some miles away, and that must have come from the same vein; and when the water is drawn from the northeast corner of the old well, in a genuine "old oaken bucket," I believe nothing on earth can equal it.

This well is known to be at least one hundred years old. It was here when grandfather first saw the place, and the land had changed hands twice before that. The walls have never been renewed-it has never been necessary to rewall it-and the stones are covered with rich green mosses, dripping and sparkling and beautiful. Grandfather thought he would make a new wall some time, but it is left, nevertheless, with its curiously curved sides, just as it was in the eighteenth century, except that we have a new well curb. It is about tiventy-five feet deep, and many a cup, or bucket, or hat, let fall by young or careless hands, has had to be dragged out of it with the grappling hooks. I love to look down into its cool, black depths. A drop from 
a spray of moss falls with a bell-like tinkle, and concentric rings spread from its center, causing the surface of the water to shiver and dance in diminutive wavelets rippling lightly from one side to another. Here, at least, whether in harvest-time or when snow is drifting, one can always have a cup of the water of life (shall we say?), clear as crystal, icy-cold, and as sweet as the sap which falls from the maples. One end of the windlass, which is nearly as old as the well, is as smooth as glass, worn through long years, and showing the grain of the wood as if oiled, where we have held our hands, as a sort of brake, in letting the bucket descend rapidly, instead of slowly turning the handle, thus causing it to plunge at last with a ketchunk! below the surface, to rise again in a shower of spray. Many a stranger, staying for a time to rest in the shade, has been grateful for the refreshing draught it gives. It has become quite famous for its

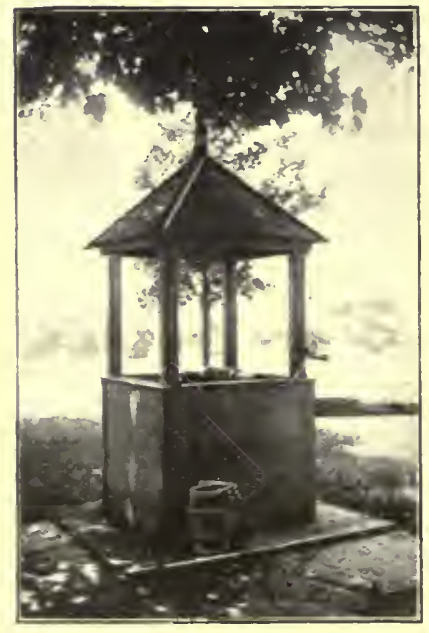

"THE OLD OAKEN BUCKET." water, having been there during the cabin days, and travelers always have stopped beside it.

Sparrows sit on the edges of the long carrying trough (made out of a tree) that leads from the well, and dip their bills in the water as it courses past them, while in the big receiving watering trough at the other end the horses, cows, calves, and chickens, and all the animals on the farm except the hogs slake their thirst, and plunge their noses deep into the crystal pool, or 
cool themselves by letting the stream come gushing against their chops as they drink. How they love it! I have heard that horsehairs, plucked from the horses' tails without others' knowledge, have been turned (curiously!) into long, thin, wriggling snakes, if allowed to remain in the big trough for a certain secret period. There was always something about the old trough that had considerable mystery to it.

Samuel Woodworth has immortalized himself in but one well-known poem, "The Old Oaken Bucket," but that sweet and rustic refrain has made many a heart happier and better in the memory of the delicious draughts of childhood. Who, too, that ever lived in the country, can not repeat the lines with Woodworth, and say,

"How sweet from the green, mossy rim to receive it, As, poised on the curb, it inclined to my lips!

Not a full, blushing goblet could tempt me to leave it, The brightest that beauty or revelry sips."

I think that no better poem was ever written upon country life.

Indeed, the favorite songs of the place have always been after the order of "The Old Oaken Bucket," itself perhaps the most enjoyed; such as "My Old Kentucky Home," "Sweet Alice, Ben Bolt," "Annie Laurie," and "Auld Lang Syne," with "Old Folks at Home," "Blue Bells of Scotland," "Dixie," and "Robin Adair" as close seconds. In the olden days four of the seven boys of the family (there were three girls also) formed a drum corps of their own-two fifes, a rattling tenor drum, and a booming bass-and strolled the country round about at times as the peerless and 
envied rivals of every other band of wandering minstrels.

The old homestead and the hamlet remind me of Goldsmith's poem,

"Sweet Auburn, loveliest village of the plain."

Ah, so it is! Yet I am reminded also of the "Elegy" by the myrtle covered cemetery amid the evergreens, where,

" Each in his narrow cell forever laid,

The rude forefathers of the hamlet sleep "-

and by the barn, and the swallows, and the beautiful evenings, and many other things as well, of that fine old inspiration of Gray's. But things have changed. The village does not now have quite the old-time aspect that once it had. The old families have nearly all passed away, new ones have come in with their modern houses, the woods have pretty well been cut down, even the familiar faces have become altered. Only a memory remains (but 't will linger for aye) of what the village once so poetically stood for in my boyhood. The spirit of reminiscence comes upon me. I see

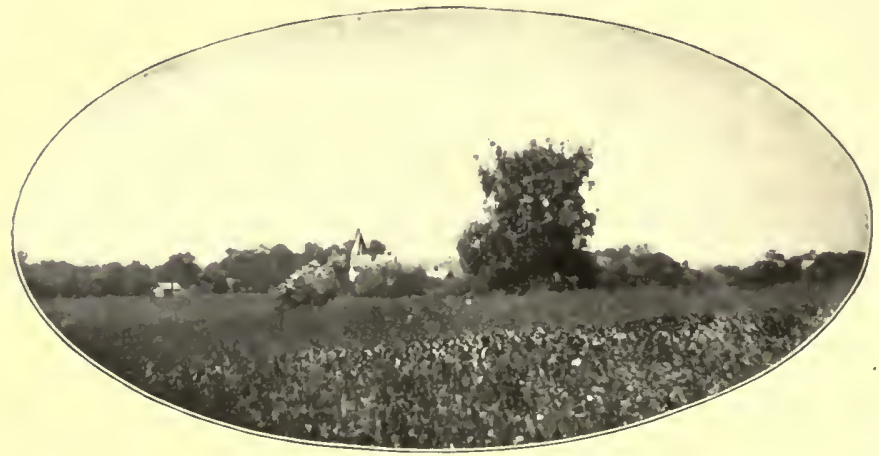

"THE DECENT CHURCH THAT TOPPED THE NEIGHBORING HILl." 
the old place as I loved it years ago, surrounded with its evergreens and maples, in its rural simplicity expressive of all that is good in life. I think of the cool water as it courses down the long trough. I carve my initials on the barn door. I am a boy again, happy and free, and the squirrels are playing and barking in the trees, calling me to them. Ah, I loved the old place! Yet I can not see that I love it any the less now. I think of it as of no other spot. It has changed, as have all things, in the years; but, within its ivy-entwinéd walls-where the good old mottoes, "Live and let live" and "Make friends and keep them," are practiced in the every-day hospitality of life, and where plain living and high thinking are not the exception, but the general rule-here, then, still dwell happiness and old-time living. The atmosphere of the place is one of rest, and quietness, and simple ways. Here one may live in comfort and seclusion, and at peace with the world.

Alice Cary has a beautiful poem entitled "The Old Homestead," and I shall give a stanza or two of it, as, in her fine poetic gift, she has expressed what can best be said in verse, after all, and is therefore a fit tribute to that halo of love and of mystery which still surrounds the homestead of these memories:

\footnotetext{
"When skies are growing warm and bright, And in the woodland bowers

The Spring-time in her pale, faint robes Is calling up the flowers,

When all with naked little feet The children in the morn Go forth, and in the furrows drop The seeds of yellow corn;
} 
What a beautiful embodiment

Of ease devoid of pride

Is the good old-fashioned homestead,

With its doors set open wide !

"When home the woodsman plods with ax Upon his shoulders swung,

And in the knotted apple-tree

Are scythe and sickle hung;

When low about her clay-built nest

The mother swallow trills,

And decorously slow, the cows

Are wending down the hills;

What a blessed picture of comfort,

In the evening shadows red,

Is the good, old-fashioned homestead,

With its bounteous table spread!

" But whether the brooks be fringed with flowers,

Or whether the dead leaves fall,

And whether the air be full of songs,

Or never a song at all,

And whether the vines of the strawberries

Or frosts through the grasses run,

And whether it rain or whether it shine

Is all to me as one,

For bright as brightest sunshine

The light of memory streams

Round the old-fashioned homestead,

Where I dreamed my dream of dreams!"

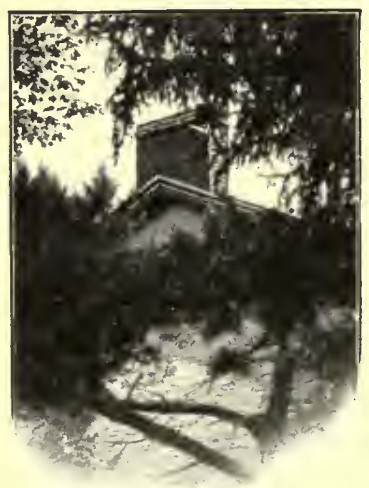





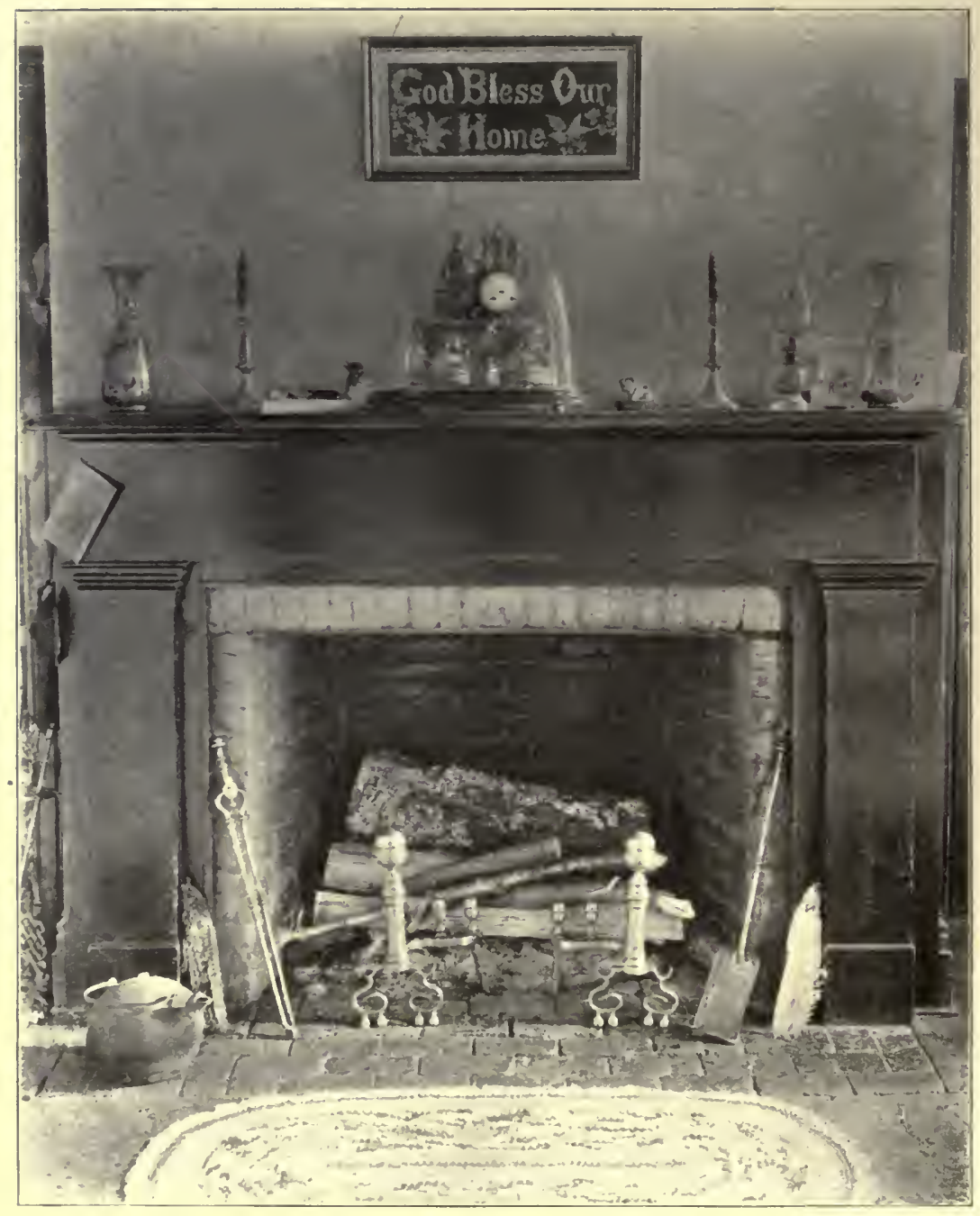

THE OLD FIREPLACE. 


\section{THE OPEN WOOD FIRE.}

"Mankind has never willingly relinquished the camp-fire. It is not preference, but necessity, that has driven him indoors. Even there he carried and rekindled its embers, and it became the hearth-fire: a flame, sister to the flame of love. So much he rescued from the loss of Paradise."

-William Cunningham Gray.

"Then leave that buzzing hive, the city mart;

Come, while my gnarl'd oaks hold their wreath of snows,

Come to a country hearth, and let your heart-

Mellowed by midnight, while the back-log glows-

rouch on the themes most dear."

-Lloyd Miflin.

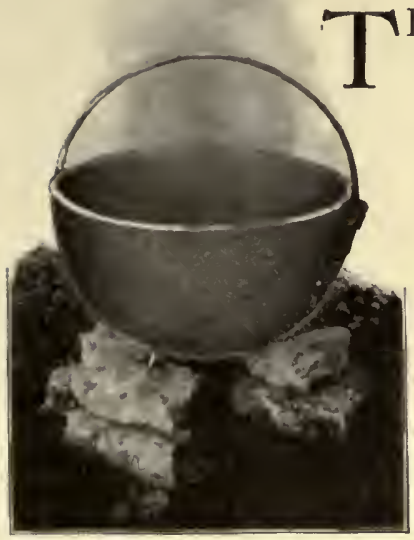

THE OLD SUGAR KETTLE.

HERE is nothing like a wood fire. The blaze crackles out good cheer in truly royal fashion. It is one of the real privileges of country life, a rightly venerated luxury. How clean the wood fire is, and how fragrant and suggestive the perfume of the smoke! There is practically no soot, and the ashes are easily taken away. It's like having a regular outdoor fire in the house, and gives us a chance to live as we ought to, in an atmosphere of mingled coziness and native enjoyment. The fireplace itself is four feet wide and nearly three deep, and the entrance is three feet high and is slightly arched. That will hold a good-sized log, you see, and many a heavy one have I hoisted and flung into it, in constructing the fire, across the dogs. 
The floor is of oak, and has never been renewed, and the hearth is made of large bricks. We can see, in under the edges of the carpet, the ends of the old oak planks, still sound, next to the hearth. A couple of andirons, a foot or so apart, stretch out toward the back of the chimney. The slender iron rods that span the hearth, as parallel supports for the wood, are each elevated a few inches at the rear by a small leg, or pin, which is simply a bent-over extension of the horizontal cross-piece itself; and they are raised at the front to an equal height by two side-projecting feet, or stems, apiece, attached to the framework. Above these fore bases are two large metal uprights, which serve to keep the wood from spreading too far, and to uphold the backlog, should it ever fall forward. These erect and prominent standards are generally of brass (or, rarely, of hand-forged bronze), formed into bosses, or scrollwork, or other studded and armor-like devices, which are sometimes very curiously artistic and ornamental; and, when well burnished, they reflect in a dancing flicker the light of the fire. In pioneer days they were used to sustain the ends of the spits in cooking, and answered the purpose as a sort of trevet. Those in front of the old fireplace before us date from close to the eighteenth century, and are composed of a series of brass knobs one above another, and the braces beneath them are also of brass. The fire irons, too, are often wrought in relief, with very attractive designs in the antique.

It is always interesting to observe the different sizes and kinds of wood thrown on a fire in the making of it. There are few plcasures equal to the building 
of one. First, of course, comes the huge backlog itself, perhaps half a log of sugar maple, preferably green, pounded and riven in two with maul and wedges, and with moss, and shreds of bark, and lichens still hanging to it; and now slung, back of the andirons and propped up by them, aga:rst the chimney, as the reflector and mainstay of the fire and the protection of the chimney walls. Then a good-sized forestick will be placed down in front, close to the uprights and on the transverse shafts; and perhaps that is part of an old dead oak, cut and split up now into wood. A few dry beech leaves, or bean pods, or shucks, may be used as kindlings to start a blaze with, down in between the irons, among the ashes, and set afire by a few live coals raked and poked out from within the embers; and on top of these we shall put a handful of shavings, or some chips, or fragments of an old board or shingle, or a few picked-up splinters from a dilapidated fence rail; while, still further, upon these materials, and resting on the bars, between the forestick and the backlog, we shall lay several smaller pieces of wood similar to the forestick-one, say, of ash, another of beech, a stick or two pruned from the limb of an apple-tree, and some dead leafy twigs of an oak, - and in and out betwixt them all we shall insert some long dry slivers of hickory bark, with perhaps a thick roll from the rind of a beech left standing up against the backlog, or above it, surmounting the whole:- and then we shall have a fire worthy the name! We shall enjoy it, then, through the day, and with our fire shovel at night we shall cover the remaining coals, and the ashes will keep the embers until the morning. 
Hickory bark makes the hottest fire, and for this reason, if obtainable, is always to be preferred in sugarmaking to put under the kettles. But, as a rule, an apple-wood fire is the best for the house, for apple does n't snap, but burns with a steady, beautiful flame; though I like a good sugar fire also. For general purposes as fuel, however, there is practically no wood superior to maple or hickory, though there is almost as much heat given out by the sycamore. I like to use a little of oak and beech, too, if I have it, to add to the variety. Buckeye and sour gum make the best backlogs, outlasting any other kind of wood used for the purpose; but they are not aliways to be had. Whole sticks-limbs, or sections of saplings-are better than split wood for fuel; for the heart wood is the most compact, while that in the outer circles of growth is more porous and full of sap, and is thus less fibrous and radiates less heat. Soft maple makes, in point of quality, the best charcoal of all the trees, but an ash-tree gives the greatest percentage; willow, too, is much used for the purpose. A maple generally turns out about twenty-three per cent of its bulk in charcoal, and an ash twenty-five per cent. Water-soaked or porous wood (like ash and oak) always snaps, as also do hickory and locust. Gas imprisoned there will suddenly explode and send out sparks scattering all over a room, to the sudden discomfiture of the terriers perchance stretched out before the fire, who will start up and scramble back with remarkable antivity. A coal fire may give out a greater heat for its size, but I will venture to say that, if I have a wide enough fireplace, I can muster up a wood fire sufficiently hot for the most 
exacting. The big huge wood fire of pioneer days would heat quite a large room, as the living room generally was; and the same is true of the few open fireplaces still left remaining in the old-time homesteads. There is no need of a stove, if wood is plentiful.

How I love to watch the fire! How it curls and laps around the wood, and licks its way in and out among the foresticks! Sometimes the big backlog itself becomes a mass of red coals, with blue flames playing and hovering above it, or peeping behind the flaky bark that is perhaps still clinging to it. I love to sse it, and to dream before it in midnight fancies. As a child I liked nothing better than to watch the endless flocks of pigeons soaring away in the soot on the chimney's back. The rosy-and-yellow spirals creep and wrap about the burning brands, and over them, and finally leap into beautiful pointed tongues above lapping the chimney, or changing mayhap into sharp fangs, entering and darting up the very funnel, or fleshing their teeth fiercely against the chimney sides. And as the logs hiss and crackle, and send out their heat and steam, I seem to hear in them the music of the woods. It is the orchestra of the oaks and maples and the others together on the hearth there that we hear again now indoors, in the great fire chorus of the trees.

It is a rare enjoyment to poke and tend the fire. Lots of people put a fire out by fixing it. They do n't know how. It is quite an art to know how to stir up a fire aright, and requires a certain instinct which can not be cultivated. A fire-poker, like a turkey-carver, is born, not made.

The evening circle about the fireplace is the orca- 
sion for reminiscences without number of former days. It is the time, too, for many a solemn thought and tender recollection. We warm our toes before ascending to the less hospitable sheets of winter nights, and the little ones go to sleep counting the flocks of pigeons which the flames have started up back there on the bricks among the soot. Yarns-unspeakable for their quaintness and cheerful exaggeration-hunting tales of deer and 'coons, beech and hickory nuts and walnuts, mulled cider and apples, mince and pumpkin pies, and popcorn:- what a time we have of it! There is sure to be a ghost story, and there is generally one at hand right in the neighborhood; but the ghost usually turns out to be the trunk of a tree, with bare arms extended, though frequently the younger hearers are left in an uncomfortable mystery, the thought of which is by no means reassuring when they take at dusk the long tramp through the woods for the cows. Perhaps, on occasion, a few sweet potatoes will be roasted in the ashes, in the old American way, to be whisked out with a turkey wing as a besom; and then, the familar incident of his offering the British officer a mess of baked sweet potatoes served on bark furnishing the theme, extensive moralizings will be entered into upon the valor of Francis Marion's men, with the inevitable conclusion always finally reached that no ore will ever be able to whip America. Or it may be that we shall have a fiddle during the evening, and shall laugh once more at "The Arkansaw Traveler;" or a flute may play for us "Robin Adair."

Every hearthside is the place of immemorial family tradition. How many such farmsteads dot the country 
over, each with its threads of ancestry taking the inhabitants back to their predecessors in New England, or again tracing the generations across to old England, or binding the family ties with Scotland, or possibly other parts of Europe.

A crane, with its trammels, used to stretch out from the jamb into the old fireplace, and a brass kettle hung at its end, over the fire; and there was cooked on the hearth the perennial mush for the evening meal in pioneer days. Why, even after he had graduated from the log cabin, father was still brought up on innumerable bowls of yellow cornmeal mush from the begrimed and blackened old kettle. I have not eaten mush boiled at the end of the crane, but I have helped to boil down maple syrup in that fireplace, in the same old kettle, after the sap had been reduced to a winy consistency in the big caldrons at the camp, whence it was brought up to simmer down still further into thick, golden molasses in the open fireplace; and I have; never felt so full of happiness and romance and poetry as when, amid all these old associations, I made maple syrup that year alone among the trees. The old crane is still about the farm. The brass kettles are still used, and the big iron ones do their duty annually either at the sugar camp or in boiling potatoes" for the hogs. Longfellow's poem, "The Hanging of the Crane," celebrates the beginning of household life, in a sort of house-warming,

\footnotetext{
" As in the chimney, burning bright, We hung the iron crane to-night. And merry was the feast and long."
} 
There was a big brick oven built against the back of the chimney, in the kitchen, in pioneer days, and there were baked the many loaves of bread, and mince and pumpkin pies; and it was no common baking, for a family of twelve. They had a long wooden paddle, broadly flattened at one end, with which they would reach in at the door and lift and draw out the pies.

Things broiled or roasted before an open fireplace, or even cooked on a wood stove, are the sweetest in the world. I recollect serving an apprenticeship in the art when deer hunting one autumn on Lookout Mountain with some Georgia mountaineers; and I remember how at night we would build a big roaring fire in our crude and faulty, but spacious and unceremonious, hearth (we slept in an old cabin), a veritable burning pyre of pine bark piercing the stars, and would then broil bacon over the coals, when the fire had died down.

- We twisted the bacon onto the peeled and sharpened ends of long, slim branches of beech, broken from the trees near at hand, and thus kept at a distance from the heat; and we sometimes broiled two or more pieces on one stick. Now, after this introduction to, and acquaintance with, that primitive and time-honored method of cookery, I have never followed any other when alone in the woods (except to roast things in the ashes, such as potatoes, or ears of sweet corn with the shucks still on them, or a quail rolled in mud), and I find that it serves well for squirrel, rabbit, or venison, the only disadvantage being that the meat, if not cooked aright, becomes rather dry from the lack of basting which roasting in an oven affords. But take a young squirrel, in the fall of the year, after he has lived for a 
time on the mast, or a rabbit well fattened in the fields, and broil it carefully over a bed of wood coals in the forest, delicately turning it and watching it, till the skin becomes brown and crisp and the tender pink flesh cracks apart slightly as it sizzles-and then, if it be properly prepared, if this juicy morsel is not the best thing you ever tasted, and fit food for kings or the gods-well, sir, then you are no epicure, and I will have none of you!

Richard Jefferies has forever immortalized country cooking in this unrivaled description of a leg of mutton roasted before an open fireplace, in his "Amaryllis at the Fair :"

"That day they had a leg of mutton-a special occasiona joint to be looked on reverently. . . . The meat was dark brown, as mutton should be, for if it is the least bit white it is sure to be poor; the grain was short, and ate like bread and butter, firm, and yet almost crumbling to the touch; it was full of juicy red gravy, and cut pleasantly, the knife went through it nicely; you can tell good meat directly you touch it with a knife. It, was cooked to a turn, and had been done at a wood fire on a hearth; no oven taste, no taint of coal gas or carbon; the pure flame of wood had browned it. : Such emanations as there may. be from burning logs are odorous of the woodland, of the sunshine, of the fields and fresh air; the wood simply gives out as it burns the sweetness it has imbibed through its leaves from the atmosphere which floats above grass and flowers. Essences of this odor, if they do penetrate the fibers of the meat, add to its flavor a delicate aroma. Grass-fed meat, cooked at a wood fire, for me."

"Better a dinner of herbs where love is, than a stalled ox and hatred therewith." The privilege of the 
wood hearth endears to our hearts the thoughts of home, as the dinner of herbs makes it more real to those who prepare and partake of it. Here, before cur rousing fire-as if still nomads a-wandering in some primeval paradise-here, we may take our ease in an unrestrained, unconventional, natural happiness: Robin

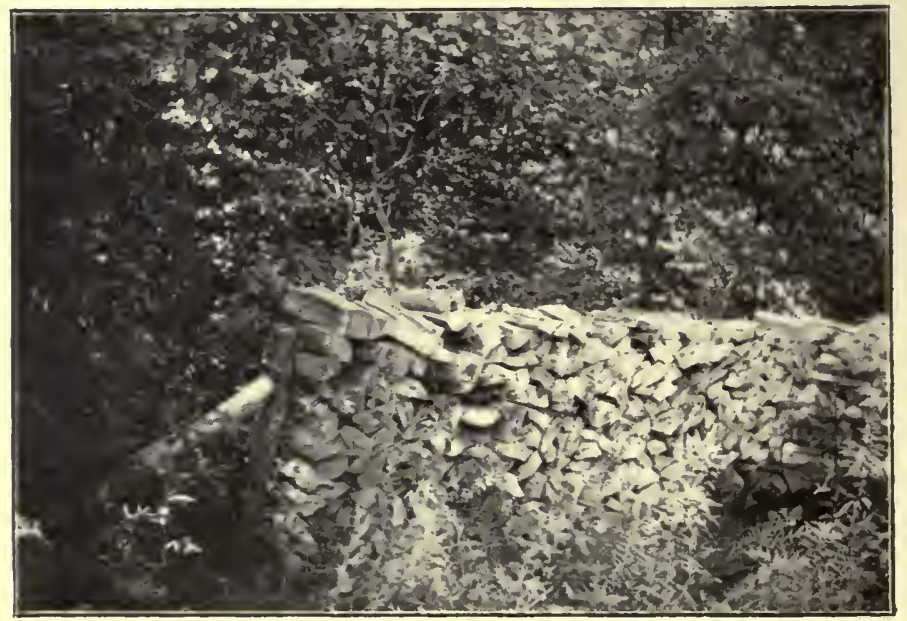

SPLIT WOOD RANKED UP IN THE WOODS.

Hood and his merry men again, roasting a haunch of venison, home from the chase, under the trees.

Each variety of wood, too, like each flower, has its own delicate and separate scent when burning, as the freshly cut logs have also when lying in the woods. It is no wonder that the perfume of the smoke is so delightful, formed, as it is, from all the influences of the woods, and the air, and the flowers and grass, absorbed and floated away now in beautiful wreaths. The aroma of the vapor from a wood fire is filled with all 
sorts of romance and poetic suggestion. When I see smoke issuing from a chimney, and can smell the fragrance from a wood fire, I always feel that I really am once more in the country. It is a perfume which one finds only there. It has the genuine flavor of the woods and meadows.

Whitman speaks of his enjoyment of this feature of the country upon one of his rambles near the Hudson ("Prose Works:" "Days at J. B's.-Turf FiresSpring Songs") :

"As I go along the roads I like to see the farmers' fires in patches, burning the dry brush, turf, debris. How the smoke crawls along, flat to the ground, slanting, slowly rising, reaching away, and at last dissipating! I like its acrid smell-whiffs just reaching me-welcomer than French perfume."

The smoke, therefore, as it comes rolling and puffing in clouds and fumes from the flue, and vanishes into nothingness finally in thin feathery shreds and whitish films, is always a symbol of home and has a human interest. Do you recall Thoreau's poem upon smoke, and what he says of it, in "Walden?"-

"When the villagers were lighting their fires beyond the horizon, I too gave notice to the various wild inhabitants of Walden vale, by a smoky streamer from my chimney, that I was awake.-

" Light-winged Smoke, Icarian bird,

Melting thy pinions in thy upward flight, Lark without song, the messenger of dawn, Circling above the hamlets as thy nest; Or else, departing dream, and shadowy form of midnight vision, gathering up thy skirts ; 
By night star-veiling, and by day

Darkening the light and blotting out the sun ;

Go thou my incense upward from this hearth,

And ask the gods to pardon this clear Mame."

Elsewhere, in his journals, he writes more lengthily of the ideal suggestiveness of smoke, as it is seen at a distance about a cottage or farmhouse. Cooper, too, I remember, in his novels, frequently speaks of the human significance and associations of smoke when it is observed through the forest. Why? Because it rises from the camp-fire or the hearthstone.

And then what does n't the wood fire suggest of the days spent in cutting the wood beneath the autumn leaves, with cant hook, and saw and ax, and maul and wedges! Occasionally we get a reminder of those days by a few ants seen crawling out from beneath the bark of a backlog-to perish, poor things, in the fire; and we recollect the times when we have discovered bees and wasps in the trees that we brought low. We remember the crash of the tree as it fell; and how, when split open, it disclosed an army of grubs and borers: finally to repose, piled in tiers, in the woodshed, seasoned and ripe for the dogs. Ah, I am cutting it again among the trees, and hauling it in to the woodshed in sled and wagon loads in winter. Often, in loading a lot of firewood which had been ranked up against a stump or a sapling, I have found a rabbit concealed in under the wood; and lizards have darted away, when those sticks closest to the ground were removed; and little wood mice would scatter in all directions at the stack's dismemberment. But men are of more value, after all, than many mice, and these "small deer" can 
find a home again in under the innumerable leaves, or beneath a stump, or in a hollow root. Poor little fellows! how they are in terror of a dog, and how cruelly a dog snaps them in his jaws and cracks their fragile little ribs! I have even had them crawl up on the outside of my trouser's leg in fear when my dog was after them, and their mute appeal has never failed of a right answer.

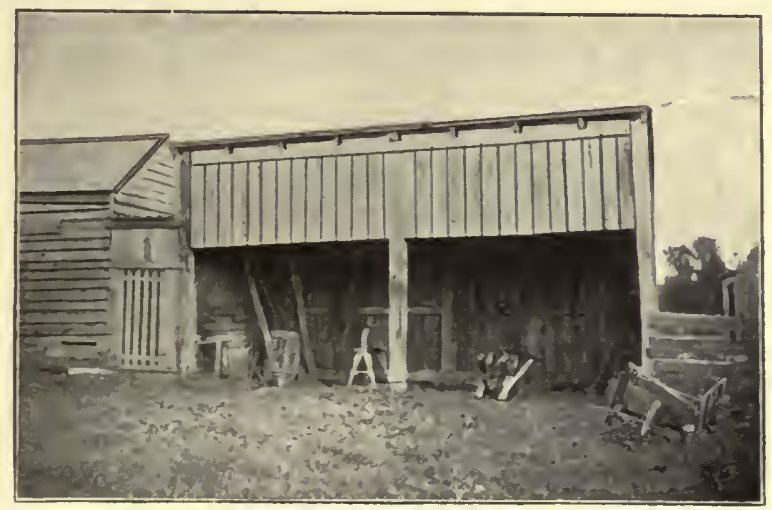

THE WOODSHED.

It used to be the custom in the early days to build some of the log cabins with fireplaces in them so large that a regular log, or section of an entire prostrate tree, could be used as a backlog. In that case there was a door at each end of the fireplace (which extended, practically, completely across one side of the cabin), and a horse would be driven in dragging the $\log$ by a chain; the chain would be unhooked, the horse would go out by the other door, and the great log 
would be rolled over back into the deep fireplace, where it would last for several days.

I have seen many open fireplaces in cabins in the South, built in irregularly of stones taken from the creek or gathered at the clearing, with their sooty corners jutting out every which way in a picturesque fashion into the flames, and with a great wide open hearth, large enough for a small whole log to enter. The chimneys were made of crossed sticks cemented together with mud-stack chimneys, as they are called. I have often sat beside them, and there have heard related stories of the great war between the States, fought so long ago, as it seems to us now, and have listened to the tales of slaves and slave-owners, with mayhap the barrel of an old army musket, or a bayonet, picked up or captured on some battlefield, as our poker and tongs.

I remember once being also in the study of an eminent college professor, whose glory it was that he had a large fireplace and an open wood fire. He had a very comfortable divan arranged in front of it, and a lamp convenient; and I suppose that a good many of the problems of earth and heaven were solved there before the logs. I recollect also the study of another professor, who, as a lover of books, could scarcely have found a more fitting environment in which to interpret the real spirit of literature than the atmosphere of his large open fireplace, with his setters stretched before it, in his beautiful old house of the Revolutionary days. It was, too, my good fortune to be one of a group of young men who once pursued a course in poetry in the library of another professor, 
before his cheerful wood fire. My mind goes back also to a few glimpses that I was privileged to take of the study of the president of a great university, where a wood fire burned on the hearth, beside the books; and, again, to a brief midnight visit to the spacious and magnificent library of another and most profound scholar, world-renowned indeed for his erudition, who rejoiced, apparently, even in his theology, in the inspiration of his lovely wood fire and in the comfort of having his easy-chair drawn close to it. (The hired man gave me the opportunity, with a lantern to guide us; and a weird, almost mystical, feeling it was that came upon me to be there, in the dimness, among the interminable tomes of the great dead.) But, of all my college memories, the one that I cherish perhaps most, or at least equally. with any of the others, is the thought of a delightful evening which I spent in the fellowship of a great philosopher, when, as we talked together through the hours before the logs and watched the glowing coals die away into the midnight embers, he spoke to me of God, and of the reality of truth, and of the exceeding beauty of life.

No one who has ever stood before the old-time, spacious fireplace at Mount Vernon, with its crane and trammels and all the cooking utensils, can have failed to feel a thrill in the experience. Why, here Washington lived! And this is the kind of fire he had! And so with all the other colonial mansions, when the forests were plenty-old andirons, old bellows, old tongs, old inglenooks. What an atmosphere of oldtime ways and old-time living - the very heart of the republic, even now, to my thinking! 
The old-fashioned fireplace is roomy, and one does not feel cramped, as he frequently does even in the better city residences. Few things are more delightful to the memory than late afternoons and evenings spent with a book before the crackling hearth in the twilight. ' $T$ is then we appreciate the value, in Cowper's lines, of

"Homeborn happiness,

Fireside employments, intimate delights,

And all the comforts that the lowly roof

Of undisturbed retirement and the hours

Of long uninterrupted evening know."

The fire is especially cheerful in cold weather, when the snow is swirling and drifting outside, and silting a little under the doorsill, or perhaps a flake or two falling down the great black chimney. Emerson speaks of it in "The Snow-Storm:"

"The sled and traveler stopped, the courier's feet

Delayed, all friends shut out, the housemates sit

Around the radiant fireplace, inclosed

In a tumultuous privacy of storm."

And again, in his "May-Day," he says:

Back to books and sheltered home,

And wood-fire flickering on the walls,

To hear, when, 'mid our talk and games,

Without the baffled north-wind calls."

There is a painting by David Neal (I have seen but the wood engravings of it), in which the artist has placed James Watt beside an old-fashioned fireplace, watching the steam come whistling from a kettle, as it hangs over the logs from a crane. Many a book, too, has been read in the firelight by tow-headed boy lying before it. 
How many fancies circle about the wood firethoughts of the squirrel twitch-ups and the quail traps, and of the halcyon days of long ago when as many as a dozen quail could be caught in a figure four, and of the many squirrel and quail and rabbit hunts; aye, and dreams, too, dreams of what might have been, and of what still may be, in the opportunities of life. But let Keats tell us of the mood in his "Fancy:"

"O sweet Fancy! let her loose;

Summer's joys are spoilt by use, And the enjoying of the Spring

Fades as does its blossoming;

Autumn's red-lipped fruitage too,

Blushing through the mist and dew,

Cloys with tasting. What do then ?

Sit thee by the ingle, when

The sear faggot blazes bright,

Spirit of a winter's night;

When the soundless earth is muffled,

And the caked snow is shuffled

From the plowboy's heavy shoon ;

When the Night doth meet the Noon

In a dark conspiracy

To banish Even from her sky.

Sit thee there. and send abroad

With a mind self-overaw'd,

Fancy high-commission'd :- send her!

She has vassals to attend her:

She will bring, in spit of frost,

Beauties that the earth hath lost;

She will bring thee, all together,

All delights of summer weather;

All the buds and bells of May,

From dewy sward or thorny spray ;

All the heaped Autumn's wealth.

With a still, mysterious stealth :

She will mix these pleasures up

Like three fit wines in a cup, 
And thou shalt quaff it:-thou shalt hear

Distant harvest carols clear;

Rustle of the reaped corn;

Sweet birds antheming the morn;

And, in the same moment-hark !

' $T$ ' is the early April lark,

Or the rooks, with busy caw,

Foraging for sticks and straw."

I believe, too, with Emerson, that the farmer has to encounter the same problems of life, while seated before the open wood fire on his hearth, that the philosopher meets with in his study, and reaches a solution perhaps just as satisfactory; that it requires the same struggle to do so, and the solving has with each the same ultimate and fundamental truth and good in it: just as the private soldier can know as much of courage and patriotism and true love of country as the general.

There is yet one thing further I will say. I have made fires of poplar and tacamahac on the prairies of Minnesota for my noontide; I have heard the bacon sizzle over a roaring blaze of pine bark in a lone hunter's cabin far back on Lookout Mountain; I have warmed myself by the flames of the cottonwood along the Cumberland and Ohio; I have broiled a rabbit for my meal over the coals of the loblolly pine, far away in central Arkansas; I have gazed across toward the Catskills beside a fire of spruce in the Berkshires; I have roasted venison for my lunch before a fiery mass of birch deep in the forests of the Adirondacks; I have cooked pickerel on a grating of stones heated by flames of maple on the shores of Lake Superior; I have watched the flickering blue flare of a driftwood fire along the beach of the Atlantic; and I have found a 
companion for myself in the light of beech and oak and hickory in many and many a woody dingle, and perchance have broiled a squirrel or a bird for breakfast: but never, and nowhere else, have I enjoyed the real and genuine and lasting comfort of a wood fire so thoroughly as right back here at the old homestead, before the huge old mossy backlog and flaming foresticks. Ah, how the delight of it lingers-and lingers!

Homer tells us, in a realistic picture, in the "Odyssey," that, when Hermes reached Calypso's cave, "on the hearth was a great fire burning, and from afar through the isles was smelt the fragrance of cleft cedar blazing, and of sandal wood." Theocritus, too, that old Greek lover of the open air and the best things life has for us, loved the charm of the wood fire. It was beside such a hearth that Menalcas, the shepherd, reclined, in his song in the ninth idyl, with fleeces from his ewes and goats beneath him, in his cave:

"In the fire of oak-faggots puddings are hissing-hot, and dry beech-nuts roast therein, in the wintry weather, and, truly, for the winter season I care not even so much as a toothless man does for walnuts, when rich pottage is beside him."

And for this, his song, he received from Ætna the gift of a horn made of a spiral shell.

Esop saw fit to make the hearth the scene of one of his fables, in which a countryman finds a freezing snake and brings it in before the fire; upon which the snake, at its recovery, attacks the villager's wife and children, and is summarily dispatched for its ingrati- 
tude. Cinderella, too, in the fairy tale, busies herself before the hearth.

Shakespeare evidently knew of the wood fire, and we perhaps get hints of his own poaching experiences in what few glimpses we have from him of the log fire of those days. The song of Winter, in "Love's Labour 's Lost," is an example in point:

"When icicles hang by the wall,

And Dick the shepherd blows his nail,

And Tom bears logs into the hall,

And milk comes frozen home in pail,

When blood is nipp'd and ways be foul,

Then nightly sings the staring owl,

Tu-whoo;

Tu-whit, tu-whoo, a merry note,

While greasy Joan doth keel the pot."

And again, in "Romeo and Juliet," Capulet orders:

" Sirrah, fetch drier logs;

Call Peter, he will show thee where they are."

Implying, one might think, that there was a lot of them heaped up ready for the fireplace. Further, in "The Tempest," when Caliban says that he 'll no longer "fetch in firing" for his master, Prospero requires it of Ferdinand; and thereby hangs the tale, in one of the prettiest of love matches:

"Enter Ferdinand, bearing a log.

Ferdinand.- ' There be some sports are painful, and their labor Delight in them sets off:

I must remove

Some thousands of these logs, and pile them up, Upon a sore injunction.' 
Pray, set it down, and rest you : when this burns,

' $T$ will weep for having wearied you.

If you 'll sit down,

I 'll bear your logs the while. Pray, give me that;

I 'll carry it to the pile.' . . .

Ferdinand.-

'Hear my soul speak :

The very instant that I saw you, did

My heart fly to your service: there resides,

To make me slave to it; and for your sake

Am I this patient log-man.',"

And finally, in "All's Well that Ends Well," the clown says to the Lord Lafeu, "I am a woodland fellow, sir, that always loved a great fire;" such a fire, one might infer, as is a common sight in our wooded America.

It was beside a neatherd's hearth, according to the story, that Alfred the Great had the mortification of letting his cakes burn. I think, too, of the spacious hall in the mansion of Cedric the Saxon, with its roaring, yawning fireplaces, as pictured in "Ivanhoe," and of the other wild hearths that Scott has described. Leigh Hunt has a pleasant essay entitled "A Day by the Fire," but I have always thought it would have been better if his had been an open wood hearth instead of a grate of coal. It is beside a coal fire, however, that Dickens places his cricket, with the kettle above it, and tells us in its chirpings that the reason the hearth is so dear and sweet is because it is the symbol of home and happiness. "To have a cricket on the hearth is the luckiest thing in the world."

That is a pretty picture which Burns drew in "The Cotter's Saturday Night," when the laborer returns 
after the toil of the week to his cottage at the close of day.-

"At length his lonely cot appears in view,

Beneath the shelter of an aged tree;

'Th' expectant wee things, todlin', stacher thro'

'To meet their dad wi' flichterin' noise and glee.

His wee bit ingle blinkin' bonnilie,

His clean hearth-stane, his thriftie wifie's smile,

The lisping infant prattling on his knee,

Does a' his weary, carking cares beguile,

An' makes him quite forget his labor and his toil."

And, later,

"The cheerful' supper done, wi' serious face

They, round the ingle, form a circle wide;

The sire turns o'er, wi' patriarchal grace,

The big $\mathrm{Ha}^{\prime}$-Bible, ance his father's pride:"

and hymns are sung, and the Scriptures read, and prayers are offered, in the firelight.

It was around the logs on winter nights, according to Macaulay's "Lays of Ancient Rome," that the custom was, in the old Roman days, to relate the story of Horatius and his brave defense of the bridge. The hearth was consecrated to Vesta, and the Lares and Penates were the household gods.

The Yule log was a great institution in old England. It was a huge affair, sometimes a full, unsplit trunk of a tree, brought to the door by horses, or a large tree-root whole; and it was always lit from a chunk of the old log, saved from last year's burning and kept carefully preserved for that purpose. A great deal of the romance attached to the open fireplace clusters about the Yule log and its association of the mistletoe and Christmas-tide. Says old Drayton: 
"And at each pause they kiss; was never seen such rule In any place but here, at bonfire, or at Yule."

Tennyson mentions it in his line,

"The Yule-log sparkled keen with frost,"

and gives this picture of the Christmas festivities, in "In Memoriam:"

"Again at Christmas did we weave

The holly round the Christmas hearth;

The silent snow possess'd the earth,

And calmly fell our Christmas-eve."

Washington Irving was naturally attracted by such a scene, and writes of the $\log$ in his "Sketch-Book." Lowell, too, in "The Vision of Sir Launfal," has left a charming description:

"Within the hall are song and laughter,

The cheeks of Christmas grow red and jolly,

And sprouting is every corbel and rafter

With lightsome green of ivy and holly;

Through the deep gulf of the chimney wide,

Wallows the Yule-log's roaring tide;

The broad flame-pennons droop and flap

And belly and tug as a flag in the wind;

Like a locust shrills the imprisoned sap,

Hunted to death in its galleries blind;

And swift little troops of silent sparks,

Now pausing, now scattering away as in fear,

Go threading the soot-forest's tangled darks

Like herds of startled deer."

And, again, our American poetess, Celia Thaxter, in her poem "The Yule Log," has, among others perhaps its equal, this beautiful stanza:

"Come, share the Yule-log's glorious heat!

For many a year the grand old tree

Stood garnering up the sunshine sweet,

To keep for our festivity." 
But, as I sit before the logs, I am reminded especially of that delightful book, of our own country, which most men have read somewhere in their early twenties, or before it, "The Reveries of a Bachelor," by Ik Marvel, for it was beside such a fire, you remember, that the first of the reveries was dreamed; and in "Dream Life," too, there is mention of the open wood hearth.

Indeed, there have been a few books named from the fire-Lowell's "Fireside Studies," Mabie's "My Study Fire," Gray's "Camp-fire Musings." But Charles Dudley Warner's "Backlog Studies" is the classic of the old-time fireplace. His books are always delightful, and to quote from it with any satisfaction would be to give it all. Warner deprecated the loss of the open wood fire of our ancestors, and defended it with very zealous partisanship. He says that the supreme achievement of woman, and the most convincing evidence of her claims to the title of housewife, is for her to maintain the supremacy of the open wood fire.

It is to our own American Whittier, also, that we are indebted for what are, so far as I have read or can recall, perhaps the best lines written upon the oldfashiened fireplace of the forefathers, in this familiar picture, in his beautiful idyl "Snow-Bound:"

\footnotetext{
"As night drew on, and, from the crest Of wooded knolls that ridged the west, The sun, a snow-blown traveler, sank From sight beneath the smothering bank, We piled, with care, our nightly stack Of wood against the chimney-back,The oaken log, green, huge, and thick, And on its top the stout back-stick; The knotty fore-stick laid apart, And filled between with curious art
} 
The ragged brush; then, hovering near, We watched the first red blaze appear, Heard the sharp crackle, caught the gleam On whitewashed wall and sagging beam, Until the old, rude-furnished room Burst, flower-like, into rosy bloom;

Shut in from all the world without, We sat the clean-winged hearth about, Content to let the north-wind roar In baffled rage at pane and door, While the red logs before us beat The frost-line back with tropic heat; And ever, when a louder blast Shook beam and rafter as it passed, The merrier up its roaring draught The great throat of the chimney laughed;

The house-dog on his paws outspread Laid to the fire his drowsy head, The cat's dark silhouette on the wall A couchant tiger's seemed to fall; And, for the winter fireside meet, Between the andirons' straddling feet The mug of cider simmered slow, The apples sputtered in a row, And, close at hand, the basket stood With nuts from brown October's wood."

\section{Ah, Whittier knew that kind of a fire!}

From one of our living American poets, too, $\mathrm{Mr}$. Lloyd Mifflin, I shall select the following very beautiful and flowing sonnet, entitled "Upon the Hearth" (from "At the Gates of Song"), as expressing better than any of us can do the real poetic significance of the blazing logs and the old-time open fireplace:

"A tree will prove a blessing all life long;

From birth to death it brings us naught but good;

Its shade will make a pleasant solitude,

For one who lies and dreams the grass among;

5 What golden globes upon its limbs are hung 
In summer; and when dead, its burning wood Will foster sweetness in the poet's mood, And hum upon his hearth, and help his song. Its death is like the day's, for still it throws Its roseate light lingering around our rooms; As slow the fire its last of life consumes, It sinks to embers like to sunset snows, And dying, even in its ashes, glows

With bright remembrance of its spring-time blooms."

The open hearth, of course, suggests the camp-fire of out-doors. Dr. W. C. Gray and Mr. John Burroughs both think-and is it a mere fancy? - that we have carried the wood fire indoors with us from our primeval, open-air life of ages past. Mr. Burroughs says that the "primitive man" in him wakes up at once at the smell of smoke, "and all his old love of fire, and dependence upon it, in the camp or the cave, comes freshly to mind." Mr. Bradford Torrey, too, believes that, since we "have not always lived in houses," our feeling of attraction for a fire "is but part of an ancestral inheritance. We have come by it honestly, as the phrase is." Nor, as we, in our time, with our fire in the woods, look and observe the flames dart heavenward in aspiration, can we but rejoice that there have beeñ at least some fire-worshipers among the pagan, for it brought them to the beginnings of mystery and of adoration.

The camp-fire, of course, brings instinctively to mind the curl of smoke from wigwam or tepee, and is the symbol of the life of the plains-the council, the pipe of peace, the feast of buffalo and venison-in the native home of the American Indian. I bethink me also of the countless camp-fires of the armies of the earth, in the long history of war; and no man who 
has ever bivouacked as a soldier but will gladly journey back again on the march to watch once more on the battlefields of memory.

The camp-fires of literature are many. They began with Abel and the sacrifice. And in the Bible story, too, are other wood fires: Sarah and her cakes; Abraham and Isaac; the roasting of the Passover; Jehoiakim the king before the hearth. Peter it was who warmed himself in indolence before a fire while his Lord was buffeted; but it was the same impulsive Peter who was the first to reach the land when the Master called the fishermen to the shore of Galilee, and "they saw a fire of coals there, and fish laid thereon, and bread"- and Henry van Dyke says that he would rather have been at that camp-fire than at any other in history.

Homer and Virgil make frequent mention of the camp-fire, and the roasting thereon of venison and the flesh of bulls and goats, pierced through with spits. Theocritus also loved it, as well as the domestic hearth.

George Borrow, in his peculiarly wild and adventurous gypsy tales, has much to say of the open fire beside his tent; confessing, in "Lavengro," in a most singular and pathetic love story, that it was in Mumper's Dingle, beside the camp-fire of their gypsy tabernacle, that he wooed, and lost, the fine-natured, truehearted Isopel Berners. In few passages, also, of Borrow's books is his real character revealed so delightfully as in these apparently chance remarks with the Welsh preacher's wife in their encampment by the oaks under the stars:

"'Excuse me, young man [she asked], but do you know anything of God?' 
" 'Very little [he replied], but I should say he must be a wondrous strong person, if he made all those big bright things up above there, to say nothing of the ground on which we stand, which bears beings like these oaks, each of which is fifty times as strong as myself, and will last fifty times as long.' "

Kinglake also, in his "Eothen," relates a romantic experience of his making a bivouac near the Jordan.

Thoreau enjoyed a camp-fire as few ever did. I recollect especially his accounts of camp-fires in "The Maine Woods," and this characteristic passage in particular:

"It was interesting, when awakenec at midnight, to watch the grotesque and fiend-like forms and motions of some one of the party, who, not being able to sleep, had got up silently to arouse the fire, and add fresh fuel, for a change; now stealthily lugging a dead tree from out the dark, and heaving it on, now stirring up the embers with his fork, or tiptoeing about to observe the stars, watched, perchance, by half the prostrate party in breathless silence; so much the more intense because they were awake, while each supposed his neighbor sound asleep."

Mr. Richard Watson Gilder has sung of the campfire, and its light upon the trees in the forest, in "The Voice of the Pine:"

"' $\mathrm{T}$ is night upon the lake. Our bed of boughs Is built where, high above, the pine tree soughs. ' $T$ is stiil-and yet what woody noise: loom Against the background of the silent gloom!

"Long had we lain beside our pine-wood fire, From things of sport our talk had risen higher. How frank and intimate the words of men When tented lonely in some forest glen! 
"And as we talked, the intense and resinous fire Lit up the towering boles, till nigh and nigher They gather round, a ghostly company, Like beasts who seek to know what men may be."

That was quite a fire which Shingebis, the diver, had in his lodge, in Longfellow's "Hiawatha," and I question whether it has ever been equaled:

\footnotetext{
"Four great logs had he for fire-wood, One for each moon of the winter."
}

Dr. W. C. Gray avers that he was able to hear the music of the spheres beside his camp-fire in the Northern woods; and elsewhere in his "Musings by Camp-fire and Wayside" has that stanch old lover of the wild led us into many an attractive train of moralizings by the firelight. Rowland E. Robinson has written pleasantly of his thoughts beside it; Mr. John Burroughs is a warm enthusiast in its mellowing light; Mr. John Muir has told us of his camp-fires in the Sierras; and quite recently, also, Mr. Stewart Edward White, in "The Forest," has delighted many with his camp-fire descriptions.

Mr. Henry van Dyke, however, is its most loyal defender, his sketch on "The Open Fire," in "Fisherman's Luck," being as readable a paper upon the subject as one could wish. Mr. van Dyke (I may remark, in passing) speaks of using his lunch paper to start his camp-fire with, but, in making our fires, in boyhood days, we used to scorn the use of paper, as belonging more to the usages of civilization, and so always started ours with leaves and twigs, in true woodcraft style. We wanted to be more primitive and savage, and to lie at the side of our "dim religious light" with some sort of sense of fatherhood. 'T was the old wild in- 
stinct cropping out in us, you know; and our greatest regret was that we were always unable to kindle a blaze by twirling one stick against another, which would thus have obviated entirely the obnoxious necessity of matches. But then, anyway, savages did not need a fire so much as we.

But to return to our own hearth. Here centered the life of grandfather's family. Around it they lived, and here the boys and girls were brought up. It was the home fire. Consequently, to one who has lived in such an atmosphere, and especially to one whose whole early life was surrounded with the influences of the wood fire on the hearth, and whose memories are all of that, nothing stands for the real meaning of home and family quite so well as does the old-time open wood fireplace. Nothing can take its place-no coal grate, or stove, or registers, or steam heaters-nothing has the same pioneer-like atmosphere.

Yes, my heart lies back among the old quail traps and rabbit twitch-ups. I love the simple ways of the open wood fire of long ago. All the conventional, modernized life is gone as I sit before it, all gone away into the smoke of the chimney. But it comes back again, and will not leave me; and the glow of the backlog dies away with my thoughts, just as the older life is passing, never to be produced or lived again-nay, has almost vanished now even from our memories.

The backlog topples over. Thut! A spark or two ascend the chimney. There is a last pale flicker. The old fire is out. . . . Let us bank it up for the night. 


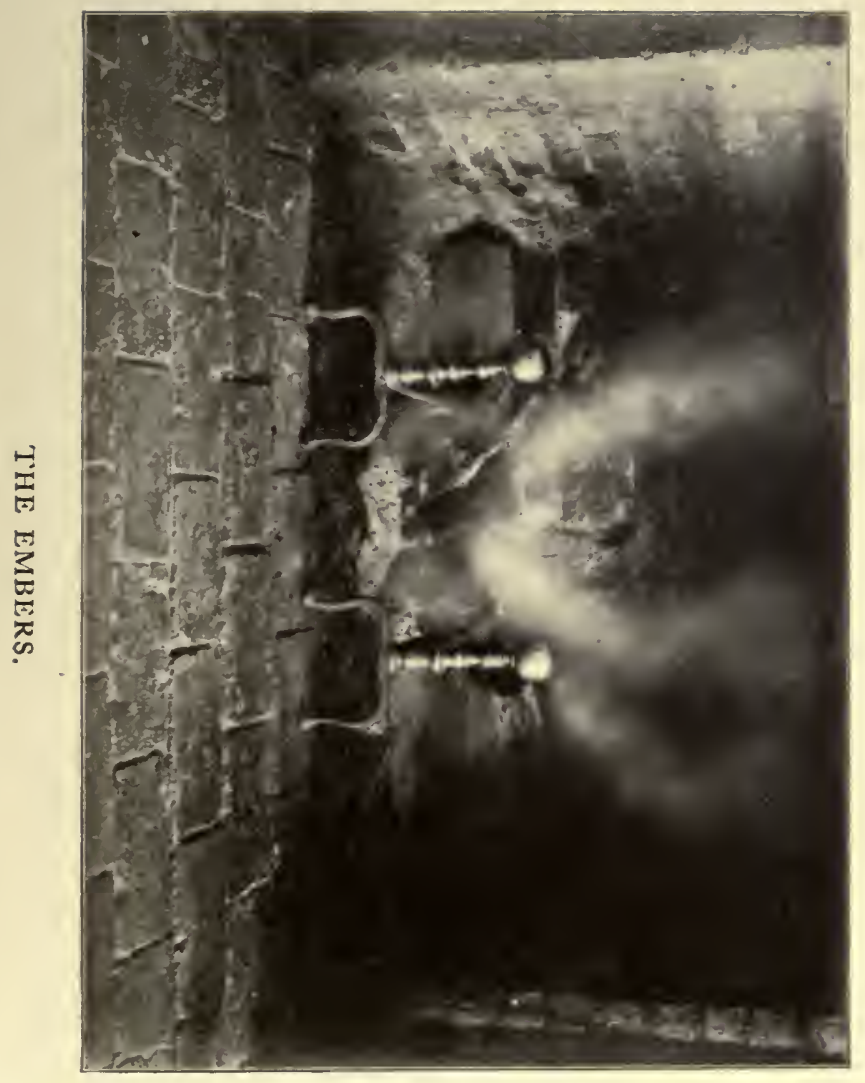





\section{THE OLD MUZZLE-LOADING RIFLE.}

"There could be no greater pleasure to me than to wander with a matchlock through one of the great forests or wild tracts that still remain in England. . . The weapon itself, whether matchlock, wheel-lock, or even a cross-bow, would be a delight.

"An imperfect weapon-yes: but the imperfect weapon would accord with the great oaks, the beech trees full of knot-holes, the tall fern, the silerce and the solitude. The chase would become a real chase: not, as now, a foregone conclusion. And there would be time for pondering and dreaming."

-Richard Jefferies.

THERE used to be (and still is) an old muzzleloading rifle about the farm, hanging generally in the lobby, which is just around the corner from the fireplace, on two forks of saplings that had been nailed against the wall as hooks to support it. It had curious curvatures on the stock, on which to rest the chin and cheek, and the butt was curved so as exactly to fit the shoulder. Its barrel was octagonal in shape, and full-stocked-that is, with wood from the stock extending all the way beneath the barrel up to the muzzle-and was very long, the full length

THE OLD MUZZLELOADER.

from butt to muzzle being fifty-eight inches; thus making the gun, stock and all, as tall as the tallest boy thereabouts, almost. It had a very long ramrod, too, that slipped down into the stock in a groove under the barrel, and we used to wonder how we could ever replace it, if it got broken. The caliber was about .38. The shoulder plate and trigger guard were of brass, and there was a silver shield-like plate on the small of the stock for the owner's name. 
There was an old powder-horn hanging there also, which belonged to the rifle. It we were allowed to take when out with the shotgun-that, too, a muzzle-loader - to carry our powder in. The shot we generally took in a bottle, the old shot belt having been lost, though we still had the brass shot measure that was formerly attached to it. Besides these, three other rifles were in the lobby. One was a THE HENRY. .56 caliber, an old army gun, which had doubtless been used in the war, and which had killed deer also; another was an old Henry .44 caliber rim fire, with all mountings of brass, and it had also done duty with reference to deer: and the third was a small .22 Flobert, used to annihilate sparrows or rats, or occasionally to kill a chicken that was refractory and refused to be caught. There were also, home from the war, and now reposing peacefully on nails and pegs, an old army holster and a brace of Colt's muzzle-loading pistols-curiously wrought on the revolving chamber with odd engravings illustrating the value of such firearms in case of highway robbery-and a cavalryman's helmet, with plume still waving. Quaint old lobby!

The old muzzle-loading rille had belonged to grandfather, and had been shot by all his sons and by almost all their sons, but had become so rusty from disuse that to shoot it again some thought the rifling would have to be bored out once more. But we did n't care for that, and at spare moments at noon or in the evenings we would stealthily take the old gun down and out onto the porch, and, raising it slowly and steadily, 
would pull the trigger. The trigger was a hair trigger, and the point was to get the aim accurate at some familiar object of the barnyard or some tree in the woods, and then pull at once, while on the level. But our powder was smokeless, and our bullets were never dug out of the trees we shot into. Yet it is curious that there were few things in the immediate vicinity of the old homestead that escaped being killed or stricken down by our deadly aim. We would deliberately point at the best rooster on the farm and fire, and then coolly say, as the innocent fowl kept on pecking, "There, he 's done for." I have even known us to fire at the horses or the pigs and cattle, and occasionally a buggy or an unoffending farm wagon on the turnpike beyond was the object of our marksmanship. "Yes, I think I hit him," we would say. We never missed with that old gun. It was a heavy old gun, and it took all our strength in younger days, and not much less in maturer age, to lift it to a level and maintain it there. Generally we sought a rest against a porch pillar or held it muzzle-upward to the sky, so that the weight came upon our shoulders, and then proved experts with swallows and buzzards.

The old muzzle-loader, with its cap and ball, has had its day. Like the flint-lock, it is now but a relic, and has been replaced by the better rapid-firing and repeating breech-loading guns of all sorts. But the thought of it lingers lovingly with many people, for it was the association of their childhood, and they first learned the art of "drawing a bead" from its long, octagonal barrel and good sights. It brings back to 
the memory the many, many squirrel hunts of years ago, and is the symbol of all that is picturesque and pioneer-like and romantic in the past.

The boys of late have taken the old rifle down and soaked it in coal-oil and cleaned it thoroughly, and have got out the old bullet mold and made a lot of bullets; and it again does duty, they tell me, and shoots pretty nearly where you want it to, although, like a veteran, it is old and tottering and outnumbered. I have not heard of many of the wild creatures of the woods losing their lives from it in the hands of its present marksmen, but then that is not the fault of the old rifle. It is ready still for the hand that knows its cunning.

Yes! let us take down the old rifle and be always among the trees. Let us seek contentment in the seclusion and wildness of the forest, and let us ever keep alive in us the old hunting instinct, which in youth would rise up in our hearts at the first whiff of autumn, and which in old age will bring back the days of youth; and, with rifle on shoulder and powder-horn slung at our sides, let us seek again the old perfect life which still lurks somewhere in the great woods, and in the beautiful eyes of the doe and gray squirrel, and in the mystery and romance about the camp-fire.

Thoughts of the old times come back upon me in a flood of vaguest suggestion and sadness-thoughts of grandfather and grandmother, of the old-fashioned sugar camps, and of the great fields of wheat and the old reaping sickles; and I seem to live again in the past-the past, with its distaff and spindle, its home- 
spun, its pioneer-like independence and adventure and simplicity of life. I again shoulder the old muzzleloader and shoot a brace of squirrels before breakfast.

The older generation, tottering and wrinkled, is passing into a loving remembrance and is giving way to the new. The past, with its inimitably beautiful romance and its things of pathos and love, has given place in a large measure, except in memory, to the present, with its energy, glowing life, hopes, and its own romance and poetry-that, too, soon to be a tale and perhaps to be forgotten. The hills in the distance, as seen from the old homestead, seem to me in their sunset glory to be the symbol of the great West, the West that was filled with romance and adventure, and of which we all dreamed, and for which we longed, in childhood. A good deal of the old woods has been cleared away now, and the green hills beyond can be seen more plainly. The pioneer has left the old homestead, and has gone far beyond into the regions of the prairie and the great forest; and with him the older, aye, and perhaps the better, because the more simple, life-with all its ennobling and precious and enduring associations, still so dear to many hearts - has gone now forever, never to return, brushed aside like a cobweb by the relentless onward march of progress. But the memory of it clings. and will linger and cling through the years, for from such beginnings sprang the bone and sinew of the nation. 


\section{THE BARN.}

"An old barn is near: and the flocks and the poultry seem to enjoy an amount of comfort which we might look for in vain, in the vicinity of a more ornate dwelling-house."

-Wilson Flagg.

"And she wrapped Him in swaddling clothes, and

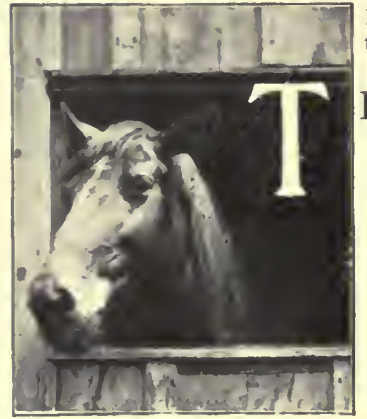

OLD DOLLIE. laid Him in a manger, because there was no room for them in the inn."

-St. Luke.

HE barn is not far from the homestead, thirty steps or so beyond the trough where the cows and horses drink; and the trough is near the well. It is quite a large building, well constructed of great hewn timbers; and it is an old structure, covered with the initials of two or three generations. The immense beams in its framework came from the woods, and one can still see the score marks of the ax, made originally in chopping in along the logs, to facilitate the hewing off of the big posts and slabs with the broadax, and thus, after all, to assist the laborer in his work. To build a barn served two purposes in those days, for to get out logs helped to clear the land as well as to erect a shelter for the stock and the hay. The bark still clings to some of the beams and rafters. The weatherboarding is of pine, from the State of New York, flatboated down the Ohio from Pittsburg, and costing, in those days, but eight dollars a thousand. It still protects and preserves the great interior from the storms. 


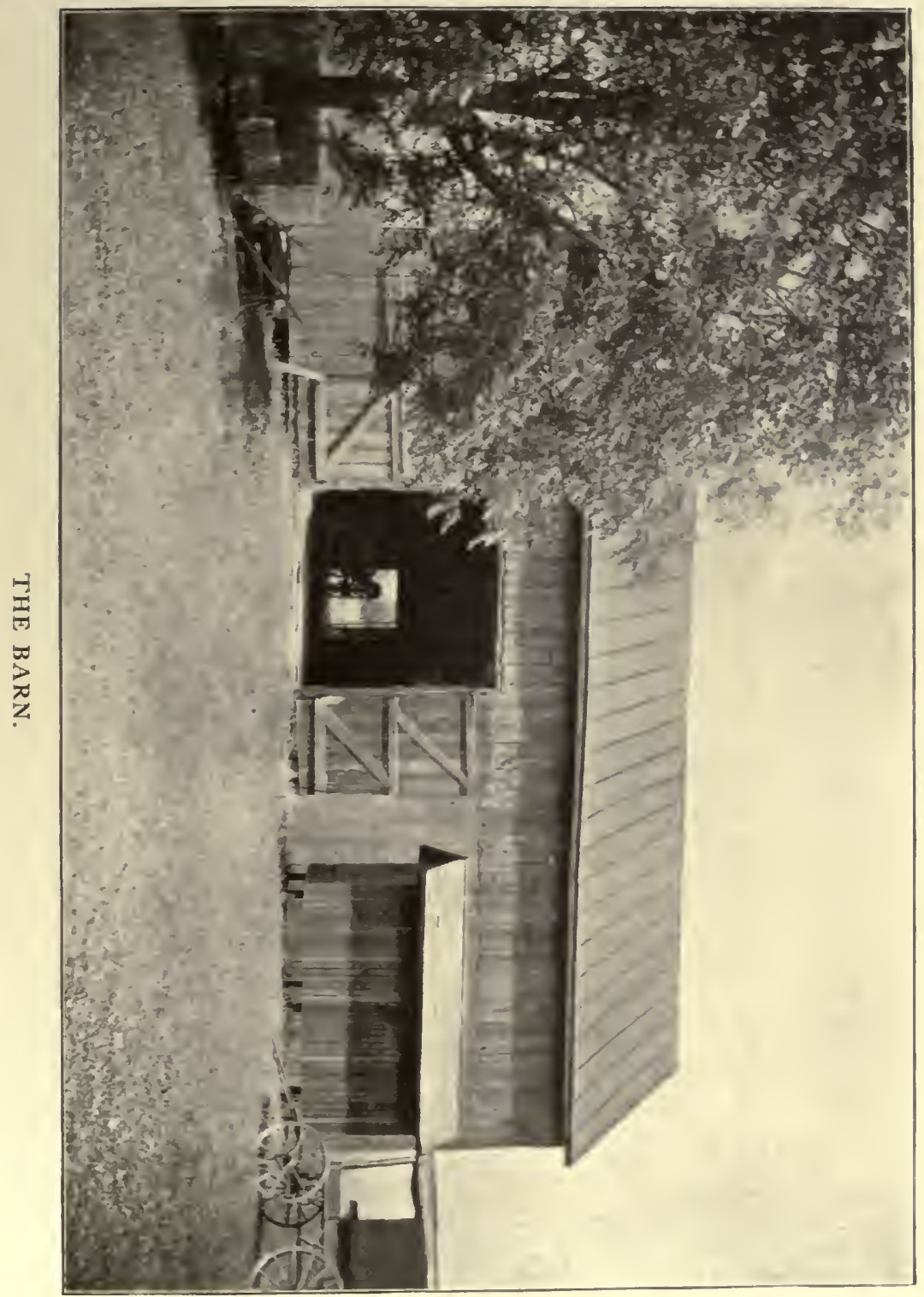



It was the custom of the neighbors to assemble and help a settler in the building of his barn; yet even then it was quite a task in pioneer days to put up the big beams, and a dangerous one, for the beams might fall. It took an even hundred men to do the work for grandfather. That was a "barn raising" worthy the name. Pot-pies after pot-pies-pot-pies galore for the menwere boiled out in the open in a big iron kettle, and innumerable biscuits and loaves of bread, and apple and mince pies, and what not; for a "barn raising," like a "husking bee," along with the fun, meant plenty of hard work and a commensurate amount of good things to eat. And when, toward evening, the barn was all done and the men were resting, grandfather stood on the very crest of the ridge-pole and threw the bottle that christened it.

The barn, especially in harvest, is always filled, sometimes with clover and timothy and rustling fodder, or, again, bursting with yellow wheat and oats just garnered, or stored with bins of potatoes and pumpkins in their season. Wisps of hay and grain, and straw and crackling corn leaves, hang from the mows in straggling bunches about the beams and rafters. It is on its broad floor, with doors flung wide, that the "husking bees" of former days took place, when the neighborhood would drop in for a frolic; and in these later times it is still the scene of threshing, either with the burly, roaring machine, which soon has a heap of the golden grains pouring upon the boards and a straw stack rapidly mounting behind the barn, whither its long elevator extends through the wide open doors, while the sheaves are thrown from the lofts above; or 
perhaps with horses, who patiently tread round and round upon the bundles, the grain and chaff from which, left after the straw has been raked off, are then run through an old-time fanning mill, and the wheat thus winnowed from the refuse; or, possibly, the beating is done in the primitive way with a flail at odd times through the winter, and marks of the swipple are to be seen on the boards. The corn-crib, stuffed with the yellow ears, is just outside the barn.

Instead of the dense woods which formerly stood back of it, all is open, tillable land, an extent of many miles; and the view that we have from its open doors, a long, peaceful stretch of country, out across the rolling hills and far beyond the Miami, is one that is not often afforded. Barn swallows dart in and out of the great doors, and their nests of mud and straw are plastered against the roof and rafters. Chickens peck about for chance bits of grain, and the hens lay their eggs beneath the mangers or stow them away in dark nests hollowed out in the mows, concealed amid the hay or straw.

I spoke of the initials. Two generations, at least, have left their marks upon it, and possibly three, or even four, so far as I know. It has always been such a repository, and the whole barn is to-day a veritable mosaic of letters and dates. We can find them inside and outside, on the doors, on the weather-boarding (these are getting a little faint now, being so old and exposed to the storms), on the rafters and beams (dug into the hard oak with heroic perseverance, with a barrel to stand on), on the big supporting posts, on the feed box, on the manger, and then again spreading to the barnyard, and finally on the water trough out by the 


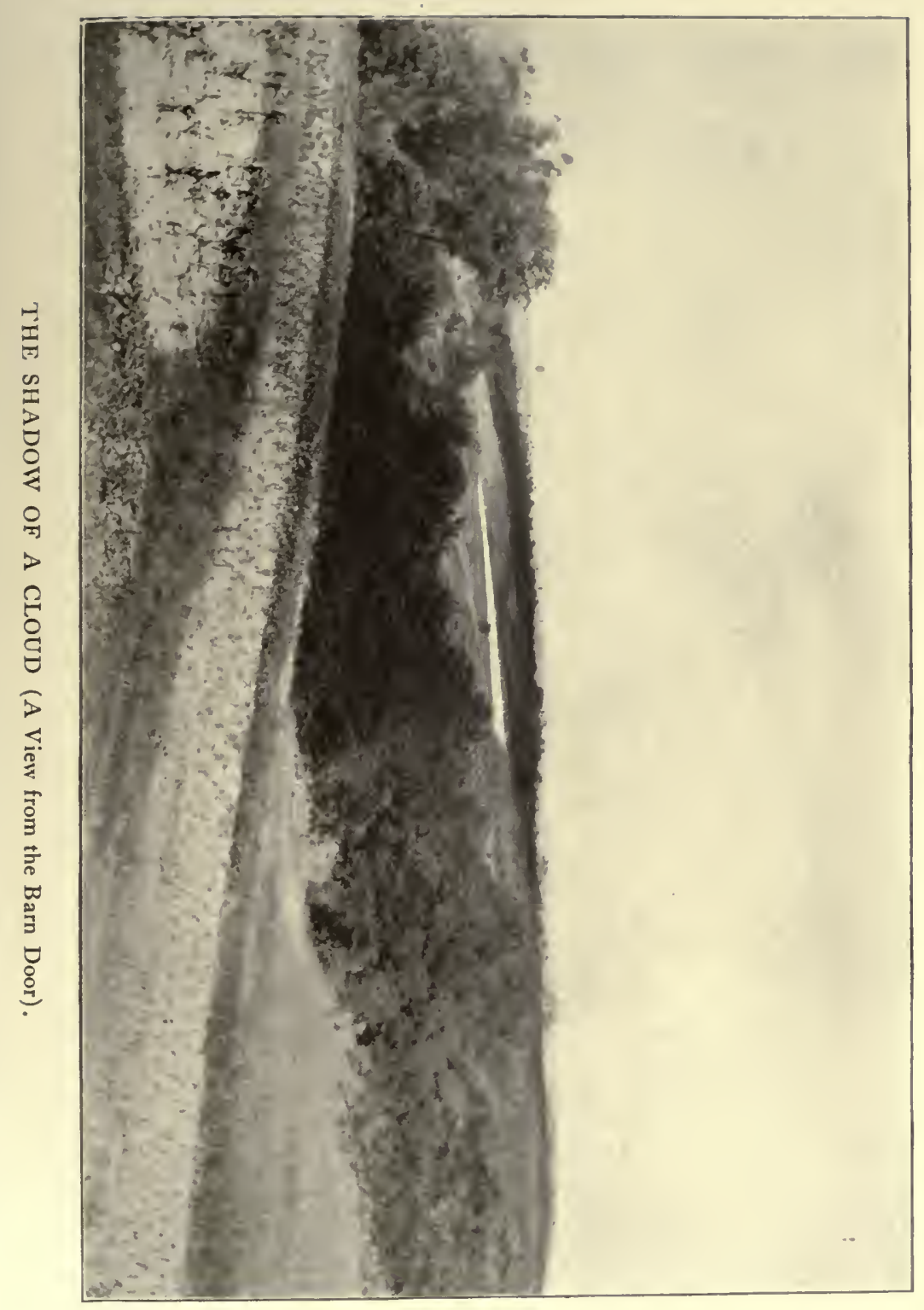



well. I remember once getting on top of the big straw stack back of the barn after threshing time, and scrambling up the long, sloping, mossy roof, and there carving my initials upon the shingles, for the enlightenment of balloonists and other aeronauts and of the heavens generally; but I do not suppose many ever saw them, for we had to climb up on a short ladder to reach the roof from the stack, and then afterwards we jumped off into the straw. I wonder if the men ever noticed them who tore the shingles off when they put on the new tin roof some years ago. I shall never forget the look of astonishment and appalling fear upon the faces of my aunts, who happened to be looking out of the doorway of the homestead just at the time we peered above the ridge-pole of the barn, while at our labors, to see the surrounding country, and who therefore at once saw us, much to their dire consternation. We, however, immediately ducked our heads, and when we again ventured to peek over, they had disappeared, to our great relief.

At a short distance west of the homestead (the barn is to the north) stands the carriage house, filled with many a curious relic of the past, and the place for the cider press and the great sugar kettles. Below it a few paces are the cow house and the pig pen; the former of these the daily scene of a tug at the udders, and the latter the annual scene of what Whitman calls "the plenteous winterwork of pork-packing," which, however, to my thinking, is more work than poetry. Close to the corner of the homestead, to the south, near the kitchen, is the smokehouse, covered with great waving plumes of trumpet-vine, which has grown up about it. Just west of it, and adjoining, is 
the open woodshed; and beyond that a little, across to the south from the carriage house, is the chicken yard, where, in the fruit season, the unhappy fowls must repose with clipped wings, and take their dust baths beneath the shade of sunflowers, whose seeds later on they will devour with the greatest relish.

The smokehouse once a year is the place for smoking the hams and bacons, when films and threads of white slowly issue from every crack and fissure between the boards and shingles, so that it looks from a distance as if the structure were on fire. The blaze beneath, the hanging hams, which are suspended from hooks nailed on the cross-beams, is generally made of green hickory and corncobs, and these give a sort of tang to the taste. It is sometimes also the repository of the big camp kettles, when unused, during the year.

The woodshed is filled with all the store of fuel for

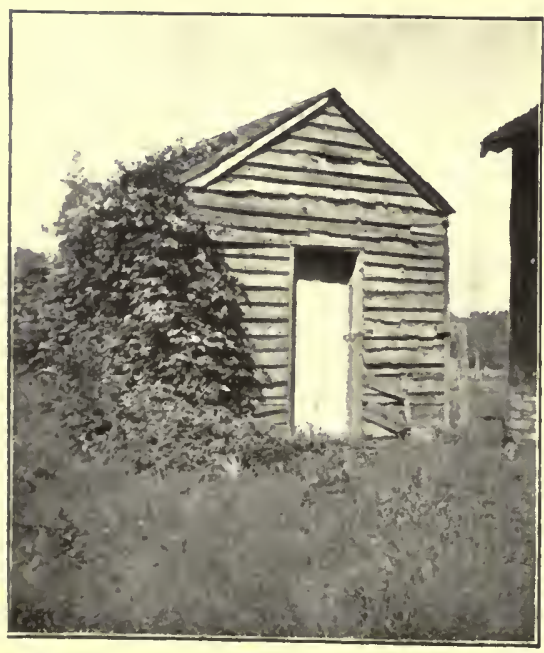
the stove and fireplacegreat backlogs of beech and maple, foresticks of these also, and of hickory, apple, ash, and wood of every description gathered about the farm. Above the tiers of wood, on a framework of boards, are piled the hundred or more buckets of the sugar camp. Here, too, in a corner, is a barrel of sour milk and other delicacies for the hogs.

The carriage house shel-

THE SMOKEHOUSE, 
ters the buggy, the buckboard, and the mower. Upon its walls are old-time portraits of Jackson and Polk, and the bills of races trotted just after the Civil War, and pictures of setters. An old pronged reaping cradle hangs on a peg (the large beams were all put together with wooden pins, and great seams of bark still cling to the posts), and hoes and scythes and other implements are similarly suspended. The rifles are occasionally leaned in a corner after a hunt. An old pair of dusty saddlebags, for many years unused, are astride a long peg. In the loft will be found the spinning-wheel of former generations.

Here come the buckets for the hogs, and we shall follow them! The hogs are a little restricted in their wanderings now, being confined to a half-acre lot, comprising the apricot and plum orchards, whose enemies they delight to honor with their snouts. Little brass rings have been inserted into their noses, however, to prevent their rooting propensities from getting beyond their control. They are great fellows. I like to lean over as I feed them, and scratch their backs, and they reciprocate my affection with the most appreciative grunts. I imagine, after being fattened up pretty well with corn, some of them will go as high as three hundred dressed. I have seen some hogs with veritable tusks jutting from beneath their lips, and raising them slightly. They looked then like the dinosaurs and pterodactyls of eld, through whose remarkable efforts we have all been descendedso they say. 
In grandfather's time the hogs were allowed to range at will in the woods, where they would roam and root and grunt around after acorns and nuts; and hogs that have the privilege of a mast diet invariably develop a superior quality of ham and bacon. I used to like to listen to the men calling them in at dusk"Poo-ee, Poo-ee, Poo-ee!" And shortly there would be heard a scuffing and snorting down in the edge of the woods, and here they would come in a scrambling, squealing rabble-shoats, sows, and the old boar all together, soon to be gormandizing knee-deep in the nectar of swill, or crunching with amazing rapidity the grains of corn. They are genuine lovers of life.

But let us look at the cows. We shall find them in their yard, or perhaps already penned up in the cow house itself. ' $T$ is there, in Whittier's lines, that

\footnotetext{
" sharply clashing horn on horn

Impatient down the stanchion rows

The cattle shake their walnut bows."
}

But I am not afraid of them. I like to scratch their heads and stroke their sleek necks, and sometimes I grapple them by the horns and wrestle with them in a sort of rough play. They seem to enjoy it.

I like to call them in at evening-"So, boss! So, boss! So! So!" I pull out the pasture bars at one end, from the holes in the posts in which they are inserted, and one by one let them drop; and they give forth, as they fall, a sort of rude musical sound, varying with their thickness and the kind of wood the rails are made of, from a dull thumping thud to the light tank of the top one, which echoes in the recesses of 


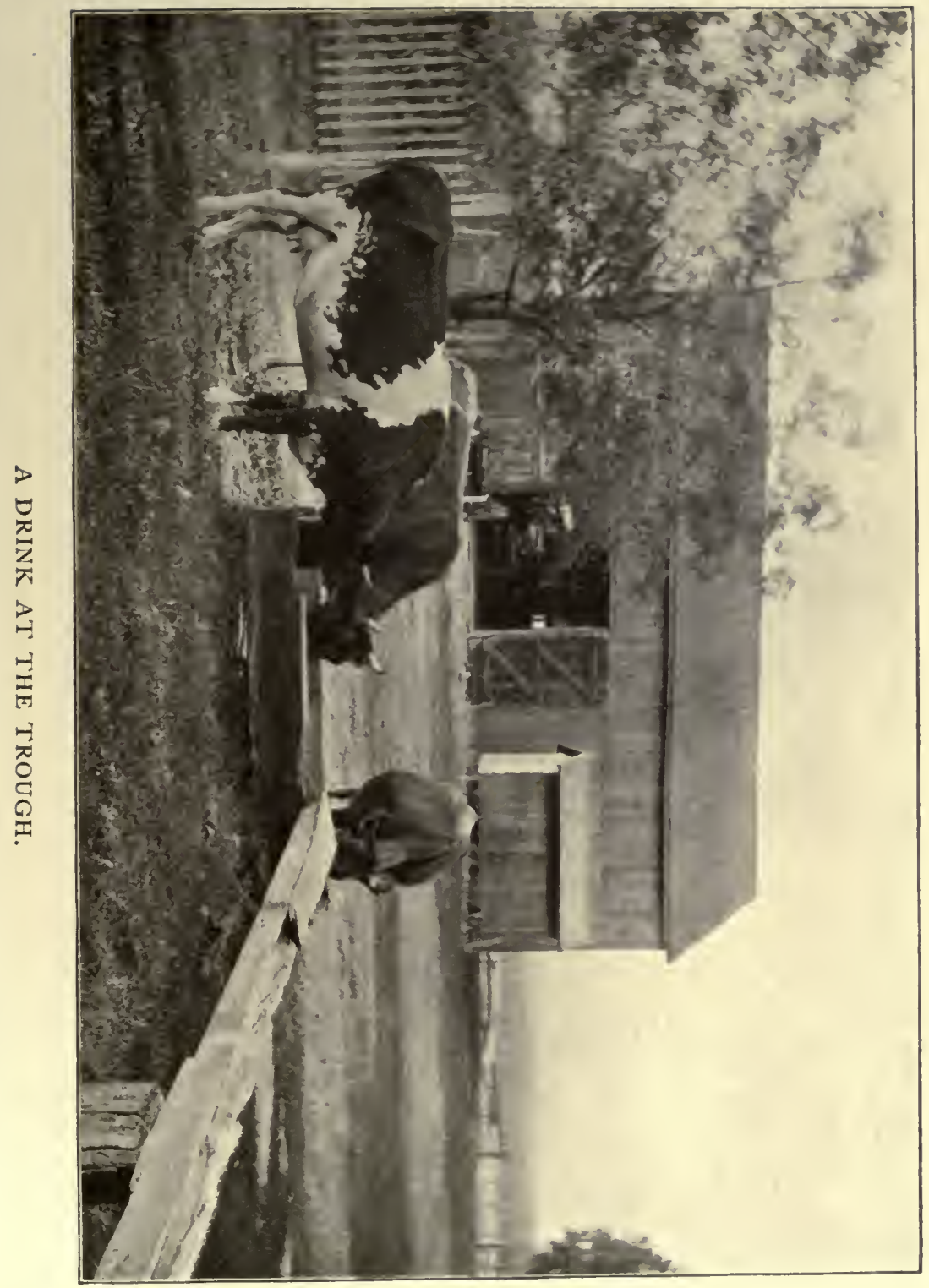



the woods. This is one of the poetic and enjoyable features of country life. Then I call again for them. And soon they come trooping along over the hills, taking a last bite of grass or nibbling off the tips of vines or the tall sweet clover. Each herd has its "boss," or leader, among them, and she invariably takes the head in their homeward journey, the others following ac-

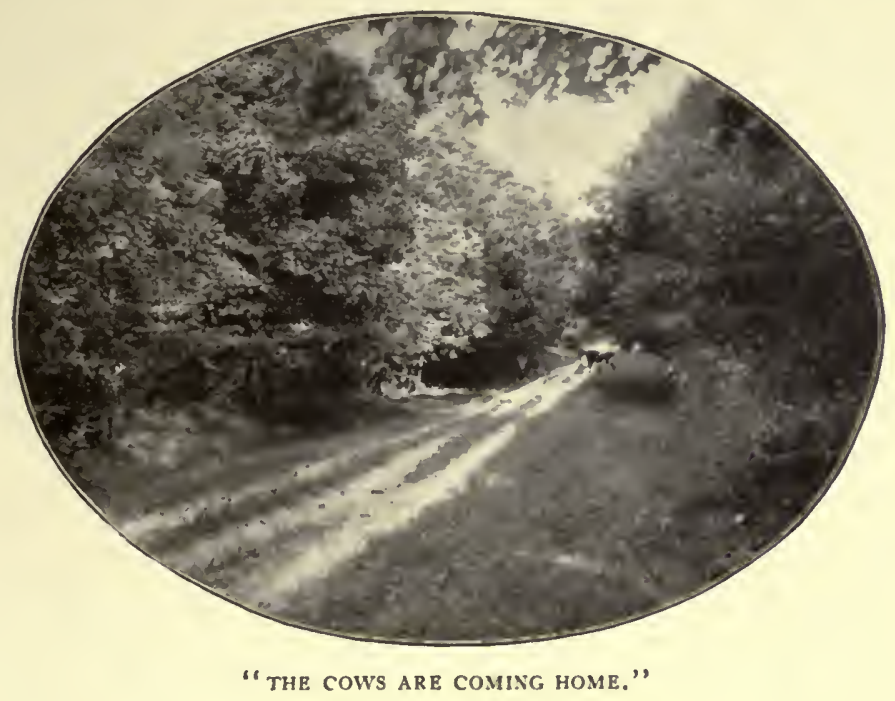

cording, I suppose, to seniority in appointment, or at least each giving way in precedence to the one next qualified to oust her. Now kine, I am told, are gregarious animals; but, when a young heifer suddenly bounds away from the herd and runs scampering and kicking up her heels through the orchard and over the strawberries, one is not so thoroughly convinced of it; and, when a calf that is patiently being fed all at once 
draws back and bucks into the milk and splatters it every which way, one is tempted to follow the example of the exasperated old deacon, who is reported to have indulged in considerable profanity upon a similar occasion. I recollect an old cow that we had, old Whitie, who would always precede the others quite a distance on the way home from pasture, solitary and unapproachable, evidently, like Newton in Wordsworth's line,

" Voyaging in strange seas of thought, alone,"

while Spottie, and Roxie, and Fawnie, and Dimple all ambled along behind in gregarious security; but then, she had been brought in from another herd, and so never affiliated very well with the others. But old Spot is my favorite-a lovely old cow. She has a good disposition toward mankind, and apparently toward the world in general, and is always content if she has but plenty of grass and clover. Yet is she "boss" of the herd, though ruling in great meekness. She has a crumpled horn, like the celebrated cow in "the house that Jack built," and she likes to have me scratch her head just back of the horns, where she can't reach it very conveniently. I always liked her. She would have made some fellow a pretty good wife, if she had n't been a cow.

I enjoy watching them graze also in the fields, as they pluck off the tufts of rich green grass with a twist of their rough tongue. Then, too, see them lift their heads among the low hanging branches of the trees, and browse on the leares and tender tips. Ah, how they love the greenery of the woods and meadows! 


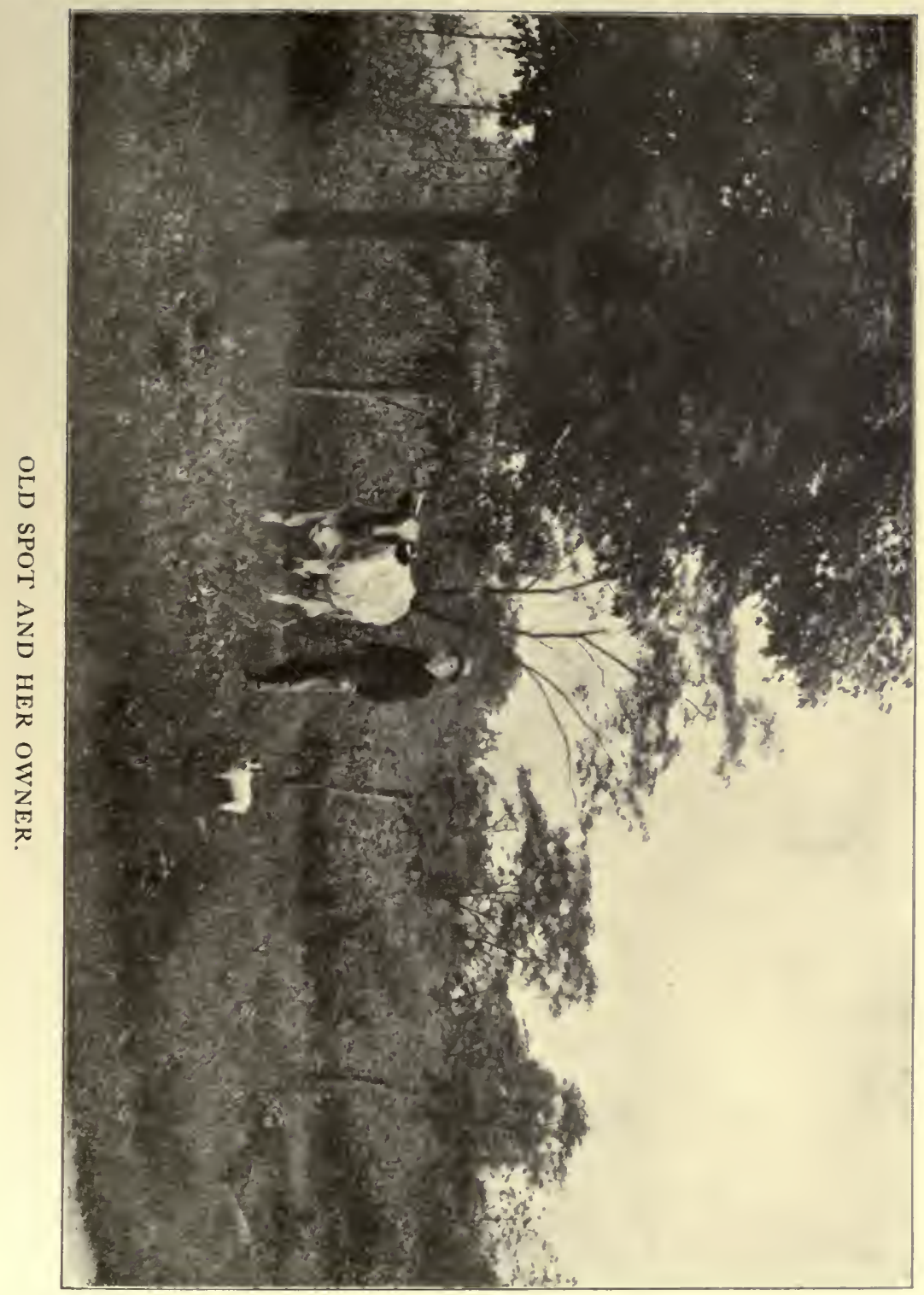



They seem especially to relish the new leaflets on the locusts and the rough foliage of the hackberry; but they will not refuse a branch of maple, or of ash, or even of wild cherry, though the boughs of the last, if separate from the tree and the leaves withered, secrete a poison which sometimes kills cattle, while there is no harm in their feeding on the fresh live twigs. They strip the vines of the Virginia creeper eagerly of their whorls of young leaves, and do not mind a taste of the poison three-leaf, or the new sprays of smilax and the wild grape. They will eat certain kinds of weeds also, and seem to like immensely to spice their grass with a bunch or two of white top. And there they stand contentedly chewing for a moment or two, with perhaps a sprig of fresh leaves left caught upon their horns. Cows, however, are very discriminating in the selection of their food. It takes something good to satisfy a cow. Sheep are not so particular, but will gladly devour almost all kinds of weeds and grasses. It is interesting to know that cows, in common with sheep and all ruminants, have no front upper teeth, but only a lower set, biting against a sort of plate of cartilage above; and that they actually have four stomachs-an apparatus far ahead of man's, but quite necessary for them, in order to take care of the chlorophyll, and so eventually to get anything worth while out of all that green stuff which they appropriate for themselves.

I like to watch the cows in winter crunching the succulent, fragrant millet, or feeding upon clover hay, or eating their corn fodder. Sometimes snow gets mingled with it from the stacks. But how they love it! How they toss it, and put their noses down into 
the wisps and stalks, and slash the great corn leaves about! The milking is generally attended to while they eat, and that, too, is always an interesting process-that is, to outsiders. Swish, swosh! swish, swosh! swish, swosh! goes the milk into the buckets, in a kind of rough purring rhythm. In summer it is not quite so pleasant, on account of the flies that bother us. Homer compares the thronging Greeks, in their eagerness to get to the Trojans, to the swarms of flies that buzz and hover about the full milk pails in the spring and summer evenings. Theocritus, though, goes even further, and says that the laborers in his time had to fasten "guards of wood, with shapely thongs, about the feet of the kine," so that they could draw near enough to milk them in safety. Nowadays, however, men are getting more merciful, and so spray their cows with a sort of fly preventive to give peace while they milk; although I have heard of an ingenious fellow who had an apparatus which tied the cow's tail to the ceiling during his period of torture, and I have seen another take a long loop of rope and chain (using the fastener in the stanchion for the purpose) and fling it over the cow's hind-quarters at milking time, this proving an effectual barrier to the switch of her tail. But watch them chew their cud in the cow-yard afterwards. Don n't you wish you could look so contented?

There is much difference in the yield of each individual cow, and a still greater difference in the quality and quantity of milk from the different breeds. The Jerseys are by far the best cows for butter; indeed, their rich yellow milk would seem to be almost all butter fat. But for a "general purpose" cow, to furnish butter, 
cream for the table, and milk for the hogs, give me a cow that is at least part Holstein. They are big eaters, because they are big-bodied; but they are big milkers, too, and old Spot, when she is fresh, will give a couple of pails brimful twice a day. Of course, sometimes the Holstein's milk does not come up to the test; it has been said that the Lord has already watered the milk of the Holstein for the dairyman. Yet are they very beautiful animals, with their white, clean background, flecked with delicate strands or flakes of black, or irregularly striped or spotted, or broadly banded.

I have seen it stated that cows do not care for their young after a certain period, and finally so forget them as not to recognize them any longer when they become older members of the herd. This is a point whereon my experience has shown differently. Our old Spot, for example, had a calf that was raised and brought into the herd, in due time having a calf of her own; and lo! this grand-calf, as we may call it, was old Spot's special guardianship; for she hooked the other calves away, but played with this one, while its mother stood admiring by.

Old Spot is part Holstein, and so, in her streaked, spotted appearance, she sometimes reminds me of what Thoreau said, in a beautiful random passage in his journal, of a heifer that he fed with an apple $:^{1}$

"One more confiding heifer, the fairest of the herd, did by degrees approach as if to take some morsel from our hands, while our hearts leaped to our mouths with expectation and

${ }^{1}$ See "Thoreau: the Poet-Naturalist," by William Ellery Channing; pp. 65,66 . 
delight. She by degrees drew near with her fair limbs (progressive), making pretense of browsing; nearer and nearer, till there was wafted to us the bovine fragrance,-cream of all the dairies that ever were or ever will be: and then she raised her gentle muzzle towards us, and snuffed an honest recognition within hand's reach. I saw it was possible for his herd to inspire with love the herdsman. She was as delicately featured as a hind. Her hide was mingled white and fawn color, and on her muzzle's tip there was a white spot not bigger than a daisy; and on her side turned toward me, the map of Asia plain to see.

"Farewell, dear heifer! Though thou forgettest me, my prayer to heaven shall he that thou mayest not forget thyself. There was a whole bucolic in her snuff. I saw her name was Sumac. And by the kindred spots I knew her mother, more sedate and matronly with full-grown bag, and on her sides was Asia great and small, the plains of Tartary, even to the pole; while on her daughter's was Asia Minor. She was not disposed to wanton with the herdsman. And as I walked she followed me, and took an apple from my hand, and seemed to care more for the hand than the apple. So innocent a face as I have rarely seen on any creature, and I have looked in the face of many heifers. And as she took the apple from my hand I caught the apple of her eye. She smelled as sweet as the clethra blossom. There was no sinister expression. And for horns, though she had them, they were so well disposed in the right place, but neither up nor down, I do not now remember she had any. No horn was held towards me."

Mr. John Burroughs, too, has written an attractive paper upon the cow, which he has called "Our Rural Dirinity," and which is quite bucolic and certainly very enjoyable.

Besides Trowbridge's well-known "Farm-Yard 
Song," there are not many poems upon cows; but there is one, entitled "When the cows come home," by Mrs. Agnes E. Mitchell, which is so full of sweet breaths from the pasture that I shall leave a few stanzas of it with you, as presenting, in a better form than I ever shall be able to do-the real, abiding poetry of our friends the cows, and their life among the grasses:

“ With a klingle, klangle, klingle,

'Way down the dusty dingle,

The cows are coming home;

Now sweet and clear, and faint and low,

The airy tinklings come and go,

Like chimings from some far-off tower,

Or patterings from an April shower

That makes the daises grow.

Ko-kling, ko-klang, koklinglelingle,

'W ay down the darkening dingle

The cows come slowly home.

And old-time friends, and twilight plays,

And starry nights and sunny days

Come trooping up the misty ways

When the cows come home.

"With a tinkle, tankle, tinkle,

Through fern and periwinkle,

The cows are coming home;

A-loitering in the checkered stream,

Where the sun-rays glance and gleam,

Starine, Peachbloom, and Phœbe Phyllis

Stand knee-deep in the creamy lilies,

In a drowsy dream.

To-link, to-link, tolinklinkle,

O'er banks with buttercups a-twinkle

The cows come slowly home;

And up through memory's deep ravine

Come the brook's old song and its old-time sheen,

And the crescent of the silver queen,

When the cows ccme home. 
"With a klingle, klangle, klingle,

With a loo-oo, and moo-oo, and jingle,

The cows are coming home;

And over there on Merlin Hill,

Hear the plaintive cry of the whip-poor-will;

The dew-drops lie on the tangled vines,

And over the poplars Venus shines,

And over the silent mill.

Ko-ling, ko-lang, kolinglelingle,

With a ting-a-ling and jingle,

The cows come slowly home.

Let down the bars; let in the train

Of long-gone songs, and flowers, and rain ;

For dear old times come back again

When the cows come home."

It is indeed a pleasure to be with animals, and to observe their ways. Animals are franker and more direct than men are in expressing themselves. You can tell what an animal means, but you can't tell much about men. I have met with few horses or dogs that would make good politicians.

What a difference between the eyes of animals and those of human beings! How open, how transparent the nature of a horse is, or of a dog or a cow, as seen in their beautiful eyes! The eyes of a man or a woman are not always so. I can not see into their souls and know their real character as I can when I look into the eyes of my little dog. Homer's farorite epithet, indeed, the best compliment that the old Greeks of the "Iliad" could think of for their lady lores, was "boopis," or ox-eyed.

Some animals are naturally neat, while others are, like some men, naturally filthy. Some, that is, one might well say, are positively brutal, while others are not. Squirrels are the cleanest, perhaps, of all the ani- 
mals, and the nicest in their habits. Some cows seem to delight in being clean, in picking out nice places to lie down in, and so keep their udders and sides free from dirt; while others, in the same herd, will invariably be about as unclean and reeking as wallowing could make them. It is the same with horses, some requiring two or three times more currying than others. Even pigs have their preferences and selective natures, and I think I could actually make friends of some hogs. Indeed, I have taught one occasionally to stand on his hind feet, and take an apple from my hand.

Animals are the best woodsmen in the world. Emerson, I believe, said that cows were the best surveyors for a railroad (indeed, the streets of Boston are said to succeed the cow paths), and I have noticed in following the paths of deer in the woods that their trails were about the shortest road to water or to the lake shore, and always went by the easiest descent. I could not but observe also how the deer would follow up a blazed line. Quite frequently their tracks led for some distance straight along from blazed tree to blazed tree. Whether they thought that other deer had perhaps bitten the bark, and so followed the blazes as deer "sign," and thus, by keeping along them in this way, found the walking gradually better and the ground harder along the old lines, or whether they had at first stepped from tree to tree merely from curiosity, to learn perchance what had slashed the tree and broken the twigs, I do not know; but their well-beaten paths have followed many a section line in my woods-work, and have diverged only to lead to water or to better forage. Deer know the glades and dingles that are 
most free from mosquitoes, and you will find their yards and haunts good camping places for that reason. A sheep path, too, is the best route for a railroad. Sheep are the surest of weather prophets, and know the difference between a real and an apparent storm. If the sheep stay out during a storm and cast their weather eye upwards with disdain and go on browsing, you may know there will be no bad weather, that it will be only a passing local shower. But if they come in toward the barn and cower behind the stacks, then you had better come in with them.

Grandfather used to have sheep, and a great time they had of it in shearing time, when they drove the flock down to the river, four miles away, and washed the fleece. There are few more delightful occupations than the raising of sheep. Even their care, and the actual handling and feeding, are poetic. They are the most beautiful, to my notion, of all God's domestic animals. There are few spots in my memory so green as the hours I have spent in the tending of sheep and lambs.

Animals, too, depend upon the sense of smell to help them much more than does man. They can tell their own young by this sense, and where they themselves have lain last, and whether they are in their own or an alien flock or herd.

The gregarious instinct in animals begets colonies of ants, schools of fishes, swarms of bees, broods and flocks of chickens, coveys of quail, flocks and bands of sheep, herds of cattle, droves of hogs, litters of puppies, packs of hounds, bevies of girls, crowds of boys, and communities of men and women. 
I sometimes wonder whether the animals ever conceive of themselves as being like others of their species whom they recognize so easily. Does a horse, for example, realize that he is like the nag in the lot that whinnered at him as he passed, or is it true of him, as of men, that, as he drinks, he looketh into the mirror of the pool and straightway forgetteth what manner of horse he was? Can it be that chickens have an individuality, so that one should say unto the other, "How can I be without thee, Scragly?" and the other should say unto the one, "How can I be without thee, Topknot?" I have seen roosters and hens so attached as to have seemingly an affection for one another. It is well known that chicks of the same hatching will roost side by side and stay together long after they have been weaned; and I have noticed two young ones, of different broods, taking walks together, and forming an acquaintanceship which, let us hope, lasted through life, for they kept together day by day and evidently enjoyed one another's companionship.

Chickens, for some reason, besides foraging on everything else they can lay their bills on, are exceedingly fond of the berries of the poison ivy, and I have seen them clamber all over a vine in order to get the last berry. Animals, too, will devour the new fresh leaves of its tips with apparent relish. They are differently constituted from us, you know.

There is no tenderer passage in the Bible than that in which Jesus compares His own willingness to forgive Jerusalem with the anxiety of the common barnyard fowl for her younglings, in these words: 
"O Jerusalem, Jerusalem, thou that killest the prophets, and stonest them that are sent unto thee, how often would I have gathered thy children together, even as a hen gathereth her chickens under her wings, and ye would not!"

Curiously, that is the one instance in the Bible where the hen is mentioned. Job propounded the question whether there was any taste in the white of an egg, and other birds are spoken of in the Scriptures; but it remained for the Master to remember the common hen. Aye, but even more than by that, has $\mathrm{He}$ sanctified the barn unto us: He was first laid in a manger, while round about $\mathrm{Him}$ on the hillsides shepherds watched their flocks by night.

I like to watch the chickens as they drink. How they lift their little heads, and let the cool drops trickle down their throats, in evident pleasure at it! Truly they, too, are lovers of life.

Do animals think and ponder? I see no reason why they should not. The force of habit certainly becomes very strong upon them. I know that calvary horses get so used to the bugle that they obey the calls as readily as the men. And I believe that an old farm horse knows whether he is going to town, or to the field, or just down to the post-office, by the different sets of harness we put on him. Perhaps he will look forward to the long ride and wonder how heavy the load will be. A horse used to a certain route certainly knows where to stop, and a loose horse, even out on a prairie, can generally find his way home if he wants to. $A$ horse familiar with the road is frequently a safer 
guide than a man not well acquainted with it. I have had a horse take me safely to where I wanted to go when I myself was somewhat bewildered; I simply let him have the lines to himself, and guided him only when he turned of his own accord. I believe they think. They are perhaps not so different from human beings. But they can not tell us.

Now no man can serve two masters, nor can a horse, or a dog, or any other animal; for either he will love the one and hate the other, or else he will hate the one and love the other. So much for the training of them.

But let us go back to the barn. The barn itself is the special repository of the horses; and ' $t$ is here the thralls clean the Augean stables. The wagons are in it, too, and the plows and harrows; and all the harness is hung on pegs behind the stalls.

Horses are really exceedingly intelligent. They know as well as a man that rain water slakes the thirst better than any other. Like cows, they will frequently prefer pools of rain to even freshly drawn buckets from the well; and in spring, when it is still cold enough to freeze in the nights, I have seen them break the ice in the pasture lowlands with their forefeet in order to get at the water beneath, although they had just been offered a trough full at the barn. We once had an old mare, who, though she could n't speak, was a smart old lady, and used to cross one foreleg over the other to brush the flies away, thus killing two birds with one stone, as we say. Most horses have much more intelligence than men and women commonly think they have. As they grow older their eyes assume a 
wise and knowing look, much different from the eager stare of a colt unused to new impressions.

It is a great experience to have made friends with an animal. They know all our individual ways as much as we know each other. They know who will give them an apple, or who a beat on the head. Horses have their moments of peace and joy and sorrow; they have their pensive and playful moods; and they have their fits of anger and waywardness, like men and women. It takes a good deal of sense to understand animals, and to be able to care intelligently for their wants; and there are more of these, and much more sense is required, than city people generally think. A man can learn much from the animals. A well-bred dog is very much of a gentleman, and a faithful and good-natured old horse is an inspiration to better service in the world.

Bill is about the most common name for a horse. There is always a Bill in every barnyard, or a Frank, or a Jim. I know of one old farm where the name Billy had been such a favorite as to have variously been applied to as many as three of the horses by their owners. Dollie, among the gentler sex, is perhaps the name most generally given, or Flossie, or Jennie, or Queen.

It is surprising, the real courtesy shown by the males toward the females by our horse friends. This is no mere fancy. I have seen it in more than one in. stance, but I recollect one old horse in particular, with whom I had to do at that time, old George, who would always persistently refuse to come out of the pasture, when we opened the gate, ahead of Lizzie, his mate 
on the team. No matter how far behind she was, or how much we urged him, no, sir! he would not go through the gate until she came. 'T was against all precedent and decency! But when the mare finally sauntered up, old George would lift his head proudly for her to pass first, in genuine heroic deference and with a touch of true chivalry. I always liked the old fellow for that, and sometimes he got a handful more of oats than I was told to give him.

Horses always know one another, and frequently two or three will become great cronies, will drive well together, and will enjoy one another's presence. The mere appearance of strangers will cause heels to project forcibly behind and other symptoms of displeasure to become noticeable. But I have in mind two old comrades, Billy and Dandy, who had been driven together for years, and had got so that they understood each other's ways and whims, and liked them-yes, they seemed to be very fond of each other. Billy was lazy and Dandy did the work, and perhaps that was the reason why Billy liked Dandy; yet Billy was really of an affectionate nature, and we all liked him, notwithstanding his "cussedness," and perhaps that was why Dandy liked him too. One spring they were separated in the teams, and were driven with other horses. Some weeks after the separation I was standing with my team getting ready for the field, when Billy spied Dandy, and came up to him, and evinced all possible signs of appreciation toward him, and rubbed noses with him-kissing him, perhaps, as we should sayand then stood in the ranks beside him, ready and eager to be hitched up with him as they used to be; 
and then, when I drove away leaving him alone, he looked so forlorn and disappointed that I was sorry I had n't him with me. But another teamster came, and he was led away with some others. Dear old Billy and Dandy! I wonder where they are now, and whether they are yet alive, and who feeds and beds them. It will not be long before they will die, and be taken out to the fields they had loved and been in so much. I should like to be there to soothe their last moments with whatever of alleviation my human aid could give. Surely, if a good horse does not go to horse-Heaven-well, if he does not go there, then I say that he should go there, and that it 's a shame that he does not! But our better natures tell us that he does.

Animals have many ways of expressing their feelings and of communicating with one another that we do not always observe. Different modulations of the roice-of the baa of a sheep, or the moo of a cow, or the whinner of a horse, or the bark of a dog, or even the grunt of a pig-express different shades of temper, such as fear, anxiety, comfort. My dog can tell me more by a sudden movement of his ears than if he had spoken. Animals are more observant than men. A horse will notice a wagon across a field long before a man will. And so are animals better weather prophets than men. They know the lee side of a haystack; and the caw of the crow and sudden hurrying of the sheep mean the storm is at hand.

We say that man is the highest of animals, and has dominion over the rest of creation; and we are right. Yet let us put ourselves in the others' places. Man builds suspension bridges, houses, barns, fences. Now 
horses do n't do these things, and the presumption is therefore that they can not. But if we had only four big hoofs, and could eat nothing but hay and oats, and whinner, could we act much differently from our horses, no matter how magnificent a brain we might have concealed beneath our great long ears and coat of hair? Is it not man's superior equipment which gives him his power, and which has developed his brain? If we should become horses and dogs, would we, I wonder, be as intelligent as they?

If we could only know, doubtless we should find in these great dumb beasts-dumb, so far as our speech is concerned-with their soft lips and great coats of hair and waving manes and sensitive nostrils-I say doubtless, if we could only know, we should find a rich soul life there; associated, as their life is, with all the influences of Nature, the water, the dewy grass, the fresh earth, the sky-all those facts that we account most beautiful and sacred and uplifting in our own lives. And why not in theirs?

Books do n't teach a man everything. There is a great deal that can, and ought to be, learned outside of books in the school of life, among men and animals, and with the flowers and grass under the blue sky. I can not give any other interpretation to certain things I have noticed among my dumb animal friends and companions through this world than that the animals, however vaguely or dimly, share with us the same feelings and sensations and, so far as I know, the same thoughts, that the varied experiences of life give rise to and intensify in our own minds. They certainly have a sense of mystery, and, rudimentary though their 
mental apprehension may be, as compared with our own supposedly superior make-up, I fondly believe that they find life as we find it, and perhaps have, in their own way, the same perplexities and the same solace.

I think we should treat our beasts well. As I have had the care of horses in various places, I have noticed how evident was their appreciation of any little kindness done to them, as the gift of an apple; and I have never found that I could manage them any the less easily for it. The command to observe the Sabbath is just as binding upon the horse as upon his master. None of the ten is more openly broken than that. I have been glad to observe many exceptions to it, but it is not all of our beasts of burden that have their Sabbaths. Yet the command went out: "Remember the Sabbath-day, to keep it holy . . . in it thou shalt not do any work, thou, nor thy son, nor thy daughter, thy man-servant, nor thy maid-servant, nor thy cattle, nor thy stranger that is within thy gates." A love for animals, a sense of our kinship with all the animate world, is one of the most refining influences of life. "The merciful man is merciful to his beast."

When one looks upon the proud form and bearing, the beautiful eyes, the erect carriage, and the superb mane and tail of a horse, one is moved to the greatest admiration. It is no wonder that the author of the Book of Job loved the horse. I like to see them roll and kick up their heels, and then start to graze at once on the grass and clover. A horse that can roll over and back again is, according to the old saying, worth a clean hundred any day.

This noblest beast of burden, the horse, has re- 
cently been written of by Mr. Jenkin Lloyd Jones, in his "Jess," with such tenderness and affection that no one with any heart, and especially no one who has had the care of animals, can fail, by the reading of it, to be made more humane to these beautiful forms of life, so winsome, so loyal when their service is appreciated, so appreciative themselves, everywhere about us. Burns's poem, "The Auld Farmer's New-Year Morning Salutation to his Auld Mare Maggie," expresses this same affection of a man for his horse and of the horse for his master. I think, too, of "Black Beauty."

I have a sermon that I have much enjoyed, "Christ among the Cattle," by Frederic R. Marvin, which I wish could find a very wide circulation, teaching, as it does, our responsibility for these dependent fellowbeings, and the pleasure that we should have in sharing their lives.

A man is rewarded in more ways than one for good care of his horses, but it is enough to see them happy and enjoying themselves. There is a poem by $\mathrm{Mr}$. Hamlin Garland, in his "Prairie Songs," entitled "Horses Chawin' Hay," these few stanzas of which give the best expression that I know of to that feeling of genuine satisfaction which a man has in a barn, while hearing his horses crunch out their appreciation of his generosity:

"I tell yeh whut! The chankin'

Which the tired horses makes

When you 've slipped the harness off' $m$

An' shoved the hay in flakes

From the hay-mow overhead,

Is jest about the equal of any pi-any;

'They's nothin' soun's s' cumftabul

As horses chawin' hay. 


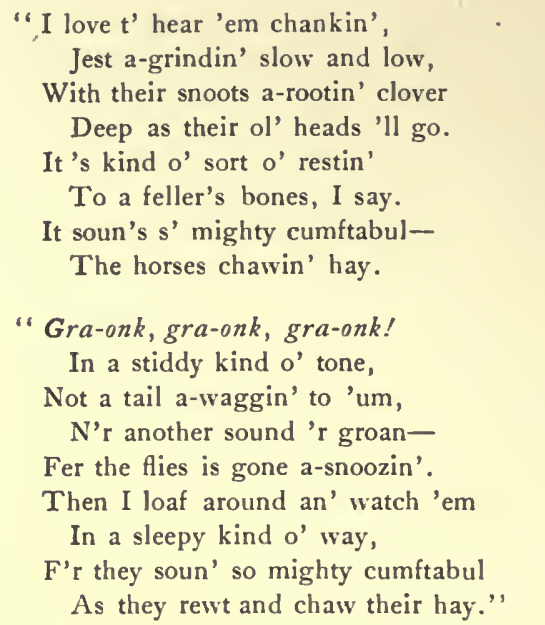

And so the barn has brought out among our friends and humble servants, the animals. There is a pleasing sketch upon "An Old Barn," by Dr. C. C. Abbott, in which he tells us of all the birds and other forms of wild life still lingering beneath its abandoned, loosened roof. Wilson Flagg also wrote upon barns, and Thoreau said he was glad Flagg had chosen for one of his themes such a subject, for it smacked a little of wild Nature, and recognized Nature "squarely."

Let us throw down some hay, then, and some straw; and let us milk the cows, and slop the pigs, and curry the horses; and then let us feed and bed them for the night. 



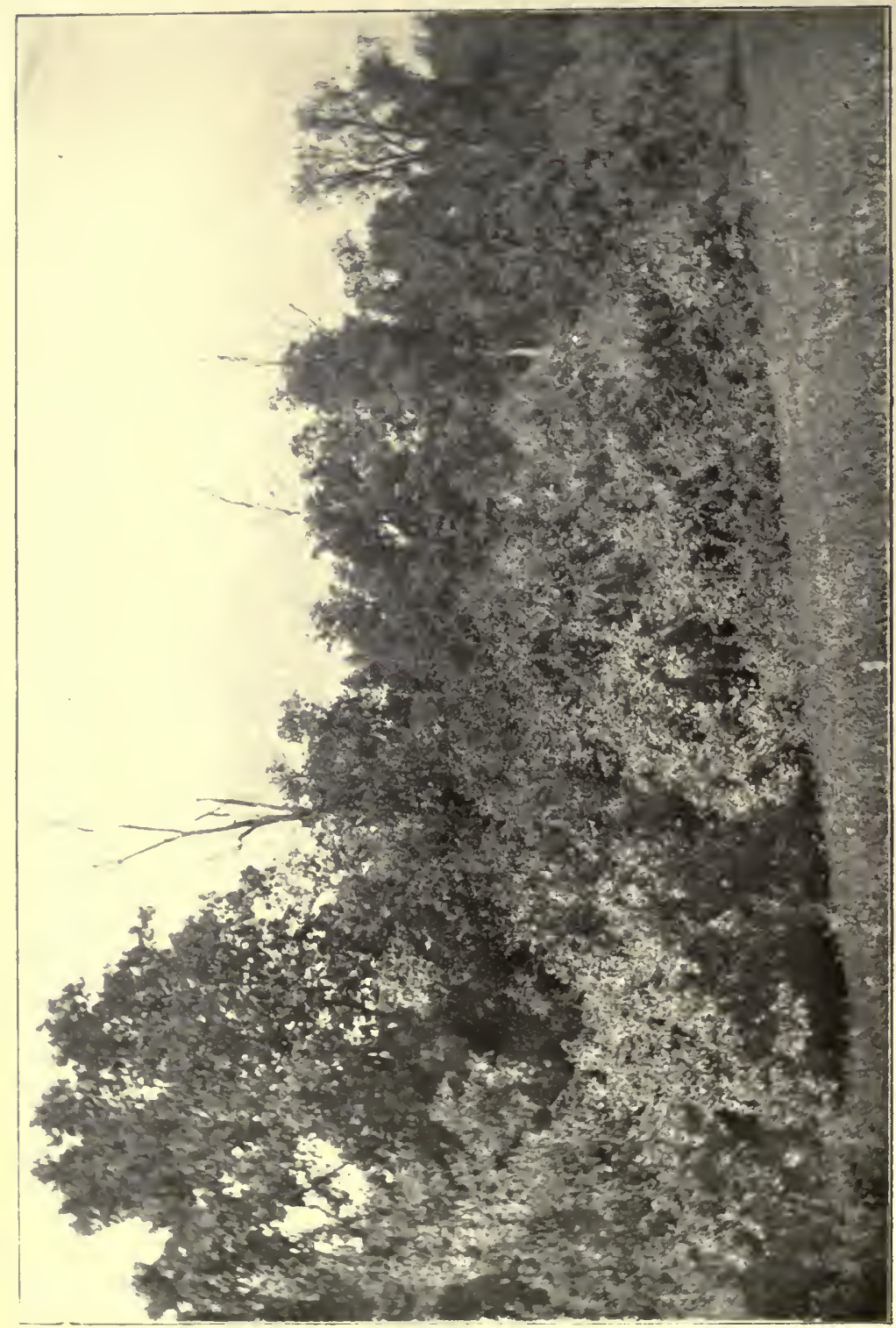

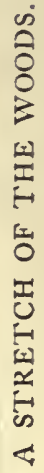




\section{THE WOODS.}

"This is the forest primeval."

-Longfellow.

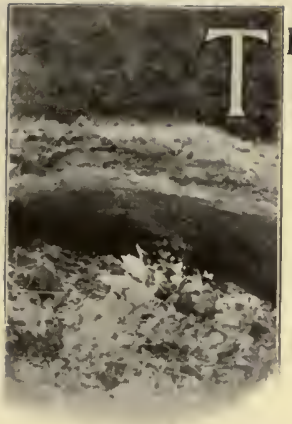

HE greater part of the woods stood, originally, back of the barn. There the trees had reared their massive stems for centuries upon the knolls and along the brooks; useful to the pioneer, in his day, and much more valuable, those that have come down still standing, to later generations. Stumps can occasionally yet be seen where the old trees were; and what little of the vast tract is now remaining is A MOSSY LOG. one of the last bits left of the magnificent primeval forest of virgin timber which once covered all these hills.

The barn was new then, and its great beams and rafters were hewn by the broadax in the very woods which sheltered it, and from trees cut, in those early times, freely, to make clearings - the straightest and finest trunks being selected for the buildings, and the others rolled and piled together, logs and branches, and burned, to open up the forest for the fields of wheat. So it happens that the houses and barns erected then have in them the most durable of lumber-oak, black walnut, hard maple, hickory-as commonly as now we find the pine, and outlasting, for that reason, the more recent edifices. 
The old place-a half section-primarily extended for more than a mile along the turnpike. The woods then was of immense extent, and was overrun with squirrels and 'coons; and many a tale of prowess has been related of shooting 'coons by starlight only, or eren in absolute darkness, so keen was the eyesight of our forefathers. Even I can recollect when the old woods was so big that from any point near its center I could not see cleared land anywhere ahead through the trees. It was an easy matter to get lost in it. It seemed then, in my boyhood days, to be an absolutely endless forest, a gigantic stretch of waving, majestic monarchs, nothing but trunks and tree-tops everywhere I gazed, filled with all the enchantment of the snare and still hunt, and hallowed with illimitable beauty and mystery. And it has not lost all of its beauty by the removal of the trees; for, although there is more light under them, some of the trees are there yet, and the old woods still looks quite familiar and much as it used to appear.

There was a certain portion of it, near the highway, where the growth was more open, and where, consequently, gypsy caravans used regularly to encamp. I well recollect how my boyish fancy thrilled at the first sight of them, as their dusky figures moved to and fro beside the crane and the kettles in the weird, dancing firelight, while gypsy dogs barked warningly at us newcomers. Surely here was the long-lost happiness. I thought; or, at least, a little of pure romantic wildness, inclosed among the dim trees, under the stars.

Let us ramble, then, together for a while beneath the leaves on this fair afternoon, and see if perchance 


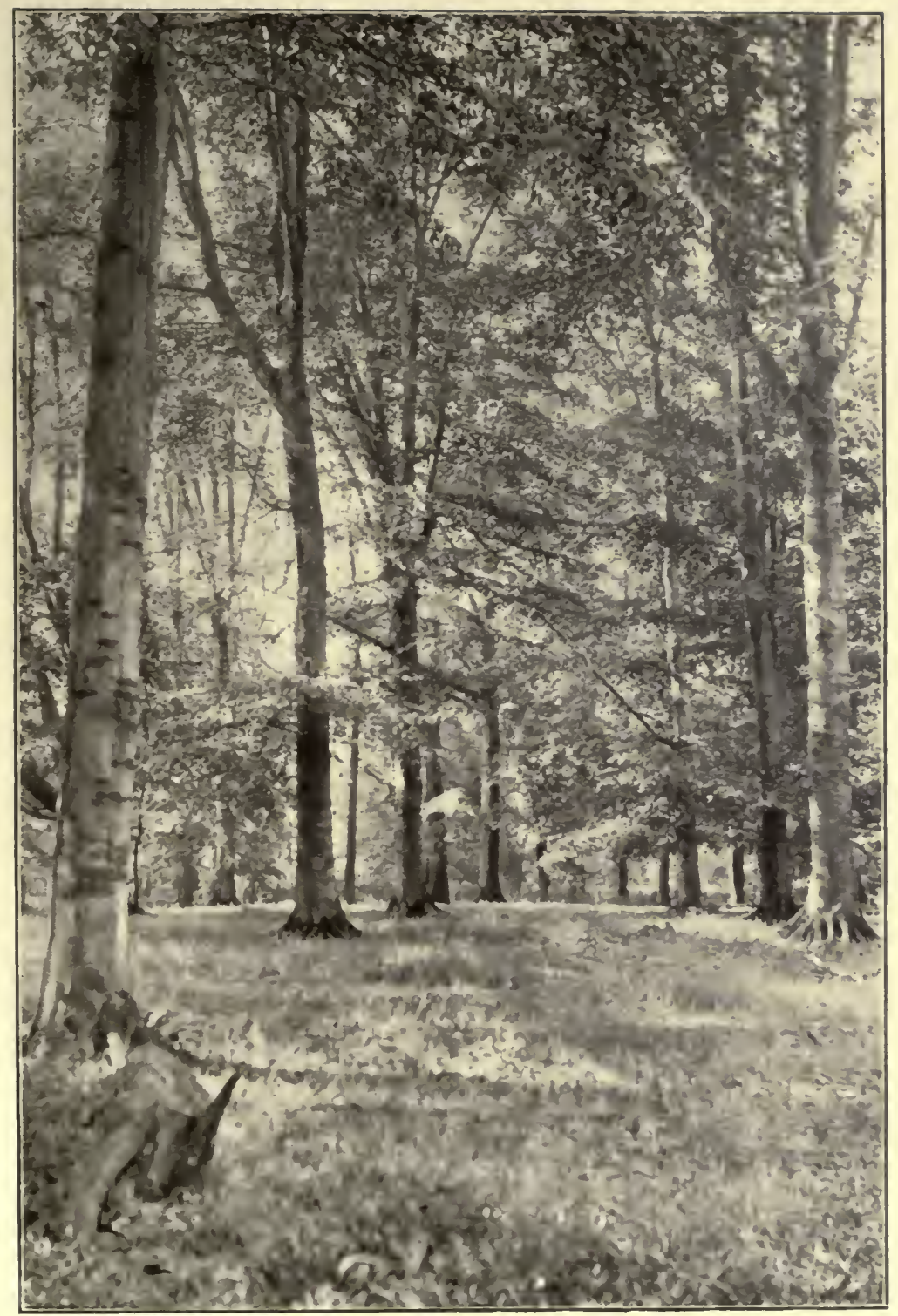

"THE VAST CATHEDRAL OF GOD'S TREES." 

we shall not find a friendship with the old monarchs, or a hint of by-gone days and the life of the frontier.

Entering beneath the low-hanging, drooping branches of a beech, we find ourselves at once in the vast cathedral of God's trees-long reaches of leafy solitude, airy vistas, beautiful depths of shade, all odorous with the scent of blossoms, of decaying forest litter, and of the many other perfumes of the woods. The floor is carpeted with wild flowers, ferns, grasses, and innumerable leaves, with downy couches of moldering veterans as our resting places; the ceiling is of leaf sprays, composing a living, interlacing greenery, softened in the days by dappled flecks and broad bands of mellowing sunlight falling as through stained glass windows among the shadows, and at night mingling with the pale stars and the subdued, gray light of the moon; the walls are of the rough bark of trees, manycolored, differing in hue as the trees are separately tinted, mottled with exquisite lichens, and variegated with equally delicate and beautiful vines coiling about the trunks, all combining thus into the rare old tapestries and mural paintings of the woods; the aged boles themselves being the pillars, the supports for this roofcanopy of Nature's architecture, and, springing from them, many tough, strong arches spanning the heavens, upholding in their outspread arms a fine fretwork of twigs; the aisles, the old wood roads, strewn with leaves: What a delightful place it is! We are ushered in by the praise of many wood voices and the lisping of leaves. Afar off, as in some sylvan cloister, in the dim recesses, one can hear the faintly modulated song of a bird, like a thin, attenuated shred of a human 
soul, in the forest-as it were the voice of a priest deep in the distance chanting the litany.

There is an abandoned path yonder winding its way leisurely into the woods. The old paths-whither do they lead? If we could but trace them, and knew the feet that had passed over them! How they twine in and out among long-forgotten fields of golden-rod, in under drooping boughs, or perchance through a small belt of timber, where the paths are scarcely discernible now on account of the saplings that have sprung up in or near them. Every now and then they cross little stretches of open grass, to disappear again into the thickets and the dimness. Perhaps the one now ahead of us was once used as a cow or a sheep path, or led to the spring for water from a cabin, and it may have served at times as a gypsy patteran. How many memories cluster about it! The old path remains hard, and consequently no grass grows upon it to obliterate it. Even where the underbrush comes up and obscures it, the meandering footway is still apparent, a long line running through the forest, covered with matted fallen leaves. As we follow it, though often the trail becomes uncertain close at hand and dwindles because of the myriad leaves that have drifted about and filled it, we can see that it borders an old rail fence and leads far beyond across the brookwhither?-and why?

These old zigzag, stake-and-rider, snake fences are the only ones that have any poetry to them, but they have; and as I have pulled them apart and loaded up the old lichened rails, useless now except for firewood, I have wondered who first split them long ago, and 
who made the notches, still visible even in their decay, in which the upper ones rested. It is interesting to notice the different kinds of timber used for rails in those days. Some are of walnut, actually fine black walnut that split, and used for rails; some are of elm, or of black locust, and perhaps there are a few oak rails among them; but not many other kinds of wood will last so long, for these fences were built over fifty years ago, and yet serve their purpose to mark out the limits. Generally just the best were employed, and those only that split. Hickory, ash, and poplar, however, were also used for rails-anything that split easily - and only the straightest of those.

Do you hear it-that sweet, clear whistle from the brush? There is something very romantic in the call of the quail. I remember how as a boy I used to listen to it with a thrill of delight. It seemed the very embodiment of all the wild life of the woods-Bob White! Bob White! Bob, Bob White! And it still inspires me when I hear it.

As I step quietly among the trees, the frisking and sudden barking of a squirrel there on the black walnut set me all a-tremble, and I softly approach closer to watch him. It seems, at this instant, as if all the experience of past generations has all at once come upon me-their pioneer life, their daring, adventurous exploring of the wilderness, rifle in hand, in search, too, for a hunt after the game; and perhaps, more than that, an unconquerable, ineradicable savagery antedating even their intrepid quests; an untamed, primitive, native sense of the wild! Is it that, or what is it, that now surges and surges through my blood? I can not 
resist it, and I would not if I could, for I love it. And the mournful notes of the dove amongst the branches of yonder aged hickory-they, too, throb in my spirit, and bespeak the utter loneliness and solitude of the forest.

To walk among these trees and ferns, amid the lisping of leaves, or to lie upon earth's mossy restfulness near a tinkling brook-surely, this is a part of Paradise! A place, one might think, at least for Theocritus, or, in its sterner aspects, even for Dante.

In spring, what? Opening blossoms and greening wood roads; slopes of spring beauties; birds bubbling forth their music-warbling, yodeling, caroling-pealing out what not from their little throats. What a variety in the early spring colors-the pink and light green of the buds, the myriad hues of the blossoms of the sod and the trees, the redbud and the dogwood! And the old woods boasts, besides the Claytonia, the pepper-and-salt, blue, yellow, and white violets, wood sorrel, sweet IVilliam, Jack-in-the-pulpit, sweet cicely, wild ginseng, Dutchman's breeches, squirrel corn, wakerobin, the true and false Solomon's seal, and many other wild flowers, each in its day, while ferns of graceful forms - the maidenhair, evergreen, woodsia, polypody, rattlesnake fern-come pushing up their curiously curled fronds, and along the brooks the wild ginger spreads abroad its wide leares.

In summer? The great trees canopied with their green coronals, the long, droning hum of the forest, the rich scent of mint and pennyroyal. The greenbrier and climbing sarsaparilla, wild morning-glories, the poison three-leafed iry, and the true five-pointed 


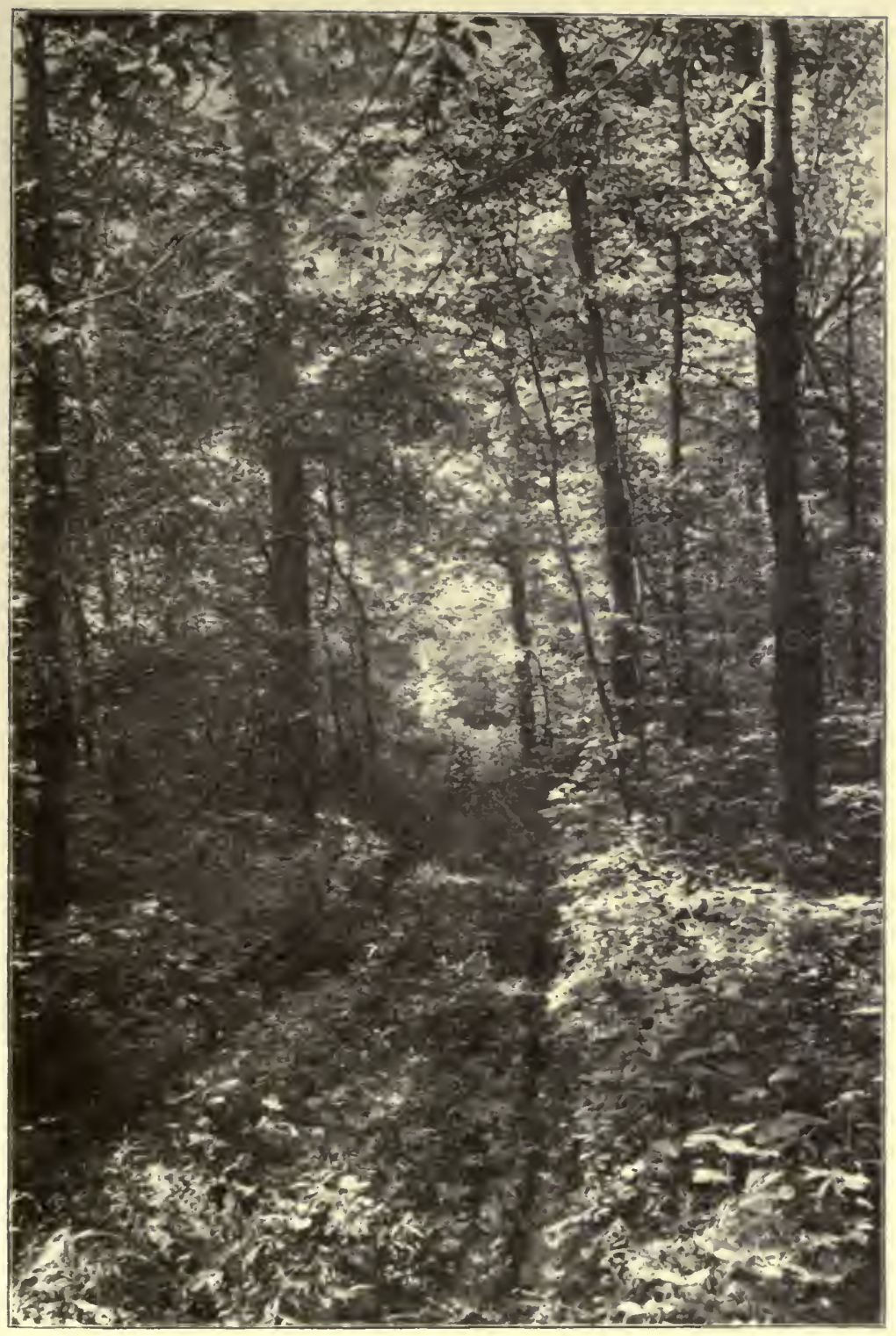

THE ROAD THROUGH THE WOODS. 

woodbine all form bowers of shade above some bending saplings, or impede our path by their intrepid growth. And the blackberries, big ebony fellows, looking sweet and delicious there beneath some vines; while mulberries hang from the trees, and the ground is dotted with them as they have fallen and silted among the leaves and grasses.

Toward the autumn? Color, and the instinct for the chase. The old wood roads and fence corners are fringed with a maze of yellow golden-rod and purple iron weed. Then, too, closing the summer, come the long racemes of wild black cherries; and, later, or along with them, the pendent clusters of wild grapes; and the papaws yellow with the year, and fall and tumble and roll to their secret hiding places among the weeds, there to await the culminating touch of a hard black frost before their final rich flavor can be appreciated. The many kinds of nuts, maturing and enlarging in their green hulls during the long hot months of summer, now, in these cool days, in the fall of the leaf, are filling the old woods with a rare, exquisite fragrance, while squirrels frisk among them in the branches and send their shucks pattering to the earth as they gnaw and munch the sweet kernels. What wonderful little pieces of architecture the acorns are-miniature mosques in themselves! They strew the ground everywhere beneath the oaks, and bits of nibbled shells, too, almost a snowstorm of them, where the squirrels have been eating. What a delight to work beneath the many-colored trees in their autumn glory! The great leafy tents and the stray branches beneath them are a wonderful harmony of color-golden, golden!-one of 
those artistic effects in Nature which men have always attempted to copy, but have only succeeded in suggesting-the yellow of the leaves casting a beautiful glow through the woods in this season of the year, a subdued, mellow light, as of the reflected splendor of a sunset-the twilight of the dying year.

In winter? Bare boughs, except now and then a branch of dead beech leaves or of oak; snow marked with tracks; evergreen trees seen at a distance among the hardwoods; and the smoke from the sugar camp toward the early year.

In all the seasons, in these dingles and nooks in the woods, one may perhaps get glimpses of a too soon forgotten Eden. How beautiful it all is, as I think of it!

I have seen at least these birds flitting among the trees or perched on their staghorn tops-the robin and chewink, wood thrush and brown thrasher, cardinal and scarlet tanager, common bluebird and indigo bluebird, yellow-breasted chat and wild canary, chippy and song sparrow, ruby-throated humming bird, Carolina wren, blue jay, cedar bird, chickadee, flicker, red-headed woodpecker, big sap sucker, little sap sucker, blackbird, chicken hawk, crow, mourning dove, meadow lark, woodcock, quail. In the day turkey buzzards soar and soar above the trees, and in the night whip-poor-wills and screech owls cry and whinner. Great flocks of wild pigeons used to roost in the woods when they, like the buffalo, had life, and had it abundantly.

And I have noticed, at different times, raccoons, opossums, skunks, weasels, gray squirrels, big fox squirrels, the little striped ground squirrel, rabbits, mice, 
and moles among its wild inhabitants, while horses, cows, sheep, and hogs have browsed and fed beneath its cooling shade. Formerly wolves used to howl at its edge, foxes crept stealthily through it, and wild cats crouched on the limbs; and no doubt deer have nipped the leaves in pioneer times, while wild turkeys fed on the nuts: Among the reptiles, black snakes, blue racers, and the harmless garter snakes glide and wriggle about or writhe and fold among the stumps; small lizards and the larger ones, more fish-like in their scaly coats, may be seen occasionally slipping about in the leaves and over the logs; and the slow, solemn, checkered turtles are to be found in the wet places of the brooks, or rarely may be met with taking a deliberate course across the woods. Snails of various sizes slowly make their slimy way about the leaves or up along the trunks, and the ground is covered in places with their shells.

The old woods is thus the home and the sustaining nourishment of many fellow mortals, of whose interesting lives we might know more could we but disarm their fears by disarming ourselves and cultivating a friendly familiarity with them.

I think, too, that few areas of its size will be found to have quite so many varieties of trees, not only in species but also in genera, as this little remaining strip of perhaps some twenty acres of woodland. Here they are according to families, in the order of their abundance:

Aceracea-Sugar (abundant) and black maple (a tree or so). Many of these are "curly" maples, it seems, as it turns out in the felling. 
Fagaca-Beech (plentiful). White, red, and yellow chestnut oak (a few left of each).

Juglandacea-Black walnut (frequent). Shagbark and pignut hickory (a dozen or so together, but with many saplings).

Leguminosa-Redbud, honey locust, black locust, coffeetree (quite a number of each).

Ulmacea-White and slippery elm (both well represented).

Oleacea-Blue and green ash (not uncommon).

Rosacer-Shad bush (one little sapling). Wild plum (two thickets). Wild red cherry (a small tree). Wild black cherry (some beauties).

Moracea-Red mulberry (two big trees, and a few small groves).

Cornacer-Flowering dogwood (quite noticeable in the spring). Sour gum (one solitary specimen).

Betulacec-Ironwood, or hornbeam (some big enough for wagon hubs). Blue, or water, beech (one tree only).

Celastracea-Waahoo, or burning bush (along the old wood roads).

Annonacea-Some scattering thickets of papaws.

Lauracea-A clump of sassafras.

Magnoliacea-Tulip-tree, or yellow poplar (two specimens).

Tiliacec-Basswood (one lone medium-sized fellow, persisting tranquilly near some giant maples).

And then, besides these, just across the road are a couple of sycamores; along a brook only a few rods away, in a field which originally was a part of the woods, but which was long since cleared off, is a willow: still farther off, in a former pasture, where also blossoms the wild rose, are some buckeyes; the common elderberry and staghorn sumac skirt the hollows and 


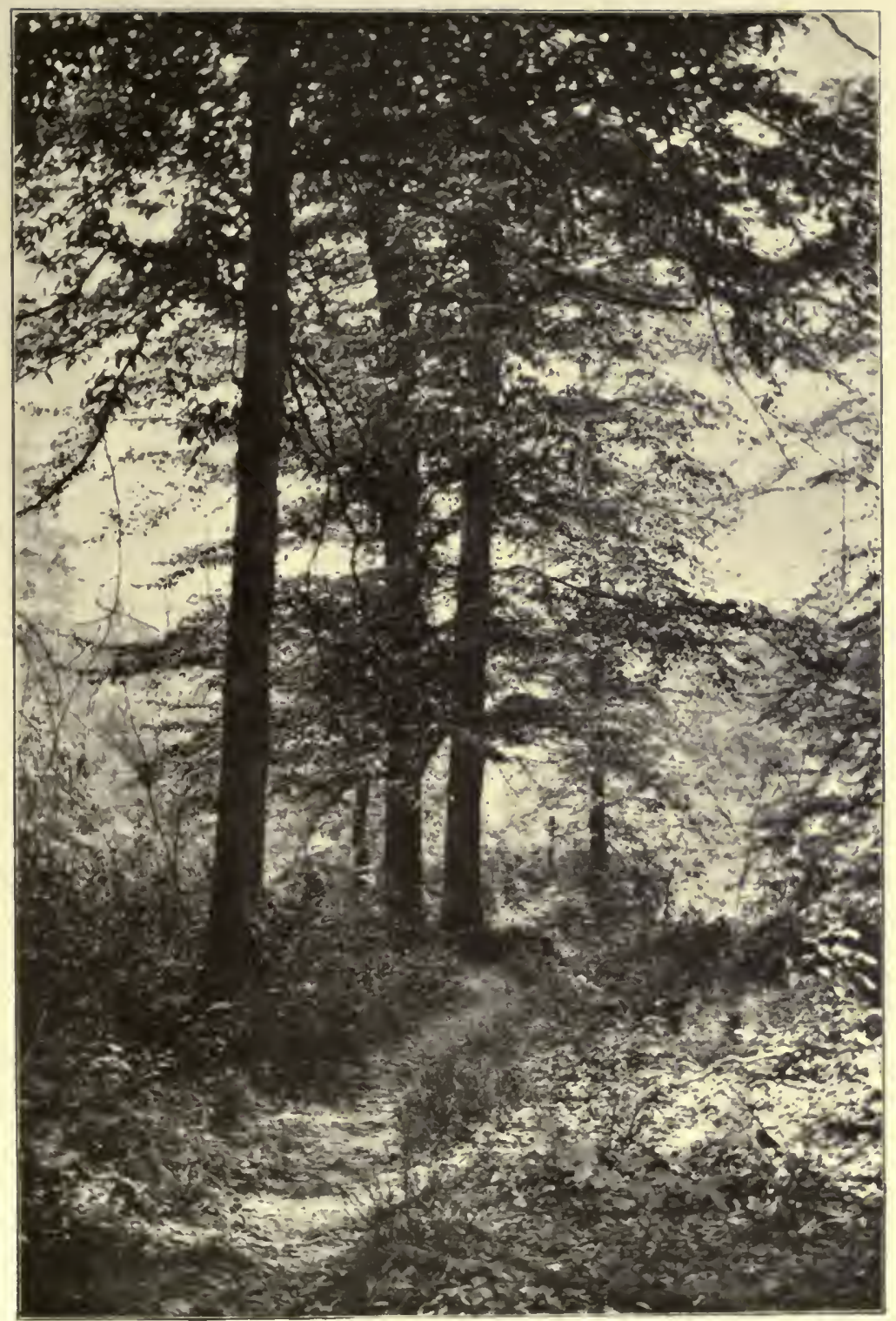



roadsides; and, to be seen at times amongst these older generations, are, finally, a few young saplings of common juniper and red cedar, sprung from seeds dropped by birds that had carried them from trees planted years ago about the homestead. Why, the old woods has in and about it nearly forty kinds of trees, with more merchantable varieties among them than are to be found in the entire Adirondack forest. Of the smaller shrubs, wild currants, gooseberries, blackberries, and red and black raspberries grow profusely in spots. Of trees not native to the region, but placed for ornamental purposes about the farm, are yet to be seen the red cedar, pitch pine, and Norway spruce, a couple of gray birches, and a young persimmon-tree, while formerly two Carolina poplars bordered the well, and a fine, broad-leaved catalpa shaded the trough.

Each tree, having seed in itself, as the Scriptures say, erects itself from infancy predestined, as it were, to a certain type, contour, shape, individuality; yet this resemblance of the species may be much altered in occasional single instances, by external circumstances, by its closeness to other trees, for example, and by the varieties of these surrounding trees, some being more favorable to its growth than others, as they screen or admit the light-so that a maple in one part of the woods may appear but little like one in another, and even totally different in outline from a brother in the open field.

Of these many varieties of trees not a few resemble each other in bark and structure, though each yet remaining different and preserving distinct its own uniqueness. As a rule, everywhere, trees of the same family 
will have bark which is at least similar (as with the birches), and is in some cases almost identical (as with the young red and silver maples, or the hard and red maples when very old, or the slippery and white elmsand it takes a schoolboy to tell a slippery elm from the others); but it is not uncommon to find species that are sap relations, and yet clothed in bark which is totally different (as, for example, the ironwood and blue beech), or which is at least noticeably so (as with the white and red oaks). On the other hand, the bark of that noble beech yonder is so much like the grayish bark of the little blue beech on the slope there that they seem the same species, even though the bark of the latter is somewhat fluted and wavy in appearance; and the leaves, too, are quite similar. Yet are they totally different, in family and genus (the one Fagus, the other Carpinus), in quality of wood fiber (the blue beech being sometimes known as ironwood), in their preferences of soil and situation, and in their seed pods (those of the latter being like hops, whence one of its common names, the hop hornbeam). And so with the white elms and this true little ironwood beside us. How alike the leaves and bark, and yet how unlike, after all; for the leaves of the elm are rough to the touch and thick in texture, and, if we cut through it, its bark is seen to be much thicker than the ironwood's, and the wood much softer. I have frequently mistaken these two kinds for one another at a distance, and especially when my eyes have been busied with a multitude of other trees, but on cutting into the wood one can soon detect the species, for the wood of the elm is ringporous in its nature, while that of the ironwood is very 
hard and is diffuse-porous, and the bark is quite thin. The sweet gum and hackberry, on the other hand, although of entirely different families, yet have a crinkled, alligator-like bark which at times is not at all unlike. Elsewhere in the forests I have noticed, too, that the bark of the balsam and young white pine is similar, and that of the red and white cedar, that of the tamarack and red spruce, and that of the shad bush and young red maple, or of the hard maple saplings and mature mountain maples.

All these can be distinguished as separate varieties. I am speaking only of their general exterior to one first observing them in the woods. The bark of the trees in these chance resemblances is a most interesting and delightful study, as are the leaves; for these singular similarities in appearance exist also frequently with the leaves of trees. I used to consider the basswood the male mulberry, so alike seemed their leaves; and the sycamore and tulip tree at a distance have foliage not at all dissimilar, which is true also of the papaw and magnolia. The trees thus superficially are sometimes very much alike; and yet each species preserves intact its own little points of identity, and retains forever inviolate its own uniqueness among the trees.

The bark of the trees is most pronounced in color and appearance in early spring, when the sap seems almost to show through it, even through the rough outside flakes. In summer the real character of the bark is somewhat obscured by the shade and the foliage. In autumn the bark "sets," as woodmen say; that is, the growth of the tree having been practically completed for the year, the bark hardens and grows close 
to the wood as the work of the sap is finished, and is then not so easy to peel. In winter the woody jacket forms almost the sole means of a ready identification of the trees, and the study of it hence becomes then a genuine necessity as well as a pleasure. It is when still wet and dripping with rain that the trees are most evidently alive; the mottled lichened trunks of some of them, as, for instance, those especially of young soft maples, looking like huge sleek snakes, with the spots and striped markings left slippery and fresh and clean, as after shedding their skins.

The distinction between the different orders of trees can not absolutely be determined in any other way than by the inflorescence. This is the only hard-and-fast line. The separation of trees into hardwoods and softwoods, including all the Conifere, and these only, under the latter term, and placing all other kinds under the former heading, is not a satisfactory classification, for many of these so-called hardwoods, such as basswood and poplar, are as soft as the conifers; it is only in lumbering that such terms should be used, and in lumbering the term softwoods comprises many that are not among the Coniferc. Nor are the words deciduous and evergreen much more decisive; for it is interesting to observe that three of the coniferous species, namely, the tamarack and cypress, and the exotic gingko, shed their leaves annually, and that the flowering and shiny magnolias, the American and English hollies, boxwood, the live oak (and the holm oak of Europe), and the laurel are all evergreens, though not conifers. The word evergreen, however descriptive, is, too, in itself almost a misnomer; for all trees, even those not 


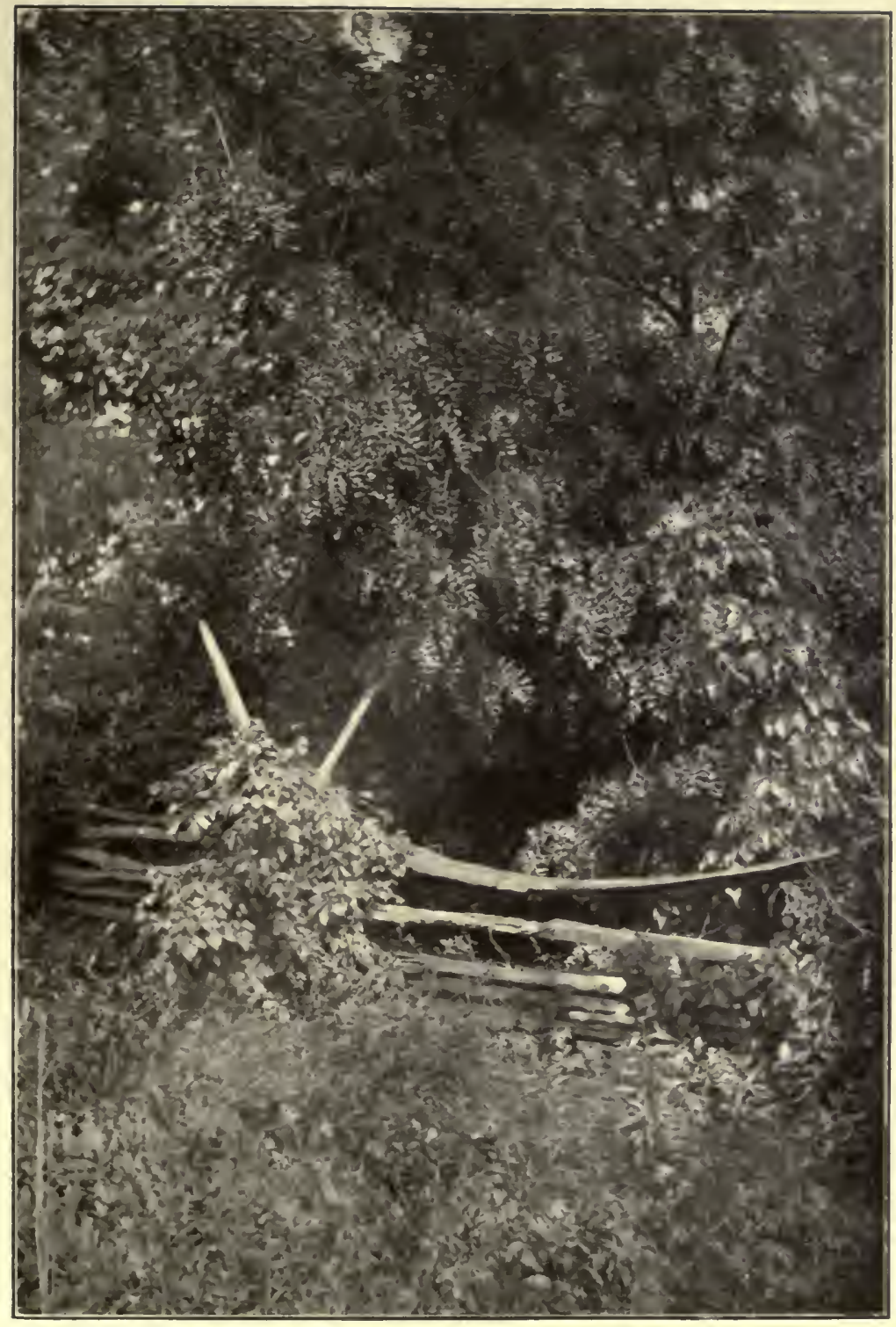

THE OLD RAIL FENCE. 

deciduous, do shed all of their leaves eventuallyrotating in a series of years, dropping some of them one year and some another, as the conifers do-even if they do not cast them annually. For all popular usage the division of trees into narrow-leaf and broadleaf species, or the sword-leaved and shield-leaved, as Ruskin called them, is the most accurate and convenient; for no tree outside of the Coniferce has narrow leaves or needles, and there is but one of the Coniferce that has broad leaves, namely, the gingko, and this is not a native variety, but an importation from Japan. It is an interesting fact, however, that some of our trees bear cones, but yet are not among the Conifera; such as the birches, alders, and the tulip-tree. Trees, too, whose flowers and fruit are similar, and which therefore belong to the same order, may have leaves of an entirely different formation; as, for example, the red maple and box elder, both of the Aceracea, or the apple and mountain ash, of the Rosacea, or the white, red, and laurel oaks. It is also possible, as has been pointed out, to find in the same genus both evergreen and deciduous species; as, for instance, the live oak is an evergreen broad-leaf among a host of deciduous brethren. The inflorescence is the only court of final resort.

The full crown of that fine hard maple yonder indicates, perhaps, that the tree is beside a spring or a water course, and is in an opening of light; which are indeed the case. The little grove of beeches there on the ridge is, as plainly as day, a reproduction from an older tree whose nuts had fallen at times and rolled some distance away on either side, yet not so far but that we can dis- 
tinguish this separate clump from the rest of the younger growth. These thrifty hickory saplings have sprung from the fruit of a majestic shagbark above us, and the two farther down the slope near the brook evidently came from a couple of nuts that bounded off down the side of the ridge. The reproduction is thicker on the south side of the ridges, where the sun reaches the seeds. If these smaller saplings could only be judiciously thinned out, what a magnificent forest there would be here in the years, trees with glorious old tops to them and without a dead limb, whose lumber would be straight-grained and clean of knots; whereas, if left to grow too crowded in this way, some will surely die, being choked by the others, and those remaining will not always be the best trees or the most desirable. These little hickories, and those ironwoods and dogwoods yonder, ought especially to be watched; for the hickories will make good maul or ax handles, the ironwoods will make first-class beetle heads, and the dogwoods will make the best of light wedges or gluts, if seasoned or burnt properly in the fire. And, besides, young trees make excellent firewood, better than that split from the sap wood of the old dead trees; for the saplings are in part heart wood, which is more solid and gives out a greater heat. That would be another advantage in thinning out the woods.

There is much difference between the growth of a tree under forestal conditions and that of one unhindered in the open. The former, unless it be a shadeendurer, like the beech, is forced because of the dense stand to shoot up at the top for its life. See, how those massive boles have struggled up into the light! The 
lower limbs of long ago have all died and fallen, because existence was denied them in the darkness beneath the thick crowns, these under branches thus decaying aside in a well-ordered system of natural pruning, so essential (this removal of the superfluous limbs) for producing the long, clear trunks suitable for lumber, and minimizing, too, the number of knots in the wood. The other, our brother of the meadow, is afforded its native expansion, develops a full crown and limbs close to the ground, and is therefore of no value except as a shade-tree or for firewood. Yet the tree in the forest-though sometimes distorted because of other trees having fallen upon it, or because its roots do not have a fair hold, growing upon the edge of a depression, and hence leaning and bending, or for similar causes-has a wildness to it, an appearance of age and of moss-clad austerity, which is likely to be lacking in its neighbor of the fields. The old trees, even in their nearness to each other, seem to stand, after all, apart, in silent, unapproachable, lofty dignity, time-worn landmarks, the grandeur of the virgin forest.

What a place, therefore, the old woods is for light on the trees' individual histories. That young elm yonder, still alive but bent to the ground, and with its tip buried in the earth, was evidently brought thus low by a larger tree in its downward fall, so fastening the sapling's top that it was never released. The dead log there testifies to that. From whatever cause the old tree fell, its descent has caused new shoots to spring up all over the deflected sapling, which finally will detach itself from its rotting tip and partially erect itself again. But its trunk, when it grows into a tree, will be crooked 
and curved to the point where one of the present shoots takes the place of the main stem, but from there upward will be as straight as a new tree, unless some similar chance should befall it later. The same thing can frequently be observed near streams. The bowlike trunks of those overhanging beeches near the brook have plainly been caused by the constant washing away of the soil from about their roots, with the consequent leaning of the tree in the direction of the water. A middle-sized maple near by is also bowed over, at a notch made by hunters. Perhaps its hollow interior had been the refuge of a rabbit or squirrel in a hasty retreat, and the game had then been cut out from above, and the tree had at that point been weakened. A larger ash, farther along, with the base of its trunk crushed and distorted, apparently shows the effect of a heavy weight of snow, or of a dead limb, which perhaps had fallen from a larger tree, and accidentally lodged upon its tender stem, in its early seedling life.

And what an interesting bit of curious history the face of the cross-section of a tree is, as we look at the old stumps and the ends of the fresh logs, just cut and lying in the woods:- the first early growth; the remains of old dead branches left in the dark hard knots; the age of the tree in its rings; the double heart signifying a breakage at one time of the original stem; the effect of varying degrees of heat and cold, of climatic conditions, and of severe or more propitious seasons, as evidenced by the broad, expanded rings and the narrow, compressed, less visible ones. It is only the approximate age that we find. A tree is at least as old as the number of its rings, but I have reckoned the age of tiny 
suppressed balsam seedlings, for example, with the microscope, and found that it had taken thirty years for their tips to reach the level of a two foot stump, so that, the shape of the stems being of course conical, the rings below the height at which the saw was entered would therefore not show on the tree's cross-section. This unknown quantity will vary, of course, with the different species, and with the location and exposure; we must know our tree before we can judge it. Then, again, if the crown is scragly in old age, or narrow, and hence in an unfavorable season might not be able to assimilate enough material to form a new encircling woody sheath extending along the entire length of the tree below, the actual age would perhaps be a few years greater than the number of rings at the stump. Thus, in one instance, I personally counted the rings at both ends of a fourteen foot $\log$ and found them at each end the same (2 I 4 years), which would ordinarily indicate that the tree had shot up in a single season more than fourteen feet in height, a presumption on its face absurd, and still more impossible considering the evident slow growth of the tree, the rings being so closely crowded that I had to use a microscope to see the separate lines. Then, too, there is frequently decay in the center at the butt, and that (no matter how little) will have depleted the years it has reached. If the growth, too, is greater on one side than the other (and it will generally be to the south, on account of the entrance of more sunlight from that quarter), there will often be two woody layers, close together, for but one year's increase, the first attempt having perhaps been retarded by a cold snap later in the season. I 
have often noticed this peculiar tendency in the birches, especially where a large root has had exceptional moisture, but it will also occasionally be met with in the case of apple-trees in orchards. Rings crowded closely together may indicate also unusually hard winters, or the lack of sufficient rainfall for several continued seasons (and this has often been tested from the rings by the memories of the oldest inhabitants, and the story of the trees has been found a true one), or the denuding of the foliage by fire or insects, in which cases it would of course take the tree some years to restore its normal annual increase through the leaves. A scar in the interior of a tree, say on a ring eighty years from the bark, may be an old blaze from the trails of the frontier, or, if it is continued throughout the successive $\log$ sections at the same ring (as I have seen it), is perhaps the tale of a lightning streak, or another tree, in falling, may have broken a branch from this one and stripped a long streamer of the bark off with it, this wound of former days having long since been shut in and healed over by the newer growth. If the tree be a maple, we may perhaps find a small cavity inclosed far in the wood, an evidence of some old-time tapping of years ago, which had been grown over and left there, yet even now to witness of its origin by the spiral ribs of the auger. It brings along with it all the long train of memories of the sugar camp, and of the humor and "sparking" of the best times in the world, the hours spent about the fire when the sap is boiling. And so these disks of the logs, can we but interpret them, are a record of the tree's life, invisible and buried while 


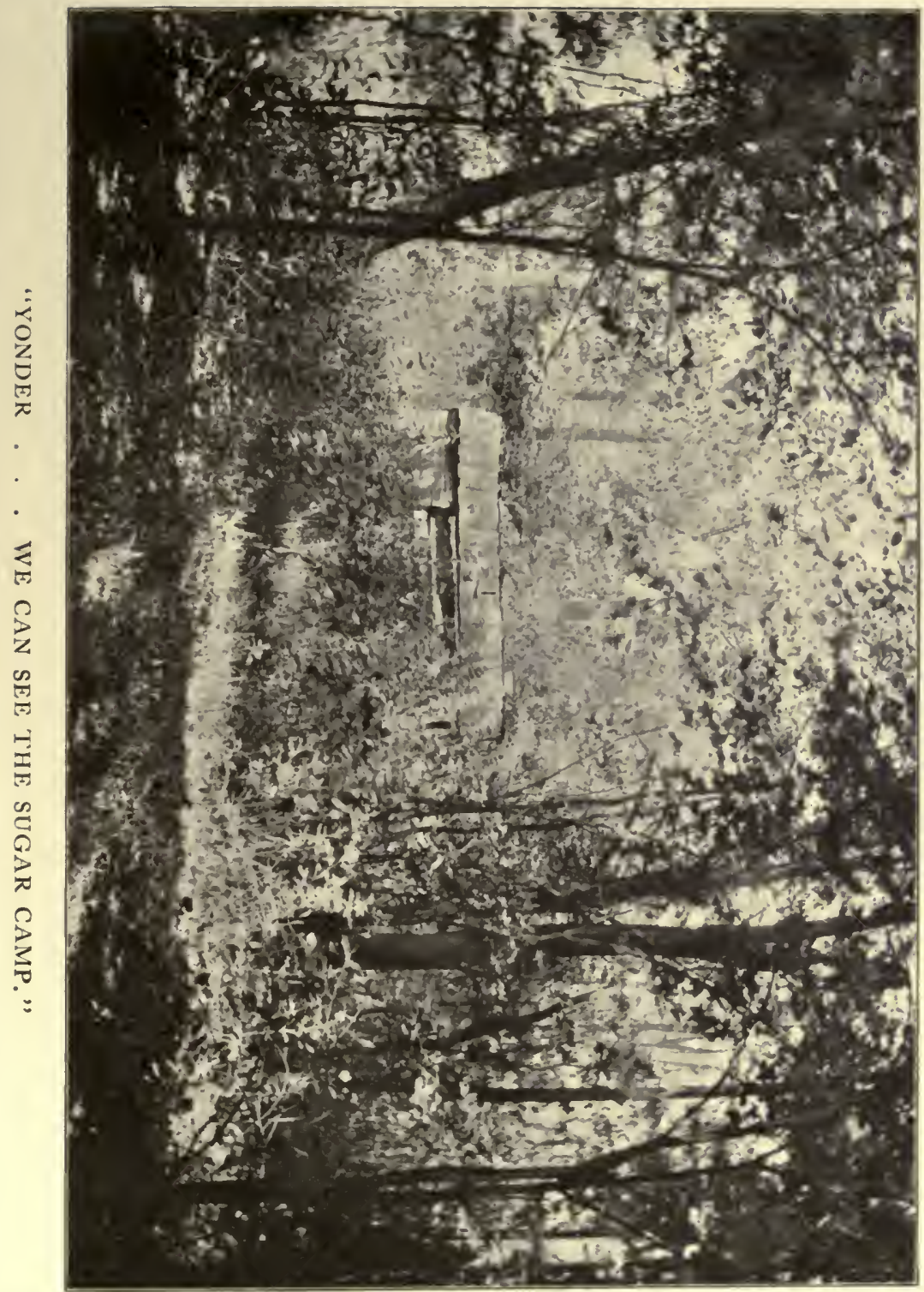



the tree stands, but ineffaceable and permanent as long as the wood lasts and is not decayed.

Yonder, near the light of a clearing, we can see the sugar camp now. It is the most romantic nook in the woods. A path leads to it from tree to tree, issuing at last in the camp, and a sled road winds about through the bush. The camp harmonizes well with the woods, being made largely of logs and poles with the bark still on, picturesquely put together by supporting crotches with the fine instinct and art of the true woodsman. Beneath its sheltering roof each year are put to test in the right season all the old-time, and the best, ways of making maple syrup, and the great kettles boil and simmer many a long night, while merry are the laughter and sport under the stars.

I have chopped into trees at the sides of old blazes, in order to see how many years of growth it had taken to cover them, and it is always an interesting experiment. Some that I investigated had been there over fifty years, and were yet discernible; some, less. I have heard of a tree in a well-known locality that was cut into for this very purpose, in order to ascertain the age of old blazes supposed to have been made upon it and to be shut in within the wood, and marks of the ax were found two hundred years back, gashed there long ago by Indians, as the traditions of the place asserted. Lauder, in one of his notes to Gilpin's "Forest Scenery," says that there are also on record instances of "curious discoveries" made in the felling of some trees in England toward the close of the eighteenth century, such as the marks of the cyphers of James I, William and Mary, and King John (thus denoting the reign when 
the letters were stamped), far on the inside, a foot, nine inches, and eighteen inches respectively within the trees, and dating, of course, long before their downfall.

I have also followed up the oid lines of some of the first government surveys in the West, the blazes of which were forty-five years of age and over; and it was not always easy to distinguish the scars of the bruises and scrapings, left perhaps by one tree falling against another, from the original blazes, so indistinct had these become in the years. In many cases the only way by which we could with certainty recognize the blaze from a scar was by the faint score marks of the ax still visible in the wood, or by the fact that the edges of the blaze on the bark would always be smooth where the ax had shaved into the tree, and not rough and uneven, as in a scar. A line tree, too, will almost always be blazed on both sides, and there will be others in a continuous direction near it, whereas a tree is seldom similarly bruised on both sides, and there are in any event not many such in a straight course. It was very interesting to rediscover and restore these lines through the woods. The figures of the section, range, and township could still be seen on the corner trees, half a foot or more inside the tree, on the face of the old blaze, almost hidden now by bark and the increase of new wood bulging in at the sides. I have also traced and reblazed with fresh slashes of the ax, for my own use, old trails through the forest, made by the Indians who had lived there or by hunters and trappers. I think a beech holds a blaze the longest of any of the trees, and is the best to use on that account, if on the line, and the easiest for the ax. It is the one most fre- 
quently blazed by old woodsmen. A beech, however, for some reason, has, singularly, more bruises and distorted growths on its bark than any other tree, and these curious distortions frequently resemble a blaze; but the bark ordinarily is smooth, while the maple, which otherwise shows the blaze quite well, has such rough, flaky, uneven bark that after some years' growth the old strokes of the ax become too indistinct for a ready sight. It is decidedly an exhilarating experience to blaze one's way into the wilderness, and then to retrace the line of yellow patches through the darkening forest; and you will have done your work well if you shall not at some time behind the leaves lose sight of the trail for an instant before you reach camp.

What a tangle a big tree is that has fallen by the wind or from decay! Great weeds grow up among the dead limbs and branches, and sough in the wind's wild requiem; and the whole of it has a look of age. The bark scales off, and the old wood beneath it is filled with ants and borers, and its surface is furrowed and scrawled over and criss-crossed with the wandering paths of insects worn in channels into it-the familiar hieroglyphics of Nature.

And the old logs-how long have they been there, lying in the sunlight and shadow and under the snow, decaying through the years, and enriching the soil with the best of fertility? What chance of wind or storm or old age brought them to the ground? Or perhaps the misfortune of being a bee or a 'coon tree was the cause of their downfall, or a fellow monarch, in the felling, may have brought another with itself to the earth. Hunters, perhaps, have rested upon it, with a 
fire close at hand and a brace of squirrels hung on a sapling, or it may have been the retreat for children on a picnic. And now, finally, mosses and lichens encircle it with a mantle of green and velvet, and ferns-the tresses of the wilderness-are springing from it and beautifying the woods with their delicate fringes and graceful, tender lacework.

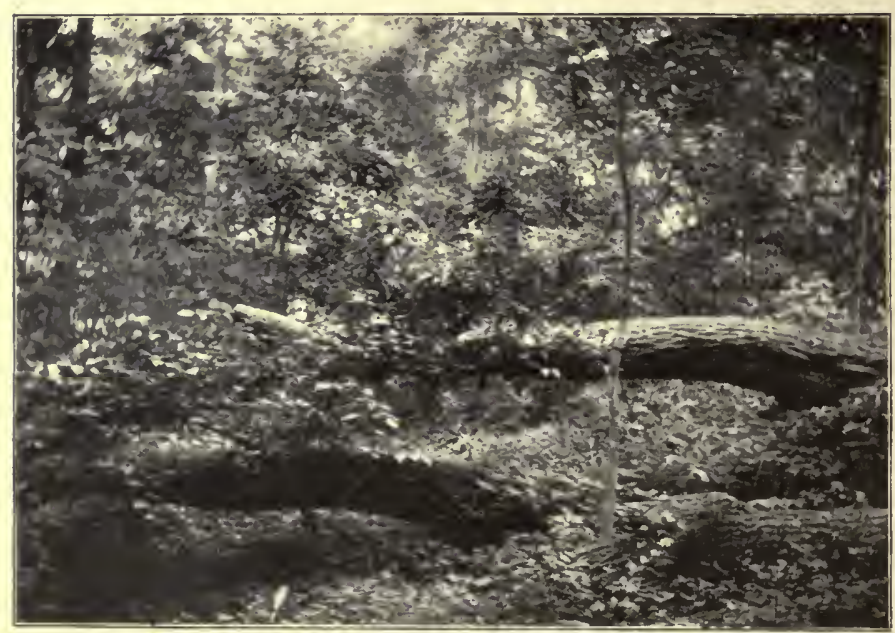

A Prostrate MONaRCH.

There is no sound in Nature more majestic and impressive than the fall of one of these massive monarchs of the forest. One can get a hint of its tottering by the swaying of the tops. Soon-in a moment-a deep shriek is heard as it splits from the stump, and is wrenched away finally, cut off perchance by the ax or saw; and a loud cr-r-rash, as it tears its way with a reluctant swish through the branches of those trees nearest it, and rushes toward the ground, losing some of its 


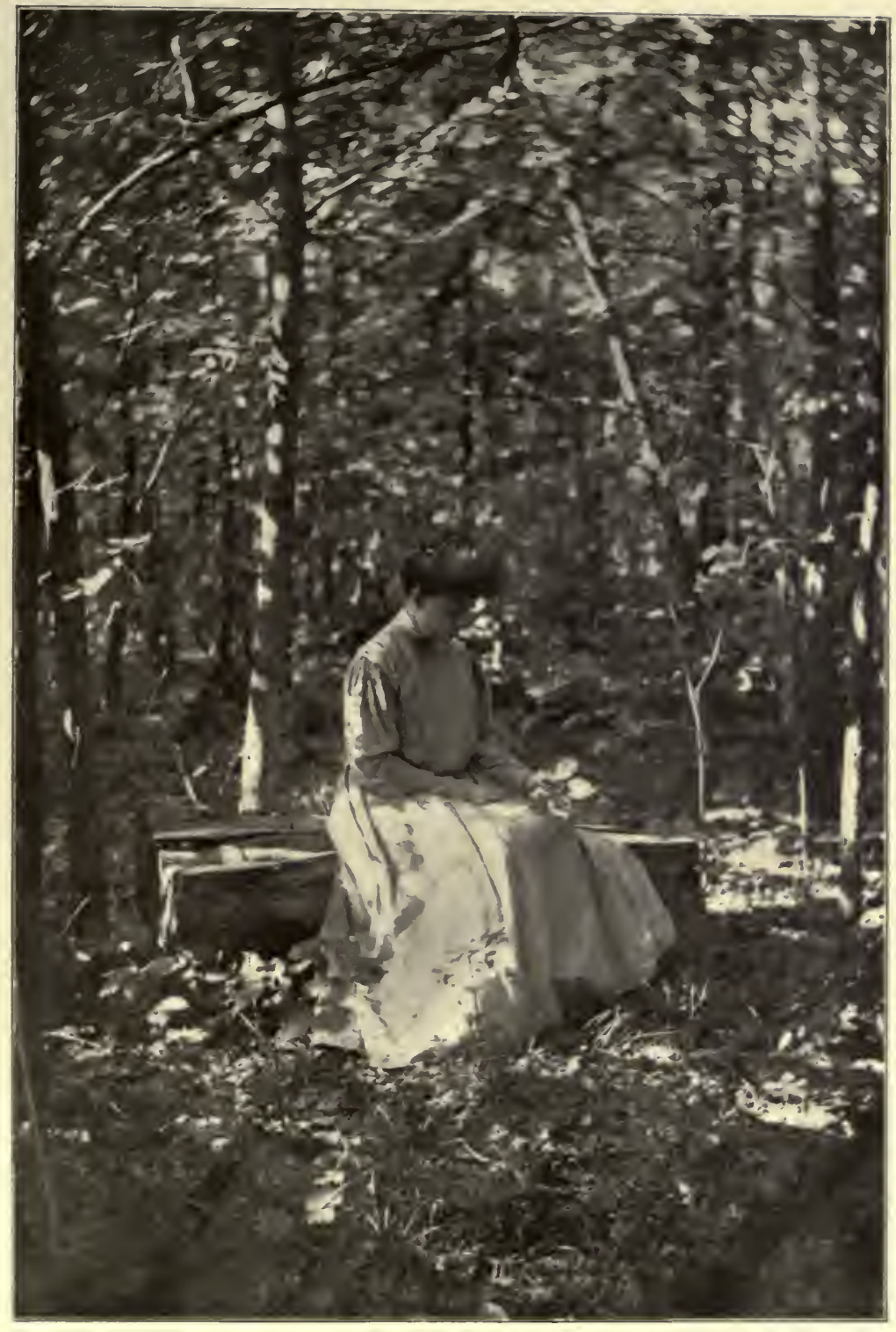

A SEAT IN THE FOREST. 

own limbs perhaps in the descent; and then, at last, plunges headlong to the earth, with a thud and a great muffled boom heard miles away! Homer felt the majesty of it centuries ago, and one of his finest similes likens the death of Hector to the downfall of an oak. A man can, it is true, in this way, by a few strokes of the ax, undo forever the long, slow work of a hundred years. Yet, in its place and within decent restriction, there is no pleasanter labor than work in the woods, especially beneath the leaves of autumn, in the cool of the year; and there is no rude music more attractive to the ear than the echoed chopping of an ax and the ring and rasp of the crosscut saw.

Thoreau, in "The Maine Woods," speaks of the sound of a tree falling in a dense forest on a still night as being "singularly grand and impressive," and thus describes it:

"Once, when Joe had called again, and we were listening for moose, we heard, come faintly echoing, or creeping from afar, through the moss-clad aisles, a dull, dry, rushing sound, with a solid core to it, yet as if half smothered under the grasp of the luxuriant and fungus-like forest, like the shutting of a door in some distant entry of the damp and shaggy wilderness. If we had not been there, no mortal had heard it. When we asked Joe in a whisper what it was, he answered, "Tree fall.'"

Sometimes stones, even large rocks, will be found almost totally concealed within the trees, having been lodged there somehow in the past and been grown over by the steady accretion of the years. I have seen rocks of some size absolutely imbedded among the roots of a great oak, which had wound its huge roots around 
and around their mossy surfaces until they were entwined within a very network of the woody, veins. Or

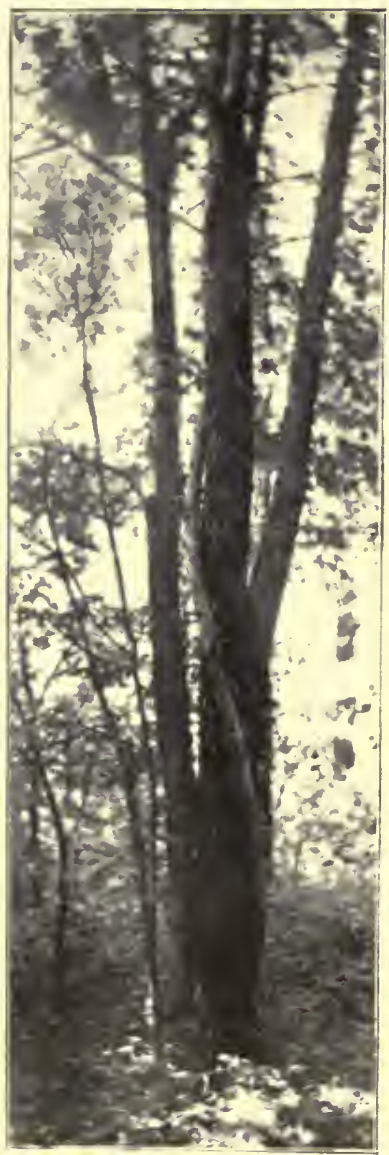

TWISTED TREES. perhaps a seed has fallen into a crevice or onto a little ledge of rock, and has there sent out its roots into the air, and these, reaching down toward the moist earth, have encircled the rock, and gripped it, and at last have wrapped about it with all the strength of the years, while the stem of the tree towers above and the rock is completely imprisoned and enfolded within the giant arms. I have known of boys who have placed stones of considerable dimension in the crotches of trees, some feet from the ground, and then have watched with delight the gradual but none the less firm encroachment of the bark about them as they finally became set in the wood, much to the wonder and astonishment of those not acquainted with this mysterious working of Nature. I have known also of others, and these not always so young, who have taken especial delight in the twisting, or braiding, of two small adjoining saplings with each other, so that they might become in the future a veritable mystery among the growths of Nature; and I have seen trees of a good girth which had so been entwined in their youth, and 


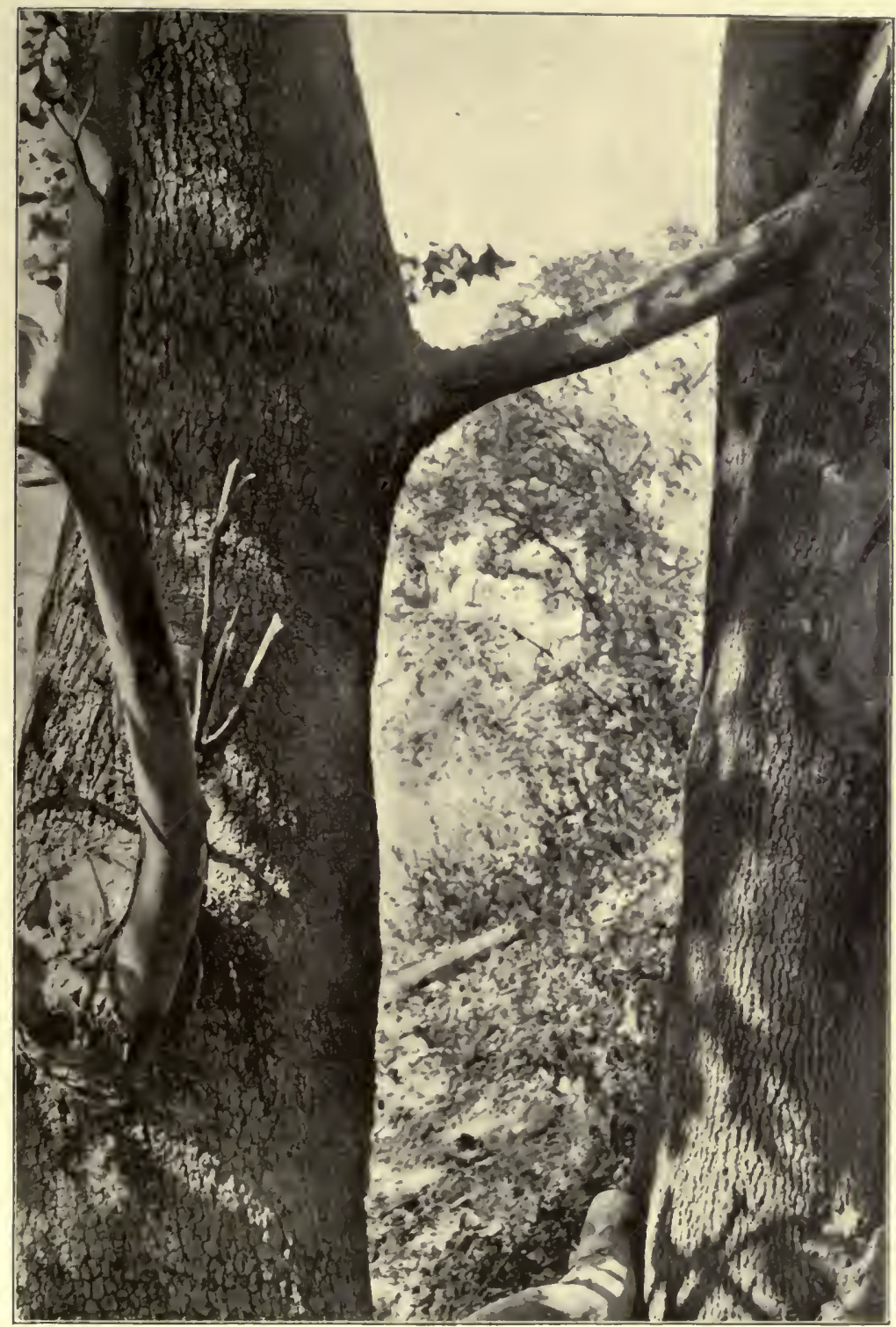

UNITED SYCAMORES. 

in their old age were not divided. If, too, in a dense thicket of growth, one branch shall closely press against another, by the constant rubbing and scarifying of the bark by the wind and the consequent irritating stimulus toward a bulging of the bark at the wound, trees of the same species will rarely join their arms together, twinlike, thus singularly uniting themselves into one tree, but I have never seen the cicatrix completed with trees of a different sap.

I know of a row of great elm s, planted in memory of a Revolutionary soldier, in whose sides large iron staples were driven, with rings in them, for the hitching of horses; and these have now altogether been e n m e shed

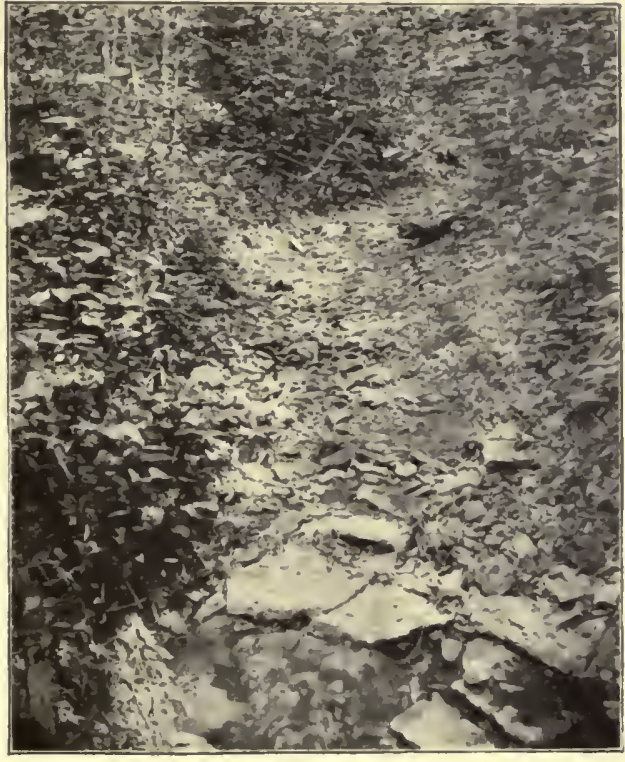

"ALONG THE BROOKS." within the trees, a few eyes, or dents, in the bark being the only external indication of their presence.

Perhaps you will come across in your work an old fire scar at the butt of a tree, now healed over by the slow process of the rings, pretty well covered by the newer growth and well hidden from the outside, and yet showing that some one had been there years ago, 
perhaps an Indian burning the forest for game, or a solitary hunter or trapper, or an emigrant who had camped for the night. Rarely a deer lick may yet be found in the pastures, and the cattle resort thither in springtime to get, as best they can, the last lingering vestiges of the original salty flavor. Old flint arrowheads, too, concealed beneath the matted leaves, but found occasionally on the slopes, tell the tale of the red man, while along the brooks, amongst the limestone shelving ledges, brachiopods and the various shells speak to us of a still more distant past.

There used to be a big hollow tree, so runs tradition, somewhere in the woods in this region of the Great Miami, in which wild turkeys held carnival and had their nests; and the pioneer would follow the sound of their calling, and perhaps find his concealment in the tree, and with his pipestem whistle the game back to him. There is an old story, too, still extant, that an Indian used to hide in this tree and imitate the notes of the bird, by this allurement decoying settlers sometimes to their death; but that the savage himself met a bullet in his ambush from some pioneer rifleman hid in the brush, and, leaping out from his concealment, fell dead to the ground below.

It was not so far away, in another woods, that a farmer, while cutting his fuel, found a number of bullets imbedded in a mass in the very center of a limb, having been shot there, as he supposed, at a knot or a squirrel, and then covered over by the new growth of the later years. Doubtless pounds of lead might be found in the branches and trunks of the trees hereabouts, could we but dig it out, sent there by generation after generation of hunters. 
A good many familiar trees have disappeared from the old woods. I was out the other day, and could not but notice the absence of some of those most fondly cherished-gone forever; as

$$
\begin{aligned}
& \text { "when some fond and spiritual bell } \\
& \text { Tolled in the memory, ceases." }
\end{aligned}
$$

The big pignut is gone, the tallest tree in the woods, together with some of the largest hickories and oaks, and the beeches with initials cut upon them long ago,all made over into saw logs, or blown down by the storms, or cut into wood for the winter fire. Some of the big black walnuts, however, under which the boys studied their lessons in former days, have now been made into valued furniture: as into decorative mantels; or into polished tables, at one of which I daily break my fast; but one, especially, that I think of, into an exquisitely hand-carved Shakespeare cabinet, adorned, in delicately wrought relief, upon its doors, with carvings of the hawthorne and a sprig of oak from Windsor Woods, and its sides modeled with Puck's and Perdita's flowers, with a scrolled inscription of Ophelia's saying, "There's rosemary, that's for remembrance; . . . there is pansies, that's for thoughts," in surface work upon its face, and paintings of 'Touchstone and Audrey in the Forest of Arden on its panels-the whole surmounted with Shakespeare's bust, and the cabinet itself being the repository of valued Shakespearean relics, with many sets of his plays, and various books and lives relating to his work. Thus the old woods has contributed to the refinements and rsthetics and amenities of life, as well as to the living necessities of lumber and fuel. 


\section{$15^{6}$ AROUND AN OLD HOMESTEAD.}

Many a pedestrian, also, in a stroll through it, has cut for himself a handsome staff or a cane. The hickories have always been with us the favorites for this purpose, for their strength and the nice, straight char-

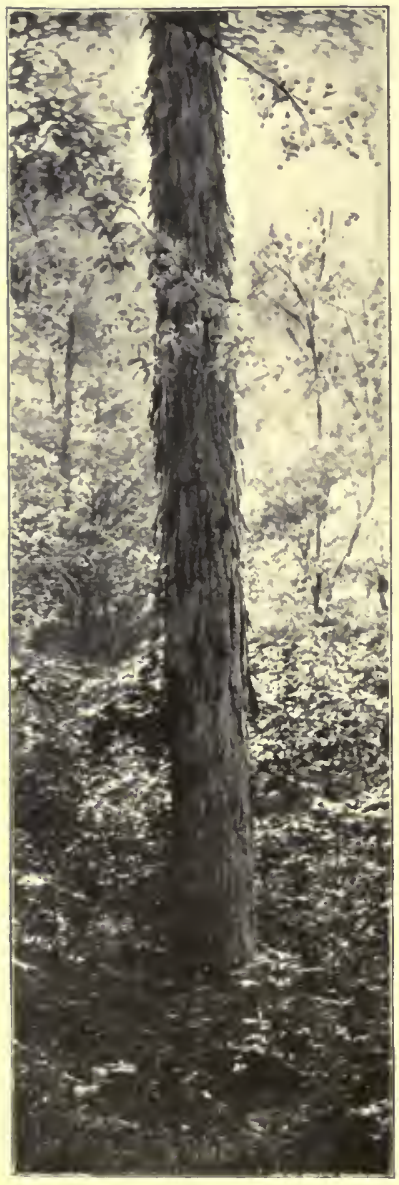

"THE OLD HOME TREE." acter of the saplings, and because of the undeviating adherence of the household to the tenets of Andrew Jackson-"Old Hickory" himself.

Some of the trees, too, have died, but are yet standing, and still others have leafless, dying branches at their tops (killed perhaps by the bullets), and these spikes and spreading staghorns of dead limbs jutting up above the green crowns are an unfailing sign of the beginning of the death of the trees. First the tops decay, and then the larger branches and limbs, and finally the trunk; and it is not so many years after these stagheads first appear when you will find the tree dead and vines twining in a living wreath about it. I felt the saddest when I found that there were staghorns on "the old home tree." It was a fine large hickory in the very center of the woods, which seemed to be a never-failing rendezvous for squirrels; for, whenever squirrels were not to be seen or heard anywhere else in the whole woods, if we would 
only repair to it we would always find them on "the old home tree." It apparently led a charmed life, however, like General Washington, for I never could get a squirrel from it, though I have shot them in all the other trees around it. The older trees will not last more than a hundred years longer, at the utmost; but the woods will renew itself, for the undergrowth of saplings is enough for a forest. Innumerable tiny seedlings - of maple, beech, oak, ash, and all the other trees in the woods-dot the ground everywhither beneath their elder brothers, themselves also in time to grow into magnificent tossing veterans, and finally to lie a-moldering in the sod. But a part of the virgin woods remains, at any rate, and the beauty and lurking wonder of its paths are even more precious in these days of ruthless destruction. There are still sufficient sugar-trees left to make maple syrup for this generation.

The old woods, in its way, helps along the rainfall by its constant diffusion of moisture; instead of letting it run off immediately into the brooks and thus swell and flood the rivers, it retains the wet in the soil, as it percolates through the fallen leaves and among the roots; it acts as a splendid wind-break for the homestead; in spring it shields innumerable wild flowers; in the summer bees drone away about the trunks; in autumn it sheds abroad the yellow and scarlet of its frosted leaves, and squirrels frisk among the hickories; and in winter its carpet of snow is dotted with the tracks of rabbits that have nestled in its logs, while the farmer drives his sled up the pathway piled high with seasoned wood for the great fireplace. New sap- 


\section{$1 ; 8$}

AROLND AN OLD HOMESTEAD.

lings are growing up everywhere, and shoots from the old stumps are always sprouting up into the light, to perpetuate its usefulness and to form another forest,

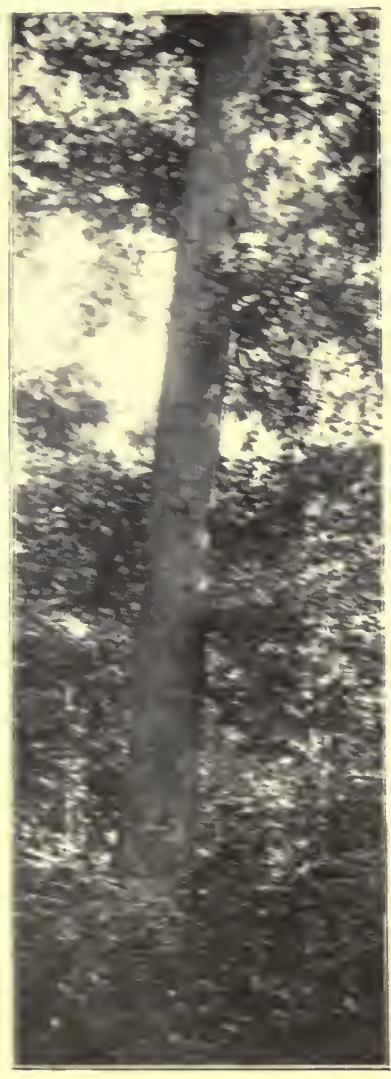

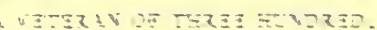

when this shall have gone into decay or shall have been cut down for man's utility. What would we do without the old woods? IThat a vast product the forest is-these immense tree growths, and their tough, fibrous stems and leafy canopies-made over into a serviceable form br the lumberman, and to be preserved and studied by the forester; and yet existing. after all, not for man's enjovment alone, but for the well-being of all the life about us! And does not this old woods, in its little usefulness to us, typify our larger beles of imber everywhere all over this broad land?

I am impressed with the age of the trees. Centuries it has taken to elevate them to their proud position, and some will last a century longer, even when cut fom and maje over into userul lumber. Some of the bizoaks lately ielled in the woods were over three hundred years of age. One of the large elms was ratiy as old. Ancil have been in the Adtrondacks.

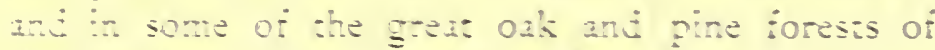
ite South and West and have found the trees eren 
older than this, and still sound. The bemlocks especially, when the growith had been rert gradual, the tree having been suppressed by the preponderance of shade on the part of the larger giants about it, were still perfectly bealthr: while the dominant trees surrounding. which had, on accowent of their enhindered enjorment of light, realized a much greater beight and a rasch wider diameter increase, had either begun to decar after their maturity had come, or. their orertopping branches having been caught in the wiods, had been blown down to make room for orthers sounger. But there it is, the recond of the pears, in the logs. There ther have stood for hundreds of years, these moody organisms, while generation after generation of men, from the Indian to the pioneer. and from the setder to the manufacturer, have passed beneath their sheltering roof and made use of the best of them. Behold them in their august majest, as ther swar. and swarthe trees!- -those serried. furrowed, improsing trunks. with their enormous waves of tossing. Billon! green? I have counted the rings of trees which were here and were of fair size, when Columbus irst came to the New World. and the sequoias of the West are as old as the prramids and have seem in their wrild forest life the whole histors of the Christian era.

Brrant"s lines in "A Forest Hrma" have come to mr thought. Let os read them:

"Mr heer is zwed within me witues I think Ot the prear mirache tha sill gos an. in suleace, roumd me- he grerpecul wat Ot tis creation. thished. ver tenowed

Forever. Wisten an it wokt I read

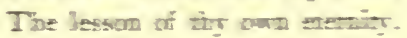


Lo! all grow old and die-but see again, How on the faltering footsteps of decay Youth presses-ever gay and beautiful youth In all its beautiful forms."

A woods suggests everything that is poetic. It is teeming with all sorts of life; it gives forth the purest oxygen; it is a bower of greenness in summer, and of beautiful darker colors in autumn. One feels always in health when in the woods, and to be able to feel a love for the woods is a pretty sure indication of a sound and healthy life.

Yet there is much difference in the attitude of men toward trees and toward a forest. The worth of a tree to some men is its commercial value in merchantable lumber, and a forest therefore is to be considered in the light of finance; to others a tree is an object merely of scientific investigation as a part of the progress of natural selection; to still others it is of intense interest as a preserver of shade and health, and its growth is to be studied, and the growth and variation of forests also, with a view to the preservation of our timber and the introduction of suitable tree plantations, and thus the conservation of our water supply and the betterment of life; to the farmer it is of immediate utility for all the usages of his farm; by the hunter it is regarded with mystery and constant observation as the probable lurking place of game; to many it is an object of wonderful natural beauty, and a spot for all sorts of legends and associations; while to others still it is an emblem of the tree of life, and of the river which forever floweth in the City of God.

The farmer, especially, gathers his firewood and gets his maple syrup and sugar from the trees, handles 
for his mauls and axes, fence rails, stakes, posts, poles for odd uses generally, beech leaves for his bed ticks, nuts and bright leaves in autumn, and wild flowers almost all the year round. Indeed, a farm without a wood lot is deprived of much that makes country life attractive and possible.

The most majestic living organism is a tree. Did you ever think how large a tree is? We seldom think of them as being very large; and yet the wood contained in the trunk and branches of a single beech or maple takes up vastly more space than does the body of a man, and their green leaves, if placed side by side, would occupy half an acre. It has been estimated that a good-sized maple with thick tops will put forth over four hundred thousand leaves in a single year. Yet we do not fear the trees, but we enjoy their shade and color in their lives, gather their fruit in its season, and, when they die, or even before, little man, with his powerful mind, saws and chops them up for fuel and lumber, and sends them into all parts of the world and for all purposes.

A tree, too, is always graceful. Even when some of its branches are stripped off or broken, it will not submit to such a deformity, but will send out new shoots to take their place, which will soon grow and thrive in towering masses of green or depend in drooping, delicate sprays, thus even in its misfortune shaping to itself again a characteristic symmetry of form. So each one also, and especially when in leaf, displays its natural qualities of contour, from the tented, pagodalike appearance of the horse-chestnuts on the lawn to the plume-like, feathery ferns of the elms. 
A tree!-its mossy roots and taproots buttressing that part of it above the ground; its tiny rootlets and root hairs penetrating into the interstices of the soil and there finding life, almost feeling their way, one might think, with a sense of touch, and pushing aside the diminutive clods to make a place for it to absorb and assimilate moisture for its growth; the great tough woody stem, or trunk, acting as a support for the whole and spreading aloft into God's sunlight and air, covered with rough bark, the home of myriads of insects and of other animal and plant life, and finally expanding into a multitude of strong arms and an infinite, fern-like, fingery penciling of branches and twigs; these clothed in a beautiful canopy of green leaves, with the most delicate and exquisite venation, toying with the air, breathing in life for the tree and exhaling life for us-ah! surely Ruskin was right when he said, "What a wonderful thought of God was that when He thought a tree!"

How much there is in a tree that is of interest and perennial delight! What caused those little scratches on the bark? Birds, or squirrels? Or perhaps 'coons? And where have they gone, or do they still live in the old tree? Where are the innumerable ants going, and is the old tree a regular honeycomb of their tunnels and trails? How furrowed the bark is, and how aged it looks! Its branches, too, doubtless have a few birds in them now, that we can not see because of the leaves, and perhaps more than one nest is concealed amid its great growth of twigs. A large tree, in its time, may have been the home of two or three kinds of squirrels, say of a dozen families of birds, of 'possums and 'coons, 
of lizards, of snakes and ants at its roots, and with perhaps a screech owl in a hollow limb. It will also have been the life of fungi and of mosses, and the home of many insects, and of old grubs and borers. A tree which is at all old is a veritable mine for speculation. And, when it dies, it is cut down, and gives warmth to the farmhouse in the winter fire, after perhaps a hundred years or more of useful existence to the living world.

I am reminded, in this connection, of a passage that Thoreau has written, words that are among the most beautiful in the literature of Nature, at the close of his "Walden:"

"Every one has heard the story which has gone the rounds of New England, of a strong and beautiful bug which came out of the dry leaf of an old table of apple-tree wood, which had stood in a farmer's kitchen for sixty years, first in Connecticut, and afterwards in Massachusetts-from an egg deposited in the living tree many years earlier still, as appeared by counting the annual layers beyond it; which was heard gnawing out for several weeks, hatched perchance by the heat of an urn. Who does not feel his faith in a resurrection and immortality strengthened by hearing of this? Who knows what beautiful and winged life, whose egg has been buried for ages under many concentric layers of woodenness in the dead, dry life of society, deposited at first in the alburnum of the green and living tree, which has been gradually converted into the semblance of its well-seasoned tomb-heard perchance gnawing out now for years by the astonished family of man, as they sat round the festive board-may unexpectedly come forth from amidst society's most trivial and handselled furniture, to enjoy its perfect summer life at last!" 
Does the tree enjoy its life? I have wondered. Some of the scientists tell us that its whole individuality is the result of external forces, over which, of course, it has no control, and by which it is molded. But yet they fail to account for the presence of life there, and where life is I think joy is also. I believe that the vine creeping up yon beech is alive, and that as it attaches itself to the bark with its feelers and tendrils it has a joy in existence. I believe that it loves the caresses and kisses of the air. Oh, it has no mind, I know, and hence, I suppose, no self-consciousness; but in the coiling spiral of the vine, so pliant, so responsive, so joyously obedient to the least influences of wind or tree, there surely resides an identity which is at once unique and soul-like, and it is fair and comely because it delights to be so. So far as it goes, in the scale of being, the life of plant and tree, bird, animal, and the forms of the ocean is just the same (do you not certainly think?) as is ours--only, of course, our life is much more perfect, more complex, more adaptable, and more appreciative. That there is a vast and real unity in Nature is not to be questioned. We, too, have a spiritual affinity with bird, beast, and flower. Thoreau, in his admiration, said of the pine-tree: "It is as immortal as I am, and perchance will go to as high a heaven, there to tower above me still."

There are few things in the woods more beautiful and graceful than a fresh spray of Virginia creeper, clasping close to an old rail fence or twining and hanging about an elm. In autumn, with its dense masses and its whorls of dark red leaves, it is one of Nature's master pictures. The old woods is full of it. In a few 


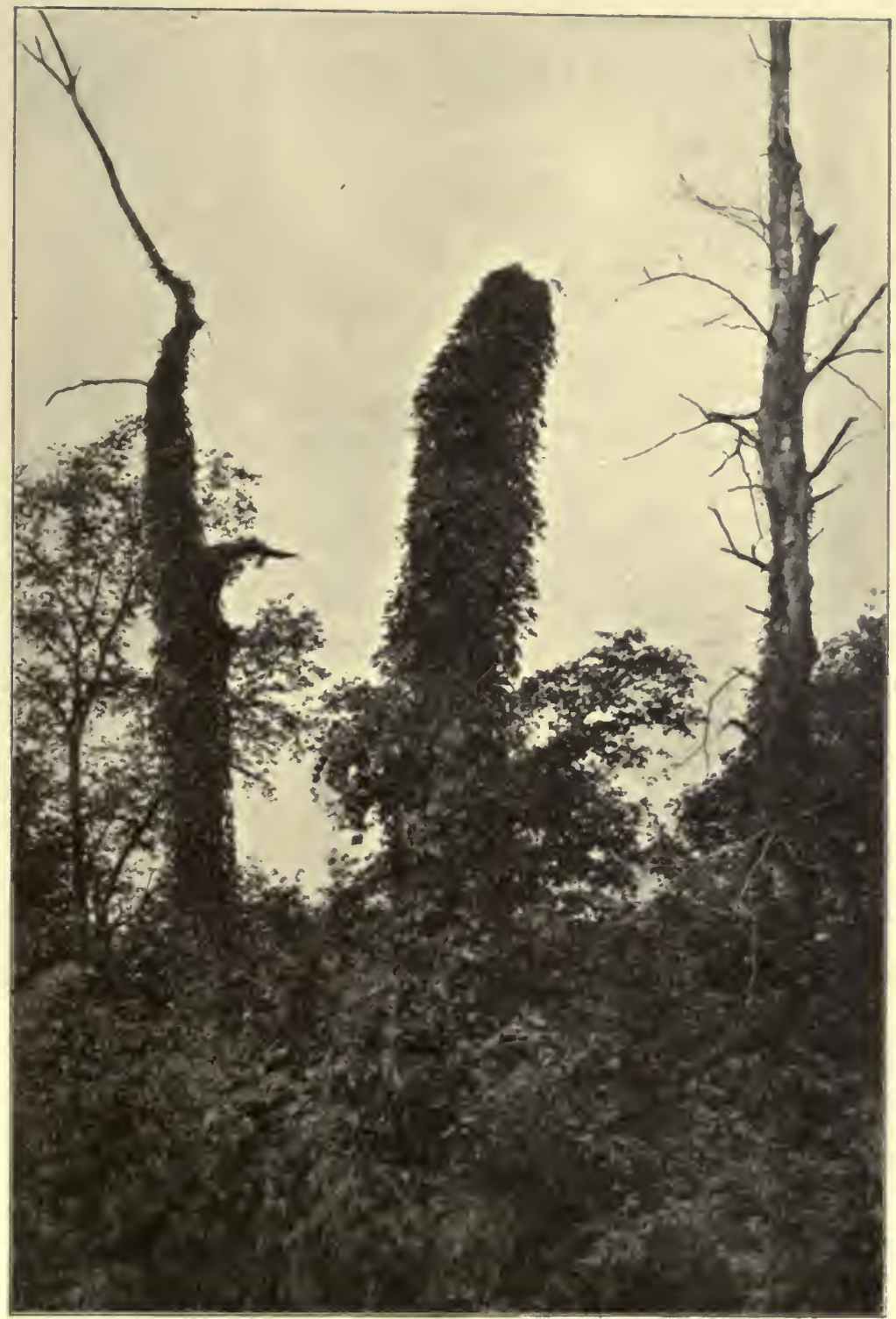

"WREATHED PILLARS OF LIVING GREEN." 

spots great beeches are wreathed pillars of living green, very picturesque indeed if seen at a distance through openings of vista between the trunks, like the ivied battlements of ancient ruins; elsewhere the vine trails along the ground, snake-like, across the matted leaves, or cushions the remains of some old prostrate veteran; in still other moods it clambers industriously over a young maple or a broadleaved mulberry, seeking even the outermost twigs everywhither, and nodding airly above them, in a canopy that affords a lovely, shady solitude, like the bowers formed by the wild grape.

The beeches are the most interesting of the trees. What huge limbs they have, sometimes all twisted and bent and gnarled together, and yet spreading and drooping finally into long, low. trailing, fan-like sprays - the eye lashes of the forest. Was it Thoreau who said that no tree had "so fine a bole or so fair an instep as the beech?" Gilpin, in describing the beech, says of its bark: "It is naturally of a dingy olive; but it is

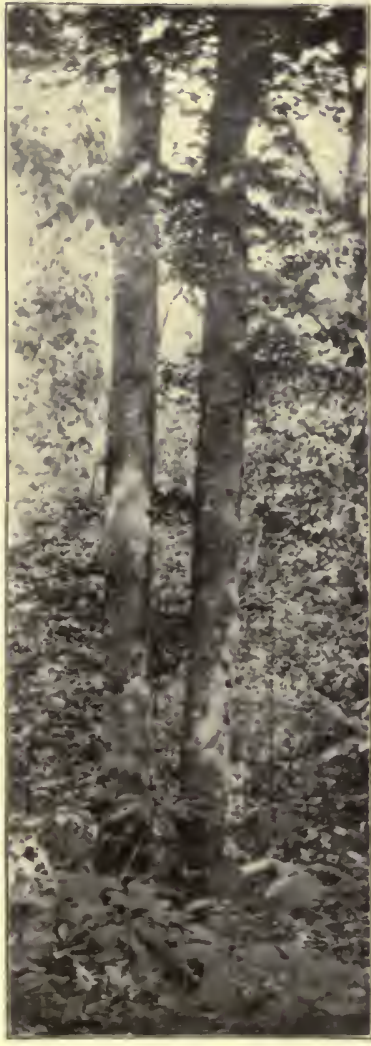

TWIN SISTERS. always overspread in patches with a variety of mosses and lichens, which are commonly of a lighter tint, in 
the upper parts, and of a deep velvet green toward the root." Somehow I always feel as if I were actually in a forest if there are only a few beeches. I used to enjoy in boyhood days swinging upon their great arms, the tips of which often would sweep the very earth, and to scramble amongst their branches, like a squirrel, after the nuts; yet I think nowadays it would be one of the hardest trees in the world to climb.

What is it that possesses men to carve their initials upon every suitable tree? Is it merely to record the fact of their presence on that spot, or a desire that their names shall be writ there for eternity? Or does the smoothness of the bark attract them? Whatever the reason, certain it is that he is an extraordinary man who with a jack-knife in his pocket will pass a good beech without first trying the blade, and leaving at least a part of his name as a witness to posterity of his having passed that way.

'T was not an uncommon propensity, it seems, centuries ago. Even as far back as the old Roman days do we find mention of this singular trait in human nature as being a characteristic of the Latin race. Hamerton quotes Vergil on the custom. In the tenth eclogue Gallus says:

"Certum est in silvis, inter spelaea ferarum Malle pati, tenerisque meos incidere aınores Arboribus : crescent illæ ; crescetis, amores."

("My mind is made up to prefer to suffer in the forests, among the dens of wild beasts, and to cut my loves upon the young trees: these will grow; ye will grow, too, 
THE WOODS. I69

ye loves" [i. e., the letters will increase with the size of the tree, as his feelings].) It has long been a means of letter-writing with savages. In his "History of Virginia, in Four Parts," published (second edition) in 1722, Thomas Beverley remarks, too, that it was learned by the next settlers "by Letters on the Trees," scratched there by earlier arrivals, that the latter had removed to Croatan, an island. Orlando you remember, in "As You Like

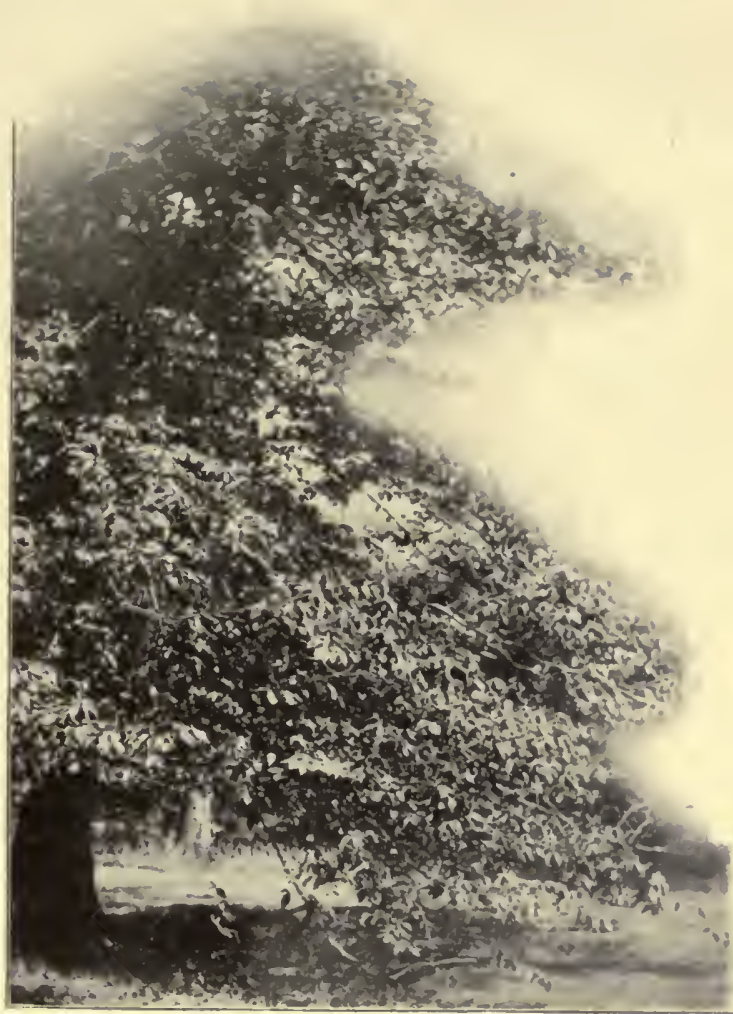

"THE EYELASHES OF THE FOREST." It," was so persistent in carving sweet Rosalind's name upon the trees and hanging verses from their boughs ("There is a man haunts the forest," said she to him) that Jaques was moved to remonstrate: "I pray you, mar no more trees with writing lovesongs in their barks." Sir Roger de Coverley, too, confessed that he "had been fool enough" to carve "the perverse widow's" name on several of his trees; "so unhappy is the condition of men in love, to attempt the removing of their passion by the methods which serve only to imprint it deeper." And here are some 
lines from an old poem, "The Beech Tree's Lament," by Thomas Campbell, uttered by the beech:

"Thrice twenty summers I have seen The sky grow bright, the forest green; And many a wintry wind have stood In bloomless, fruitless solitude, Since childhood in my pleasant bower First spent its sweet and sportive hour ;

Since youthful lovers in my shade Their vows of truth and rapture made; And on my trunk's surviving frame Carved many a long-forgotten name."

Who shall, asks Bryant also, speaking of his future forest,

"Who grave, as was the wont

Of simple, pastoral ages, on the rind

Of my smooth beeches some beloved name?"'

$\mathrm{A}$ beech is the best, and the tree most frequently chosen, on account of its smooth, easily-cut bark. It is the pleasantest and most yielding to the knife; and initials carved on a beech, if they have been dug deep into the sap wood beneath the bark, are retained much longer than on any other tree. "No bark," says Gilpin, "tempts the lover so much to make it the depository of his mistress's name." I have seen old beeches deeply scarred with the hieroglyphics of visitors, curiously crude, like Indian picture-writing, interwoven with the initials. In our boyhood enthusiasm, however, we did not restrict ourselves to beeches, nor even to trees, but our names were cut upon every available object around the farm- the well curb, trough, the timbers in the barn, the door, the beams, the feed-box, the 
big catalpa-tree, and the gate posts - and even a mapletree bears in its branches aloft somewhere the initials of two youngsters who one memorable night perched for hours among them-in order to get the last glimpse of an eclipse as the moon went down toward the western horizon. Sycamores and poplars $\mathrm{may}$ sometimes be made to serve the purpose quite well, in lieu of a beech, if the passion is upon one; and I have seen whole names shaped diligently into the rough, uneven bark of oaks and elms.

I like to look at these initials carved on the trees. The old inscriptions are in their way filled with the very spirit of the past. Many of those who put them here have gone far beyond into still h a p p i e r hunting grounds; but they once lived here below, and whether from affection or mere

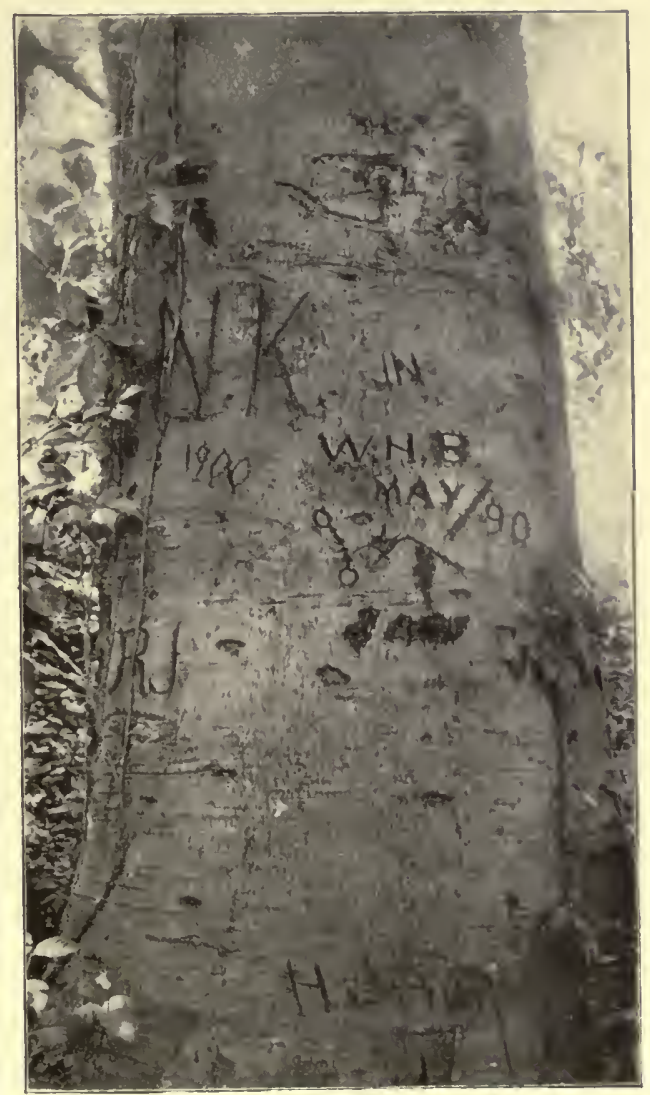

INITIALS AND HIEROGLYPHICS. 
whim, or for premeditated fame, they have left their names recorded. I have seen the date 1853 upon a beech, yet plain after fifty years. I recall also one other tree - this, too, a beech - with weatherworn initials upon it and the date 1864, the letters being not quite legible and the figures just barely discernible as such; and two other trees, with the years I 866 and i 867 upon them, still distinguishable, though the bark was cracked and spread apart, and the lettering consequently badly checkered. Mr. John Burroughs, in his essay on "Nature in England," in "Fresh Fields," speaks of the soft stones of the bridges and churches in England as being all carved up with initials, some of them over a century old. On Lookout Mountain an old mountaineer with whom I went deer hunting told me of a place a few miles from the road where the trees were literally lined and tattooed with bullets and initials put there by soldiers in the Civil War. They had camped on that spot for a time, and had left their names on many of the trees, and had used the trunks as a backstop in target practice; and, of course, one can frequently see evidences of the soldiers' presence in the old splintered stumps on other parts of the mountain, in which cannon-balls sometimes found their final lodgment.

But decidedly the most interesting script that I have yet seen anywhere in any woods is the writing of an English schoolmaster of this village, who lived for a time at the homestead, and whose wood-carving on the trees is therefore known to have been cut there long "befo' de wah." There were two fine large beeches in this woods which he chose as his favorites, to be the recording recipients of his feelings. Upon one of 
them, graven deeply in capitals, ran the following, which shows the pedagogue to have sighed like a furnace in his day as a lover:

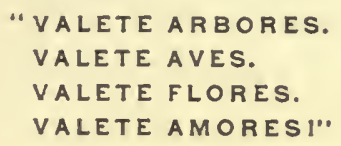

("Farewell, trees. Farewell, birds. Farewell, flowers. Farewell, loves!") And so the man had had his heartstrings touched by the little god, and had his loves to bid farewell to, as well as the trees, the birds, and the flowers; and this time, too, it was farewell forever. He was a singular man, and, although he taught in an obscure country district, he was well educated, and there was something of the real scholar to the man, as all testify who knew him. It was always thought, in surmise, that he had a history which he did not disclose-was perhaps a writer at work upon some book. It was his habit to wander through the old woods by the hour, reciting aloud stanzas and quotations in Latin, and nearer the homestead he himself had worn a path alone, up and down which he would take his endless beats and make his orations, casting meanwhile lance-like at some mark a few stiff stems of iron weed which he had collected. The other inscription, which encircled the tree in script, rings with patriotic sentiment, and suggests that perhaps the teacher even then felt a premonition of the impending war between the States; and so it reads:

"Cominus pugnamus pro patria et libertate e't non moriemur inulti."

("Together we fight for country and liberty, and 
we shall not die unavenged.") I have looked upon these quaint old Latin inscriptions with mingled feelings of kindliness and pathos. Written in the early '40's, they were still legible in 1897 , though the letters were somewhat grown over with new bark, and thus made distorted and spread apart and quite indistinct, and it was with some difficulty that I could make them out. But both trees were finally cut down, and sawed into lumber or split up for firewood, and the singular old schoolmaster and his strange ways are now only a memory, coming dimly through the trees out of the far-away past.

Traps? The old woods was full of them. All sorts of snares were cunningly devised with which to beguile the unsuspecting forest creatures. And the necessity to make the rounds of the traps daily was frequently the occasion of a somewhat prolonged absence from the fields in corn-cutting or potato-digging time. No, we never caught anything in these twitch-ups, that I recall. But they were very excellent traps, and were constructed, somewhat after the manner of Izaak Walton's flies for fishing, of horsehair, cord, pieces of wire, and twine. We frequently found them sprung, and once there were actually a few hairs from a gray squirrel's tail left caught in a noose. The horsehairs we pulled and twitched from the tails of our humble beasts of burden, and their long silky tassels grew noticeably shaggy and ragged after part had been impressed into our service. As many as twenty-one quail at once were caught years ago, so the saying goes, in a big figure four trap, made by a Nimrod of the day, who has now grown into a gray-haired hunter and lover of the woods. 
Near by was the orchard. The trees were large and had a comfortable look to them, and the varieties were all the good, old-fashioned kinds which no new apples take the place of. We used to purloin the orchard occasionally on our squirrel hunts, and, with a few "roasting ears" from the cornfield and some hunks of bread from the pantry, we would feel like veritable kings of old beside our fire in the woods, munching our bread and apples, and watching the ears of corn smoke in the ashes, with a shy, proud glance now and then at the brace of squirrels lying on the $\log$ beside us and our faithful rifles leaning against the nearest tree. Leatherstocking, I know, never had such feelings of serene and absolute self-contentment and enjoyment of life as we at those early breakfasts under the hickories. We had found the thing worth living for. We were rivals of Robin Hood. Why, Daniel Boone himself had hunted and lived not more than a hundred miles away! I wish I could leave it in language, the wildness I have felt on those fresh mornings, in moist dingles among the waving grass and the beautiful swaying trees, while the gun barrel was beaded with dew; or in the late afternoons, when the great trunks were painted with the sunset lights and shadows; or again, when looking for 'coons beneath the stars and under the hunter's midnight moon.

The old woods-how I have loved it! The sweetest memories of life are entwined back there among the grasses and the grapevines and the oaks and beeches. Its beauty and silence and the wild life in it were the unsolved mystery of boyhood, and its deeper study 
in later years has been a very great delight and inspiration. I think I gain, by familiarity with its life, something of its vitality, at least in spirit. The long vista of the great trees, the sunshine mottling the leaves and filling the open spaces beneath with beautiful light, the immeasurable canopy and the shade, the birds singing their lores and their joys, the squirrels frisking among the acorns, and the atmosphere of age which pervades it, all have filled my mind with never-to-beforgotten impressions of the beauty and loveliness of the old woods, and a memory abides that is a perpetual dream.

I hear the low moo of a cow, feeding on the near-by blue grass. The silence echoes it. The flute-like notes of a wood thrush fall from the branches of a maple. As I listen, the sweet tones of Sabbath chimes come floating through the aisles of the trees. Fainter, fainter -as they wind through the forest and die away-so the sounds bring back past memories, which themselves drift and weave about the trunks, like mist, at last also to fade. far beyond, into the haze of a dim, happy, fond long-ago.

Adam was the first forester. "The Lord God took the man, and put him into the garden of Eden, to dress it and to keep it," even with the rude stone implements of those days of primitive man. Indeed, it would seem as if the care of trees, their pruning, culture, and fostering, was a divinely intended and natural occupation of mankind (as, too, it has always been one of the most congenial), man, besides, to subsist on the native fruits and nuts of the groves. Thus far have 


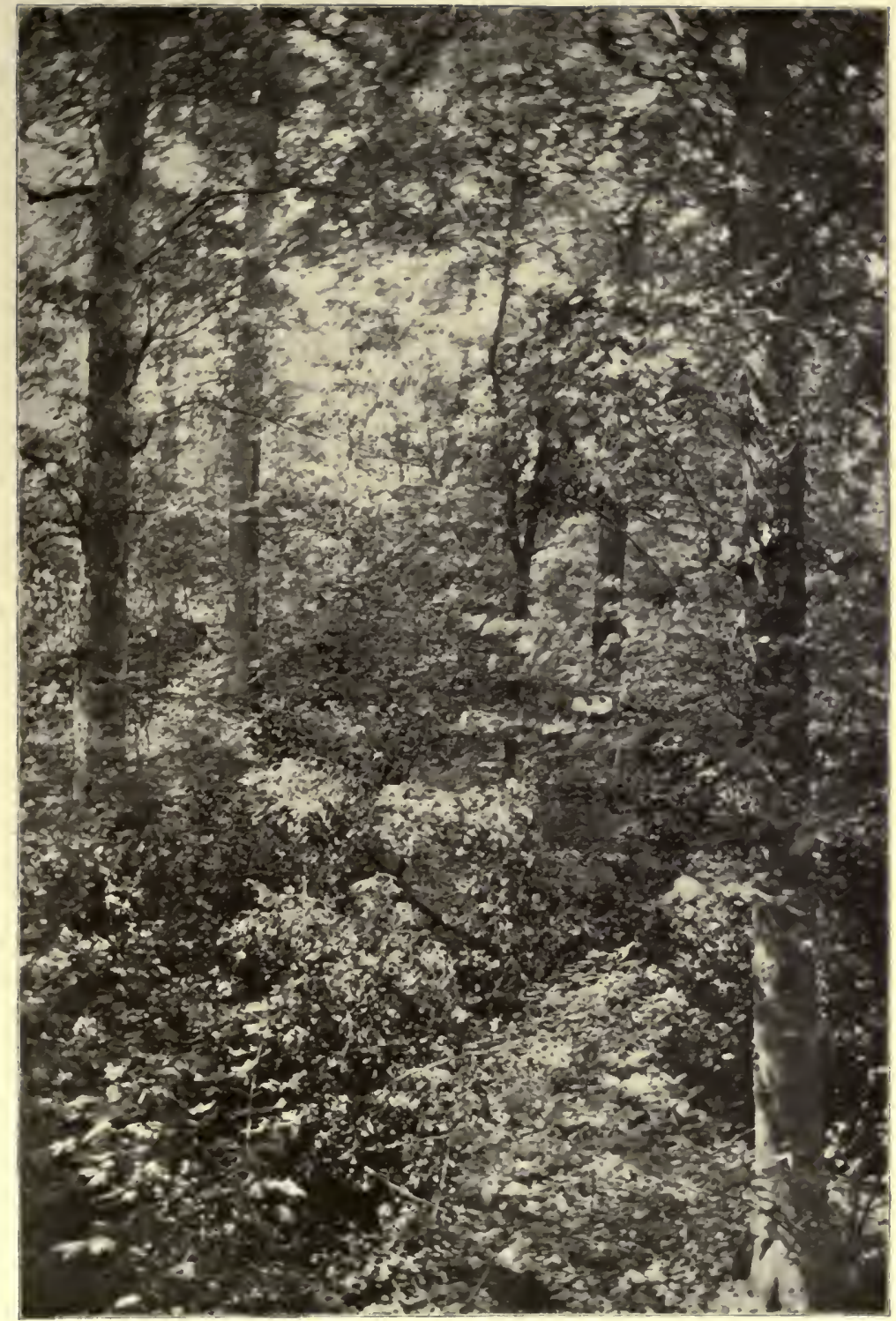

"'THE SUNSHINE MOTTLING THE LEAVES." 

we fallen and wandered, in that the herbs and fruits are no longer the only things that are "to us for food," and that man no longer spends all of his time amid the trees, nor does he always protect and preserve the virgin forests. Alas! the desire for money has in this instance as well as others been the root of all kinds of evil. Commercialism and poetry do not often agree; we sell our birthright for a mess of pottage. Yet, thus nurtured in his infancy in the forest, man has ever loved it, and has walked among these giant fern-like forms always, if involuntarily, with veneration-as if with the experiences and memories of past centuries still within him.

It is not for many of us to be like the barons of eld, and to behold deer cropping the grass in our own demesnes, or to look about our walls upon rows of mounted antlers, trophies of the chase. Nor shall we often feast royally upon venison before the logs in spacious manor halls, as is the picture in "Ivanhoe." Yet we all turn to the wild at times instinctively; and, can we but release for a moment this noble savagery from the surfeit of the too intricate and over-studied culture beneath which it now lies smothered, the woods shall still be unto us a home and an abiding place, and we shall again rejoice with Robin Hood and Little John to hear the bow twang and see the stag leap in Sherwood Forest.

For the forest, because of man's long joy of it, has found its way into literature. ' $T$ is there, at least, we may all seek it, and betake ourselves thither to rest in its shadows. Homer loved it; so did Vergil; and there are passages of forest description in the Bible which are 
magnificent for their language and beauty, such as occasional verses in Ezekiel and Isaiah, in which the trees are used as examples in the most exalted prophecies. Jehovah, through Isaiah (chapter lv, I 2 ; lx, I 3 ), says that "all the trees of the field shall clap their hands" at the return of the wicked, and thus portrays the future of Zion:

"The glory of Lebanon shall come unto thee, the fir-tree, the pine, and the box-tree together, to beautify the place of My sanctuary ; and I will make the place of My feet glorious."

The description of the cedar in Ezekiel (chapter xxi, 3-9) is especially to be noticed:

"Behold, the Assyrian was a cedar in Lebanon with fair branches, and with a forest-like shade, and of high stature; and its top was among the thick boughs. The waters nourished it, the deep made it grow. . . Therefore its stature was exalted above all the trees of the field; and its boughs were multiplied, and its branches became long by reason of many waters, when it shot them forth. All the birds of the heaven made their nests in its boughs; and under its branches did all the beasts of the field bring forth their young; and under its shadow dwelt all great nations. Thus was it fair in its greatness, in the length of its branches; for its root was by many waters. The cedars in the garden of God could not hide it; the fir-trees were not like its boughs, and the planetrees were not as its branches: nor was any tree in the garden of God like unto it in its beauty."

The cedar of Lebanon figures prominently all through the Scriptures; Solomon, indeed, had "fourscore thousand hewers in the mountains," felling cedar and fir for the temple. David, in a comparison, laments 
the unreasoning destruction of the forests in his day, when he says (Psalm lxxiv, 5, 6) of the enemies of Zion :

"They seemed as men that lifted up axes upon a thicket of trees. And now all the carved work thereof they break down with hatchet and hammers."

It was but natural that the singer of the twentythird Psalm should have hated to witness the devastation of the woods. Abraham's tent was pitched beneath the oaks of Mamre, in that far-off picture of Genesis, when he and Sarah refreshed their guests, and he stood near them as they ate, "under the tree." Adam first walked beneath the trees; the dove brought the leaf of an olive-tree to the ark; it was branches of trees which were strewn before Jesus at His entrance into Jerusalem; and the leaves of the tree of life, in John's concluding vision, are for the healing of the nations.

Even Dante, mediævalist though he was, felt the majesty of the forest. Ruskin said that Dante's description of his entrance into the Earthly Paradise, in "Il Purgatorio," was "the sweetest passage of wood description which exists in literature." Shall we read some from it?

"Fain now to search within and round about the divine forest dense and living, which tempered the new day to my eyes, without longer waiting I left the bank, taking the level ground very slowly, over the soil that everywhere breathes fragrance. A sweet breeze that had no variation in itself

${ }^{1}$ Using Norton's translation. 
struck me on the brow, not with heavier blow than a soft wind; at which the branches, readily trembling, all of them were bending to the quarter where the holy mountain casts its first shadow; yet not so far parted from their straightness, that the little birds among the tops would leave the practice of their every art; but with full joy singing they received the early breezes among the leaves, which kept a burden to their rhymes, such as gathers from bough to bough through the pine forest upon the shores of Chiassi, when Æolus lets forth Sirocco.

"Now had my slow steps carried me within the ancient wood so far that I could not see back to where I had entered it: and lo, a stream took from me further progress, which toward the left with its little waves was bending the grass that sprang upon its bank. . . .

"With feet I stayed, and with my eyes I passed to the other side of the streamlet, to gaze at the great variety of the fresh may; and there appeared to me, even as a thing appears suddenly which turns aside through wonder every other thought, a solitary lady, who was going along, singing, and culling flower from flower, wherewith all her path was painted."

Beautiful, indeed, is it not for those times?

The forest has been the scene of fairy revelry, of lores, of many a fight and kingly hunt. It was in a forest where Puck ran, and with Bottom created consternation, in "A Midsummer Night's Dream;" and, again, it was beneath the trees where "the melancholy Jaques" propounded his discourse on the seven ages. Shakespeare's forests are all historic-Falstaff and Herne's Oak; Touchstone and Audrey, and Rosalind, in the Forest of Arden; Macbeth and Birnam Wood. Spenser, too, knew the forest of his day, and reverenced it. No trees had yet died in Spenser's forest to 
let in the light for the seedlings to grow. Philip Gilbert Hamerton, who also loved a forest, speaks thus of him, in "The Sylvan Year:"

"Think what was Spenser's conception of a forest, and what in our time is too often the uninteresting reality! He thought of it as a country shaded by a great roof of green foliage, which was carried on massive stems always so far apart that one or several knights could ride everywhere without inconvenience; but we find the reality to be for the most part an impenetrable jungle of young trees, that will be cut down in a year or two for firewood."

Milton's imaginative Eden, too, is a very delightful forest picture:

\footnotetext{
"So on he fares, and to the border comes Of Eden, where delicious Paradise, Now nearer, crowns with her inclosure green, As with a rural mound, the champaign head Of a steep wilderness, whose hairy sides With thicket overgrown, grotesque, and wild, Access denied; and overhead up grew Insuperable heights of loftiest shade, Cedar, and pine, and fir, and branching palm."
}

But do you know William Gilpin's "Forest Scenery?" 'T is a rare old book, and one for the forest. I well recollect the time I first read it. It was in a woods which bespoke great age, beneath the gnarled, wide-spreading beech that I spoke of, upon the trunk of which had been carved the initials, and the dates inscribed, one I 864 , and another 1869 , very rough and irregular now, almost like the seams and cracks of the old tree itself, yet still discernible from those days of long ago. I could scarcely have found a more fitting 
environment in which to peruse and think over the quaint, and sometimes delightfully interesting, "picturesque remarks" of the old Nature lover. There were keepers of the forest, it seems, whose offices included that of ranger and bow-bearer (come down to them), and underkeepers, in smaller dwellings. "The underkeeper feeds the deer in winter-browses them in summer-knows where to find a fat buck-executes the King's warrants for venison-presents offences in the forest-courts-and prevents the destruction of game." Another of his duties was "to drive the forest" and mark the cattle. Who would not have been one? But Gilpin's picture of a certain Mr. Henry Hastings, one of the keepers of New Forest, and his lodge (' $t$ is almost a den, like the lair of a wild beast), is especially attractive, surcharged, as it is, with the very atmosphere of the ancient, historic wood, savory of game, and redolent of many things archaic, and antique, and forest-like :

"Mr. Hastings was low of stature, but strong and active; of a ruddy complexion, with flaxen hair. $H$ is cloaths were always of green cloth. His house was of the old fashion; in the midst of a large park, well stocked with deer, rabbits, and fish-ponds. He had a bowling-green in it; and used to play with round sand-bowls. Here, too, he had a banqueting-room built, like a stand, in a large tree. He kept all sorts of hounds, that ran buck, fox, hare, otter, and badger; and had hawks of all kinds, both long, and short winged. His great hall was commonly strewed with marrow-bones; and full of hawkperches, hounds, spaniels, and terriers. The upper end was hung with fox-skins of this, and the last year's killing. Here, and there a pole-cat was intermixed; and hunter's poles in great 
abundance. The parlour was a large room, completely furnished in the same style. On a broad hearth, paved with brick, lay some of the choicest terriers, hounds, and spaniels. One or two of the great chairs, had litters of cats in them, which were not to be disturbed. Of these three or four always attended him at dinner; and a little white wand lay by his trencher, to defend it, if they were too troublesome. In the windows, which were very large, lay his arrows, cross-bows, and other accoutrements. The corners of the room were filled with his best hunting, and hawking poles. His oister-table stood at the lowered end of the room, which was in constant use twice a day, all the year rourd; for he never failed to eat oysters both at dinner and supper, with which the neighboring town of Pool supplied him. At the upper end of the room stood a small table with a double desk; one side of which held a Church Bible; the other, the book of martyrs. On different tables in the room lay hawk's-hoods; tells; old hats, with their crowns thrust in, full of pheasant eggs; tables; dice; cards; and store of tobacco-pipes. At one end of this room was a door, which opened into a closet, where stood bottles of strong beer, and wine; which never came out but in single glasses, which was the rule of the house; for he never exceeded himself, nor permitted others to exceed. Answering to this closet, was a door into an old chapel; which had long been disused for devotion; but in the pulpit, as the safest place, was always to be found a cold chine of beef, a venison-pasty, a gammon of bacon, or a . great apple-pye, with thick crust, well-baked. His table cost him not much, tho it was good to eat at. His sports supplied all but beef and mutton; except on fridays, when he had the best of fish. He never wanted a London pudding; and he always sang it in with, ' $M y$ part lies therein-a.' He drank a glass or two of wine at meals; put syrup of gilly-flowers into his sack; and always had a tun-glass of small-beer standing by him, which he often stirred about with rosemary. He lived 
to be an hundred; and never lost his eye-sight, nor used spectacles. He got on horseback without help; and rode to the death of the stag, till he was past fourscore."

That, gentlemen, certainly smacks of the chase! And, with the type set in the old-time f-shaped s's, as in the first edition, the effect of this passage is greatly increased. What a singular character he was; a sportsman, Epicurean to the core, and yet temperate, and observing the laws of the Church, even though he did keep "a great apple-pye" in the pulpit; and how he loved and enjoyed the things of the wild! I think I should have liked to know him.

Thoreau's "Walden; or, Life in the Woods"-one must not pass that by, nor "The Maine Woods," nor the many other chance descriptions of the forest from the pen of that strange, wild lover of the woods. Nor should we forget some of the pages in Whitman's "Specimen Days;" nor the forest poems of Longfellow, Emerson, and Bryant; nor the forest scenes in the "Scarlet Letter;" nor, in England, the work of Scott, Ruskin, Richard Jefferies, and Mr. George Meredith. Wilson Flagg has written an interesting account of the intensity of his boyhood impressions upon first entering a virgin forest, how he watched the scenes as he rode through them- "the immense pillars that rose out of a lerel plain, strewed with brown foliage, and interspersed with a few branches and straggling vines; the dark summits of the white pines that rose above the round heads of the other species which were the prevailing timber; the twilight that pervaded the woods even at high noon; and I thought of their seemingly boundless extent, of their mysterious solitude, and their 
unspeakable beauty." I am reminded, too, of "The Marshes of Glynn," the

" Gloom of the live-oaks, beautiful-braided and woven With intricate shades of the vines that myriad-cloven Clamber the forks of the multiform boughs,"

-ah, Lanier was a poet! Nor must I neglect to mention Dr. W. C. Gray's forest musings, nor Mr. John Muir's vivid inspirations on the trees of the Western Sierras, nor the chapter on "The Hills," in "The Forest," by Mr. Stewart Edward White. And the time would fail me to tell as I ought of the travels of Parkman, and the explorations of Stanley in the Congo, and of the "Silva" of Evelyn, and Michaux, and the monumental work of Sargent.

I have enjoyed these forest descriptions in literature. There are many more such passages, of our day and before it; I have presented but a few of them. Some of the earliest are among the best. Vergil writes in his imagination, you remember, of how the spears of Polydorus grew into trees which shed blood upon being broken. Dante also, in his great vision, saw that the twigs ran blood, and were alive. And so is the forest indeed, in its way, full of beautiful life and joy, which rebuke us at their wanton destruction.

I leave the old woods with awe and reverence. It has served its purpose. Most of the best trees have been felled, and the oldest of those remaining have staghorns of dead branches at their tops-the minarets, as it were, of a place of worship. The young growth is thick, however, and in time a new forest will spring up in its place, and will no doubt fill the same useful- 
ness. But the old woods, the woods of the Indian and early settler, has nearly all of it gone its way with the pioneer and trapper and the former life of years ago, the rugged life of the hunter and rail-splitter in the days of solid homespun clothes. New conditions have confronted us, and we must meet them. The trees have ripened, and it is for our interest and that of others that they should fulfill their intended usefulness as lumber before decay renders the wood unfit. Some of the old oaks, as I have said, were over three hundred years of age. It was time they went. They have helped us by their beauty and shade, and it is not a profanation to have them go, but they fall rather in the fullness of their maturity, as veritable patriarchs of the forest.

And then, too, the view that we have, now that part of it has been cut away, is so restful and beautiful that we think that perhaps, after all, it is really better that the woods has partly been lumbered off. We can see from the old homestead the lovely hills across the Miami. It is like a pastoral. We could not see them before; indeed, we hardly knew they were there. In winter these hills present white fields bordered with brush, seen througn the old trees' penciled tops; in spring these same sloping ridges become again fresh in their green and purple and furrowed brown; in summer we can see the golden harvest and the reapers; in autumn the many-colored hues of the fall of the leaf heautify and once more vary the color of the landscape and the strips of woodland:-winter, and the snowy covering. 
As we stand again near the path leading into it, with the woods in its full panoply of green, and the wild melody of the wood thrush sounding, toward the twilight, at the entrance to this minster of the beautiful old forest, with the crosses and antlered spires above it piercing the sunset sky, and with its dingles beckoning back to us so that we can not leave it, we feel ourselves influenced anew, and spiritually uplifted, by the strange, mystic druidism of the trees.

There recur to memory the opening lines of Bryant's familiar ode. We, too, say that

"The groves were God's first temples."

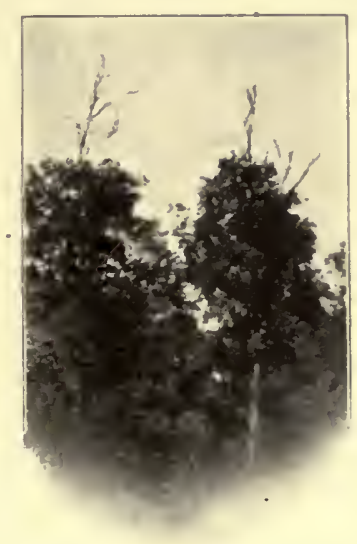

STAGHORNS. 


\title{
SQUIRRELS AND SQUIRREL HUNTING.
}

\author{
"We can not but pity the boy who has never fired a gun; he is no \\ more humane, whlle his education has been sadly neglected."
}

-Thoreau.

"I have entered many woods just for the purpose of creeping through the brake and the thickets. Destruction in itself was not the motive: it was an overpowering instinct for woods and fields. Yet woods and fields lose half their interest without a gun-I like the power to shoot, even though I may not use it."

-Richard Jefferies.

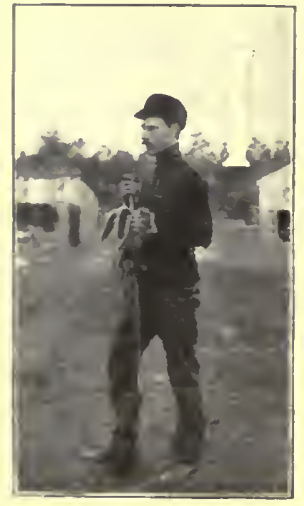

THE SQUIRREL HUNTER.

"Gayly chattering to the clattering

Of the brown nuts downward pattering,

Leap the squirrels, red and gray."

-Whittier.

HAVE always been attracted to squirrels with an uncontrollable impulse. I must be on the hunt, away to the woods and to their haunts. Squirrel hunting was the favorite pastime of Rip Van Winkle. Why should it not be ours also?

The best kind of a day in which to hunt squirrels is on a still morning, quite early, when there has been a rain on the day before, and the woods are yet a little wet, and the leaves perhaps not through their dripping; or on a late afternoon, when the wind has died down and they are out for their supper among the branches. Any quiet dawn or evening will do, but after a rain is the most favorable time, for they will be out then in full force, if the trees are not too wet for them. In the middle of the day they 


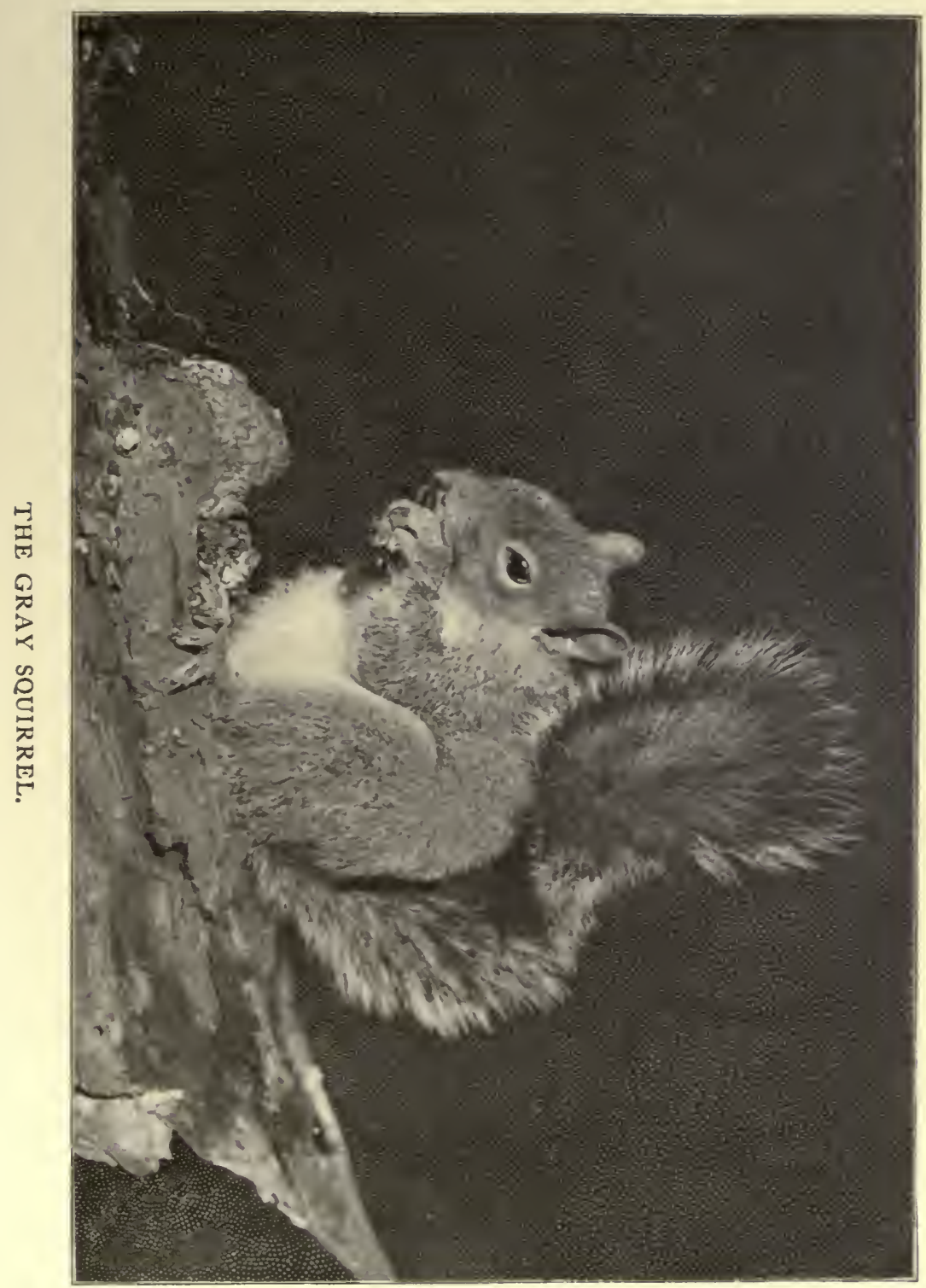

13 

are either in their holes, or lying stretched out on some limb sunning themselves, where you will not perceive them. On windy days they scarcely come out at all on the trees, but will stay on the ground, and you will not be so likely to see them unobserved.

The right season of the year is, of course, the autumn, and for several reasons. In the first place, they are then at work among the nuts, and so their whereabouts can easily be detected by the shucks pattering and dropping through the leaves to the earth; in the second place, they are then past the breeding season, and it is more humane to hunt them; in the third place, their flesh is very delicious in the fall, juicy, and tasting of the nuts which they have eaten; and in the fourth place, their skins will not shed the hair after the summer is past, and so can be kept and enjoyed, if you wish to tan or dry them. I have heard of robes made of squirrel skins, and they must have been very warm and comfortable; a real feeling of woods life must come upon one when beneath the squirrel fur.

Spring, however, is a good time to get the young ones. Young squirrels in springtime are so innocent and so approachable. Having never been hunted, they are very tame. They have not yet learned the difference between good and evil. Their flesh is very sweet and tender then, and almost melts in your mouth. Nothing, however, could be better than a well-broiled squirrel which has been killed on a hickory on a frosty morning in the autumn. I have hunted them at all seasons of the year, before the present restrictive game laws were in force, and I well recollect one winter shooting one from the very top of a bare, leafless 
maple, where it looked like a piece of bark caught and swinging in the air.

Some men seem not to know how to keep still when in the woods, and not to know what noise is. I have taken friends out to hunt, and they have splashed through the woods like hippopotamuses, and then were always wondering where the squirrels were. Squirrels, however, can walk among the driest of dry leaves without making the noise of scarcely a patter. I have seen them creep along logs or on the ground among a thick fall of leaves, where it seemed to me impossible that they could go so noiselessly, and yet at but ten paces distant I have not been able to detect a scratch or a rustle. It is not always that they are silent, for I have seen them running and rustling and leaping and playing among the fallen leaves as if with a real, genuine joy at the woods' wildness; and I have seen them in a game of tag circle round and round the trunk of a shagbark until the woods was dinned with the rattle of the strips of bark and with their chucklings. Sometimes-though rarely-squirrels will mistake a man's swish among the leaves for the jump and crash of one of their own species, and I have had them make directly toward me at such times, when I had made a sudden misstep or had stumbled. As a rule they do not seem to scrutinize the woods very carefully in search of an enemy, but to depend more upon their sense of hearing; for I have walked quietly round and round a tree in wet weather, in order to get a good shot, and they seemed totally oblivious of my presence. But let me once tread on a twig and snap it, or let me rustle and crackle the leares injudiciously in dry 
weather, and-plunge! down comes the nut, andsplash! there he goes like a twinkling into the beechsplash! over into the oak, there to twirl around chuckling down into his hole for the rest of the day. The little fellows always chuckle in the greatest glee when they thus escape you and find refuge in their hollow limbs, snickering away at you from their safe old strongholds with the most taunting derision and selfassurance.

I have seen them make their summer nests. Once I was especially fortunate. I had gone to the woods to sleep beneath the trees; and, upon awaking, as I was lying upon the moss and gazing at the leaves above me, I was suddenly further aroused by the splash of a large gray squirrel in the branches - then another-and another, from various directions, until five had come to the rendezvous. They were in a walnut-tree of moderate size, just across the brook from my resting place, and I could see them very distinctly. They would bite off leafy sprays from the outstretching boughs, and then run up the tree, and each would fasten his own sprig and twist it in some way with the other twigs of the nest. It did not take them very long, for they worked quite hard at it, and in less than an hour they had made quite a comfortable home, apparently, for they left off work, and three of them leaped away and sought other employment. The two remaining may have been a pair, and this may have been their housewarming, or a barn-raising on the part of their neighbors. They soon went up into their leafy cocoon, and did not come out again while I was there. Thoreau used to climb the trees and look into their hiding places, 
to see what their nests were made of, and how they curled themselves up in them.

Wilson Flagg rightly placed the squirrel among the picturesque animals in a scene; for, surely, with the exception of an antlered stag, a large gray or fox squirrel is the most picturesque feature to be found in any woods, so graceful is he, so alert, so associated with all wildness and with nutting-time. I like to be with them, and to observe them in their arboreal habits. Watch a sleek gray squirrel when the hickory nuts first ripen, as he twines around among the thick foliage in search of a nut, finally to pluck one off, and then to run back to a favorite crotch or branch, and curl his tail over him and begin work. The green hulls fall in bits all around you, and soon also pieces of the inside shells, as he digs in with his long teeth after the rich kernel; or perhaps the whole nut may slip from his grasp, and fall through the leaves with a loud plunge to the ground. He has many such losses, however, and accepts them philosophically, as not to be too deeply inquired into. He is "content with the quia," as Dante advised the human race to be; and forthwith, after a little pause of bewilderment, runs out to another twig and finds another nut. There does not seem to be much method in the way squirrels pick the nuts, running up and down at random, everywhere and anywhere, as they do; but they generally manage to strip the tree.

The squirrel is the symbol of autumn. The way to tell a squirrel's presence in the fall is simply to wait for the patter and splash of the nutshells falling among the leaves. You will frequently be aided also in determining their local habitation by the new scratches 
of their paws upon the bark of the trees or along the top rails of the fences. Listen! Yes, he is surely there, and eagerly at work, and he will not notice you unless you make too much noise; for a squirrel likes his meals as much as we do. But shake a sapling, and he will go to the other side of the tree, where John can have a crack at him. I have seen as many as five in a single tree, all of them seated on different limbs, with their tails over their heads, and nuts in their paws, nibbling away for dear life. I have heard of as many as twenty being seen in a single tree, in the autumn, making havoc among the nuts; but I rather suspect the multiplication table was used in that story, or the magnifying glass, or some other agency that increased the number. It is a common adventure, this, however, in autumn, to find several at work in one well-stocked hickory or beech-and then what a pattering there is of the shucks, the ground being covered with the gnawed bits. If these dropped pieces beneath the trees are fresh, then you may know the squirrels have not left their feeding ground, and you can bide your time for them presently to appear. But, if they are browned over and evidently a few days old, it is likely the squirrels have either been killed or have sought new and better mast. They will not always desert their tree, if the nuts are plentiful, even though they know you are below, and hear you; but they will perhaps simply scamper up to the top and there conceal themselves for a time, perhaps reaching for another nut and eating it there amid the branchlets, the numerous leaves themselves being indeed an empalement for them, so that you will scarcely discern them except by the tossing or 
shaking of the foliage. Frequently I have been misled by the sudden lurching or swaying of boughs by the wind into believing that a squirrel was among them, but I never like to risk a shot until I am sure of it.

Gray squirrels do not have a pouch on each side of their jaws, like the little ground squirrels; but I have often seen them come down a tree with their cheeks so distended and puffed out that it seemed as if they must have something in them, part of a nut, perhaps, tucked away on each side, making thern appear curiously deformed. But their deformity will vanish when they reach their holes or trysting places. Often one will carry a large walnut, hull and all, in his mouth to a neighboring tree, or to some fence post, or a top rail, or a stump, or a prominent rock, or some other favorite place, before beginning operations; and there he will sit and eat. Shells can frequently be seen in spots remote from trees, the nut having been carried thither by some squirrel. I have often seen them bury nuts, as I crouched among the saplings; and I could not bring myself to shoot them at such times, but would watch them closely, and would soon become more interested in their habits than I was in my gun. Sometimes it would seem as if a whole family were at it (which is, indeed, very likely the case), each one making a little dive into the leaves, then putting the nut in, and covering it or not as the whim seized him. And yet nearly every one of these hiding places is known, and, if their furry lives are spared, will be found again with remarkably unerring precision in winter through a foot of snow. I have scen holes in the snow where the squirrels have dug at once to their store of nuts, but I am inclined to think 
that they may search about beneath the snow sometimes before they find what they are after; though, so far as my own observation goes, they seem to know the approximate location, and do not have to go very far when they have once delved beneath the white covering. By what instinct of location that is done it is probable that neither you nor I can ever completely know, though their sense of smell undoubtedly helps them. Perhaps, however, if we were squirrels, we should recognize the little hummocks and hollows of a few rods square as familiarly as we do the slopes and ridges of our fields. The accurate and intimate knowledge of the topography of their diminutive tract, which life for some months or years among the trees has given them, may be the real explanation of their apparently mysterious intuitions.

Squirrels evidently select certain spots as their feeding grounds. I have seen the projecting ends of old logs, or the knot of a fallen limb jutting out from amongst the leaves, completely surrounded by a pile of walnut hulls, cast aside by the squirrel as he gnawed into the kernels. They are beautiful little animals, and it is interesting to see them seated in the crotch of a tree or on a fence rail, munching away at a nut for dear life, and sending the pieces of hull and shell scattering in every direction. Sometimes, if disturbedno doubt, as he thinks, rudely-a squirrel will not give up his half-gnawed nut, but will carry it with him between his teeth to a safer vantage point, and there finish his meal. I can hear their light pattering among the leaves, as they pick their way along the ground and jump from place to place; though sometimes, if a 
squirrel is suddenly scared, one will make as much noise as a dog or a large animal, in his leaps down the hillside. They can, if necessary, however, as I have said, be very wary, and can slide along among the dry fallen leaves with scarcely a sound to betray them.

The word squirrel means, from its Greek derivation, shadow-tailed; that is, the squirrel is enabled to use its tail for a shadow, which was a conception characteristic of the poetic mind of the Greeks. Thoreau, however, was not quite satisfied with that, and made the following whimsical suggestion: "Squirr, 'to throw with a jerk,' seems to have quite as much to do with the name as the Greek 'skia,' 'oura,' shadow and tail." Yet the philologists are right, and the historic derivation will have to stand, no matter how well the little animal may happen to fulfill in its motions the meaning of this other dialect word that is spelt so much like its rightful name.

I do not believe that squirrels see distinctly, unless their attention is drawn to an object through fear or some other cause. Then they rivet their gaze on it with something of a ferret-like intensity of look in their little black eyes, to crawl toward it, perhaps, by short leaps along a branch, or by coming down gradually on the trunk, or perhaps, and more likely, to scamper away with a little "chuck! chuck!" I remember one morning sitting at the bottom of a hickory, after setting a twitch-up, and being nearly startled out of my skin by suddenly hearing stealthy scratchings on the bark just at my side. Keeping as motionles and still as death, I hesitatingly and slowly turned my eyeballs sideways, and there, within two feet of me, on the tree trunk, 
was the largest and most beautiful wild gray squirrel that I have ever seen. My elbows were resting on my knees and my hands clasped between them, and by turning my left forearm around on its elbow I could have stroked him. He seemed, and doubtless was, wholly unconscious of my presence, thinking me an old, mosscovered stump, perhaps, and, after a moment's pause, leaped quietly to a little maple sapling a few feet away, and then down among the leaves and off toward the brook. I suppose he never knew how near he came to making friends with a boy that day. On three other times also have squirrels been within my reach. I would have felt like a murderer if I had shot them then, or at least had not given them a good chance for their lives.

The most provoking experience, however, that I ever had was on a similar occasion, one fine, brisk morning when I had been out to a woods on a squirrel hunt and had been lucky enough to get one big gray fellow. I had him hanging from my suspenders, as all boys do, by the thongs of his hind legs, piercing between the ligaments and the bone with my knife, close to the joint, and then inserting a slender but stout stick, or twig, some few inches long and with a crotch at one end, and supporting that stick at each end by the button flaps of one side of my suspenders, letting the squirrel hang and flop against me as I walked-prouder than any king, and feeling as if I had sprouted fringes of buckskin along the seams of my corduroys, and were wearing beaded moccasins. It began to get far past the sunrise and I turned toward home, giving up any further luck for the day, and, seeing a large hawk in 
the crotch of a tree, I thoughtlessly shot all the cartridges remaining in my magazine at the bird, which still stayed perched there. But further up the ridge, as I was eating my breakfast, lo! a big gray squirrel came out on a branch directly above me not six feet away. Now if there was one thing I detested it was to go home with only one squirrel; I always wanted at least two, and to see three squirrel tails hanging and swinging together seemed something like success and roused my pride. Yet I had no cartridges, not even one, and he was going away! I did not want to see him go, so, with great recklessness, I threw away all that I possessed and could collect at him,- - potatoes, stones, sticks, walnuts, - but all without avail, for, after jumping to a young hickory sapling at once and protecting himself for a time amid its twigs, he finally leaped to the ground and scampered up an oak. On another occasion, after a long hunt, and only one squirrel to show for it, as it was late in the morning and the squirrels seemed to have all gone on a journey, I whiled away a few moments before cooking breakfast by shooting the few cartridges I had left at a white splinter on a tree, with such gratifying success as to assuage a little my solitary squirrel. I evidently could have hit another, I argued, could I only have seen him. At another time we "cornered" a fine big fox squirrel in the crotch of a walnut, some forty feet from the ground, on the slope of a steep ridge, and as we were shooting at the spot trying to drive him out, what should he do but go out, and actually run up to the end of the limb, and deliberately leap off into mid-air, and, apparently by flattening and stretching himself 
out as much as possible, like a flying squirrel, soar gradually to the bottom of the ravine and skip up an oak into his hole. It was the bravest thing I have ever seen done in the woods, for the leap was at least fifty feet; and the little fellow was evidently a bit afraid of it, for he hesitated an instant before taking it. But things were getting too warm for him, and so off he went. He certainly was the General Putnam among the squirrels, and should have been in the charge at Balaklava. I hope he still lives (but doubt it), or at least that he was not hurt by his long aeronautic expedition.

I remember once being out with my dog. I had arisen before daybreak, and had tramped through the dewy grass and weeds far into the woods after squirrels. It was a clear, beautiful morning. It had rained the day before, and I hoped thus to step noiselessly and stealthily up to within a few feet of them. Cobwebs and mosquitoes were thick and annoying, but a large bunch of pennyroyal was a check for the latter, and the hunting passion was too strong upon me to mind the cobwebs, which I merely brushed aside with the barrel of my rifle. I had not intended to have the dog go, for he would sometimes race among the leaves and scare the squirrels, and so I had driven him back. I always liked to "still hunt" best for squirrels, anyway. Suddenly, however, when pretty well in the woods, listening for the earliest barking chuckle or the first splash in the branches, I was startled by the very slightest movement in the path behind me; and, turning, there was my dog. He had followed me, even after my refusal, bound to come. He looked up into 
my face with the most beseeching appeal, and I could not resist such language as that. So he stayed, and was even more quiet than I was, following in my steps like an Indian. But there! the gray had heard us. Three big leaps! In the last he sprang from the hickory toward a large branch of a maple, some thirty feet away, but missed his judgment, and passed beyond to the trunk, to which he clung, and disappeared around on the other side in safety in a twinkling. I have killed squirrels on the run, and that with a rifle, but I do not care ordinarily to risk the shot with a single ball, and so I let him go. The dog leaped and barked and became perfectly wild with desire, so strong is the dog's instinct for hunting and wild life. He took a run, with a short, passionate bark, and leaped up on the tree trunk nearly ten feet, dug into the bark with his nails, and strained every fiber to reach the squirrel, who long ago was safe away in his hole and chuckling. But it was a vain struggle; he was made to be a runner, not a climber. In justice to the dog, however, it should be said that in the end we did not return home emptyhanded, and that he had his full share of the spoils.

I used sometimes also to divide with the cat, and he certainly did enjoy my hospitality. More than milk, more than scraps of any description, did that old Maltese like to eat squirrels-even the fur,-crunching it down as if he recognized their relationship to the mouse, and so, in a sort of penance, in lieu of the little mice, made greater havoc by proxy. But he got so that he would follow me to the woods, and yowl and skip and scratch about among the leares, and so I desisted, and remanded him to the milder effects of his previous diet of bread and milk. 
How the squirrels twine in wild grace among the limbs, frisking their tails and chuckling, or perhaps giving a sudden start and bursting out into a regular landslide of barks and all sorts of queer, drawling innuendoes and exultations! One will sometimes hug a branch and become almost a part of it, so that at a distance he will not look much bigger than a knot, although at the right view the branch can be seen to swell out a little where the squirrel is. One will, if hard pressed, after taking refuge, put out his head comically on one side of the limb, and there take his bearings. I remember one fellow's hiding from me in the crotch of a tree. He was totally concealed, and would have remained safe, except that in congratulating himself at his escape he would every now and then quirk up his tail with a little .jerk, and it would wag and wave in an indubitable revelation of his whereabouts. Like the ostrich, he failed to realize he had other than his head to hide. Sometimes one will lie for hours stretched on the top of a limb of his size, the only indication of his presence being his tail hanging and swaying with each breath of wind.

Mulberries are a very substantial part of the squirrels' food in summer, but I have not seen them eat the wild black cherries in the autumn, though deer will browse upon the cherry sprays and pick up the fallen fruit with the greatest relish. I have killed squirrels also while munching the seeds of the black gum-tree and winding among its masses of berries. But in our Northern country their main dependence is the various nuts, and they apparently enjoy the buckeyes as well, some buckeye-trees being a regular rendezvous for 
them. Which kind of nut do they like best? I do not know. They apparently have no preference, but attack all indiscriminately and with equal ferocity; and yet I have noticed that the hickories are the first to go.

I like to hear the squirrels bark. It is a sound of wild Nature. The bark, or call, of the gray or fox squirrel is a curious intermixture of squeals, and snickerings, and chucklings, as if he were congratulating himself on some extra good fortune. How one will suddenly spring round the trunk of a tree, and give vent to his feelings in a rollicking challenge of these chuckles, following one after another as fast as possible-and then a long, drawn-out squeal-then another series of rapidly issuing chuckles-and then another long squeal! Or perhaps he will run up the tree a little, barking as he goes; or, breaking off, will scamper quickly to a crotch, and finish his bark there; or perchance will make two or three stops before he is through with his statement. It is one of the sounds to listen for in the mornings; for he is always inclined to open the day with this joking announcement of his presence on the arena, and he usually closes the twilight with this same queer drollery of the woods.

Squirrel hunting in my boyhood was the most enjoyable thing we ever did. We entered into it with a real zest for the woods. We watched the sunsets according to the Scriptures, and, if the morrow looked favorable and the wind was dying, we would arrange for a hunt. Each would take a separate ridge as his special game preserve, but we had a way of signaling to one another with the Bob W'hite! of the quail, thinking the squirrels would not notice that familiar 
whistle; one call and its answer merely getting our bearings, two calls repeated from one of us meaning danger over in the other direction (when perchance one perceived a squirrel which his fellow on the next slope might not see), and three Bob Whites! in succession being a summons to get together, for a squirrel was in limbo and we must concentrate forces.

I used to like to listen to the hum of insects in the woods while waiting for the squirrels. The hunting was not all of it. I liked to think of the older days, the days of midnight country serenades, of the old-time and real negro minstrels, of Colt's revolvers, and of "The Arkansaw Traveler." And my boyish dreams were no mere fanciful or passing visions, but were, in their way, the symbols of convictions about life. ' $T$ is a priceless heritage, the love for the country, and, once neglected and lost, it can not soon be recovered.

So, during my hunts, I have not only shot squirrels at all seasons of the year, among the buds of springtime, amidst the mulberries in the summer, up in the hickories in the autumn, and even on the icy boughs of winter, but also have killed them with more than one kind of firearm-with a .22 Flobert-Remington, with a .44 Henry, with a .56 Spencer, and with muzzle and breech loading shotguns, both single and double barreled-and have tried my hand with the old cap and ball rifle, and have gone out breathing forth slaughter with the more primitive weapons of slings and stones. I have shot them while seated in crotches scattering their nutshells below; and on the sides of the shagbarks or maples, while they listened 
intently for suspicious noises; or up among the tossing sprays, as they leaped from one bough to another; and, again, on the ground, as they played among the fallen leaves or perched on the stumps and logs. But the crowning triumph of all was one day when with the big .44 I shot one while on the run at full speed along the outspread limb of a beech, some fifty yards away. I have since killed them with shotguns while running, but never again have I got one on the "wing," so to speak, with a rifle. For the boy to learn first to shoot with a rifle is better than to begin with a shotgun. Any one can hit a squirrel with a shotgun, but it requires considerable accuracy of aim and steadiness of nerve to bring one down from the top of a hickory with but a single bullet, and there is more satisfaction in getting him then, and more real sportsmanship in the hunting. It gives a squirrel at least some chance for his life to hunt him with a rifle. Target practice of some kind is essential to keep up one's accuracy of aim, and some of the old beeches in the woods are marked and well stocked with lead from my Henry, where I practiced; and I never found that it hindered my hunting with a shotgun to have attained some skill beforehand, where it was necessary, in the use of the rifle. I used to consider it, and it was, one of the greatest pleasures I could have to bring a squirrel down with one shot from my Henry from the top of a tall shagbark or a beech, to see him fall and to hear him splash through the branches, and then finally come with a plunge and a thud to the ground at my feet. That was a real achievement:

Sometimes a wounded squirrel will manage to crawl 
away beneath the leaves or into some hollow log, before you can reach him when he has fallen, or perhaps may scratch a three-legged way back up to his tree again; and there he will die, in a lingering agony, alone in his beautiful coat of hair, upon the matted and bloody leaves.

Have you ever had the "buck fever" when in the woods? Every deer hunter knows what that is. I have at times been taken with it when squirrel hunting, and my rifle would sway most unsteadily as I aimed, while my arms were trembling in the excitement like those of a man with ague, and beads of perspiration stood on my brow. One does not frequently hit the mark when in such a condition; he either pulls the trigger too soon or too late, or in some way misses. Men do not have it ordinarily in mere target practice, but the presence of real, live game at the end of the sights curiously affects a man.

To hear the crack of a rifle in the woods always stirs my blood. The boom of a shotgun does not have the same music to it, nor does it signify so much; for the rifle speaks to us of the deer, and of a wilder life than shooting on the meadows. I could always tell the sharp report of my Henry from among the many other sounds of the guns, if I heard it from a distance when the boys had borrowed it for the day. I loved the sound of it. Indeed, a man's trusty rifle is almost as much a favorite and as good a friend as his faithful dog. Leatherstocking, you remember, carved his "marks" upon his, and notched the stock whenever he killed a deer. So, I have sometimes seen names and emblematic devices cut upon the wood, perhaps while 
the owner was resting on a $\log$, and I imagine, if I had followed Leatherstocking and notched my Henry for every squirrel, it would now be checkered like a pistol grip.

I once bagged a squirrel with only half a tail. It is very possible that I myself had been the cause of his loss, for I did not hit all the squirrels I shot at, and might merely have cut through his brush. It had undoubtedly been shot off, but the little fellow was at last to be brought low, even after that escape-like many a soldier who, after numerous battles, finally falls, shot in the head. I recollect also killing two squirrels whose stomachs were simply bursting with dry, chewed nuts. Whether there had been a lack of water for them, and so their food had become too dry to digest, or why they were so distended, I do not know, unless they had almost been starving, and had suddenly come across a tree full of fruit and had gorged themselves to the utmost.

The boys could take a whole day for squirrel hunting in pioneer times, and never go out of the woods. They had a certain plan, by which they would simply saunter along from one wood lot through another until they reached the bluffs of the river, there eat their lunch, and then spend the afternoon on the stroll home again, with perhaps a dozen squirrels to show for their trip.

I have heard some fairly good yarns about squirrels. One old man, I remember, who was nothing loath to see the eyes of his nephews distend almost to bursting at his tales, related to me one time a long, rather rambling story of a celebrated hunt in which 
he and some fellow Nimrods took part, in the days when squirrels were as thick as flies, and deer as thick as squirrels are now, sir. They took the old muzzleloader and went out for the day, when work was slack, to see which one could kill the most squirrels, in a kind of contest. No rabbits were to be taken under any consideration. Now it chanced that the lot fell to him to begin the contest; and he went at it leisurely, he said, picking off one or two occasionally as he came to them, and shooting them each one, as the rule was, in the head, a miss of any sort (it was understood) at once forfeiting the old cap and ball to the next in line. The victims began to pile up by the dozen with his unerring aim, and finally by scores, until he had at last shot sixty-two, and all in the head. Just at that moment a squirrel was seen at a short distance and he leveled and took aim, but, the sunlight or some other objectionable object striking his eye at the time, he pulled trigger just a bit too soon, to see the squirrel fall, of course, but-alas, this time, shot in the neck! Disgraceful! And so he was barred out, and the gun passed to the next competitor. How long the contest lasted, or how many he might have killed, if he had only hit that last one in the head, or how many squirrels they actually brought home, deponent sayeth not, although there was doubtless some foundation to the story. I think he once said that the number might have been forty-two, instead of sixty-two, that he got; he could n't exactly remember, it was such a common occurrence in those days.

In Franklin County, Ohio, whose population at present is nearly one hundred thousand and whose 
county seat is Columbus, there is the tradition of a squirrel hunt in the fall of I 822 which surely eclipses all previous or subsequent records. The squirrels having become quite numerous and threatening the farmers' crops, and therefore a pest, a bounty was offered for every scalp of a squirrel brought in; with the result that a general "hunting caucus" was called for in all the various townships and a mighty hunt planned to last for several days, the astonishing total of nineteen thonsand six hundred and sixty scalps being the outcome of the slaughter; nor was this really all, for many of the hunters did not put in an appearance at the close, and consequently made no returns. I think, after this, there need be no further questioning as to the truthfulness of the phenomenal hunting stories of the early settlers.

It is a fact, however, that in pioneer times squirrels-and big gray ones, too-were killed by the hundred where now only one is seen. It was an every-day thing in grandfather's day to go cut with no other weapon but a club, and no trouble at all to bring in a few rabbits or squirrels with it for breakfast. There are traditions hereabouts of an old farm hand, in the halcyon days when the woods were well filled with game, who could throw a stone from his hand with about as unerring and fatal an aim as any fair shot with a rifle. He never even took a sling, not to speak of a gun, but would, like David, pick a few smooth stones out of the brook, and stroll beneath the hickories armed cap-a-pie; and he never failed to bring back enough squirrels for supper. He could hit three crows out of every five in the top of a big oak. And what is more, these facts are pretty generally authenticated 
by the corroborations of all who knew him. Such a wild strain as that is not found nowadays. It is rare, and truly native, and smacks a little of the old primeval forest life and of genuine woodcraft. He was like the hero in Bulwer's "A Strange Story," who would even climb the trees and capture the squirrels among the branches.

One can frequently detect the presence of squirrels by the scent in the woods. Rowland E. Robinson speaks of that in his "New England Fields and Woods," and tells how, with the other odors in spring, you are made aware "by an undescribed, generally unrecognized, pungency in the air that a gray squirrel lives in your neighborhood." It is true, however, of the other seasons as well as of spring, for there is always a peculiarly woodsy and wild, animal-like smell in the haunts of squirrels. One can get a hint, when a faint whiff reaches him, of the many things that dogs know which we have but rarely even suggested to us.

Squirrels make very beautiful and winsome pets. In parks they sometimes become so used to people that they lose their fear, and will take peanuts and other morsels from their hands. They can be tamed, and have become loving and trusting companions of men, as human as dogs even, and very cleanly, and much less destructive than puppies. They will, however, sometimes bite those whom they do not know. The late W. J. Stillman once wrote a very touching account of his delight in some squirrels, Billy and Hans, that he had as pets, and of the remorse that he felt, after his intimacy with these captives, that he had ever killed 
or hunted any in the woods. Such reflections, however, come later in life, and are not apt to suggest themselves to the boy in the woods with a gun on his shoulder. But, surely, these few sentences from his paper will commend themselves to every lover of the squirrels : 1

"I feel so keenly their winsome grace when I can watch them in freedom that I can not draw the line between them and myself, except that they are worthier of life than I am. The evolutionists tell us that we are descended from some common ancestor of the monkey. It may be so; and if, as has been conjectured by one scientist, that was the lemur, which is the link between the monkey and the squirrel, I should rot object; but I hope that we branched out at the Sciurus, for I would willingly be the far-off cousin of my little pets."'

There are many varieties of squirrels in this country. The old woods boasts at least three, the gray, the fox, and the little striped ground squirrels, and there were formerly many flying squirrels. The com-

1 "Billy and Hans," by W. J. St:ilman. "Century Magaz:ne," February, 1897; page 623 .

2In a more recent paper, entitled "Squirrel Land" (" Century Magazine," August, 1905,) Mr. Stillman gives it as his opinion that it is the sense of smell which is the real secret of the mystery of the squirrel's gathering of the hidden nuts among the leaves. "They evidently smell them in the ground, for I myself have buried them at the depth the squirrels use, and they were always dug up at once." Stillman also refutes the charge that squirrels are depredators of bird's nests or destroyers of trees, and says that the only animal food that he has ever known his pet ones to take was a taste of bacon, which he offered them. Surely Stillman had a genuine, sympathetic understanding of the squirrels. Had he but been more familiar with our own gray squirrel of the American forests, instead of the European species, it is possible that we might have had some stil] more attractive studies of squirrel life from his pen. 
mon red squirrel of the East is not found here, and I am glad of it; for they and the grays do not often agree, and the red fellows drive their big gray brothers out, and I like the gray squirrels better. The red squirrel snickers and chirrups, whence doubtless his name, the chickaree; the gray squirrel barks and chuckles, and I like him for it. The red squirrel is a ubiquitous scold, and ought to be gagged or put on , the ducking stool. I have sometimes killed big fox squirrels whose fur had almost a tinge of black, thus suggesting that possibly they were a cross between a fox and the black variety of the gray, but I have never seen a genuine black squirrel in the woods, though they are found at times farther up in the State. The Southern fox squirrels have, however, frequently a darker coat than our more rusty fellows, and it is possible that one of them may have strayed up North.

The ground squirrel, or chipmunk (its Indian name), is a curious little fellow. He gives a sharp chirp, something like a cricket's, but more intense, whence one of his names, the hackce. He is valueless for food, being so little, though his flesh is not bad to the taste. I have had him sit perched at one end of a $\log$ while I was seated at the other, and so long as I was motionless he would observe me with apparent indifference, but just as soon as I made the slightest motion his sharp squeak would strike my ear, and whisk! away he would flit under the log. This was the first kind of squirrel that I ever saw, when but a little child, and I can well remember the thrill that went through my being when I realized that I had actually seen a real wild creature of the forest playing 
about the roots of an elm. Lowell, in "An Indian Summer Reverie," thus very correctly describes the little ground squirrel's capering:

" The chipmunk, on the shingly shagbark's bough, Now saws, now lists with downward eye and ear, Then drops his nut, and, cheeping, with a bound Whisks to his winding fastness underground."

It is commonly supposed that the chipmunk lives almost wholly upon the ground, but I have seen him crawl up into some pretty tall beeches, and there eat the nuts, though of course as a rule his habits are of the earth, earthy. It was Robert Louis Stevenson, I beliere, who first suggested that the gray squirrel was an idealist, always living in the upper air and climbing the trees to the heights.

The flying squirrel is another curious little creature, with its large dark eyes and singular parachute habit of soaring away from one tree to another, half animal, half bird. It is the bat among the squirrels. Every one knows of Thoreau's experience in capturing and bringing home a flying squirrel in his pocket, and then, from pity, the next day taking it back to the stump where he had caught it, and letting it loose again.

Squirrels will apparently migrate in feeding time from one woods to another; for, all of a sudden, in a grove which has been tenantless there will some day be heard the cheerful barking of the squirrels in numbers on the boughs. They swim, too, and years ago, when squirrels were more plentiful, a great drove of them crossed the Miami, and the boys got on the opposite side of the river and gathered in with clubs as many as they wanted for their respective dining tables. 
I do not know to what extent squirrels are $1 \mathrm{n}$ sectivorous, and yet I have seen the old ones clamber slowly along on the dead top branches of a tree and gnaw frequently at the bark. I know that they eat the bark of live maples in the spring, but why should they nibble at this dead wood? Could they be sharpening or cleaning their teeth? It was on a maple that I saw them in this instance, however, early in spring, before breeding time, and it may be that they had just come from tasting the fresh sap of the lower limbs and were now, simply from curiosity, testing the leafless upper ones. However, it is well known that they eat many birds' eggs and the suspended chrysalids of certain butterflies.

It is not so often that squirrels have been written of at length in literature or with any great appreciation, nor so frequently as one would think, notwithstanding the great mass of natural history books upon them. I have often wondered that Thoreau was n't fascinated by squirrels more than he seems to have been. He liked them, and they frisked about the ridgepole of his house, and I have just spoken of the flying squirrel that he captured. But scarcely any one that I have read seems to do full justice to the beautiful, graceful, wild gray squirrel of our hardwood forests. Mr. Burroughs has written pleasantly about them, and in one of his papers he quotes from a Western correspondent who was quite enthusiastic over them. Wilson Flagg certainly appreciated them, and I have already made mention of Stillman's sensitive and tender tribute. Mr. Charles D. Lanier has also written 
very beautifully of the squirrels; Mr. Ernest Ingersoll has shown himself a true lover of them, and has made them a delightful study; Mr. John Muir has told some interesting facts about the Western Douglas squirrel in his book on "The Mountains of California;" there is a good imitation of the gray squirrel's bark in Mrs. Olive Thorne Miller's "Little Brothers of the Air;" and do you remember the squirrels which delighted Mr. Jenkin Lloyd Jones when, with his Jess, he rested in the park of a small Western town?

In a recent novel, too, Mr. Irving Bacheller's "Eben Holden," old Uncle Eben trees a squirrel with the help of his dog, and then brings him "down out of the tree by hurling stones at him" - a method which some others of us have tried, but have not always been able to make successful. There is also a quaint story by Uncle Eben of Squirreltown and Frog Harbor; and the wild man of the woods used to trap squirrels for his food. One of Frank Stockton's stories is "The Squirrel Inn."

In England Edward Jesse has written of the squirrel with much appreciation in his "Scenes and Occupations of Country Life" and "Gleanings in Natural History." Richard Jefferies also speaks of the squirrel more than once in his novels, as in "After London" and "Wood-Magic," and has this passage in his essay on "Marlborough Forest:"

"High over head in the beech-tree the squirrel peeps down from behind a bough-his long, bushy tail curved up over his back, and his bright eyes full of mischievous cunning."

But perhaps it will pay us to turn from these modern writers on the squirrel and see what has been 
said by the older naturalists and lovers of the woods. Part of the instruction for fly-making, as given by Izaak Walton, included the fur from a squirrel's tail. I have happened, too, upon some quaint observations on squirrels in two old and long-forgotten writers of the sixteenth century, and, besides being curious and unmodern in style and point of view, they really show quite a correct knowledge of our little furry brothers. Linschoten, a traveler, says of the gray squirrels in India that, besides being destructive, they "have a taile like the penner of an ink-horne, and grayish speckled haire: they are pretie beasts to keep and to passe the time withall." And old Topsell, quite an observer for his day, speaking of their nests, says:

"In summer time they gather together abundance of fruits and nuttes for winter, even so much as their little dray [old word for nest] will holde and containe, which they carrie in their mouthes, and they lodge manie times two together, a male and a female (as I suppose). They sleep a great part of the winter like the Alpine mouse, and very soundly, for I have seen when no noise of hunters could wake them with their cries, beating their nests on the outside, and shooting boltes and arrowes through it, until it were pulled asunder, wherein many times they are found before they be awaked. They growe exceeding tame and familiar to men if they be accustomed and taken when they are young, for they runne up to mens shoulders, and they will oftentimes sit upon their handes, creep into their pockets for nuttes, goe out of doores, and returne home againe; but if they be taken alive, being olde, when once they get loose, they will never return home againe. They are very harmefull, and will eat all manner of woolen garments, and if it were not for that discommodity, 
they were sweete-sportful-beastes, and are very pleasant playfellows in a house."

William Gilpin, the hermit of New Forest, in his "Picturesque Remarks on Forest Scenery," has written of the squirrel, but his book was published before the forests were much cut off in England. Gilpin was not like Flagg, for, singularly, in his account of the animals that inhabited the forest, he did not think the squirrel of great picturesque importance among them; yet is his description of one well worth reading:

"In the same class [hares and rabbits] we rank the squirrel. He is not of consequence to be numbered among the picturesque ornaments of a scene: but his form, and manners; his activity, and feats of dexterity, are very amusing. On extraordinary occasions, when he is agitated by love, or anger, his muscles acquire tenfold elasticity. He descends a tree in a rapid spiral, as quick as thought-darts up another in an opposite direction-flings himself from tree to tree with amazing exactness-and pursues his mate, or his rival, among the mazy branches of an oak, with a velocity that eludes the sight."

I myself have seen them quarrel, in these later days, one driving another away from a nut-tree.

Nor has the squirrel been overlooked by the poets iny more than by the naturalists. It is but to be expected that poets should like the squirrels, and I think they do them better justice. To old Shakespeare let us go! For, if squirrels act not according to his word, there is no health in them. And, sure enough, we find that the squirrel had not escaped the notice of Shakespeare, but is associated, like an elf, with all forest 
witchery. Mercutio, in "Romeo and Juliet," says of Queen Mab that

- Her chariot is an empty hazel-nut,

Made by the joiner squirrel or old grub,

Time out of mind the fairies' coachmakers :'

and in "A Midsummer Night's Dream" Titania says to Bottom, in the wood,

"I have a venturous fairy that shall seek

The squirrel's hoard, and fetch thee thence new nuts.'

William Browne, too, an old poet of the earlier seventeenth century, has left, in his "Brittania's Pastorals," such a really modern and realistic picture of a squirrel hunt that I give it here entire. It is the best, and only poetic, description of a squirrel hunt that I know of in literature:

"As a nimble squirrel from the wood, Ranging the hedges for his filbert-food, Sits pertly on a bough his brown nuts cracking, And from the shell the sweet white kernel taking, Till with their crooks and bags a sort of boys, To share with him, come with so great a noise That he is forced to leave a nut nigh broke, And for his life leap to a neighbor oak, Thence to a beech, thence to a row of ashes ; Whilst through the quagmires and red water plashes The boys run dabbling thorough thick and thin, One tears his hose, another breaks his shin, This, torn and tatter'd, hath with much ado Got by the briars; and that hath lost his shoe : This drops his bands; and that headlong falls for haste;

Another cries behind for being last :

With sticks and stones, and many a sounding hollow, The little fool with no small sport they follow, Whilst he from tree to tree, from spray to spray, Gets to the wood, and hides him in his dray." 
Surely he was a fine poet who wrote that. And he loved Nature otherwise equally as intimately. He was the John Burroughs of the seventeenth century.

Cowper writes of the squirrel in an interesting way in "The Winter Walk at Noon," in "The Task:"

"Drawn from his refuge in some lonely elm, That age or injury has hollow'd deep,

Where, on his bed of wool and matted leaves,

He has outslept the winter, ventures forth

To frisk awhile, and bask in the warm sun,

The squirrel, flippant, pert, and full of play :

He sees me, and at once, swift as a bird,

Ascends the neighb'ring beech; there whisks his brush,

And perks his ears, and stamps, and cries aloud,

With all the prettiness of feign'd alarm,

And anger insufficiently fierce."

There are many other references to the squirrel in poetry. I shall give a few of those that have come across my notice. Mrs. Browning has this passage, in "The Lost Bower:"

"For you hearken on your right hand,

How the birds do leap and call

In the greenwood, out of sight and

Out of reach and fear of all;

And the squirrels crack the filberts through their cheerful madrigal."

Corentry Patmore also, in "The Angel in the House," has noted the squirrel's love of solitude:

" Upon the spray the squirrel swung,

And careless songsters, six or seven,

Sang lofty songs the leaves among,

Fit for their only listener, Heaven."

'The present poet laureate, too, Mr. Alfred Austin, in "It the Gate of the Convent," has the squirrel seeking the forest cover:

"The russet squirrel frisked and leapt

From breadth of sheen to breadth of shade." 
Shelley says, in "Alastor," that his solitary poet dwelt in the wild so long that the doves and squirrels would partake of his food and the antelope stay her steps in admiration. Would it be possible nowadays for many of us so to cultivate the friendships of the forest? Must we always think of it as merely a poetic fancy? It is said of William Hamilton Gibson that he had such an influence over the wild inhabitants of the woods, was so en rapport with their life, and had so won their confidence and trust, that, if he would but hollow his hands and hold them up with a cooing whistle toward a branch, the birds would nestle in their cup, and the squirrels would come down the great tree trunks and let him stroke them as they gazed wonderingly at him. And how beautifully he has written of the secrets of the squirrels and all the life of the woods, and with what perfect art in illustration has he sympathetically drawn their homes and faces.

In our American poetry, besides my preliminary quotation from Whittier, I recall a few allusions to the squirrel in some of Bryant's poems. He says, in his apostrophe "Among the Trees," that the kings of the earth are not arrayed as are the forest-trees in autumn,

\footnotetext{
"While, swaying on the sudden breeze, ye fling Your nuts to earth, and the brisk squirrel comes To gather them, and barks with childish glee, And scampers with them to his hollow oak."
}

He says that "the squirrel in the forest seeks his hollow tree" in time of storm; that, while the birds are singing in the tree-tops,

The squirrel, with raised paws and form erect, Chirps merrily." 
Bryant also is correct in having the squirrel about in winter, as in the following, from "A Winter Piece:"

"From his hollow tree

The squirrel was abroad, gathering the nuts Just fallen, that asked the winter cold and sway Of winter blast, to shake them from their hold."

Longfellow speaks of the squirrel frequently, but especially in this familiar passage:

" U $\mathrm{U}_{\mathrm{p}}$ the oak-tree, close beside him, Sprang the squirrel, Adjidaumo, In and out among the branches, Coughed and chattered from the oak-tree, Laughed. and said between his laughing, 'Do not shoot me, Hiawatha!' "'

In our recent verse I have met with nothing better than these lines from a short poem entitled "When Chestnuts Fall," by Mr. Joel Benton:

"The squirrel now, half-ambushed, sees

His longed-for largess in the trees;

A keen frost chills each breeze that blows,-

The squirrel starts, alert with joy ;

An allied frenzy stirs the boy;

Marauders born they both agree

To burglarize each bounteous tree ;

And to their separate comrades call,

When, urged by frost, the chesnuts fall."

I have not shot a squirrel for several years, and I do not know that I ever shall do so again, though the hunting instinct is very strong, and one does not know what he will do when it suddenly comes upon him with a whiff of autumn. But I shall not soon forget my feelings at my last hunt. Bang! —splash!-thud! I ran quickly over to the spot. There he lay, down 
among the nuts and leaves that he had loved so well, with a few bright spots of his life-blood on them. Poor little beauty! He had thought me his best friend, perhaps, and I had turned out to be his worst, his fatal, foe. As he twitched his last death spasm, the poor little fellow turned his liquid eyes upon me with tearful, unutterable, most pitiful remonstrance. Yes, I had killed him; I had destroyed his life-life that was once so happy and graceful and beautiful among the leafy branches, but now to be swaying, leaping, and chasing, and playing tag among them no more forever. The look of sad reproach in the eyes of a dying squirrel, the death look, as he languishes and quivers in pain, is enough to fill the stoutest heart with the deepest remorse. No eyes among the wild creatures, to my notion, of those I have seen, are so wondrously beautiful as those of the doe and the squirrel, and none are so frank in their expressions. What beautiful creatures the gray squirrels are! Their eyes, their sleek coat of fur, their sensitive ears and alert body, full of life, teeming and pulsating with living blood-all animals are like them, all constant wonders, perpetual miracles! I do not know that we ought to kill them.

Yet hunting is one of the most humanizing, if not the most so, of all pursuits that a man can do in the open air. Most of the hunters whom I have known have had natures brimful of the milk of human kindness toward all the animals. Old William Cobbett, who was a good friend of the four-footed, argued very strongly in favor of the ethics of hunting, and believed thoroughly in its value. Why, we kill, by proxy, thou- 
sands of cattle daily for the food of the human race; and sheep and oxen, after all, as Thoreau said, "are but larger squirrels." The majority of wild animals that are killed by man die more or less instantaneousiy; and it is true at least of some of them that they would otherwise have a lingering, painfu! death from starvation, or sickness, or old age, alone, deserted, or maltreated by even their own families.

I can not refrain from closing this paper with two selections on hunting from Thoreau and Dr. W. C. Gray. Thoreau thought that his having witnessed the killing of a moose up in Maine, the destruction of one of "God's own horses," had lowered him, and expresses his regret in these beautiful and inspiring words:

"I already, and for weeks afterward, felt my nature the coarser for this part of my woodland experience, and was reminded that our life should be lived as tenderly and daintily as one would pluck a flower. . . . Nature looked siernly upon me on account of the murder of the moose."

Dr. Gray likewise, though in his time more of a hunter, had at last his final hunt, when, stricken by remorse, he gave up the practice. He had just shot a deer, but had not hit it fatally, and tells the concluding story thus (and may it be ours also) :

"He was helplessly wounded, not killed. As I advanced upon him, he fixed his large, lustrous, frightened eyes upon me, and I ended his life with another shot. There he lay in all his purity and beauty. I was smitten to the heart with remorse. I considered that he had lived the pure and innocent 
life of Nature, had never harmed any one or anything, and there he lay, the victim of an invader and murderer.

"This ended my hunting, a favorite sport of more than half a century, and which had the double attraction that it led me deep into the solitudes of Nature, with their unfading freshness and unfailing charms."

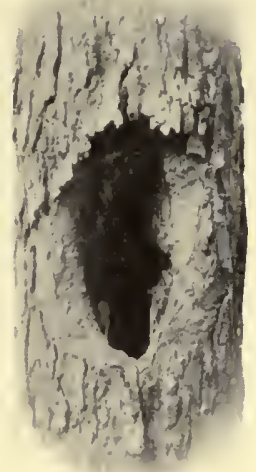

A SQUIRREL'S HOME. 


\title{
SOME THOUGHTS ABOUT MY DOG.
}

\author{
I.
}

"I humbly thank Divine Providence for having invented dogs, and I regard that man with wondering pity who can lead a dogless life."

-Philip Gilbert Hamerton.

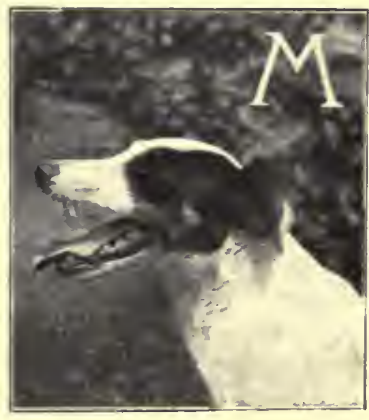

MAN'S BEST FRIEND.

EN like dogs, and always have liked them, from the time when Ulysses returned from his long voyage and was recognized by his old dog Argos. Dogs are generally so open, frank, and sincere in their natures and actions, and so receptive and eager to learn, and so intelligent, that men find them the best of companions by the fireside or in the woods. They are naturally cleanly, too, and can be taught to be a great deal more decent than thousands upon thousands of men are, and they like to be so. A well-bred dog is very much of a gentleman; and he quite consistently selects a true man as his highest ideal, and is always content when in his presence.

How beautiful is the head of a dog! How liquid and winsome the eyes, and how wonderingly they look up into ours! 'The dog is man's most faithful friend. He has become much nearer to man in his life than has any other animal. He eats to a great extent the same food: often lives under the same roof; learns to 
understand more of our words than any other animal; and frequently shows his intelligence and appreciation in ways that reveal unmistakably real affection and character. He has more of humanity to him than any other animal. He protects us and watches over us at night; saves us when in danger; cries and whines with us in sympathy when in pain; and plays with us in mad joy when we condescend to notice and to laugh with him. Yes, the dog is a little man!

The dog has found an enduring place in our literature in the poetry of Shakespeare and Scott and Mrs. Browning, and in the beautiful and well-known story, and the most exquisite bit of pathos in all English literature, too, "Rab and His Friends," by Dr. John Brown. There have been a number of books written about the dog. Edward Jesse's "Anecdotes of Dogs" is a very interesting compilation bearing on the intelligence and affection of these animals. There lately also appeared an anthology entitled "Praise of the Dog," by Ethel E. Bicknell. More recently, his heroism and prowess have again been celebrated in "Bob, Son of Battle," by Mr. Alfred Ollivant, "The Call of the Wild," by Mr. Jack London, and "The Bar Sinister," by Mr. Richard Harding Davis. There are two other books worth mentioning-_Diomed: The Life, Travels, and Adventures of a Dog," by Mr. J. S. Wise, and Mrs. Sarah Knowles Bolton's volume upon "Our Devoted Friend the Dog." Of the many magazine articles relating to the dog $\mathrm{I}$ recollect especially $\mathrm{Mr}$. John Muir's account of his adventures among the glaciers with Stickeen, and Mark Twain's protest against the prevalent vivisection entitled "A Dog's Tale." 
Mr. Henry van Dyke, too, has written a good story of a dog called "A Friend of Justice," in "The Ruling Passion." When his master first patted him on the head, runs the tale, "the dog looked up in the man's face as if he had found his God." His master put a cross over his grave. "Being French," said he, "I suppose he was a Catholic. But I'll swear he was a Christian."

Shakespeare speaks of the baying of the dog as in itself music; and who that has ever heard it can forget the deep, bell-like, echoing tones of a hound in the distance as he scents his game in a chase among the hills? We find the dog remembered in many of the finest paintings and hunting pictures, in numberless photographs, and in occasional dog statuary. Indeed, there can be few more inspiring subjects for an artist who loves animals than a well-formed, healthy dog in a graceful, eager poise.

In the chase or in the library the dog will always be close to man's heart.

II.

\author{
"Tears are in my eyes to feel \\ Thou art made so straitly." \\ -Elizabeth Barrett Brozuning: "To Flush, my Dog."
}

LORD BACON said that man was the god of the dog; and if it be not true, it ought to be true. For no dependent creature so well deserves man's good intentions and care, or should have so fine an example set before him, as the dog.

We make companions of dogs; we enjoy their being with us and our being with them. And yet we 
do not know all of their life; we can not enter the source of their thoughts or impulses any more than we can penetrate to the inner personality of a fellowman, and see with his eyes, and think with his mind. I suppose that there will always be a certain sphere of existence wherein every being lives absolutely alone, unrevealed, save by outward tokens, in the citadel of his own soul. This I believe to be true of dogs and horses and the other animals. We know something of them, but it is not a great deal, and perhaps they know as much of us as we do of them. It was Dr. McCosh, I believe, who, when asked whether a dog, in baying at the moon, actually conceived of the moon as a separate mass of matter in the skies, or merely perceived its shining face coming up across the great dome and barked at it in a sort of superstition, replied, with his characteristic Scotch humor, "I do not know; I have never been a dog."

We can not, we do not, know all that passes in a dog's mind, his memories, his thoughts, if he has any, or whether he lives only in the present, after all. That they have dreams, we know. I have seen my little dog lying in deep, snoring sleep, when suddenly he would begin wagging his tail up and down against the floor, or would paw with his forefeet as if digging; and, when awakened, he would look about him in a dazed way in the most amazed fashion-just like a human being, with the memory of a dream. And I remember once, out at a farm where the dog's chief master and companion had been away for a time, when I by chance put on his master's old canvas coat one morning, the dog, when he first saw me, bounded toward me with a 
look of recognition and with eyes bright, only to calm down considerably when he found who it was wearing the coat. He had always liked me, but it was the old coat which he had recognized, and I believe it had brought back to him somehow the memory of his master whom he had loved so well. Many instances similar to this have come to my notice of the memory of dogs. I have had a dog friend recognize me at once after a long absence of months. I have seen a dog pine and howl in dismal grief at the memory of a dead master. Dogs are very human, after all. Could they but tell us-well, they could tell much! I have had dogs come to me, and endeavor with the most singular gulps and queer little sounds of the throat to tell me (as I supposed) some tale of their own, which I did not know. They can, and do, indicate many things to us very readily by their actions, but their physical make-up is such that they can not tell us all they might. We can only judge them imperfectly by human analogy, and so do not know the whole truth about them. They have, too, a range of life which is all their own, and which we do not experience. If we but had the keen scent of the dog, the quick hearing of the deer, and the eyesight of the eagle, what would we not enjoy in our walks through the woods and meadows!

A man was watching my dog one day, and commenting upon his intelligence. "Well, sir," said he, "they 're good companions, I tell you. I 've never yet seen one that was n't." And I could heartily agree with him that, for the right man, there is no better friend than a dog, nor one more appreciative of man's 
kindness. The possibility of real companionship with a dog is well illustrated in Philip Gilbert Hamerton's account of his etching voyage, entitled "The Unknown River," on which Tom, the dog, had "the satisfaction of dining with his master on terms of something like equality." The sharing of his meals with his dog has from time immemorial been the sworn motto of every true sportsman. Nay, furthermore, so says Mr. Jenkin Lloyd Jones, in his "Jess," "'Love me, love my dog,' is the chivalrous demand of man upon his brother man." It was the pathetic lament of Rip Van Winkle, when he returned to his native hamlet after his long sleep in the Catskills, "My very dog has forgotten me!"

I like to watch a dog dig after a rabbit, or a wood mouse, or other "such small deer," as Shakespeare calls them. How he will tear roots and every obstacle away in his frenzy to get at his quarry! When he first has cornered his game in his den he will put his nose carefully in and take a good sniff; then a little vigorous digging; and then another sniff; then still more vigorous digging; and then he pulls the earth away with his paws, gets down close to the ground, and takes a good long smell of the imprisoned game. Yes, he certainly is there! And then he goes at it with perfect fury, scattering dirt, stones, leaves, sticks, and the whole of the obstructing matter to the wild winds. Perhaps he may have to be called away by his master; but if he can only get his rabbit or mouse, what a proud dog he will be, and how his eyes will brighten and his tail wag as he brings it and lays it at his master's feet!

Many a battle royal do dogs have with snakes, shaking them and dragging them in triumph, like the 
body of Hector, in the dust. I know of one old shepherd who could, so runs tradition, snap the head off from a snake by a single shake. But dogs are very wary, and always see to it that they catch the snake by the tail. One of a dog's chief delights in the country is to dig out the moles in the garden. There is nothing, however, a dog likes so much as to get after a cat. Both seem to enjoy the sport. The dog, with all his tremendous onslaught, will only approach within just a certain distance, when he will lie down and paw at her with one forepaw, or eye her intently and wag his tail vigorously and bark. When, all of a sudden, spit and spit fire, and she arches her back and growls and snarls, and up he is like a flash, scared but eager for the fray; and so they will often keep it up for half a day. Yet I have seen cats and dogs thoroughly fond of one another, the cat even lying down and sleeping against a dog, and resting her head down in among his thick, glossy coat of hair. Assuredly, they had cast aside the law of tooth and ravine.

Dogs apparently calculate and judge just about as we do in similar circumstances. They reach conclusions pretty rapidly sometimes, just where and when to jump or pounce after a rat or a mole or a rabbit, and, so far as their life goes, it seems to me that it is precisely like our life.

III.

"There is but one drawback to a dog's friendship. It does not last long enough."

-Henry van Dyke.

Not long since I owned a very intelligent fox terrier, by name McChesney. He was a little four-footed friend whom I lored, and who loved me. We took 
walks together in the woods and the sweet grass, and he romped and leaped in health and joy and friendship. But one morning a few springs ago he darted away from the housc for a few moments, never to be seen again by me since then. How long it was before I regained spirits at the loss of the beautiful little fellow I do not know; but I shall never forget him, for I have found few men like him. All that is left of Mac now is an old newspaper advertisement for him, two scratches on the hardwood floor, his collar, and a loving and inspiring memory. I have wondered whether I am never to see this best and most loyal of earthly friends again. Shall we not look into each other's eyes once more?

Some of the happiest experiences in my life have been in the woods with him. He would always dart away ahead of me deep into the woods, only to peep suddenly above some little knoll to see if I were still coming; or, if he caught the scent of a rabbit and rushed away with a little yelp, it was not long before he would be dashing past me again, as I walked on, or, if I sat on a $\log$ for a short rest, would come to me with wagging tail and look up to me with a gulp of friendliness.

Little Mac has become to me a symbol-a symbol of fidelity, trust, loyalty, love, and the innate beauty and purity of life. Often has he lain in my lap and looked up at me with wagging tail, or has sat there and looked straight into my eyes, and when I would lean my head on my hand often has he laid his little black-and-tan head next to mine, on my hand, in mute affection. Yes! my little four-footed friend, I have 
learned more from you and your glossy coat of hair than from many men, more of what life is and should be; and, if there is to be any heaven for righteousness of disposition, or any reward hereafter for faith and forgiveness and loyalty to a master, then I certainly hope to see you again-somewhere, surely, in dogHeaven, wherever that may be!

I believe in the immortality of animals, not only because they deserve immortality and live the same life that we do, and because there is nothing whatever in the Bible against it, but its whole spirit, in all that it has to say of animals, is decidedly for it, but also because, if these beautiful forms of life that have been our friends and neighbors on earth live not again, existence itself is an anomaly. Their loss, if they perish forever at death, is an irreparable, a perpetual loss, and their love and friendship are all the more terrible in their pathetic cruelty of fate and chance. Why should the loss of such friends be forever? Is it in vain that beauty has been created in such forms? Can it be that the eyes of a dog who lores us now shall look no more into ours, but be turned forever into dust? If so, then is grief absolutely inexplicable, and life utterly blank and hopeless for all living creatures. For the lower animals are supported by the same lifeprinciple that we have, and share the same earth that we enjoy, and, so far as they go, their mental processes seem to be precisely like ours. Unless it be so that all the creation shall finally be resolved into annihilation and no living creature live after death, I can never give up my hope in the immortality of our dumb animal friends. But that is a word of despair, and no lover 
of life should be without at least a lingering hope in its perpetuation, which should grow into a practical certainty the more he sees and knows of all that is included in our word Nature.

Do you mean to tell me that, because it says that we are of more value than sheep and sparrows, Christianity therefore says that I shall never see my dog again, and that all the unspeakable beauty and tenderness and infinity and mystery of Nature are a mere phantasm and a delusion? Well, I say that the New Testament gives us no such message, but that it comes with a great hope to all lovers of God's beautiful creation. The untold suffering of all earthly organisms is not to be without compensation, but there shall be a new heaven and a new earth! I, for one, rejoice that the Indian buries with him his bows and arrows, and lies down to dream of the Happy Hunting Grounds, and

"Thinks, admitted to that equal sky,

His faithful dog shall bear hım company."

No, my dog's loss is no new thing under the sun. There has simply come to him and me what is the common experience of all the world-grief. It has occasioned no great surprise, for it is the general lot of man, nor has it caused any revolution in Nature as if at the unlooked-for presence of some terrible and heartless destroyer. Nature remains the same, and when I go to the woods the beautiful green trees are as inspiring as ever, the thrushes sing as exquisitely, and the gray squirrels stir the old hunter in me just as powerfully. But I miss something in my walks now. No more does a little black nose sniff among the leaves 
and roots, and push itself under my hand, in his doggish ways. No more do I hear his answering little bark when I whistle.

Mac did n't amount to a great deal in practical usefulness, although he did what he could even in that line. He never learned to hunt (though how he loved the woods!), but he was a good watch-dog, and as fatal a mouse catcher as the best trap. No, I can never play the traitor to Mac, and say that he had his blemishes, and that perhaps another dog would take his place better. It is true, he did have his little stubbornnesses; but he really never meant harm to his fellow dogs (except for self-protection, when he showed the pluck of a bulldog) or to any living thing, and he won his way through life by the most winsome and loving ways, and we were all the better for his little presence. I have seldom seen in man or beast an instance of truer, sincerer appreciation of kindnesses and evident gratitude for them. And so I loved him with my whole heart.

Mac was my first dog. I taught him all his dozen tricks; and how he did enjoy and relish their performance! He and I understood one another perfectly. I can not possibly forget him. It is painful to know grief, even for a dog; and I can never think of him without a pang. But his-even with the pain-will always be a pleasant memory. I can only hope that he has fallen into good hands.

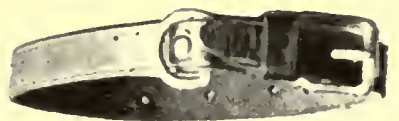

MAC'S COLLAR. 



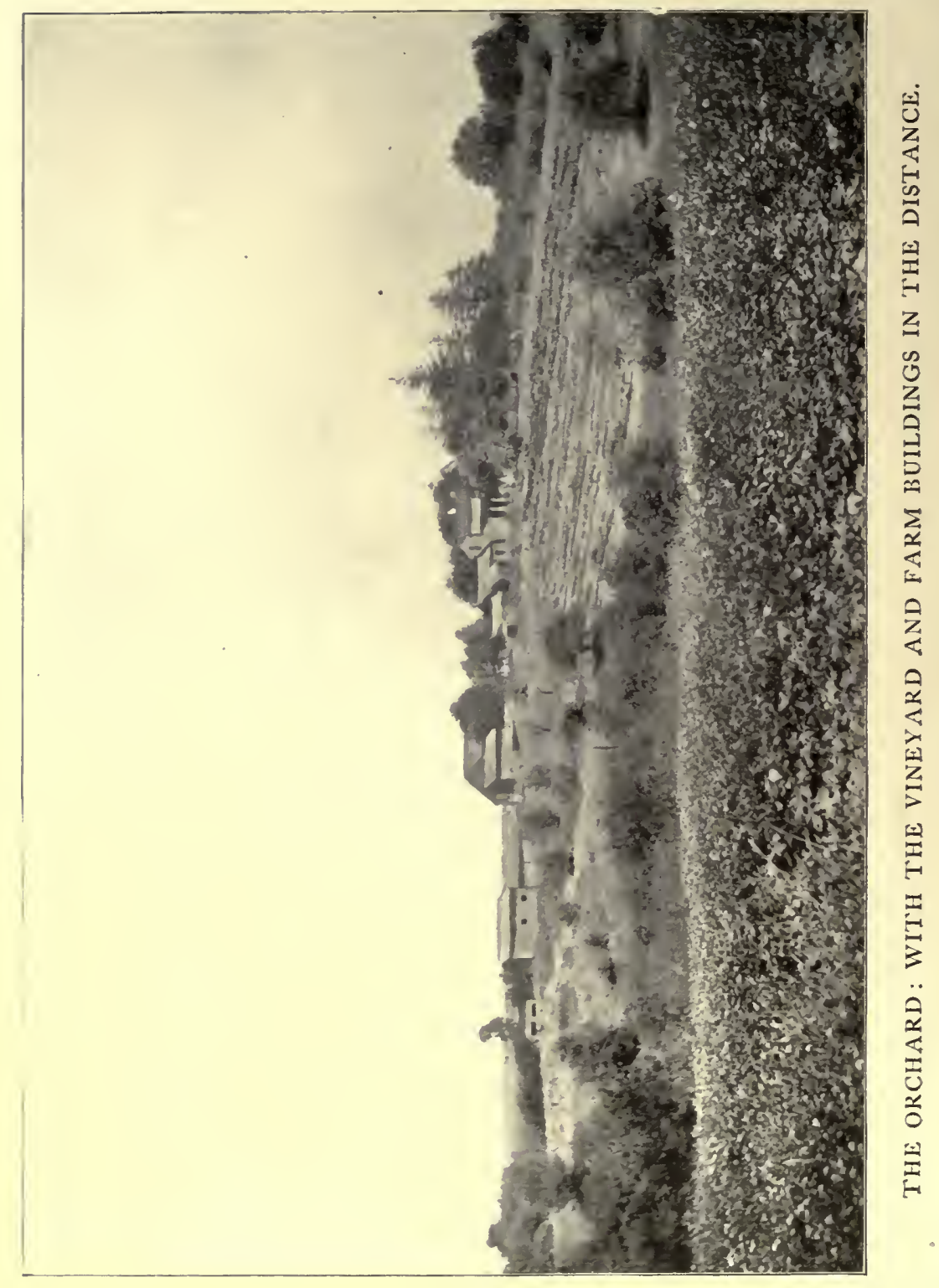




\section{THE ORCHARD.}

"* The apple-boughs entwine

And make a network fine,

Through which the morning vapours pass,

That rise from off the dewy grass.

"And when the spring-warmth shoots

Along the apple roots.

The gnarled old boughs grow full of buds

That gleam and leaf in multitudes.

"And then, first cold and white,

Soon flushing with delight,

The blossom-heads come out and blow,

And mimic sunset-tinted snow."

-Edmund Gosse.

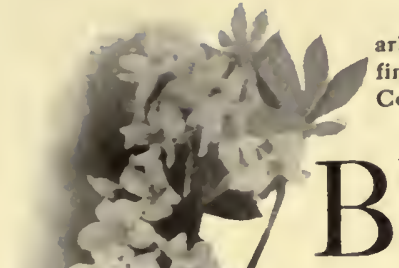

"Nay, you shall see my orchard, where, in an arbor, we will eat a last year's pippin of my own graffing, with a dish of caraways and so forth;-come, Cousin Silence."

-2 Henry IV.

the orchard we generally mean an apple orchard, and one toward decay; for somehow, with their great extending limbs, flaked with straggling bark and mottled with lichens, the oldtime apple-trees are the most poetic. They were planted years ago by our forefathers, and have the picturesque look of age. A newer orchard may be neater, and means perAPPLE BLossoms. haps more money, but it takes one of the old-time orchards, with its immense boughs and tall masses of branches and sprays, rich and luscious with old-time apples, to arouse sentiment.

The old-time varieties, too, were the best, and can not always now be reduplicated-the big yellow Bell- 
flower, the speckled Fall Pippin, the striped Northern Spy, the crimson Smith's Cider, the red Baldwin, the deeper-colored Canada Red, the Rhode Island Greening (for even "Little Rhody" gave a name to a famous apple); and so with all the other kinds-the Rambo, Astrachan, Seek-no-farther, Winesap, Ben Davis, Rome Beauty-each has its own distinctive markings and its own unique taste among its rivals.

There are sweet apples, like the large greenishyellow, sheep-nosed Bough Apple, or the Pumpkin Sweet; there are sour apples, like the Maiden's Blush and Summer Queen; there are those that are half-andhalf, like the delicious Tulpehocken; and there are the acrid Siberian Crabs. Some come to maturity early in summer, like the little Strawberry Apple, some in time of harvest, like the Harvest Apple and the Cathead; but most ripen in the fall, though a few hang on even to the winter, and are best fitted to be eaten in the following spring. The autumn, however, is the typical season for apples. Then is the time for the picking of the fruit, or the shaking of the boughs for those that are to be used for cider. It is well, if you want to select and improve your apples, to have a preliminary thinning out of the inferior ones first (Nature will help you by some windfalls), leaving the largest and best fellows to grow into still more tempting dimensions (which they will do) by appropriating the strength of the tree thereafter for themselves alone. They must be handled carefully, so as not to be bruised; a sack slung about the shoulders is better than a basket. Ah, I am up in the trees again among them. The bough is fairly exhausted, bending almost to breaking, with 


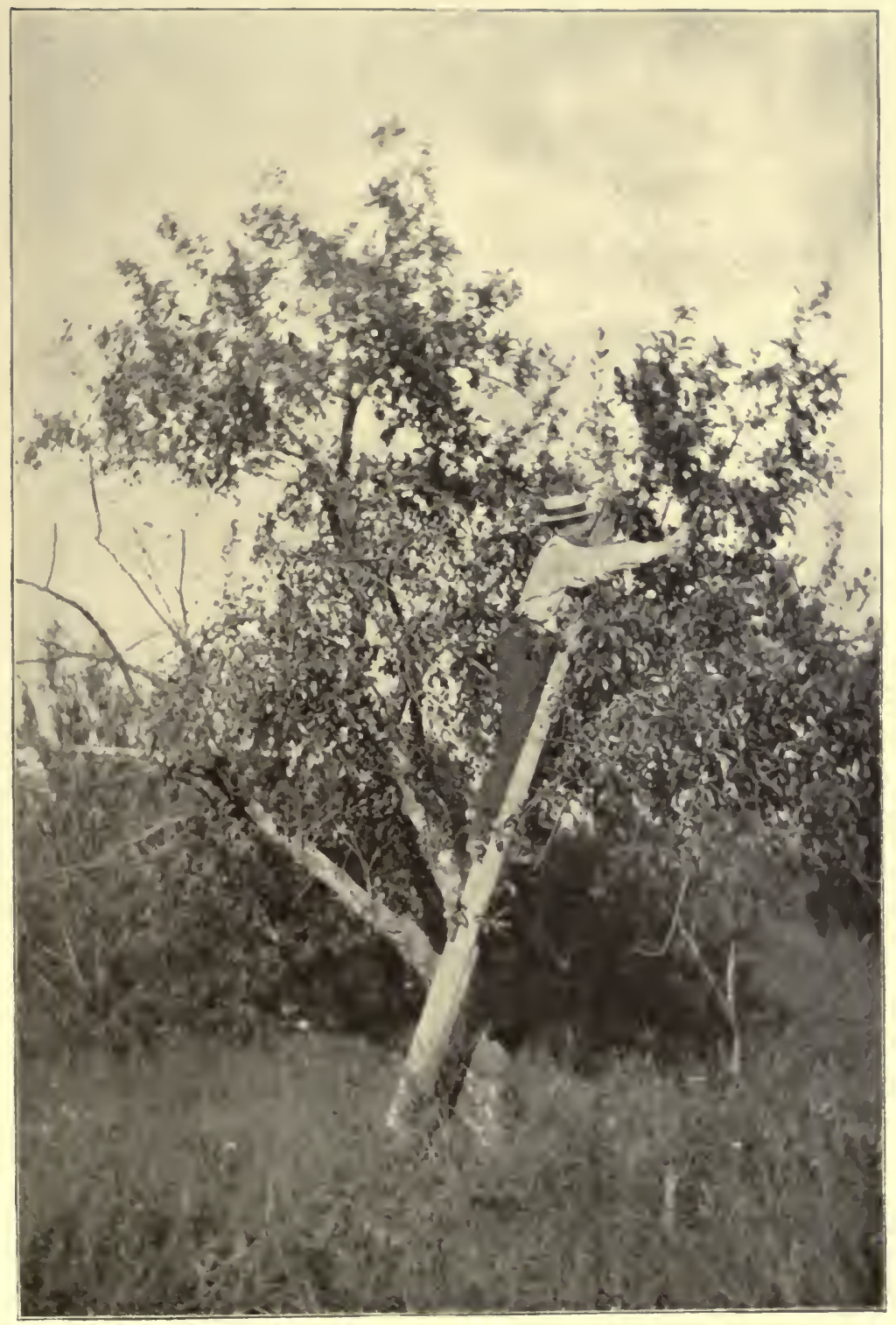

PICKING APPLES. 

their weight. I see them peeping at me from under every leaf, and hanging in innumerable sphericles, round shapes everywhere, ripe and ready for the harvest. I reach and pull them to me, and, turning one back a little, it breaks from its twig, dead ripe, and is soon fulfilling its intended usefulness; or perhaps, upon being jostled, one falls on my shoulder, in a tap, as it were, of friendly recognition, bidding its last goodbye, and then thumps and bounces at my feet. Others are not quite so mature, and these are the ones for the market. My sack is soon full, and I step down the ladder, and gently pour them out into one of the bushel baskets; another is soon emptying his, and before long the first basket is heaped and running over. Later, and these will all be hauled up to the barn, and there be still further sorted into four distinct classes: the ripe ones (to eat), the little, knotty, specked ones (for the hogs), the medium-sized ones (for the canning), and the large, fine-looking, imposing fellows (for the market). Sometimes, indeed, all these last do not find their way to a market, but go the familiar road of the kitchen and the evening circle about the fireplace.

I think if I have a favorite apple it is the fine old Tulpehocken (the Fallawater). There used to be, and is still, a moss-grown tree of that variety in the orchard, close to a dry brook-bed; and the great greenish balls would fall and slowly roll down the little slope, there to hide away among the weeds. I used to like to pick them out from the hollows and burrows which they had made for themselves amongst the leaves and grasses. They were sweet, but not too sweet; and they 
had enough of acid in them to give a rare delicacy to the taste. I have hid many a one away in the hay to give it time to ripen, gathering them a little early, perhaps, to be sure of them; and then right royal was the feast upon the big mellow globes. I see the teeth marks in them still; the rich pulp yields like flakes of snow, and melts as easily; one by one they disappear. The old tree has suckers all over it, and has been neglected, but it still bears, in my judgment, the finest apples in the orchard.

Some kinds of apples, like the Ben Davis, have a thick, leathery skin, almost a hide, to them; others, and most of them, have quite a thin skin, which crackles and tears apart easily as we bite it with our teeth. Some are greasy and sticky, like the Greenings, while others are almost slippery to the touch.

I like best the kind of trees that were grafted low, where the branches start to spread not over three feet from the ground. It is a pleasure to climb into such trees, and the apples at the ends of the boughs can be reached without great difficulty by single ladders, instead of necessitating a double ladder, and even then towering above us, as they frequently do in the older orchards, nodding away in derision, far up in the clouds. The older the trees get, in these orchards of our forefathers, the more inaccessible does the fruit become, until, as the lower limbs decay and are one by one lopped off, the only resort by which to obtain those great shining yellow orbs yonder on the tips is to make use of stones and clubs. It is said that some of the orchards until recently in existence hereabouts were planted by the redoubtable Johnny Appleseed, one of 


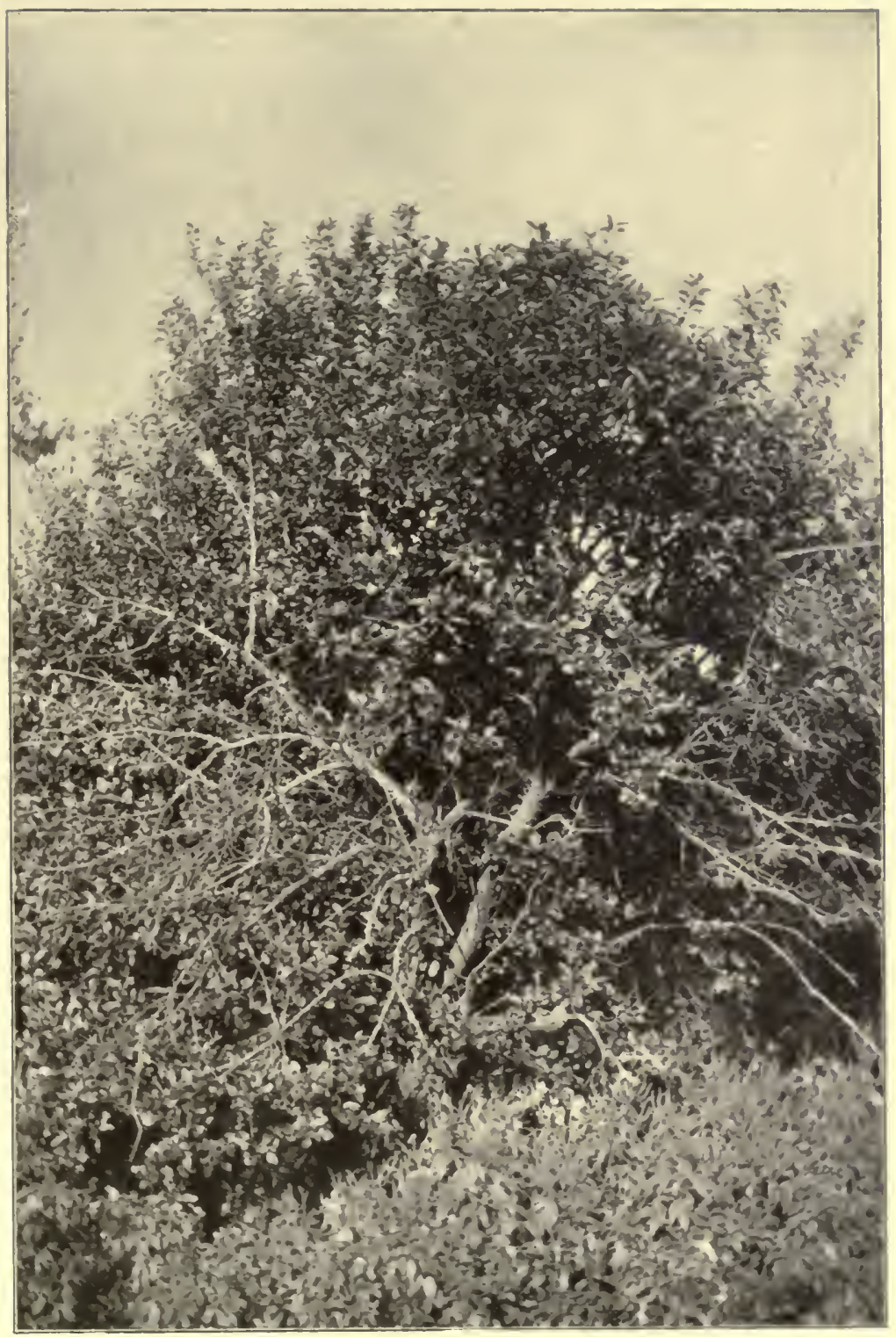

THE TULPEHOCKEN. 

the most singular characters in pioneer history, who roamed about through much of Ohio; and I have had such pointed out to me, though I can not verify their identification.

The cow likes to eat the apples, and she will keep the branches all browsed off as high as she can reach, if you put her in the orchard. But give her only sweet apples, as well as those only to horses also. I have always enjoyed feeding them to the animals. I have in mind one orchard in particular, which bordered a pasture, across whose blue grass hillocks the horses would come at a gallop when they would see me mount the fence and eye the trees. We used to bait our twitch-ups with tempting pieces of apple, but the squirrels, I fear, preferred the hickory nuts that ripened about the same time, although I have seen

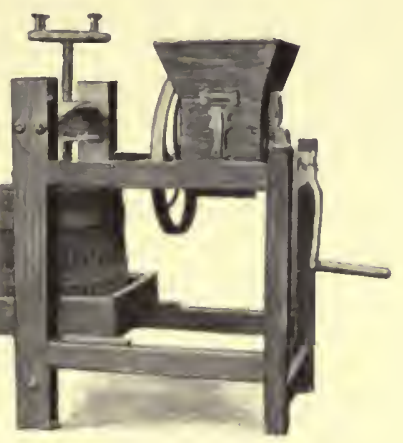

THE CIDER PRESS. them frisking and eating away among the apple boughs.

Some apples make better cider than others, but the Crabs are the best. Still, I would risk cider from almost any kind of apple. Cider-making is one of the most thoroughly enjoyable events of the year. What glorious fun it is to gather the great heaps of fruit in the orchard, as we drive the wagon along through the alleys between the rows of trees, and then to ride home with them, spreading forth sweetness everywhere as we pass. Then comes the getting out of the big cider press, and the dumping of the apples into its feeding- 
box. We begin to turn the handle; we hear the slicing of the apples as they are crunched and slivered by the knives; soon they fall in myriad flaky pieces into the receiving crate below (a sort of cylindrical rack, box, crib, or hamper, made of strong oak strips bound with iron, the ribs in the grating being slightly distanced from one another in a fine vertical open-work through whose interspaces the cider can easily gush when forced from the crushed fruit); this crate is removed as soon as full and placed under the presser, another is substituted in its place beneath the feeder; and the work begins afresh. Round and round we turn the screw that gradually compresses the ground pulp, until we soon see issuing from between the slats the first sweet tricklings. Lower and lower presses the block, harder and harder is the turning, until at last we must substitute for our hands a long stout wooden bar, one end of it to be inserted between the iron spokes which project upward from the rim of the hand-wheel on the screwhead, and the other end, smoothed for the grasp, to be pushed as a lever round and round and round, like a handspike in the socket of a capstan. Out comes the amber nectar, until the little conducting trough is completely inundated, and then it goes pouring in a tumultuous, frothy overflow into the foaming pails. When the last drop has been squeezed out, and it is impossible to force the block down further on the cheese, the press is then unscrewed; the dry, useless pomace now left in the crate is cast out into a wheelbarrow, and carted off as refuse, or is soaked for a time, and vinegar or jelly made from it; the fresh crate under the feeder is slid forward beneath the press; the 
old empty hamper is put again below the cutting box; then away goes the big rumbling wheel, the screw is twisted once more, and soon the rich pomade is oozing and dripping from its conduits as before. Shall we taste it? Who has the first glassful? ' $T$ is the ambrosia of the autumn.

I have been at cider-mills where the process was carried on by machinery on a much larger scale. There were tons of apples awaiting their demise, and wagon loads more of them coming; the constant hum of machinery was heard; the cider came running out of a spout in a perpetual stream into barrels; while back of the shed arose a mountain of the crushed and withered pomace- "apple chankin's," as they sometimes call them. In a little shanty in the rear of one of these mills that I used to enjoy visiting, came slowly dropping, bead by bead, the distilled essence of it all, genuine, transparent, sparkling arple brandy. Harmless, this? Try it, sir!

There is an old refrain, which I am sure most of us must have heard, with these familiar lines to it:

"The prettiest girl I ever saw

Was sucking cider through a straw."

It is a familiar picture, and I think I shall let it pass without further comment.

In Josiah Gilbert Holland's "Bitter-Sweet" is a stanza about the cider barrels which is here worth repeating :

" Sixteen barrels of cider

Ripening all in a row !

Open the vent-channels wider!

See the froth, drifted like snow,

Blown by the tempest below! 
Those delectable juices

Flowed through the sinuous sluices

Of sweet springs under the orchard;

Climbed into fountains that chained them ;

Dripped into cups that retained them,

And swelled till they dropped, and we gained them.

Then they were gathered and tortured

By passage from hopper to vat,

And fell--every apple crushed flat.

Ah! how the bees gathered round them,

And how delicious they found them!

In went the pulp by the scoop-full,

Till the juicc flowed by the stoup-full,-

Filling the half of a puncheon

While the men swallowed their luncheon.

Pure grew the stream with the stress

Of the lever and screw,

Till the last drops from the press

Were as bright as the dew."

There is but one long poem that I know of whose subject is wholly the poetry of cider-making; namely, "Cyder," by John Philips, far back there in the early eighteenth century-entirely unread nowadays, and yet standing, in the midst of those artificial, conventional, unnatural days, as a protest, and, even in its didactic, classical style, expressing an appreciation of country life. Keats, in his ode "To Autumn," in his imagination sees, as the crowning image, the spirit of the fall of the year seated beside a cider-press, as if this were the most natural, the most satisfactory, and the most representative picture he could give of the season:

" Or by a cyder-press, with patient look,

Thou watchest the last oozings, hours by hours."

Fresh cider, as it comes straight from the press, is indeed sweet and delicious. Yet to most people this wine from the apples tastes best after it has stood for 
a while and has fermented a little. It has then a tang and a sting to the tongue which add a delightful snap to it, and we drink it to the lees. Hard cider, of course, is as intoxicating as any other liquor much fermented. It is one of the enjoyments about the old fireplace to mull the cider-namely, to make a poker red hot, and then to plunge it in a jug, or pitcher, of the liquid. This causes it to sizzle mildly, and gives it a rich, burnt taste; and, when doughnuts are eaten with the cider, it is a fine treat. It goes along with nuts for the winter evenings. Our great-grandfathers, indeed, would have nothing of a common poker, but used, instead, a regular mulling iron and a flip glass for it. The iron was like a poker, but with the lower end greatly enlarged, and hexagonal or round in shape; and the flip glass, or mug, was very ornamental, and, tapering toward the bottom, flared out widely at the top, so as to receive the iron. The glass was warmed before the fire, and the mulling iron was heated in the embers; and a pretty, old-time picture it was, with the large, capacious glasses in rows before the hearth.

There is always something to do in the orchard. The weeds and briers must be tended to, and the poison ivy must be killed that so frequently makes its home among our apple-trees. We can hang our scythe conveniently in some of the gnarled and crinkled crotches. In the fall and spring there is plenty of work in taking care of the trees, cutting off the suckers, checking the growth where it has been too rapid, and generally thinning out the dying and superfluous branches; and these old dead limbs, when lopped off, make the best of firewood. Sound apple-wood, too, is very beautiful when 
polished, and highly prized. Ox yokes were sometimes made from the limbs. There is something very delightful in pruning. It is not hard labor, and it is always interesting to see the shape of a tree improve by our own trimming. In the spring we shall watch with solicitude to see whether the prospects for fruit are the better for it. Yes, we think the trees will blow well, so much was taken off that was useless; and, when at last almost every twig is pink, and the season turns out a good one, and the ripening spheres in autumn rouse our just pride, we say it pays to take care of the orchard. It is quite an art to dress trees well; for each variety has its own preferences of shape and ways of growing, and these must be studied in order to clean the tree to advantage, and so to produce the best crop. Yet every one can learn it, and it is a pleasure to do so. Nature will not take care of them very well for us. She expects aid at our hands, with our shears and knives and saws; and, unless we give it, she will forthwith cause such sprouts and tanglegrowth to spring up that it will be impossible for us to make much headway unless we clear them aside; and then, even after that, if we do not, she will either abandon the race and the tree will die, or she will bring a new tree from the old.

Apples attain to their best color when the orchard is on a hillside with a northern exposure. Then they paint themselves with the most delicate tints and the most gorgeous hues that the brush of autumn can splash upon them. Stained with their native yellow, they are yet often striped with some of the many variations of red, or even dashed with a shade of purple. 


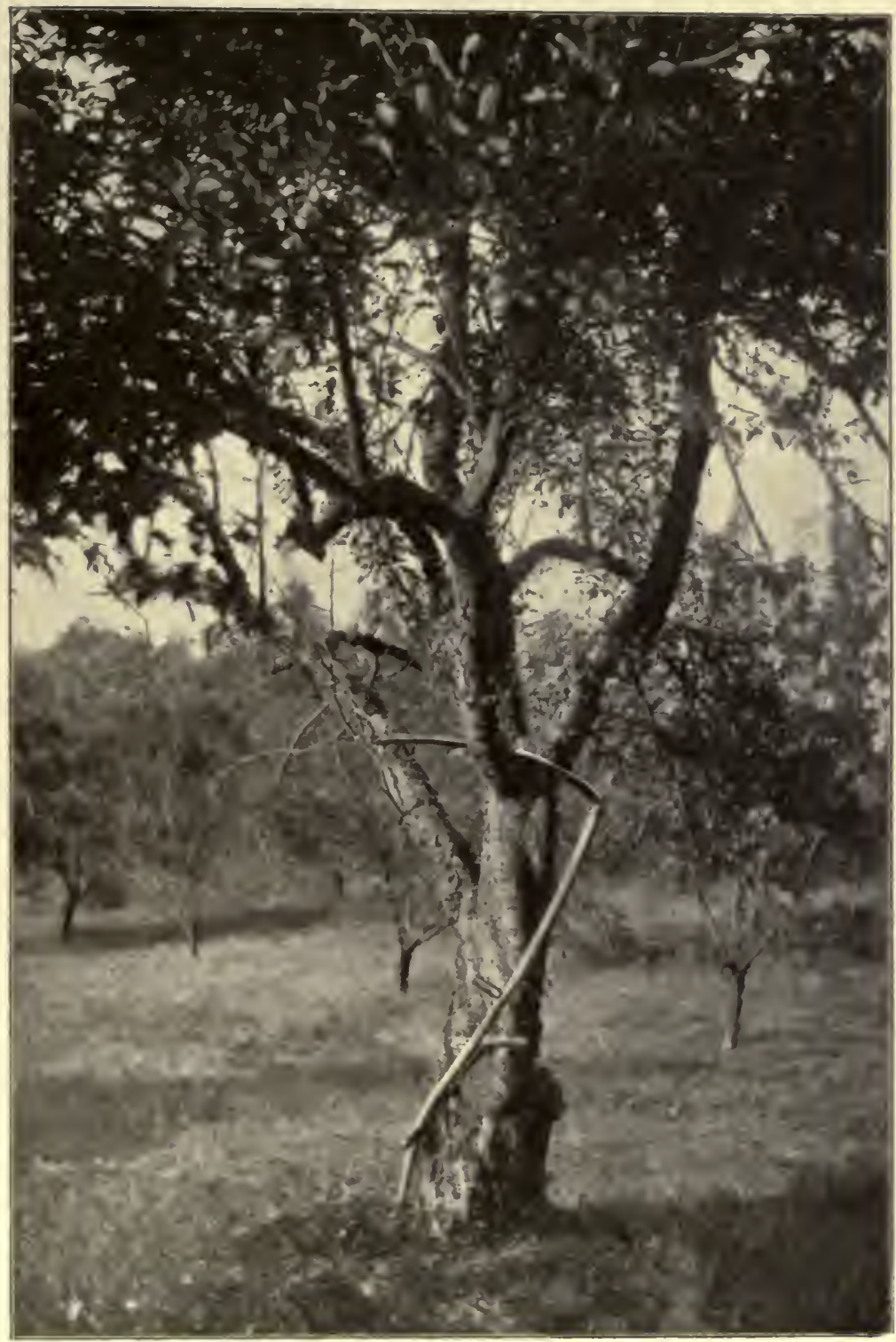

"We Can Hang Our Scythe Conveniently in Some of the Gnarled ant 17 Crinkled Crotches." 

I have noticed that those color best that have a full exposure to the sun. The fruit that is concealed too densely beneath the branches does not seem to have quite the vigor; the cheeks lack the glow of that which strings the outside twigs. It is said of the apples raised mainly by means of irrigation that they are tasteless, and lack the tang of ours that mature by a natural rainfall.

I like to cut into them, and to see what we used to call the "blossom" still evident in the lines and interior markings. Some apples are actually pink inside; some are a snowy white; others are the more usual yellow, or cream color, like the Russet. There is much difference, too, in the quality of the pulp, as well as of the skin. Some are almost brittle to the teeth, and snap off in flakes; some are soft and firm; still others are almost mushy when ripe. Some have tough, big cores; some have practically no cores at all. Some are racy, some insipid. Some are always small in size, while others will sometimes weigh a pound.

What a sweet smell comes from the bins of apples in the cellar, the blending of many odors, as we open the door to descend! Many a basketful is eaten by the firelight, with nuts and cake; and many a fine dish of fruit for dessert is formed during the autumn months of apples, and pears, and grapes from the vineyard. Apple pies, of every description, are a staple part of the pantry of every well-ordered household; apple sauce is a daily relish in its season; and the rich apple butter reminds us of the year that has gone all through the long winter.

There is no fruit so generaily useful as the apple, 
or that can be served up in so many ways. It is the mainstay of fruits, as if to atone for its traditional tempting qualities in the Garden. Having once unfortunately been the apple of discord, it has proved itself at last in truth to be golden, equal indeed to the apples of Hesperides. And so we keep it as the apple of our eye. The tree itself is the most graceful of all the fruit-trees. Other kinds of fruit, such as peaches, may be more pleasing at the time, but none stands the test so well throughout the year.

In early times they used to bury apples for the winter, and, when finally taken out, they had a peculiar earthy taste which was not unpleasant. None of the cold storage apples are so good, and yet none even of those stored in bins or buried are so sweet as those fresh from the trees.

Dried apples are also quite an accessory to the farm. In the old days nearly every farm had its shed, with its roof covered with split apples drying in the sun. They get calloused by this method, a sort of hard skin forming over them, which keeps the moisture in. For this purpose they used to have "apple cuttings," or "apple bees," at which the neighbors would come on an evening, and the gathering would then divide into two parties, each with an equal number of persons and a similar amount of apples, and then go it they would to see which would pare and slice the most. These would be strung sometimes on long threads, or strings, like onion tops, and then hung in great festoons about the walls. They do very well in winter-time, but these dried apples are not so good to eat, as such, as are dried peaches; they must be cooked into some 
sort of pie, or prepared in other ways, before they are palatable. An "apple bee" was different from a "corn husking," in that the women could more generally take part; but it was like one in that it usually wound up with a dance or the Virginia reel. It was always seen to it that a fiddler was among those asked to attend. "Bobbing" for apples in a tub of water was a sport for Hallowe'en.

The orchard is a great place for the birds in the spring. I see little gleams of yellow, and blue, and red, with glimpses of the more somber brown, dart from tree to tree and flit among the branches. It seems to be the favorite home of the yellow-breasted chat, as he talks away at us or cooes and warbles from among his leafy coverts. The robin also homesteads among its crotches. The bluebird makes her nest in a hollow limb; or enters by some knot-hole into the dim fastnesses of the trunk, and there rears her young. Orioles hang their abodes from the tips of the branches. The little chickadees peep about in their endless search up and down the bark and about the sprays. Woodpeckers tap the trees with their bills, and some old orchards are literally riddled and tattooed from head to foot with the bullet-like perforations of their drilling. Perhaps a dove will construct her simple dwelling on a bough, and we shall hear the mournful gurgle of her mate while they select their site. From everywhere, from every tree, and of tentimes apparently from nearly every bough, comes the tireless and incessant love-fluting of the birds. And not only while mating, but also during nesting time, while the female sits on the nest, does that speckled beauty, the wood thrush, 
yodel away his bursts of song in the dying day. A poetic way, this, of nesting in the orchard. The first brood, perchance, is hatched while blossoms still whiten the boughs or the ground is strewn with petals, and the last is reared amongst the golden globes.

Wilson Flagg once "made an interesting study of the "Birds of the Garden and Orchard," enumerating quite a coterie so inclined; and it was in the course of that series of sketches that he inserted his really inimitable poem, "The O'Lincoln Family," on the bobolink. Flagg also continued his bird papers in a further and no less interesting series, upon the "Birds of the Pasture and Forest," "Birds of the Night," and others.

Sheep like to graze in an orchard upon the orchard grass, or the blue grass, or red top, or the many weeds which they think are so succulent. It is a good way to keep the orchard clean and free from weeds and briers, to have a small flock of sheep running in it. They form a pleasing picture as they placidly and contentedly chew their cud beneath the apple-trees.

Butterflies, some large and some small, flutter about and light on the apples that lie on the ground; bees buzz among them, and extract the nectar of the bruised and fallen fruit; insects quickly crawl over them, and taste their sweetness. I like to lie upon the grass beneath these trees, even if for no other purpose than simply to look up at the leaves and the fruit. It was in an orchard that Sir Isaac Newton discovered the law of gravitation, as he heard the perpetual thuds of the great round things as they fell to earth. Richard Jefferies wrote his immortal "Pageant of Summer" beneath an apple-tree. 
But the orchard may stand for a group, or a setting, of fruit-trees other than apples. There are several other orchards about the homestead. The cherries ripen the earliest, with their round crimson fruit. Then come the apricots and peaches, all covered with down; next the plums, great long ropes of them dangling there, with the hogs roaming and rooting around beneath them for those that fall; along with the plums come the pears and apples; and, lastly, the fuzzy, lemon-colored quinces. What a variety there is in these fruits-sweet and sour cherries; white and yellow, early and late, freestone and clingstone peaches; the blue, green, red, and yellow plums, almost like tropical fruits in their nature; and all the different kinds of pearsthe juicy Clapp's Favorite, the winy Flemish Beauty, the sugary Seckel, the luscious Bartlett, and the others. Now all these belong to the order Rosacea, and yet what a vast difference in the quality and nature of the fruit. But there they are, pomes or drupes or whatever you wish to call them, each ripening for us in its season amongst the twigs and leaves.

Mr. John Burroughs has written a paper upon "The Apple," which is everywhere redolent of the bin and the orchard. I shall give you the pleasure of these few sentences from it:

"Noble, common fruit, best friend of man and most loved by him, following him, like his dog or his cow, wherever he goes! His homestead is not planted till you are planted, your roots intertwine with his; thriving best where he thrives best, loving the limestone and the frost, the plow and the pruningknife; you are indeed suggestive of hardy, cheerful industry, and a healthy life in the open air." 
Mr. Burroughs thinks it a sure sign of age when a man no longer cares for apples, and in another of his papers says that his old hollow apple-tree, unlike most persons, always wears "a girdle of perpetual youth" in the new green ring which annually surrounds its trunk.

Bryant has a poem entitled "The Planting of the Apple-Tree," this stanza of which is especially suggestive :

"What plant we in this apple-tree?

Fruits that shall swell in sunny June, And redden in the August noon, And drop, when gentle airs come by, That fan the blue September sky,

While children come, with cries of glee, And seek them where the fragrant grass

Betrays their bed to those who pass At the foot of the apple-tree."

In Holland's "Bitter-Sweet," again, is another fine description of the varieties of apples in the bins near the barrels of cider in the cellar, as follows:

"That is a barrel of russets ;

But we can hardly discuss its

Splieres of frost and fint,

Till, smitten by thoughts of spring,

And the old tree blossoming,

Their bronze takes a yellower tint,

And the pulp grows mellower in 't.

But oh! when they 're sick with the savors

Of sweets that they dream of,

Sure, all the toothsomest flavors

They hold the cream of!

“Those are the Rhode Island greenings;

Excellent apples for pies : 
There are the Baldwins and Flyers,

Wrapped in their beautiful hres!

Color forks up from their stems

As if painted by Flora,

Or as out from the pole stream the flames

Of the northern Aurora.

"Here shall our quest have a close:

Fill up your basket with those ;

Bite through their vesture of flame,

And then you will gather

All that is meant by the name,

'Seek-no-farther.'"

But perhaps Thoreau's essay upon "Wild Apples" is the best known, as it is also the raciest in its style and appreciation. How he enjoyed them! Let him tell his own story of his gleaning, in a passage justly famous as perhaps the classic in the literature of the apple :

"I know a Blue-Pearmain tree, growing within the edge of a swamp, almost as good as wild. You would not suppose there was any fruit left there, on the first survey, but you must look according to system. Those which lie exposed are quite brown and rotten now, or perchance a few still show one blooming cheek here and there amid the wet leaves. Nevertheless, with experienced eyes, I explore amid the bare alders and the huckleberry-bushes and the withered sedge, and in the crevices of the rocks, which are full of leaves, and pry under the fallen and decaying ferns, which, with apple and alder leaves, thickly strew the ground. For I know that they lie concealed, fallen into hollows long since and covered up by the leaves of the tree itself,-a proper kind of packing. From these lurking places, anywhere within the circumference of the tree, I draw forth the fruit, all wet and glossy, maybe nibbled by rabbits and hollowed out by crickets, and perhaps with a leaf or two 
cemented to it (as Curzon an old manuscript from a monastery's moldy cellar), but still with a rich bloom on it, and at least as ripe and well kept, if not better than those in barrels, more crisp and lively than they. If these resources fail to yield anything, I have learned to look between the bases of the suckers which spring thickly from some horizontal limb, for now and then one lodges there, or in the very midst of an alderclump, where they are covered by leaves, safe from cows which may have smelled them out. If I am sharp-set, for I do not refuse the Blue-Pearmain, I fill my pockets on each side; and as I retrace my steps in the frosty eve, being perhaps four or five miles from home, I eat one first from this side, and then from that, to keep my balance."

And with his words I close my paper, hoping that we shall all see our bins and barrels full for the winter.

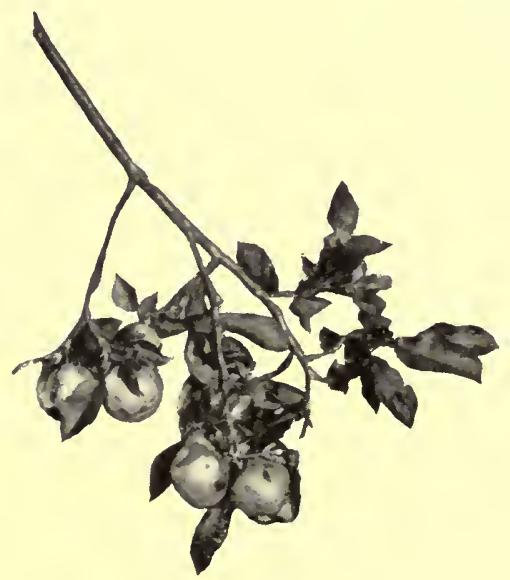

A BOUGH OF APPLES. 


\section{HARVEST.}

"Fling wide the grain; we give the fields

The ears that nod in summer's gale,

The shining stems that summer gilds,

The harvest that o'erflows the vale,

And swells, an amber sea, between

The full-leaved woods, its shores of green.

Hark! from the murmuring clods I hear

Glad voices of the coming year;

The song of him who binds the grain,

The shout of those that load the wain,

And from the distant grange there comes

The clatter of the thresher's flail,

And steadily the millstone hums

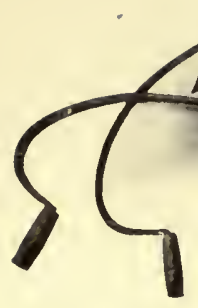

Down in the willowy vale."

HE term harvest, as it is generally understood in the country, is limited to the time when the ripened grain is cut and garnered into the barns. Yet the real harvest lasts longer than that. The berry season and haying sickles. immediately precede and often accompany the reaping of the grain, and we are surely still getting in our crops when we pick the last apple of October. Are not these, then, also a part of the harvest? Indeed, all summer and autumn, even till the last stalk of corn is cut and the rustling shocks lie scattered in corn husking in November, are but the gathering in of the products from the seeds of the previous fall and the blossoms of the spring.

Let us turn to the hayfield while the men are there. It is no wonder the cows love clover. See it turn over, 
with its pink blossoms, as the mower cuts it! Aye, 't were better could we but see more of it. There are some fine lines in one of Joaquin Miller's poems, "The Arizonian:"

"And I have said, and I say it ever, As the years go on and the world goes over, ' $\mathrm{T}$ were better to be content and clever, In the tending of cattle and the tossing of clover, In the grazing of cattle and growing of grain, Than a strong man striving for fame or gain, Be even as kine in the red-tipped clover;

Be even as clover with its crown of blossoms, Even as blossoms ere the bloom is shed, Kiss'd by the kine and the brown sweet bee."

Whittier felt the poetry of hay-making. His "Maud Muller" is probably the best known poem on the subject, and is familiar to everybody. It is not an uncommon picture; yet would it were even more common, and that sunbonnets and torn hats were not going out of fashion:

\footnotetext{
"Maud Muller, on a summer's day, Raked the meadow sweet with hay.

"Beneath her torn hat glowed the wealth of simple beauty and ristic health."
}

But haying is hard work, and the men benefit by it only indirectly. Hay is for horses and stock. Yet the men work the hardest in the fields, while the horses merely draw the loads, and wait while the men pitch on the hay or unload it into the mow. It is a case, in this instance, of the servant being greater than his master; but the master generally manages to make up 


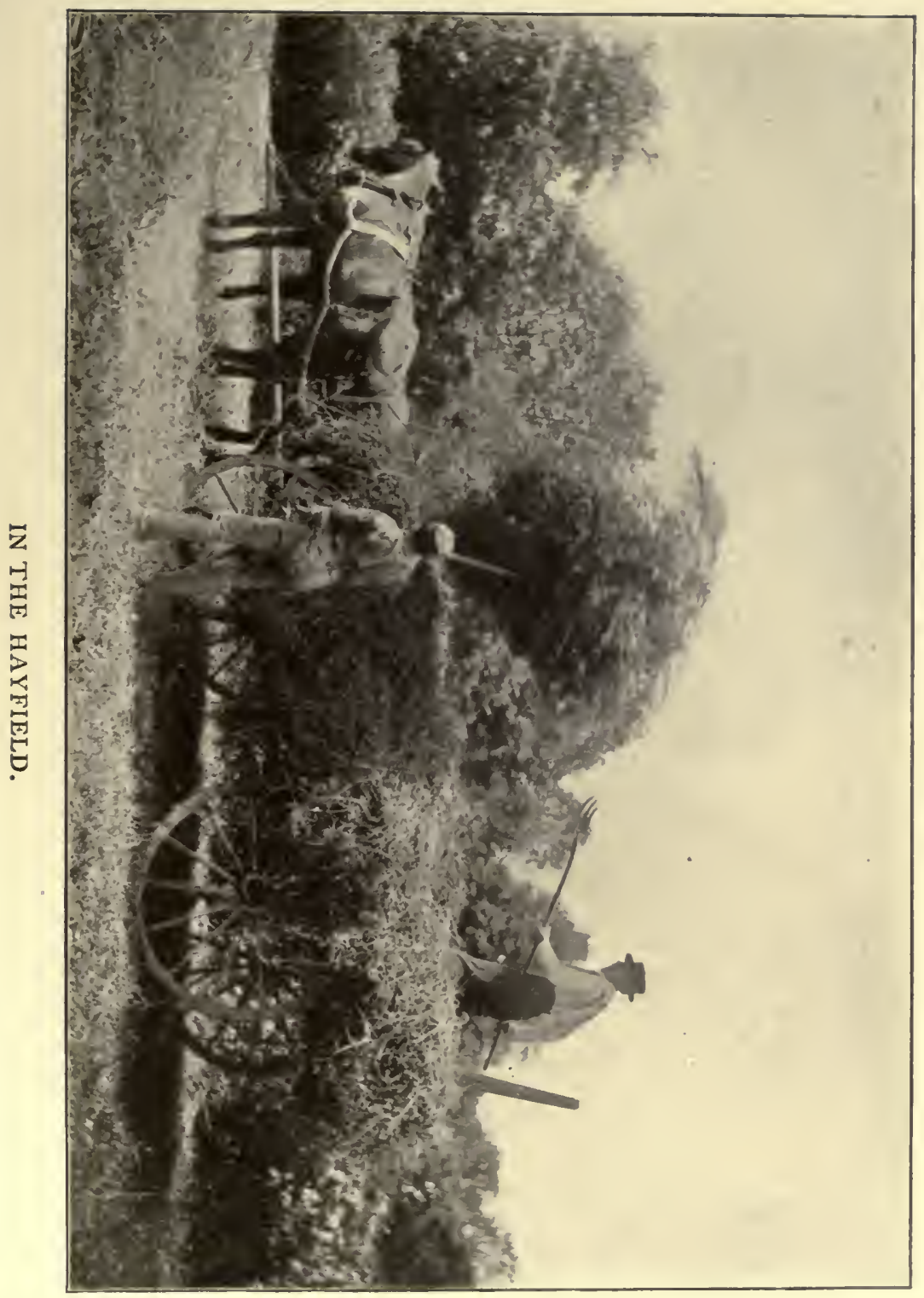



for it, and gets even in the plowing season. Sometimes hay-making becomes a great frolic, and the children climb on the loads, and happy are the long rides from the field while they nestle among the fragrant grasses. I have even seen a fiddle go to the field with the jug, when the meadows were far distant fiom the farmhouse; and the laborers would then stay out for some days, until all was cut and stacked.

Whitman has left a realistic picture of the return of the load to the barn:

"The big doors of the country barn stand open and ready,

The dried grass of the harvest-time loads the slow-drawn wagon, The clear light plays on the brown gray and green intertinged,

The armfuls are packed to the sagging mow.

"I am there, I help, I came stretch'd atop of the load,

I felt its soft jolts, one leg reclined on the other,

I jump from the cross-beams and seize the clover and timothy,

And roll head over heels and tangle my hair full of wisps."

You must be careful not to get mixed up in a bumble-bees' nest in the field. They are very irascible customers. And yet I knew of no better fun as a boy than to stir up a nest, and, armed with leafy branches or a bunch of weeds, to fight my way right among them, and finally, after the massacre, secure the little eggshaped globules, of cocoon-like covering, that contained the honey. Bumble-bee honey is stronger than the honey-bee's, but it has a sort of wild taste, and serves very well to vary the monotony in the haying season. The big yellow-banded fellows-regular ogres, so cross are they-seem to choose a clover field above all others for their domicile. If they sting the horses, you will have a time of it, and may get the harness all broken 
and tangled before you get through, and perhaps the mowing machine itself will get into bad order.

Sometimes a turtle or two will be found amongst the clover, or a snake is cut to pieces in the hayfield. I know of a man who cut off the heads of two big black snakes in a small field, unintentionally, with the knife of his mower. They were lying coiled in the clover, with their heads raised a little, and the Juggernaut came along and slivered them. Sometimes a dog will come too close, as he bounds about after a rabbit, and perhaps he will be badly mangled, and may have to be killed.

It is quite a trick to know how to pitch hay, and to gather all into one bunch clean with a fork, without the necessity of a hand-rake following; and it is an even greater trick to load the hay properly, so that it will not slide off on side-hills; and a still greater one to form and top off a stack. Mowing away is not such an art, nor is the boys' job of treading the hay downbut ah! brethren, many a drop of genuine sweat has glistened in the hayfield and the loft. If there is a time when a man can enjoy a refreshing drink from the bucket at the well, it is after pitching off a load of hay. So, sings Woodworth, in the well-known lines:

"That moss-covered vessel I hailed as a treasure;

For often at noon, when returned from the field, I found it the source of an exquisite pleasureThe purest and sweetest that nature can yield.

How ardent I seized it, with hands that were glowing, And quick to the white-pebbled bottom it fell! Then soon, with the emblem of truth overflowing, And dripping with coolness, it rose from tle wellThe old oaken bucket, tle iron-bound bucket, The moss-covered bucket, arose from the well." 


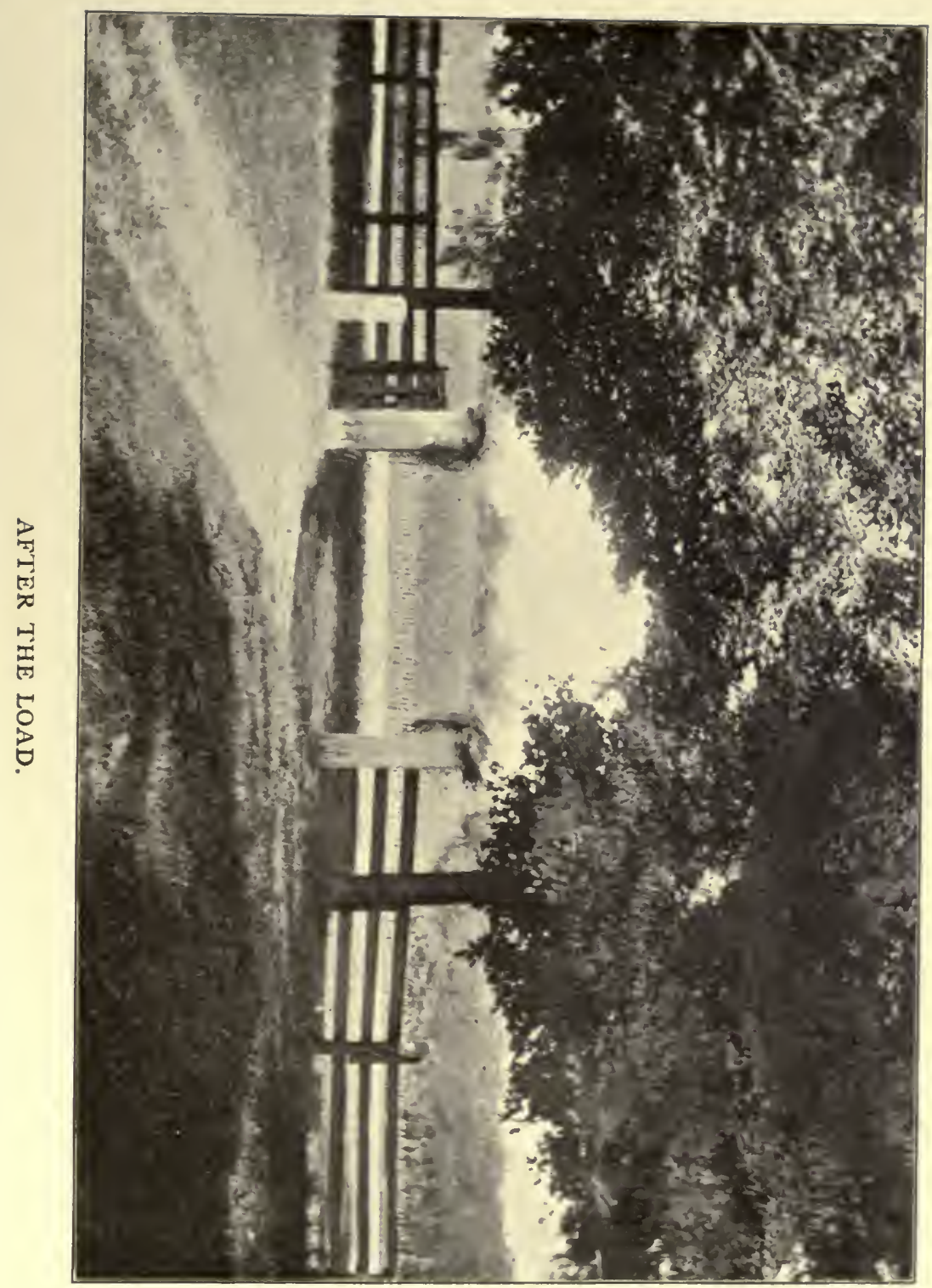

I8 

And if there is a time when a man can relish a bath, or, better still, a plunge in a pond or a brook, it is in the twilight after a day's work with timothy or clover, when the seeds have simply tattooed him from head to foot in innumerable, speckled, itching spots of red.

We see wisps of hay hanging from the gateposts where the wagons have passed through, and strands cast along the roadside and in the barnyard. Out on the hillside, in the orchard, they are still cutting. There will be a good load or two more of it. The sweet scent of new-mown hay is wafted to us as we lie in the shade. We can see the mowers bending and swaying at their work. At times one will rest, and then the musical whetting of his scythe soon reaches our ears. Let us go down among them. The erect grasses, with their slender stems and nodding tops, fall one by one before the steady slash of the blade, and at each stroke are bunched by the mower with the heel of his scythe and laid in a windrow along the swath. Perhaps, later on, these same long lines of damp green grass will be tossed and scattered to dry in the wind and the sun, and then afterwards raked together again or forked into haycocks to shed the rain. There are few more interesting things to watch or to do on a farm than the cutting of grass with a scythe.

"O sound to rout the brood of cares,

The sweep of scythe in morning dew,"

sings Tennyson.

Mr. Andrew Lang's "Scythe Song" gives such a lovely picture of the mowers, and so perfectly repro- 
duces the sound of the scythe, and interprets it so well, that I shall here transcribe it:

"Mowers, weary and brown, and blithe,

What is the word' methinks ye know,

Endless over-word that the Scythe

Sings to the blades of the grass below?

Scythes that swing in the grass and clover,

Something, still, they say as they pass;

What is the word that, over and over,

Sings the Scythe to the flowers and grass?

"Hush, ah hush, the Scythes are saying,

Hush, and heed not; and fall asleep;

II ush, they say to the grasses swaying,

Hush, they sing to the clover deep!

Iush,-'t is the lullaby Time is singing-

Hush, and heed not, for all things pass,

Hush, ah hursh! and the Scythes are swinging

Over the clover, over the grass!"

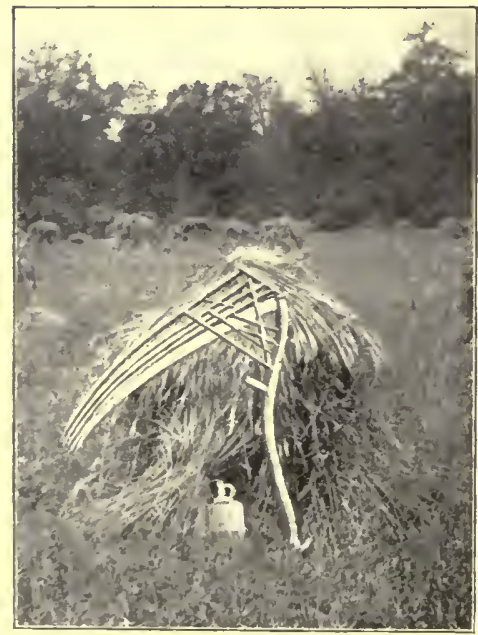

" little brown Jug, do N'T I love THEE!',
No part of the year is more poetic in the whole round of farming than haying and grain harvest. The farm that does not have its grassy meadows and fields of wheat, with all the life and scenes of the harvest-time, is no farm at all. The harvest is the most picturesque work of the year, as well as the most romantic. Sugar-making alone can approach it. It is the delight of memory to recall the dinners brought out in pails to the fields, the cool drink from 
the jug, and the hours spent in lying among the sheaves at rest. There is more poetry in the oldfashioned ways, in the rasp of the sweeping cradle, the sheaves bound together with handfuls of the same wheat straw, the curved hand sickle hook, the swish and delicate tang of the scythe as it slips through the tall grass.

That is a pleasant glimpse of old-time custom which

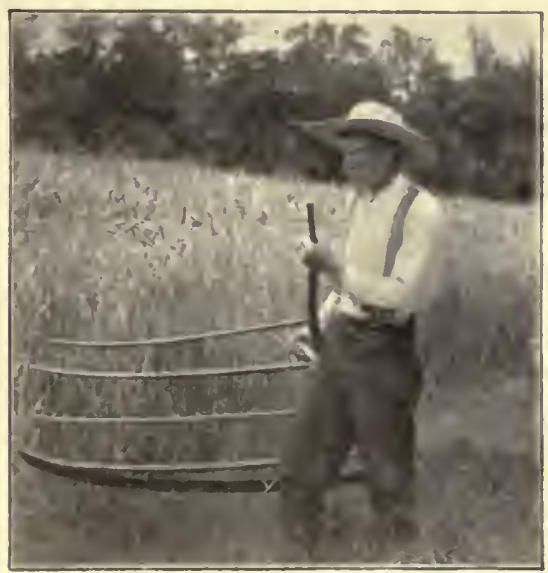

CRADLING WHEAT.

Alice Cary has left to us, in her poem entitled "Harvest Time," in this opening stanza:

"God's blessing on the reapers! all day long

A quiet sense of peace my spirit fills, As whistled fragments of untutored song

Blend with the rush of sickles on the hills: And the blue wild-flowers and green briar-leaves Are brightly tangled with the yellow sheaves." 
Modern improvements, however, have not greatly lessened the picturesque sides of country life, and they have vastly diminshed the hard labor. It is almost as enjoyable to see the mower seated on a machine drawn

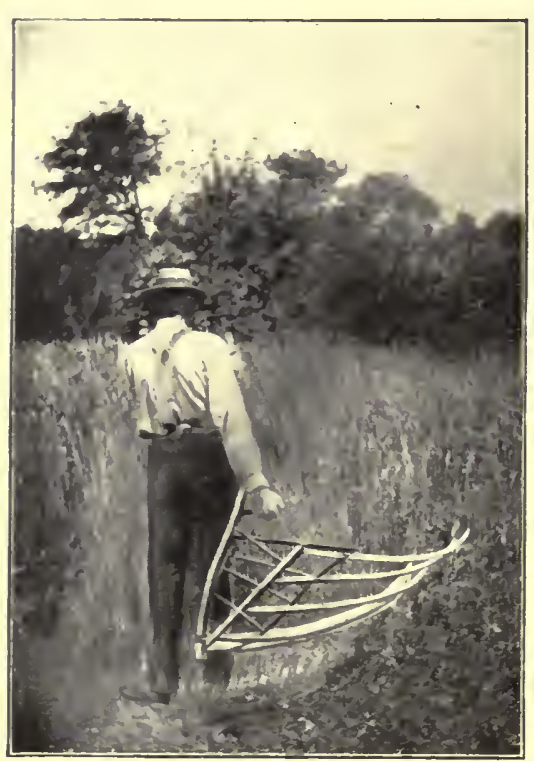

THE OLD-TIME WAY. by horses as to watch him swinging the scythe, and the blades of grass fall more rapidly than in the older way. Indeed, not only is the clover practically all cut by machinery nowadays, except in the few inaccessible spots where the scythe is needed or where the stems are badly matted down, but it is also generally all raked together with the aid of horses and a horse-rake, while the hand-rake hangs unused in the barn. I have even worked in the fields where almost all pitching was obviated, and the stacking done with a great toothed bucking beam pulled by two horses at each end along the windrows; and, again, where the hay itself was all mechanically brought up from the windrows on the carrier of a combined rake and loader, attached to and trailing after the wagon, and then spread out upon slings on the rigging, thence afterwards to be hoisted in enormous flaky masses to the stack by a block-and-tackle and a derrick. 
In fields, too, where formerly the harvesting was all done by hand with the old-time notched and serrated sickles, or reaping hooks, requiring a dozen men or over for a single field and necessitating endless hours, one can hear to-day the click-click-click of the modern knives in their cutter-bar as the horses draw the reaper, and can see the arms of a selfbinder turning over and over and waving above the sea of wheat, gathering in the golden spears. Out on the stubble one by one fall the bundles, sheaves already tied up with good strong twine, a much more easy way of doing it than the old method of the cradle, a rake, a gavel, and a wisp of straw.

And then comes the shocking of the grain, either in long or round shocks as you please, the bundles being placed regularly

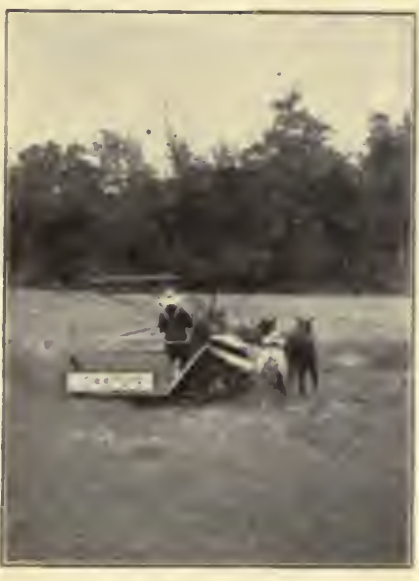

MODERN HARVESTING. together, a dozen to the shock, with a couple of straddling riders, or "hudders," on the top to shed the rain. After drying for a few days in the shock, the grain is next either hauled to the barn and mowed away, or else is stacked near the house, where it goes through a period of "sweating," or thorough evaporation of the moisture it contains, before threshing. Sometimes, however, if it is cut when quite ripe, the grain is hauled direct to the threshing machine in the field, where, amid a great, thundering, rough rhythm and a shower of dust, the kernels, or berries. 


\section{AROUND AN OLD HOMESTEAD.}

of the wheat are separated from the straw and chaff, and come pouring out in a steady stream from a spout into the sacks or other measures, while the straw and chaff is conveyed up on a long elevator and let fall to the ground at its end, where men stack it, or else is blown through a long

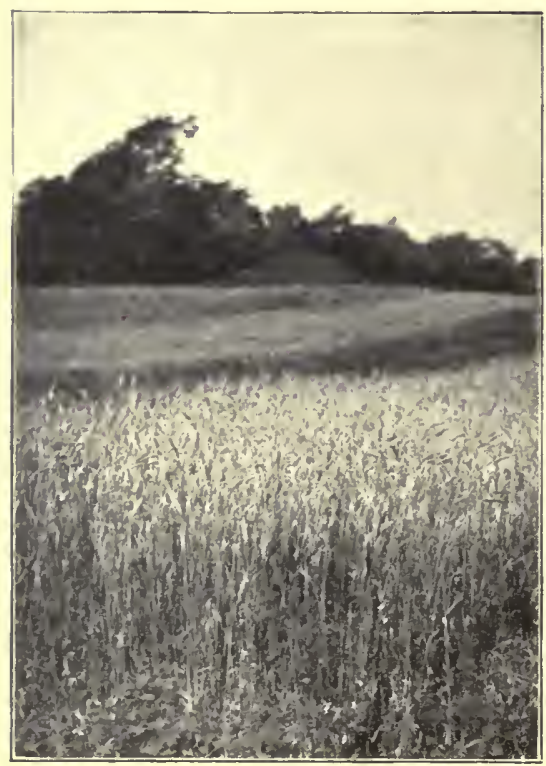

“' WhAT SHALi THE HARVEST BE ?" movable funnel and is stacked automatically.

This, then, is the height of harvest, when the farmer can see dollars in sight, and has the final recompense for all his long labor. It is the hardest work of the year, and the hottest, e a rly hours and late, and short noons; but when it is all over, and the wheat is stored away in sacks, or lies in a great brown heap on the barn floor, ready for sale, or is packed away in a granary for winter, then it is with much relief that the farmer can turn to the fall work, - the plowing for next year's grain, the sowing of it, the picking of the apples, the cider press, the pruning of the orchard, the cutting of the tasseled maize, the gathering of the pumpkins, corn husking, and the sawing of the winter wood.

Practically the same process is gone through with 
in the case of barley, oats, flax, and rye as with wheat, only the riddles, or screens, are changed in the thresher. Sometimes, if the harvest is small, the threshing is delayed until perhaps in October, when the machine can best attend to these lesser jobs; or it is put off still further till winter, and then the grain is tramped out of the heads by horses, or beaten out by a flail (we can hear the dubbing of the swipple as it hits the barn floor), and the straw is raked off, and the wheat is winnowed and cleaned from the chaff and dust in one of the old-time hand-turned fanning mills.

It is all of it interesting work to one who loves the country; and, as I have said of haying, a good swim in a pond or a brook in the evenings, under the lustrous harvest moon, after the work is over, to wash off the perspiration and the pieces of chaff and straw, is equally pleasurable. But, while enjoyable work, scythes and cradles and sickles and knives must all be sharpened, and many a boy has got his start in life turning the grindstone for his father. The boy will have to be careful in handling the sheaves, or he may find himself scratched by a briar which has been bound up with the wheat; and he must be careful not to get a beard of barley down his throat, and not to run too swiftly barefoot in the stubble. Not many children that have ever been on a farm in threshing-time have gone through it without chewing a handful of the grains of wheat into "wax," which, with gum from the cherry, spruce, and sweet gum trees, is the country's substitute for the manufactured "chewing gum" of the city; and few also but have made oat whistles from a straw, or cornstalk fiddles from a cane of maize. 
In the early days the farmers occasionally used the hollow stumps of sycamores as their granaries, boards being laid across the top as a covering, or roof; and these hollow stumps, cut high purposely and sometimes being very wide and deep, held a great deal of grain. Some of these old sycamores were really giants, and all generally very hollow at the base; and, when these big cavernous stumps were filled to the overflowing, they contained more grain than would ordinarily be imagined. They served the purpose well, and were very valuable adjuncts of Nature to the barn. I know of one still in existence, which is now up on props and is used as a corncrib.

The raising of field corn, or the Indian maize, is one of the largely followed branches of farming in the South and West. Most of the work of harvesting it on large tracts of land is all done now by horse-drawn corn cutters. But it is a pleasure to slash away with a corn knife among the rustling leaves; and then to pile your armfuls together slantingly in a shock, around a "buck" made of the bent-over stems from four adjoining "hills;" and later to bind the tops together with a twisted rope of the stalks themselves. "Corn huskings" and "apple bees" in the old days were great occasions, and lots of fun; and people entered into the work of it willingly, and with no thought of pay, in a way they would hardly do nowadays. Nowadays it is generally all husked by hand in the field, with the aid of a stout metal, bone, or wooden peg, bound by thongs to the fingers, with which the shucks are easily torn apart to the ear; or is husked, and the fodder shredded at the same time, by machinery. But in an 
old-time "husking bee" the ears were all torn off from the stalks, and were heaped in great piles either on the barn floor or on a clean plat of grass in the yard. The neighbors invited would gather in, divide into parties (as at a spelling match), and see which side could get the most ears in the husking, the reward for the victors being the first swig at the jug. In some localities it was the customary understanding that whenever a girl happened on a red ear in the husking it was the privilege of all boys present to kiss her; and the corresponding prerogative of whatever boy shucked such an ear to invade the fair ones, and forthwith to kiss unchallenged the girl he liked the best. Thus the girls had the best of it in either case; and many a love story has started from the husking party. Rarer even than red ears, though, were those having an uneven number of rows of kernels, which generally are arranged evenly on the cob in rows of two and two. It was quite an achievement to have the luck to find such an ear. If there was a fiddler in the neighborhood (as there was apt to be), he would always surely be invited; and, while the girls were in the house, getting the doughnuts and cake and cider, the men cleared off the barn floor ready for the dance.

The harvest-home festivals of our generation, when the choicest fruits, and samples of grain, and stock are submitted in good-humored competition for premiums, are but a survival of the old English custom of celebrating the homing, or final garnering, of the harvest with merrymaking and feasting. We in our day, too, are always glad when the crops have been gathered, so much so that the countryman does not shrink from 
prolonging the ceremonies with good things the whole year round. Hamerton, I remember, in "The Sylvan Year," has left a delightful picture of the harvest-time. ${ }^{1}$

Ceres was the old Roman goddess of plenty; and it was fitting that one of the best of Shakespeare's songs should have been that of Ceres, in "The Tempest," in blessing Ferdinand and Miranda:

\footnotetext{
"Earth's increase, foison plenty, Barns and garners never empty; Vines with clustering bunches growing;

Plants with goodly burthen bowing; Spring come to you, at the farthest, In the very end of harvest ?

Scarcity and want shall shun you;

Ceres' blessing so is on you."
}

Iris, also, in the same play, calls some reapers from the fields to join in a dance with nymphs in honor of the same twain:
"You sunburnt sicklemen, of August weary, Come hither from the furrow, and be merry. Make holiday; your rye-straw hats put on, And these fresh nymphs encounter every one In country footing."

I am reminded, from these thoughts upon the harvest, of the most beautiful book in the Bible, the story of Ruth the Moabitess; of her gleaning after the reap-

${ }^{1}$ Since writing the above I have come across a very delightful ciescription of an old-time "husking bee" out in the barn, and the frolic afterwards in the spacious kitchen, with its apple-hung rafters, in a charming book of outdoor sketches, upon another "old homestead," this time in New England, in a sketch entitled "Mist," in Mr. Herbert Milton Sylvester's "Prose Pastorals." 
ers in the field of Boaz, "unto the end of barley" harvest, and of wheat harvest;" of his generosity in having some of the grain purposely let fall for her; of her own beating out of the barley she had gathered; of the picture we have of the customs and life far back there about the town of Bethlehem ("Behold, he winnoweth barley to-night in the threshing floor"); and of all the rest of that poetic Hebrew pastoral. The harvest in Bible times was an important season of the year, and frequent references are made to it as designating the time of some occurrence. The reaping was, of course, all done in the original way, by grasping a handful of the grain and cutting it off with a sickle. David describes the process indirectly, by comparing the wicked to grass which has withered before it is grown, "wherewith the mower filleth not his hand, nor he that bindeth sheaves his bosom." Frequent mention is made also of the threshing floor, where the grain was winnowed in Nature's own method, by the fanning and sifting of the driving winds. It was one of the kindly precepts in the Mosaic law that "thou shalt not wholly reap the corners of thy field, neither shalt thou gather the gleaning of thy harvest," but they were to be left "for the poor and for the sojourner." One of the finest of the parables is that of the sower; and the harvest, by a figure, is made the end of the world.

The harrest is thus always associated in our minds with the pursuits of peace and quiet country life. It is a prophecy which men still hold dear that some day, in "that good time coming," the nations "shall beat 
their swords into plowshares, and their spears into pruning hooks," and so, in Shakespeare's fine old line,

"To reap the harvest of perpetual peace."

And it is another of the promises, and one of the most beautiful of all in its simplicity, that, with the bow in the cloud as the token of the covenant,

"While the earth remaineth, seedtime and harvest, and cold and heat, and summer and winter, and day and night, shall rot cease."

Whittier has left "A Song of Harvest," and I know of no more fitting sentiment with which to close these random observations than his beautiful stanzas:

"O Painter of the fruits and flowers!

We thank thee for thy wise design

Whereby these human hands of ours

In Nature"s garden work with thine.

"And thanks that from our daily need

The joy of simple faith is born:

That he who smites the summer weed

May trust thee for the autumn corn.

"Give fools their gold, and knares their power;

Let fortune's bubbles rise and fall;

Who sows a field, or trzins a flower,

Or plants a tree is more than all.

"For he who blesses most is blest;

And God and man shall own his worth

Who toils to leave as his bequest

An added beauty io the earth. 
"And, soon or late, to all that sow

The time of harrest shall be given;

The flower shall bloom, the fruit shall grow, If not on earth, at last in heaven."

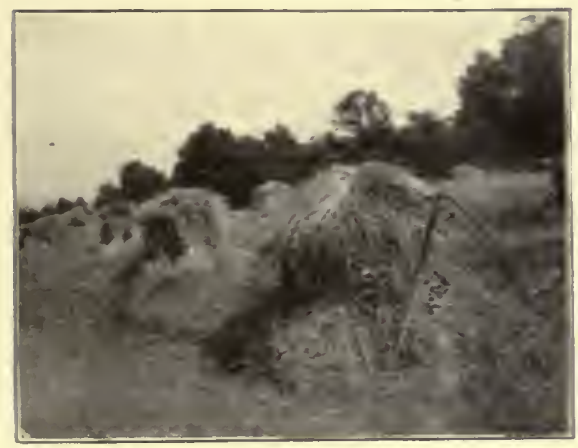

THE HARVEST. 


\section{THE PAPAW THICKET.}

"For thee the wild grape glistens

On sunny knoll and tree.

The slim papaya ripens

Its yellow fruit for thee."

-Bryant.

"Tall butternuts and hickories,

The papaw and persimmon trees.

The beech, the chestnut, and the oak."

-Madison Cawein.

"Wild plums and haws and berries, papaws, nuts, grapes, and all the fruits of unguarded nature, have something in them to feed originality."

-Maurice Thompson.

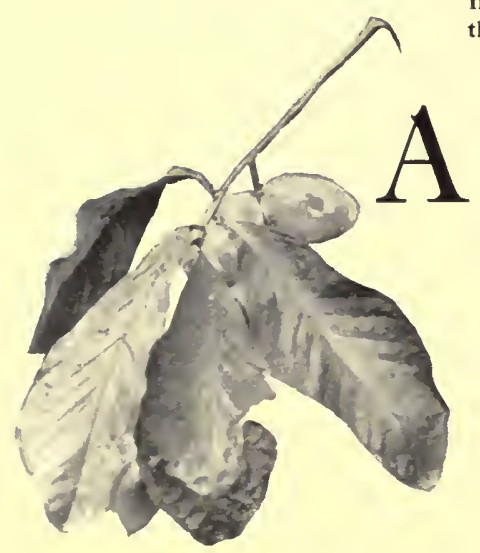

PAPAWS, WITH A SPRAY OF LEAVES.

GROUP of papaw-trees, with their long, broad leaves, colored yellow in the fall of the year, is one of the most beautiful and characteristic sights in autumn in the woods of our Central States. Doubtless to most Westerners it is quite familiar, but perhaps a few facts about our common papaw may be interesting to people living in the East, where it is altogether an unknown fruit, or to others who have never seen or tasted it.

Like the breadfruit and banana, the papaw, when very ripe, forms a natural, edible fruit which, although excessively sweet, is really quite palatable, and is very 


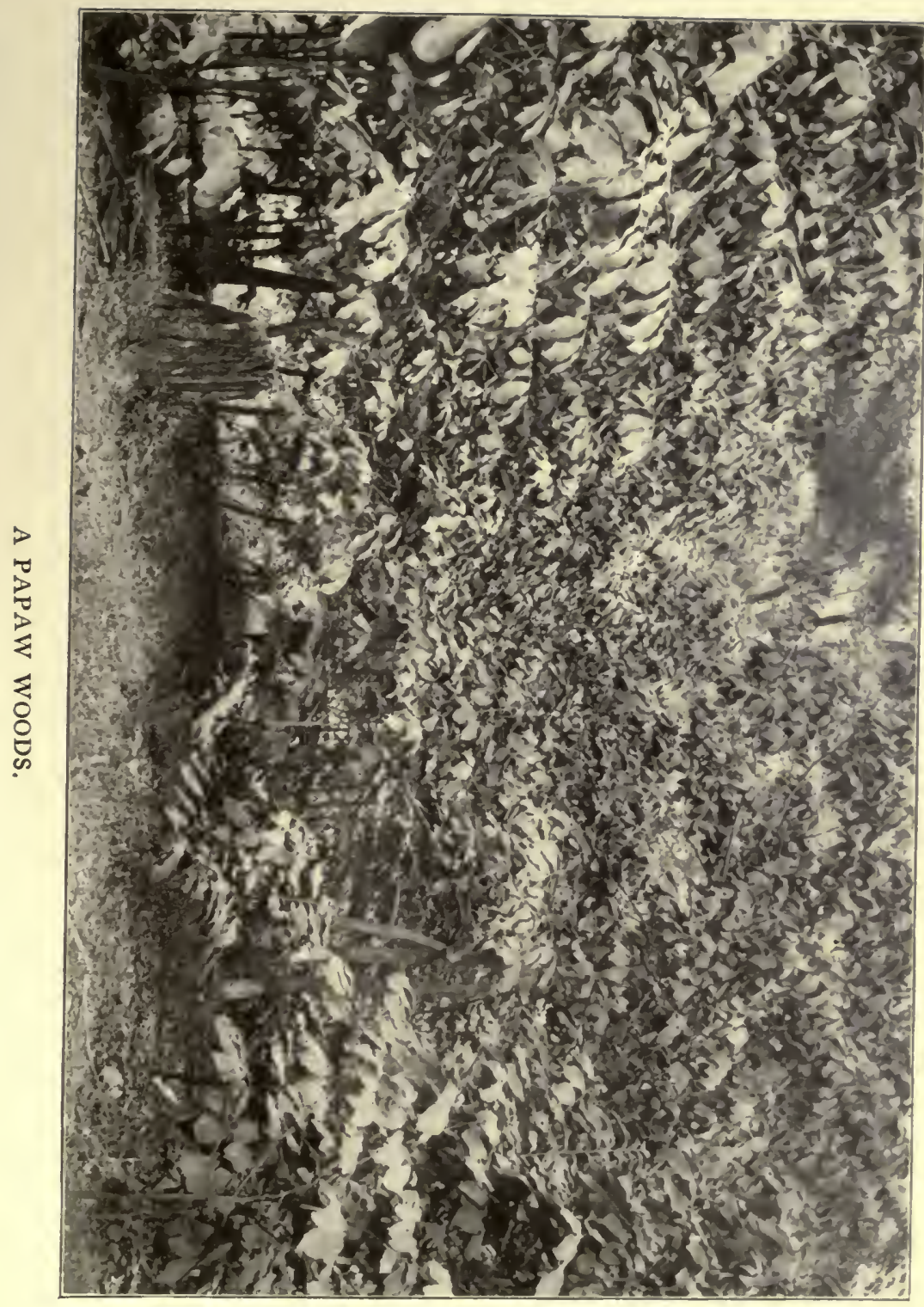



nutritious. Negroes and raccoons, and opossums especially, are exceedingly fond of them, and I have sometimes found the hair of gray squirrels on the branches, although I do not think that many animals eat them. Horses and cows will not touch them, nor, so far as I have observed, will hogs. I know of a dog, however, who will eat them greedily. Having observed his master at it one day, and having, as was right, a simple belief in the infallibility of his master's tastes and preferences, he, too, has thought it is good for food, and rolls his eyes, when he eats them, as if to express ineffable enjoyment.

The fruit, somewhat oval, is shaped like a short, bulky banana, generally smooth and symmetrical, but sometimes swelling a little irregularly, or slightly bumpy, or bulging out unevenly on the surface, and varying greatly in size, from mere nubbins no bigger than one's thumb to fine, large specimens that are often two inches thick and six inches long. They grow at the ends of thick peduncles, ${ }^{1}$ sometimes in clusters of four or five, but more often singly, or with but two or three in a clump together, these clusters, indeed, not infrequently thus resembling small bunches of bananas. ${ }^{2}$ They taste best and are richest when a little over-ripe, after a severe frost has turned their green skin to a mottled black and yellow; but, if picked just before frost, they ripen well in straw or bran. Every boy that has known of them has had his secret store of papaws

"These peduncles are often covered with rather thick short hairs, soft to the touch, but are more frequently to be found smooth and green.

${ }^{2}$ The odor of the banana and the papaw, too, is not unlike,-but what a difference in the seeds! 
ripening away somewhere in the mows, to be eaten with great gusto when the time arrived. Picked too green, however, they wither and decay, and do not mature; and to taste an unripe papaw

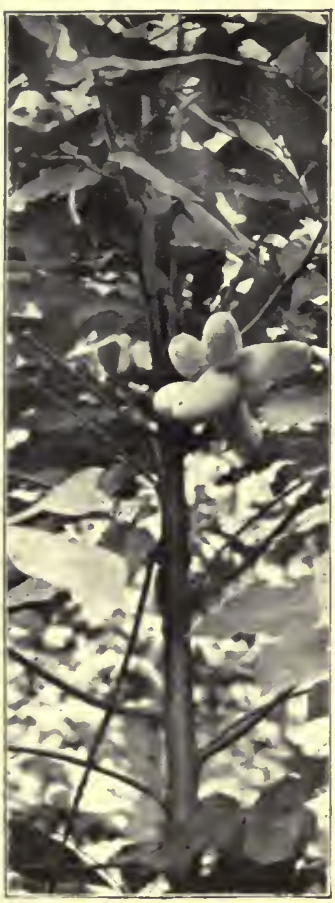

QUITE A CLUSTER! puckers the mouth as badly as does a green persimmon. Like most all fruit, papaws are exceedingly enjoyable if picked when ripe direct from the trees. There is then a fresh, delicious, creamy flavor which is a little lacking in those that ripen on the ground. The sweetish pulp is a golden orange-and-yellow, like custard; whence doubtless its other common name, the custard apple, which was, however, possibly suggested and appropriated from the original tropical fruit of the same name. The seeds, surrounded by pulp, and inclosed, like those of the date, in a membranous covering, are large and flat, sometimes bluntly triangular in form, but more often resembling those of the butter bean in size and shape, and are a glossy brownish black in color, as if varnished. Their shell is very hard, almost like horn. In their growth they are arranged at right angles to the ends of the papaw, in layers generally of two seeds to the layer, the number of seeds, of course, depending upon the size of the fruit, but ranging generally from two or three to as many as a dozen. These seeds can always be seen 
in numbers on the ground beneath the trees in the fall of the year.

Papaws have a taste something like that of a banana, or like a musk-melon, egg-plant, pumpkin, and squash combined, and yet with a distinct, musty, tangy flavor all their own. They are very fragrant, and a dish full of them will scent a whole house with a rich odor, as from an old wine cellar, like a bunch of arbutus in spring. The big, soft, mottled fellows are the best, and are really delicious. Indeed, I know of a distinguished journalist who is reported to have said that the banana simply is not to be compared in the same breath with the papaw.

Our papaw of the States, however, must not be confounded with the real custard apple of tropical America and the West Indies. The custard apple family botanically resembles the magnolia family, and all are tropical except the one genus of our common papaw. Of it, the leaves especially are much like those of a magnolia, though thinner. A papaw-tree, also, both in its leaves and in its slate-colored bark, frequently resembles at a distance a young hickory or sassafras sapling. The leaves are downy when young, but a smooth and shiny green when mature. Some of the papaw leaves are a foot or more in length, and are especially beautiful in their autumn yellow; fluttering in the breeze like streaming pennants, or slowly swaying like waving gonfalons,-or mayhap, as in emulation of the banderoles of a lance, drooping in full showy color from the twigs, like the feathers that hang from the lock of an Indian. The leaves, consequently, frequently overlap irregularly, one falling upon an- 
other's edge, like the scales of an inverted cone, the tips of the upper ones concealing the bases of the lower leaves, thus giving a peculiar sort of imbricated appearance to the foliage. The branches, ordinarily slender, spread upward evenly, when unhindered in the open, and shape themselves into characteristic pyramidal forms (the wigwams of the forest), though it is not uncommon to find them singularly distorted, with the main stems of the trees a trifle bow-shaped, as they reach across a streamlet. The wood is very soft and brittle, and hence practically worthless for commercial purposes, although, on account of its lightness, it is not to be despised if used for a cane or a staff, and many nice straight sticks of it can be found. The bark, however, though close to the wood, peels off easily, like that of the slippery elm, and is very tough and pliant; the inside layers, indeed, being so strong that, though they are apparently thin and tender, like raffia, yet, like it also, they can scarcely be broken by the hardest efforts. Boys therefore often make whips from long-drawn ribbons of the bark, ${ }^{1}$ farmers sometimes tie their broken harness together with thongs of it, and fishermen string their catch on strips and twisted strands of it $;^{2}$ for, if you cut in deeply at the base of a tall, smooth sapling, you can tear the bark off up to the very tips, and then, after removing the rough, gray outside, there will remain as strong and pliable a withe as one could wish. The

'“The bark," says Dr. W. C. Gray ("Musings by Camp-fire and Wayside," page 127), "makes famous whistles and especially fine whips. We used to make whips, the 'snap' of which could be heard a mile, and would echo like a rifle-shot."

'See Sargent's “'Silva," vol. I, page 24. 


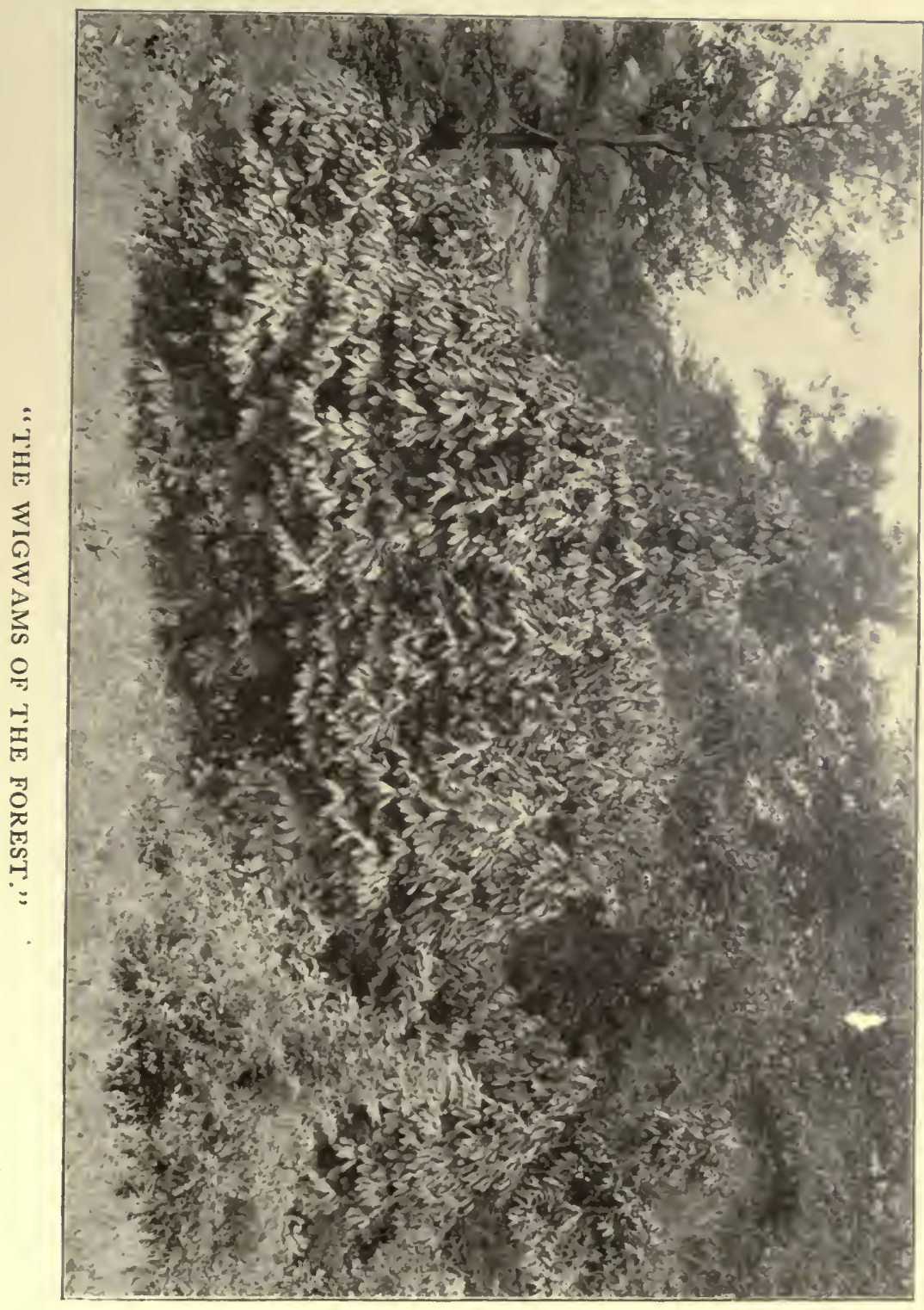



name papaw has variously been accredited to an Indian, Creole, or Malay origin, but is probably of the last. The botanical name of our Northern variety is A simina triloba ${ }^{1}$ the generic term being probably from the Algonquin, and meaning by derivation "sleeve fruit," from its shape, and the specific referring to the three-parted flower. There are also three other shrublike species whose fruit is scarcely so edible. In the United States the papaw is found from Western New York and Pennsylvania westward to Missouri, northward to Michigan (occasionally even in Ontario and Wisconsin), and southward to Texas and most of the Southern States. It is certainly one of the most attractive of the wild fruits of the woods, as it is also perhaps the largest of those native to the forest, and the name of "Northern banana" has been suggested for it. ${ }^{2}$

The axillary flowers, always solitary, precede or accompany the budding leaves in spring, blossoming out cup-like in some wild, shady spot in the woods, sometimes drooping and pendent, like a bell. They

${ }^{1}$ See the Century Dictionary, under "Asimina."

${ }^{2}$ Mr. Bradford Torrey relates the following, in a paper "On the Upper St. John's," in "A Florida Sketch-book" (page 126). He was carrying in his hand a sprig from one of the papaw shrubs of the region, just then in full bloom ("large, odd shaped, creamy-white, heavyscented blossoms"), when he met a negro.

"'What is this,' I asked. 'I dunno, sir.' 'Is n't it papaw?' 'No, sir, that ain't no papaw;' and then, as if he had just remembered something, he added, "That's dog banana.'"

I am inclined to think that some of those who depreciate our Northern variety might even appropriate, in derision, the negro's appellation to our own, although, as I have said, our papaw is ordinarily not much relished by dogs. 
are at first of a yellowish, greenish tinge, turning later to a dull, reddish purple or a rusty brown. A light frost easily shrivels them, and they wither and fall. A few, perhaps, secluded beneath some protecting branches, may survive the cold, but the papaws will be few and far between that year. These blossoms have sometimes a singular and slightly unpleasant odor to them, like that which comes from the leaves or bark also, when rubbed, pressed, or bruised, and similar to offensive ailantus; but unlike those of the smelling garden floridus) fre bloom, pleasantly, straw this
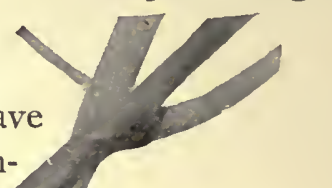
is it that teaches them this preference of their offspring? Can it be the memory of past experiences of their own, now become an intuition through the practice of long generations? And why should they like the papaw?

Papaw thickets are frequently to be seen in open clumps on hillsides, tut more often are concealed in secluded nooks in the woods; though they are seldom so secluded that some boy or other has not discovered their whereabouts, and I have generally found that others have been there besides myself. They will stand shade, and may sometimes be found growing beneath their larger forest brethren along the banks of woodland brooks; but I have noticed that they relish an open exposure to the sunlight also. The papaw-tree is ordinarily on the order and size of a shrub, but I have not seldom seen specimens fifteen or twenty feet in height, and well proportioned, with a trunk diameter of perhaps four inches. Sargent, in his "Silva," says they will sometimes have the diameter of a foot and reach a height of some thirty or forty feet. I am inclined to think that the trees bear a larger and better tasting fruit, and more of it, when comparatively young, in the form of a dense shrub, than they do when they have grown taller, though I have found good papaws on fair-sized trees.

There would seem to be, of Asimina triloba, really two kinds, an early papaw and a later variety. The fruit of the former is somewhat larger, and of a deep chrome yellow inside; and I have noticed that the leaves are a deeper green, and remain on the tree longer, and do not turn so soon; and the papaws on 
these trees will all be on the ground many days before those on the others. The late variety is smaller and more irregular in shape, and its pulp is a whitish cream color. The flavor of this later variety is perhaps a little more delicate than that of the earlier, which is coarser in fiber. Many of these later papaws will be hanging in clumps in October, and will still be hard and firm, while those of their earlier neighbors will all lie rotting on the ground. Yet the leaves turn sooner than those of the earlier variety, and frequently will be falling while the fruit is yet clinging to the twigs. These peculiarities may perhaps be partly accounted for by the situation of the individual trees, but I think not wholly so. I have noticed, however, that those in deep forest shade are usually of the earlier type, and retain their leaves the longest.

Papaw gathering is one of the delights of the autumn, and the eating of them one of the feasts of the year. I like to pick them, and to collect them from the ground, where they have been shaken off by the wind, or have fallen in their maturity. As I look at them, these long, pod-like shapes, ripening through the summer and autumn, I seem to feel a sort of primeval instinct coming upon me; I feel an intuition that these are unlike the other seed-vessels of the wild vines, and I say, " $\mathrm{Ha}$, man, here is something edible! You need no longer starve by the wayside."

The papaw prospers best in its wild state, in rich soil along the banks of woodland brooks, and the thickets are sometimes so crowded together as frequently to occupy the land almost to the exclusion of the seedlings of the other surrounding varieties of 
veterans that have protected these, their foster children. For some rcason the tree is seldom successfully transplanted; but the seeds, if planted in the fall, as Nature sows them, will sprout in a year, and soon thrive as strong and healthy little trees, although they require generally eight or ten years of sapling preparation before they begin to bear fruit. My greatgrandfather's woods, in southwestern Ohio (not far from the homestead), now cut down, at one time had so many papaw-trees in its underbrush that it was known everywhere as "the papaw woods." The clumps of papaw bushes in it used to.be so dense and the papaws themselves so numerous that bushel basketfuls have been gathered there, and wagons have been driven in to take them away, the ground being literally covered with the fallen fruit. I know, too, of more than one other woods that might well be called "the papaw woods," so dense in them are the thickets of papaw-trees, almost like groves of them, with the great greenish-yellow, esculent, fleshy, pod-like forms hanging in the air, or lying among the drifted leaves of their own parents, nibbled perchance by a rabbit or eaten into by insects.

The papaw in the early days was more of a feature of the woods than it is now, and the fruit was more generally eaten. I know of one singular old character who would gather a basketful of luscious papaws and then trudge twelve miles to the city with it to sell, along with some hickory nuts and walnuts, as his stock in trade; and he never had any trouble in getting rid of them. Papaws can still be seen for sale in the stalls of the Cincinnati markets in the fall of the year, and 
have their customers; for it is quite a cherished weakness in some people to like them.

The papaw, perhaps because of its puckery taste when green, is always connected in my mind with persimmons, although the persimmon comes later, and is best relished after Thanksgiving. I know of but one wild persimmon-tree in this township (though there are others in the county), but I will wager it has the true metal to it. I have come upon groves of wild persimmons in the woods of central Arkansas, where the trees are thirty feet high and over, whose fruit was nearly as large as a walnut, and as luscious and sweet as sugar. We would gather tree huckleberries with them, too, and a feast of these two wild fruits of the forest was a rare treat indeed as we ate our lunch at noon beside a brook.

Papaws are also associated to me with the finding of arrow-heads and the rising up of that spirit of roving and hunting which comes to us all at nutting-time. A papaw-tree, with its graceful yellow foliage, seems to me to be filled with the very spirit of the autumn woods. A woods without papaws lacks something, or, rather, would be more of a woods, would have more of the true forest flavor, if there were only an occasional clump of papaws on a ridgeside or in some picturesque dingle beside a brook. The scent of a gray squirrel or the whiff of a deer might then fill our nostrils, and the glimpse of a wigwam near the spring would only complete the papaw thicket's native wildness.

It is entertaining to read the accounts of the pioneer botanists in this country, and of their enthusiasm 
in the discovery and preservation of our trees and flowers. ${ }^{1}$ It was but natural that the papaw, being an unknown variety of the New World, should not escape them. "A jar of papaw flowers and fruit" (along with specimens and seeds of others of our trees, at that time quite rare and curious) was consequently sent over by John Bartram, the traveler, to Peter Collinson in England in 1738 (acknowledged in April, 1739), which is one of the first instances of any attempt at its introduction abroad; and Lord Petre's similar efforts, it is gratifying to know, met with great success, as appears from Collinson's later letters. Collinson was very inquisitive about the tree, and asked for all the details as to its flowers, fruit, foliage, growth, soil preferred, size of the tree, etc., that Bartram could give, to enable Lord Petre to identify it among his shrubs and plants, he having neglected to draw it when in Virginia, and relying solely for its propagation on the seeds; and, Collinson adds, in a postscript, "If it has any virtues, pray mention them:"-information which we fear, however, Bartram was never able to give,-for it has no virtues; it is only edible and beautiful." Theodore Mason Harris, too, in his "Journal of a Tour over the Alleghany Mountains into Ohio" (Boston, 1805 ; pages 61, 97), made in the spring of

'I am indebted to the Librarian of Congress for an extended bibliography on the papaw; in particular, I am under obligation to him for my references to Collinson, Bartram, Harris, Mr. Mather, and Miss Murfree.

${ }^{2}$ See William Darlington's "Memorials of John Bartram and Humphry Marshall," Philadelphia, 1849. Pages I00, III, I21, 128, 129, I45, 365. 
I 803 , mentions the papaw as growing in the greatest abundance, along with the dogwood and other kinds of trees, "on the sides of creeks, and near the river"just as it does to-day-and enumerates it among the wild fruit-trees of that region, with the cherry, mulberry, persimmon, and plum. Others, too, of the early explorers and students of our forests, like Michaux, have given their descriptions of the papaw. How interested they were in these discoveries and observations among the trees, and how eager we should have been also to find new varieties, and how delighted we are in these days when perchance we do!

Outside of the many books on trees, however (and even in the best of these the accounts are not very extended), the papaw has not found a conspicuous place in our literature. Dr. Gray places it among the trees that he loved in "This Paradise of Ours." Bryant speaks of "the slim papaya" ripening "its yellow fruit," and, since he puts it in company with the wild grape of the West, I have supposed that he means by it our common papaw. Mr. Madison Cawein also enumerates the papaw among the forest-trees of his native Kentucky, where it is, of course, quite common. Fosdick mentions the blossoms in a couplet.

There is one amusing passage which I must quote, in Mr. Fred Mather's humorous book of reminiscences, "Men I Have Fished With," in a chapter on "Fish, 'Coons, and Papaws" (pages 264, 265), which doubtless voices the sentiments of many who have tried to like the papaw, but who could never acquire the taste: 
"As the summer waned and the first chill days of September approached Frank asked me: 'Did you ever cat a papaw?'

"No; what is a papaw?'

"'They are a fine fruit, and grow on a small tree. They are shaped like a cucumber and are like custard. There is a papaw grove down by the river. They'll be ripe now in a few days, and we'll make up a party and go 'coon hunting. 'Coons like 'em, and you can always start one in the papaws when they 're ripe."

"I had seen the trees when out after wild plums, which were plenty in that part of Wisconsin, and were large and excellent, but the papaws were merely wondered at and passed. I think there were a dozen in our party when we started for 'coons on a moonlight night. Except Frank and Henry, Charley Guyon, John Clark, and Bill Patterson, the names are forgotten. Half a dozen dogs, some of no particular breed and others that seemed to be of all breeds mixed without regard to proportion, went along as a necessary part of the outfit.

"I tasted my first papaw, but have yet to taste the second. The others ate them with a relish. All I remember is that the fruit was shaped something like a banana, but shorter, and had the taste of a raw potato ground into a paste; its seeds were as large as a lima bean. Of course, I might learn to like them, but Potosi boys acquired the taste in infancy."

It is altogether likely that this "first papaw" of Mr. Mather's was one in the unripe, milky state, when it is decidedly unpleasant and disagreeable, or else he would hardly so have humiliated the noble fruit by characterizing the delicious pulp as "raw potato ground into a paste." His tree, too, was from one of those rare groves which have wandered as far north as Wisconsin, and the papaw never attains to a fine develop- 
ment or has much of a flavor farther north than the Central States or, at the outpost, Michigan, ${ }^{1}$ and is at its best in the fertile valleys along the Ohio.

It is refreshing to find at least one literary man who was a genuine worshiper at this wayside shrine. After speaking of the wild muscadine grapes of the South, the late Maurice Thompson remarks, in his "By-Ways and Bird-Notes" (pp. I oo, I I I):

"Next to the muscadine among wild fruit I rate the papaw as best. It is genuinely wild, rich, racy, and, to me, palatable and digestible. I once sent a box of papaws to a great Boston author, whose friendship I chanced to possess, and was much disappointed to learn that the musty odor of the fruit was very distasteful to him. He fancied that the papaws were rotten! I dare say he never tasted them; and if he had, their flavor would have been too rank and savage for his endurance."

Miss Murfree mentions the papaw in at least two instances in her stories of the Great Smoky Mountains. She places it with the laurel along the banks of the Solacutta River, in "In the Clouds" (page 64); and it was a pole trimmed there from a papaw-tree which Mink Lorey used as a lever to raise the mill gate with. In "The Despot of Broomsedge Cove," too (pages 9 and I2), she has a locust shrilling in a papaw-tree, and it was against a papaw-tree that Eli Strove, the constable, leaned as he sat upon a bowlder. These are, of course, simply incidental touches of local color

${ }^{1}$ The papaw, however, has for all time been immortalized in being perpetuated as the name of the Paw Paw River, of Michigan, and of some half-dozen municipalities called Pawpaw, in as many different States, one of which, in Michigan, has reached the dignity of becoming a county seat, with a population of nearly fifteen hundred inhabitants. 
which indicate the well-known character of that region in Tennessee, where papaw-trees abound.

In "The Little Shepherd of Kingdom Come" also (page 7), by Mr. John Fox, Jr., is this sentence, upon Chad and old Nance, showing that the papaw is in favor among the Cumberland Mountain folk as well as in the Great Smokies:

"With his Barlow knife, he swiftly stripped a bark string from a papaw bush near by, folded and tied his blanket, and was swinging the little pack to his shoulder, when the tinkle of a cow-bell came through the bushes, close at hand."

This glimpse of a picture of the cow feeding among the papaw bushes is, too, a familiar one to any one acquainted with our papaw-covered pastures.

But, other than these, and perhaps some few other chance references, the papaw does not seem greatly to have been celebrated in either song or story. Its really beautiful and flowing foliage, rippling away in its autumn yellow, with the fruit amidst the leaves, and the flowers and bark, have all indeed been too little appreciated.

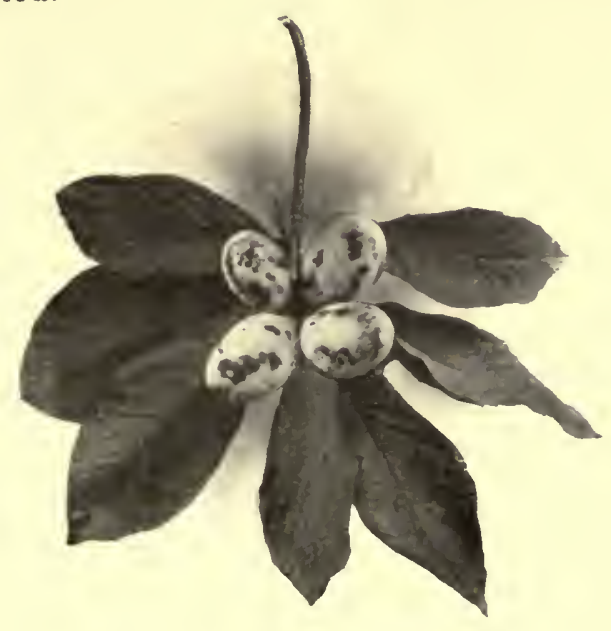




\title{
NATURE AND THE GITY.
}

\author{
"Now from the town, \\ Buried in smoke and sleep and noisome damps, \\ Oft let me wander o'er the dewy fields, \\ Where freshness breathes, and dash the trembling drops \\ From the bent bush, as through the verdant maze \\ Of sweetbriar hedges I pursue my walk; \\ Or taste the smell of dairy." \\ -Thomson.
}

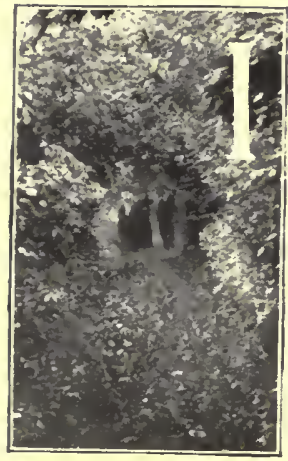

A COUNTRY LANE.

LIKE the cheery greeting one gets in the country. Every one always speaks to every one else, as if in acknowledgment of some world-old mark of blue blood that shines from the eyes of every human being. How different from the hasty, heartless nod of recognition one gets in cities, even from the best acquaintances! Democracy is greatness; most people are aristocrats.

Among country people we come into contact with simple, elementary impressions. They are, I think, happier than city people, more wholesomely happy. There is less attention paid to the whims of fastidious fashion, there is less conventional life, there is more freedom in the country than in the city. There is an essential directness and frankness of character and speech in all people who live in the country. The very outdoors itself, their nearness to Nature, their simplicity of life, and their self-reliance may make them so. Pure air and the best of food contribute to it. 


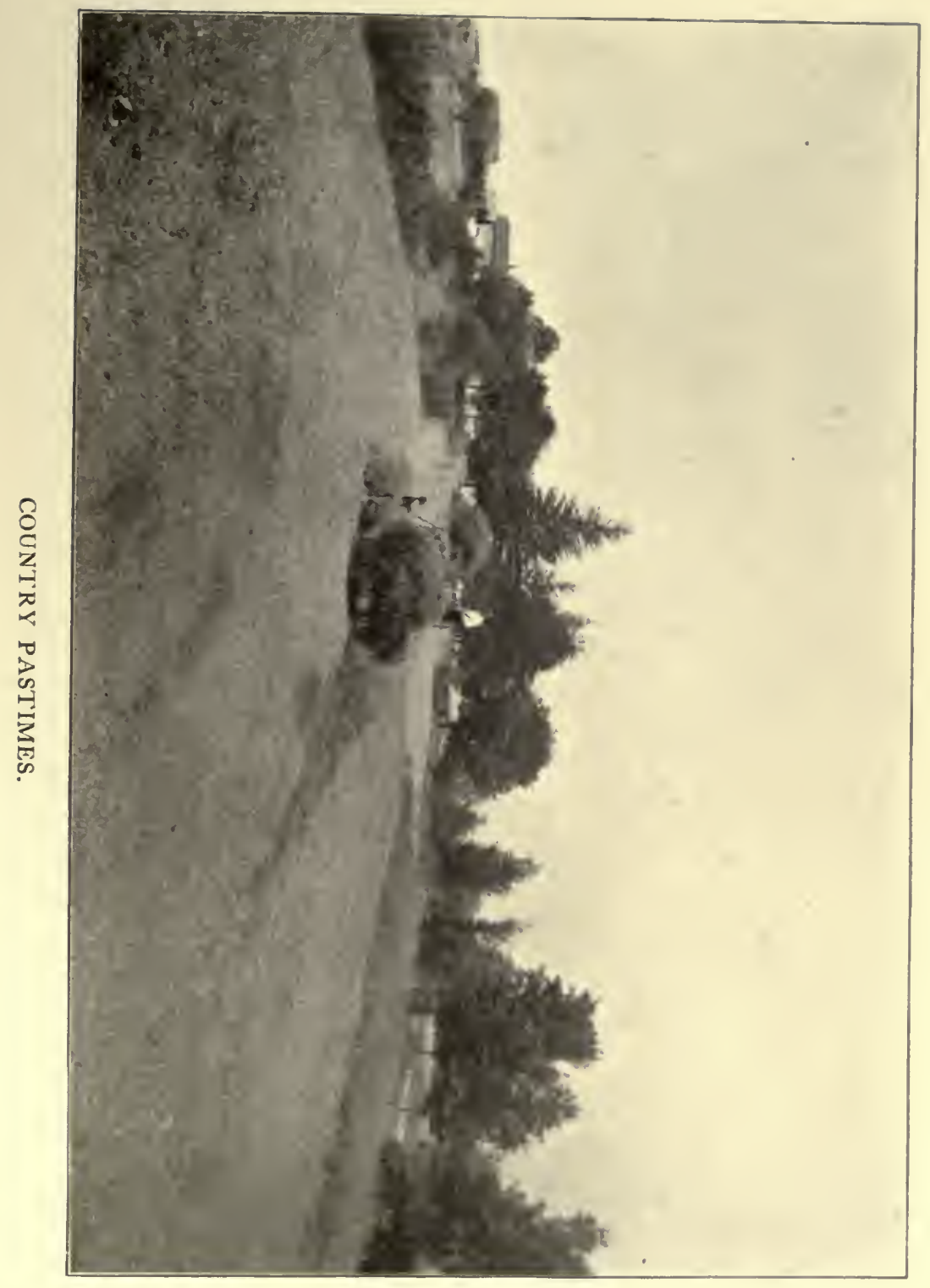



Most city people seem to be diametrically opposite. They do not know what the natural life is. Theirs is the artificial, conventional manner, and one who is unskillful enough to be ingenuous is not seldom considered a numskull. Yet the men of cities are much more effeminate and altogether less stalwart than their countrymen of the fields. Almost all the unhealthful life of cities is entirely lost out in the open, where life is pure and sweet, and the mind uncontaminated and natural. The farmer notices the wind and the signs of the weather. He is closer to Nature than most men, more dependent upon Nature. What city people, except the weather observer, ever know the direction of the wind, or can tell whether it is likely to rain or not?

There is a dignity in tilling God's soil which no other avocation in life possesses. Adam's original occupation was to care for the trees in the garden, "to dress it and to keep it;" but, after the fall, the first work that was given him, that which the Lord decided was then most fit, was the tilling of the ground and the tending of sheep, as if by these (even though in the sweat of his face he should eat bread, and should labor under the disadvantages of thorns and thistles to gain the herb of the field) so to keep his mind, as far as possible, from the baser and more ignoble sides of man's life, as it has now come to be. Little they knew in those days of the modern meaning of civilization. The Lord God, who placed him in the garden, is wise in His selections. Shall we not live likewise as $\mathrm{He}$ wished our forefather?

Farming and shepherding-these have been the life work of some of the noblest of mankind from the 
beginning. Tilling the soil was not the curse. The curse was the expulsion from the presence of God. And so, as if with the memory of thousands of years within him, farming - a means of livelihood, of some kind, in the open air-is not only the most primitive occupation known to man, but is the fundamental basis of procedure upon which all great business enterprises are conducted. The farm is the type in the study of political economy.

So that our poetic appreciations of Nature are perforce in time translated into terms of industry. The lover of the woods becomes a forester or lumberman; the lover of animals a shepherd, cattle raiser, stock breeder; the lover of open country life, such as Virgil depicts in his "Georgics," becomes the bee keeper, poultry raiser, fruit grower, and general cultivator of the soil for wheat and corn and garden produce.

We were made to work and to earn our bread, and the man or woman who does not labor, and work earnestly and with interest, is a parasite upon his fellows. Yet not only to work; but to enjoy our work and others' work, to have the satisfaction of some repose after work well done, the opportunity of studying and comparing life and the methods of life, and of reading the literature of other men's labors. We were made to work, but not to slave. Rest and quiet are as much a part of life as the work of the day, and almost as essential to the real spiritual return of the work as the toil is itself.

Yet does the farmer, when he turns the wheat over in his hand, look admiringly at the beautiful grains? Not a bit of it. He is scrutinizing them to see whether 
the wheat is well threshed, is full-bodied or thin; in short, whether it will sell well. Farmers, as a rule, are too literal disciples of Emerson in their philosophy of the beautiful. The beautiful to them is too frequently the useful. Beautiful fields! Why? Because they will raise good crops of wheat. I am reminded, in this connection, of a quaint and characteristic anecdote by Thoreau in his journal ("Autumn," October 7, 1860) :

"Remarking to old Mr. - the other day on the abundance of apples, 'Yes,' says he, 'and fair as dollars, too.' That 's the kind of beauty they see in apples."

Poetry vanishes somewhat when we make money out of Nature; and farming, followed solely as a scheme for riches, has as much as any other occupation a tendency to make men sordid. Yet even as a business it is the nicest of any, and is the most largely practiced; and the reason it is not often more remunerative is that the farmers themselves do not always use good sense. But as a pleasure it is always a profitable pastime.

It takes considerable intelligence to manage a farm well, and the old supposition that any body can farm is as baseless in reasoning as it is without foundation in fact. The increasing number and importance of our agricultural courses in higher and more elementary education is the strongest possible testimony to the large part which the successful cultivation of the soil holds in our national life.

I remember telling an old farmer once how a man whom I had visited was feeding his pigs with soap- 
suds. "Well, sir," said the old gentleman, "there jest ain't no use in talkin'; soapsuds hain't no 'count for hogs." Now there was a farmer who had some intelligence. And he practiced what he preached; for his pigs, as I happen to know, always had the best of milk and corn, and plenty of it.

It is from such surroundings that some of the greatest poets and writers upon Nature have sprungBurns, Jefferies, Whitman, Thoreau, Flagg, Burroughs -and they have not infrequently remained farmers. Our great statesmen and Presidents have, as a rule, been brought up on farms. It was there they learned self-reliance and independence, and laid the foundation for all their future careers; and it has been to the country that they have returned to pass their declining years. President Arthur is the one notable exception among our Presidents of one who was born and bred in the city. It is as if, in the old myth of Antxus, a touch of Mother Earth adds strength to character, and furnishes a never-failing source of vigor and manliness.

The farm is the best place on earth in. which to bring up the boy. Mr. Murat Halstead, whose early years were passed not far from the homestead, has spoken of his final relinquishment of the life of a farm boy, even though journalism brought greater success, with genuine feeling:

"I have never since walked between plow handles, the more's the pity, it sometimes seems, for the nlow carves a path of independence that should be more highly considered than it is as a walk of life."

Cobbett's "Rural Rides" reveal the unmistakable charm of the outdoors to one whose life was spent 
largely in cities. Yet Cobbett lived when young in the country; and that is the only way, after all, to learn to love Nature-to become familiar with her in one's childhood. "Youth is the only season for enjoyment," says George Borrow (that genuine lover of the country), in "The Romany Rye," "and the first twenty-five years of one's life are worth all the rest of the longest life of man." Do you remember how Jefferies, when forced to live in London, longed for the country? A recent American writer, too, Mr. Charles M. Skinner, in his "Nature in a City Yard," laments that he is forced to live in the city. "I would live in the country," he says, "but I am compelled to live in the city."

The great men of the world have, with but rare exceptions, always loved the country. Most of the permanent and beautiful literature in every language is upon Nature and the country life. These are the masterpieces that live. The Bible is full of outdoors; Homer and Virgil would be nothing but a babble about the gods were it no: for their perennial inspiration from the things of earth and sky (and these, the phenomena of creation, change not, nor our poetic appreciation of them, in all the centuries); Dante is nearly as replete with natural comparisons as are the Greeks and Romans; Shakespeare uses Nature as a background for his human drama.

Do you recollect this saying in the recently discovered "Logia" of Jesus?

"Raise the stone and there thou shalt find Me; cleave the wood and there I am."

Well, the man of the cities has never felt that, for he has never known that particular phase of life. 
Every experience in Nature is worth something. I like to observe the methods of Nature, and to follow them in my farming. Nature is a great teacher. She invites us to her complicity, to be in league with her. If we take an exotic and bring it to our country, we shall have to study artificial surroundings for it, and not leave it to the ways of Nature here; but in the case of native plants and trees we shall find it best to leave them to Nature's keeping, or at least to prune and protect them according to Nature's evident intentions. It is from Nature that we learn to mulch our shrubs and berries, and the value of leaf litter for soil enrichment; for the wind blows the falling leaves of autumn everywhither, till they lodge about the thorns or the lower network of the shrub, caught by design in the thicket for its wintry protection, or are left to strew the forest floor for future generations, or to stray to the outlying fields beyond.

I can not sympathize with that view of life which would sell the old homesteads or see old landmarks brought low. It is only the materialistic spirit which will drive surveyors' stakes through a woods. The country is God's home. Why not ours? Yet men, in their impertinence, must needs have luxurious living; and exist, as it were, apart from Nature, separate from it, not enjoying it. But the old nomadic life is the most natural, after all, like the gypsies', with the stars above and a bed of greensward. I envied that gypsy queen I read of who had never yet slept under a roof, and who said she would feel unnatural and smothered to be deprived of the sight of the stars from her pillow. Hosea, the Hebrew prophet, gave a picture of the 
effects of too great ease upon the men of his generation.

The mediæval ideal still lingers amongst us. We are afraid of Nature. I suppose there are still people who would not care to study the trees and flowers except conventionally, in a city park, and who certainly would not remain long in a woods for fear of some intangible sort of lurking danger. But there is nothing to be afraid of in Nature. The ordinary snake is as much afraid of you as you are of him. Yet many city people seem to have really a shrinking fear of Nature and the country. I have seen little boys cry in terror when taken away from the road on a stroll to the fields or woods. A friend of mine, quite an intelligent man upon other matters, was openly much disgusted when I told him one day that I was going to the country with a book, and that I liked to lie among the grasses and read there and think, and sometimes slept beneath the trees. "Why," said he, "you 're crazy; you 'll get bugs and worms in your ears." Yet none ever bothered me, but were rather, what few there were of them, a very interesting study in their curious, beautifully colored forms and evident intelligence; and those that by mishap did crawl upon me scuttled off in short order when they found where they were.

But, of course, to be in the woods much is to appreciate wild life all the more. Then the whole world of Nature seems thoroughly remote from man's dominion. And everything in Nature is wild. Even the little weed that grows up between the planks of the city street is wild, distinct, different from the city, so separate in its life from man's life, so suggestive of the 
woods and fields and the far-away forest life, whence it sprang.

What is a city? A city is an assemblage of houses close together, with bad air in between them and similar lives inside of them. I ought perhaps to add that the lives are not always so bad as the air. But here is nothing but rows of brick houses, dirty children playing in dirty streets, dust, smoke, grime, soot. Where are the flowers, and where is the grass? As I have gone down into the city from the hills on foggy mornings, it has seemed as if I were entering into the very darkness of Dante's "Inferno" — down, down!-smoke, smoke everywhere; dense indistinctness; the horrible smells of slaughter-house and brewery; vapors of what not issuing from every alley; lights seen dimly glimmering through the murky atmosphere; cries and noise and the rumbling sound of innumerable wheels-surely, this is a part of Hades!

What a picture, that of a city, in Carlyle's "Sartor Resartus!" Teufelsdröckh is speaking, viewing from his watch-tower the great community about him:

"I look down into all that wasp-nest or bee-hive, and witness their wax-laying and honey-making, and poison-brewing, and choking by sulphur. . . . That living flood, pouring through these streets, of all qualities and ages, knowest thou whence it is coming, whither it is going? . . . These fringes of lamp-light, struggling up through smoke and thousand-fold exhalation, some fathoms into the ancient reign of Night, what thinks Boötes of them, as he leads his Hunting Dogs over the Zenith, in their leash of sidereal fire? That stifled hum of Midnight, when Traffic has lain down to rest; 


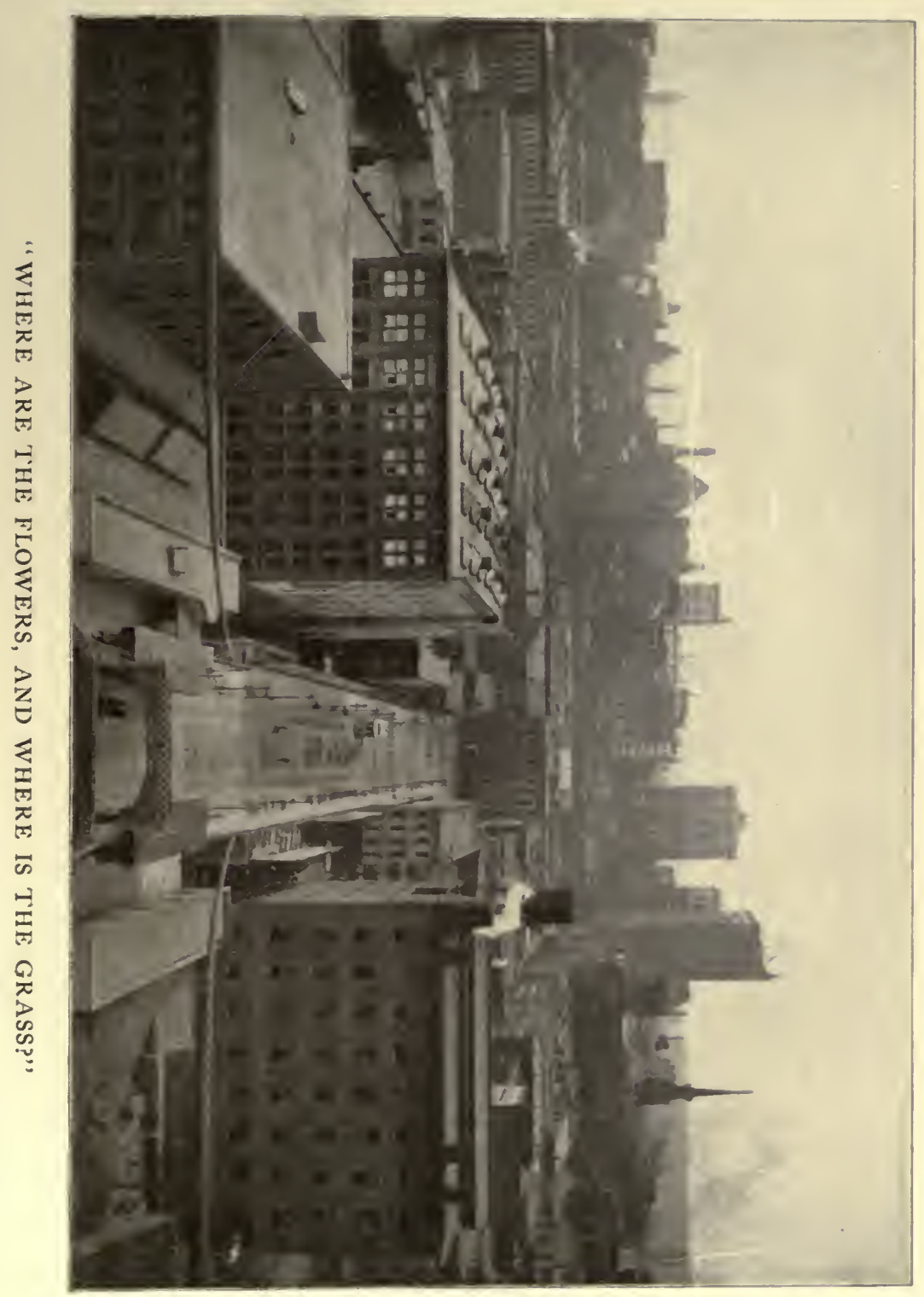



and the chariot-wheels of Vanity, still rolling here and there through distant streets, are bearing her to Halls roofed in, and lighted to the due pitch for her; and only Vice and Misery are abroad: that hum, I say, like the stertorous, unquiet slumber of sick Life, is heard in Heaven. Oh, under that hideous coverlet of vapors, and putrefactions, and unimaginable gases, what a Fermenting-vat lies simmering and hid! The joyful and the sorrowful are there; men are dying there, men are being born: men are praying, - on the other side of a brick partition, men are cursing; and around them all is the vast, void Night."

Readers of Richard Jefferies will remember the terrible experience that Felix underwent in his unintended journey toward the imaginary extinct city of London; how he found that all life had disappeared in the limits of its site, that gloom and dense vapor surrounded everything, that the atmosphere suffocated with its loathsome gases whatever living creature might helplessly stray thither, that the stars could not be seen because of the lurid, impenetrable canopy of smoke; and the joy, too, with which, after his canoe had drifted onward and through and past the miasma, he awoke from his stupor, powerless and tottering from the effects of the stagnation, and heard a thrush, and listened to the moorhens and whitethroats again, and watched the swallows tracing their beautiful curves in the pure air, and at last once more lay stretched upon the grass. Well, is that not an allegory of the influence of the city upon the natural life of man? The story of "After London" is perhaps not so imaginative, after all, but is rather the symbolic presentation of a pro- 
found spiritual truth. The city is indeed a great dismal miasma. Fear, distrust, disease, evil, pride-these, and many things more, alas! I find in the country; but I do not find them so intense, or so evident, or so plentifully abundant, or so openly pleasurable, as in the city. Pale, sallow complexions, bad food, physical languishment, spiritual stagnation,- - fresh skin, with a peach bloom to it, pure food, health, and a free, clear life of the soul:-look upon this picture, and then on this! Ah, Whittier was right when he sang:

\footnotetext{
"Blessings on thee, little man, Barefoot boy, with cheeks of tan!

Outward sunshine, inward joy;

Blessings on thee, barefoot boy !"
}

Why is it that people will congregate into such tremendous settlements as some of our cities are? The whirl of the world and the energy of our American life have made our cities absolute hydras of society. I think of Bryant's phrase- "the vast and helpless city." To many city people the word country is a symbol for the wild and desolate, the unhuman, everything that is devoid of sympathetic companionship; and so men gather into cities, for the satisfaction of an increased social life and the nearness of human kind. Yet Thoreau was perhaps right in his cynicism upon the shallowness of much of it. "What men call social virtues, good fellowship," he says, "is commonly nothing but the virtue of pigs in a litter to keep each other warm." And the Duke was also right, when he said, of the country, in "As You Like It:" 
"And this our life, exempt from public haunt, Finds tongues in trees, books in the running brooks, Sermons in stones, and good in everything."

One can not say the same for the city. The beautiful influences of Nature are to be received quite "far from the madding crowd's ignoble strife."

What a fine thing it is to have violets around you at your work! Was it William Morris who said that it was a sad contrast between the fields where the beasts live and the cities where men live? Cowper, indeed, spoke the truth, in his well-known line:

"God made the country, and man made the town."

I can sympathize with Christ when $\mathrm{He}$ wept over Jerusalem; but I can not follow Him into the city. It is not for every one to follow Him into the city. Some there are whose greatest joy and service is to live among the slums, and there to show forth the life of Nazareth. I will rather live apart, outside the limits, that so by telling of the sky and the green grass and the trees I may perhaps bring the vision home to those who see it not.

There are, of course, advantages which one finds in a city and not in the country; but it is not because it is the city that one finds them in. There is no reason why there should not be in the country all the advantages that cities have, and more. Most country people look upon cities as a veritable Mecca of all that is desirable, an El Dorado of gigantic proportions, in which one is caught into the whirl of all the social and intellectual life of the world. Yet good schools abound outside the cities nowadays, and it is possible to have 
art in the country, and music, and the literature which is the boast of cities, and to live, moreover, surrounded with all the perpetual beauty of sky and earth, with pure air and pure food and sweet, clear water, with opportunities for refreshing labor and for companionship with the animals and with all the life of God's world. Art museums might just as well flourish out in the open air, amid the scenes which inspired their paintings, as in the smoke of factories; and culture ought no less to be advocated and pursued in the fields than in the paved streets. Indeed, the pictures in the galleries do but afford a glimpse of that which lies on every hand beyond their walls. The dangers of life in the country lie in the sordidness which is found in many farmers, and which absence from the refining social influences of the city encourages. Then, too, when farming becomes too absorbingly a business its poetry is lost. But its decided advantages are the independence and self-reliance it develops; and he would be a thick-skinned fellow who did not see some poetry in his fields of wheat. And the power to do good, too, lies with the countryman; for were it not for the farmer men could not live. Yet women especially (and not altogether without reason, as many farms are managed) regard life in the country, on a farm, as they would life-imprisonment, as an existence absolutely devoid of any pleasure, or beauty, or society-nothing but a routine of perpetual drudgery: anything but that, they say. Yet are the social advantages of cities so absorbing as all that? Could not a little mite of them be introduced into the country? Many women there be after the order of Mrs. Hardcastle, in "She Stoops 
to Conquer," who says to Hastings, in reply to his flattery:

"We country persons can have no manner at all. I'm in love with the town, and that serves to raise me above some of our neighboring rustics."

Yet is there not a charm in an informal gathering in the country, where old songs are sung, and old poems read, and anecdotes brought forward of old times and former days, with a taste, perchance, of honey or of cider, which one will seek for in vain in the city? When Mrs. Hardcastle objects to her old-fashioned mansion and her husband's predilections for old stories, and says that she hates such trumpery, Mr. Hardcastle doughtily replies, and well:

"And I love it. I love everything that's old: old friends, old times, old manners, old books, old wine; and, I believe, Dorothy (taking her hand), you 'll own, I've been pretty fond of an old wife."

One of the most refined and cultivated, and yet hardest working, women I have known, and one who has lived in a city, once said to me: "When I see the life in the cities, I am always thankful that I have had the opportunity to bring my children up in the country." It was the wish of the poet Coleridge that his boy Hartley should be "Nature's playmate," and he so expresses this desire in his "Frost at Midnight," in these lines; and it is a satisfaction to know that, with all his weaknesses, Hartley retained a love for Nature all his life: 
"My babe so beautiful! it thrills my heart With tender gladness, thus to look at thee, And think that thou shalt learn far other lore And in far other scenes! For I was reared In the great city, pent 'mid cloisters dim, And saw naught lovely but the sky and stars. But thou, my babe! shalt wander like a breeze By lakes and sandy shores, beneath the crags Of ancient mountains, and beneath the clouds, Which image in their bulk both lakes and shores And mountain crags. So shalt thou see and hear The lovely shapes and sounds intelligible Of that eternal language which thy God Utters, who from eternity doth teach Himself in all, and all things in himself. Great universal Teacher! he shall mold Thy spirit, and by giving make it ask.'

Things that are really quite expensive luxurics in the city-genuine, rich cream, for example-are commonly every-day affairs in the country. Any one who has eaten strawberries from a cut-glass dish in the city, even with the best of cream, and then at another time has plucked them himself from the vines, fresh and sweet and juicy, and had the cream and sugar of the country with them, will not hesitate to say which is the more delightful, which the more natural to the taste. Even in a railroad dining car, when skimming across the country meadows, I have eaten corn on the cob which, notwithstanding its silver handles, many a farmer would have been ashamed to have on his table, much less to offer to a guest.

What a long succession of pleasurable delicacies is to be had in the country throughout the year: beginning with maple syrup and sugar, then the garden and the early strawberries and raspberries, wild blackberries, 
cherries, peaches, apricots, the early apples, plums, pears, the fall and winter apples-and all still lapping over from one season to another, the maple syrup often doing duty even in winter, a year from its making, along with the berries of last summer and the apples of the fall. There have been known such prosperous years on the old homestead that the old promise to Israel seemed to have been fulfilled especially for us, that the "threshing shall reach into the vintage, and the vintage shall reach into the sowing time." On those memorable, happy years, the last run of the sap at sugar-making would lap over on to the spring plowing and the pruning, the early vegetables would still be palatable when the later garden was well under way, haying and harvest would extend until the apples were ripe, threshing would occupy us up to cider-making, and the corn husking and hauling in of the winter wood and the other fall work would keep us busy until the hogs were fattened-and by that time the sap was in the trees again and the camp opened. But they have not all been such years; for sometimes the sugar season was a short one, frost nipped the fruit buds, rain spoiled the hay and flattened the grain, worms and insects got in the garden patch, wasps stung the grapes, and somehow the winter wood was water-soaked and doty.

In many city yards, cut up for a subdivision, last remnants of the country still linger where not disturbed. An occasional stray violet may yet stay to bloom by the wayside, golden-rod and iron weed shake their tassels in a fence-corner, or a clump of elderberry bushes hold aloft their glistening cymes of jet black berries. But, when pent-up perforce for a time between 
brick rows and asphalt, my heart has always longed for a sight of God's meadows and the open sunshine among the grass.

My instincts for wild life are so strong that had I been a primitive man I imagine I would have helped the race along considerably. I like to walk through the parks whenever I am in cities, for the waving of the trees' leafy branches in the breeze brings thoughts of the wide, sweet freedom of the country beyond. Especially is the dark mystery of trees to be felt in a city in the gloom of night, even though the trees are surrounded by wire railings and their poor roots suffocated under hot pavements.

\footnotetext{
"But this you may know, that as long as they grow,

Whatever change may be,

You never can teach either oak or beech

To be aught but a greenwood tree."
}

There is much truth to those lines of Peacock's. There is always a little of primitive, natural grace, with a smack of pure wildness to it, still to be seen, even in city parks. Such experiences as this in Shelley's "Epipsychidion" are perhaps not common now to dwellers in cities, but are none the less enviable:

\footnotetext{
"The spotted deer bask in the fresh moon-light Before our gate, and the slow, silent night Is measured by the pants of their calm sleep."
}

Lines like these, we say, thrill us in the reading, and we lament the departure of the old wild forest life. But, happily, if we scek it, something of that fresh life of Nature can yet be seen in the busy cities, atrophied and bloodless as life is there, life that was once so true 
and pure in the youth of the world, and that still is throbbing and swelling with the old savage strain beneath. The glimpse of a gray squirrel in a park, late on some afternoon, frisking and leaping among the beeches, even though he be tame and not afraid of the hoof-beats of horses and the rough tramp of heels on the walks, or the sight of the first birds of spring, or to hear a robin's twilight carol, still has power to make the heart rise in wonder, and even now, as Emerson sang it,

\section{"Can make the wild blood start In its mystic springs."}

In winter, too, the snow falls on the city streets as well as on the fields, and in spring the sweet country wild flowers can be found in the market stalls by those who wish for them.

Yet it does men incalculable spiritual harm to remain so close to one another as our cities demand. Let us at least walk out to the roadsides and the woods occasionally, and refresh and purify our minds in the quietness and joy of the beautiful world. While down in man's crowded dwelling-places all is excitement and intensity and unnaturally forgetful, out in the open the wind is tossing the tree-tops and sweeping to us odors and scents of green meadows and quiet wood-dingles, of lake and river, of prairie and forest, of sea and mountain, and of the broad life and health of Nature everywhere. Men in cities should listen to its voice whispering among the leaves. It brings the message of peace to them.

As I think of the contrast between it and these distant green upland pastures, quiet, grazed on by sheep, 
with bells tinkling, the city seems to be a horrible maelstrom. Why is it that men should live thus, aroused to an abnormal energy, and enveloped in great clouds of smoke and dust? Sometimes, when a south wind strikes the city, there comes floating out across the hills what appears to be a dark fog. It is the smoke from the city. Viewed in our clear, pure air, it is seen in its real density and murky blackness, as if just belched from the pit. Yet in the city it is the normal atmosphere which men breathe, and they do not know it. And so we turn from the sordid, restless, nervous life of the great city to the calm and beautiful quietness of the fields; and we have found peace, and are ashamed that we have known the city.

The tinkling of sheep bells, the bark of a dog, the neigh of a horse, the moo of a cow, the crowing of old chanticleer-why, morning in the country is the "Pastoral Symphony" in daily repetition. Do you remember how the sounds of the country are so pleasingly and wonderfully reproduced in that piece of music?

Give me the country, with an open hearth, and you can have an entire city in exchange, with all the intricate and over-studied refinements and complexities in it, and you will not be half so happy. I can, here in the country, before an open wood fire, with but one or two utensils, and with vegetables and fruit fresh from the garden, prepare in a few moments a meal fit for the gods: you, at your hotel or luxurious residence (and surely not in a hovel), will not have one a whit better, and you will have paid a dozen prices for it, and the china and the service will have cost you no little. Men go to the cities to escape the so-called 
drudgery of living; but behold! they find themselves enmeshed in a much greater entanglement than they had suspected, and some get still further ensnared into failure. They miss the very freedom and relief which they had hoped to find, and end by losing what fine old natural instincts they had, so that their last state is much worse than the first. Men pay pretty dearly for their refinements, in the loss of that for which, after all, the refinements are, and can be, no substitute. And so, because of the limitations of each kind of life, we have the strange spectacle of country people aping the ways of city people, and losing the very simplicity they were supposed to have, and city people constantly reverting to the country to find it. ' $T$ is the old story of Maud Muller and the Judge which is daily enacted before our eyes.

I do not say what is the remedy for all this. Each one of us most solve that for himself. We are not necessarily clumsy ignoramuses because we live in the country, nor are we all conventionalized hypocrites whose lot has fallen in the city. But decentralization, and the gradual increase of a semi-rural population, made possible by the introduction of the trolley car, with its cheap fares, must by every one be regarded as a force for good, and for good only.

Yet I would voluntarily narrow my life if I might only know more of Nature. I can not tell you with what feelings I regard Nature, I regard her so sacredly. I wish that others could enter into my life, and see the beauty. I would share the loveliness of the earth. It is not mine only, but all may see it, if they enter the fields with receptive mind and heart, equally with 
the open air. And all is so exquisite in workmanship, so wonderful in its growth, so beautiful in its drapery! Surely here in the stillness God is, if $\mathrm{He}$ is anywhere on earth. Men can not understand the miracles of Christ, they say, and yet are they dead to the constantly recurring miracles of sunrise and sunset, and spring and autumn, and the growth of the year; but then, that is every day, and they do not see the miracle. There is so much variety in Nature, so much profusion of beautiful scenery-grand contours of mountain wildness, illimitable extent of prairie, long, winding sea coasts, quiet slopes and dells, stretches of peaceful woodland:-carpeted with flowers and grasses, covered with towering trees of living green, an endless harmony of color, with the blue sky above, fleecy clouds, the broad light of day, and the majesty and silence of night and the dew! What can we say?

Thus to be surrounded with all the influences of Nature, the fresh wild flowers in spring, the great blue sky in summer, the turning leaves in autumn, and in winter the snow; to live in daily communion with the growing earth; to see the seasons change; and to be in constant response to the beauty and miracle of wild Nature:-if there is anything more to be desired in life than this I do not know it. Just the joy of living in the open air-that is enough in life.

Mr. Norman Gale has written a prayer, to be found in his "Orchard Songs," which, in its aspiration, exhales the very breath from the grass and the dew. Doubtless it languages the attitude of every lover of the country: 
"Tend me my birds, and bring again

The brotherhood of woodland life,

So shall I wear the seasons round,

A friend to need, a foe to strife.

"Keep me my heritage of lawn, And grant me, Father, till I die,

The fine sincerity of light

And luxury of open sky.

"So, learning always, may I find

My heaven around me everywhere,

And go in hope from this to Thee,

The pupil of Thy country air."

It was the fond belief of Richard Jefferies that some day Nature should have perpetual, constant influence upon the life of man, that man's life should always be becoming like Nature's. The sooner men learn to love the simplicities of the country the healthier will their own lives become, and the better and more wholesome influence, therefore, will they themselves have in the world. In turning from the distraction of a life of artificial stimulus to the revelation of the fields, what do we find, says Jefferies? "To be beautiful and to be calm, without mental fear, is the ideal of Nature."

So, in the city, I live over again the old life of the fields, wandering among the pastures, and by the side of clear, rippling brooks, and under the beeches. And in the dust and rumble and whirl of the city I can remember the ideals of life that I found out there, among the mullein stalks and sweet green grass, and I can live better for them, and can try to have Nature transformed into my human life. Like Jefferies, I may 
never realize the ideal that I found there; but I can approach it, and I can tell others that it is there.

It is as David, the psalmist of Israel, sang centuries ago:

"Yea, the sparrow hath found an house, and the swallow a nest for herself, where she may lay her young, even thine altars, O Lord of hosts."

And from those altars rises under the sun the incense of the flowers and fields into the beautiful blue.

"THE LORD IS IN HIS HOLY TEMPLE;

LET ALL THE EARTH KEEP SILENCE BEFORE HIM."

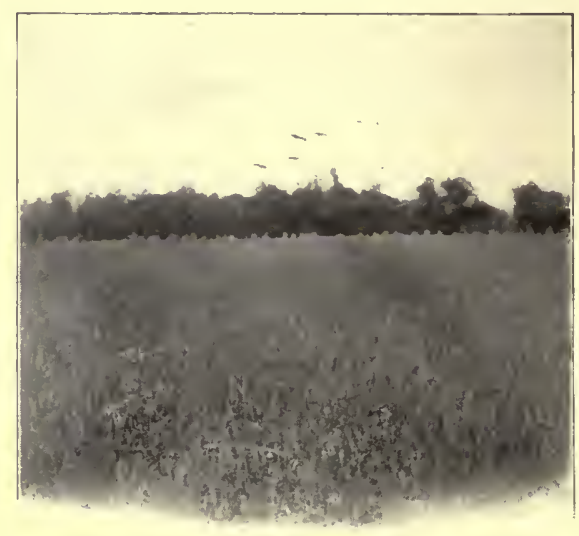

UNDER THE BLUE. 


\title{
NATURE AND THE PROBLEM OF SUFFERING.
}

\author{
"Thou see'st, we are not all alone unhappy; \\ This wide and universal theater \\ Presents more woeful pageants than the scene
}

Wherein we play in."

-As You Like it.

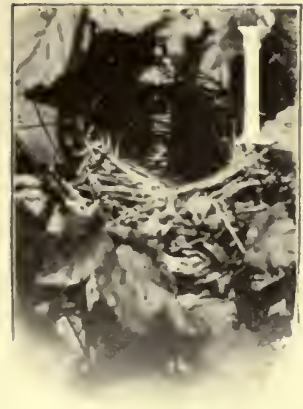

A plundered nest.

$\mathrm{N}$ assuming that pain is an evidence of evil which, while in a less degree it is forced to serve as a good, yet in its more terrible aspects attains at times to the deeps of unrelenting tragedy, I am taking a view which is not uncommon nor irrational, and which will, I think, be acknowledged as a fact in life by every one. What shall we say of King Lear, if tragedy be not a reality, but only a disguise, a mask? I believe that evil is evil, that it mars life, till it is not as it should be or was meant to be, that it is not a good, and can not be. Nor does evil come merely from the fact of our being finite beings. Adam and Eve were created finite, and yet were supremely happy in the Garden. We all know the old story of the clown at the games, who, when a pigeon was pierced and fell, said, "Ah, you might have spared the arrow! The fall would have killed him." So, to say that pain serves ultimately to bring about good is but a relative, a partial view; we might have had the good without 
the pain. For not all pain brings with it joy, nor is all joy derived from pain. The thrusts of tragedy are not necessary to happiness.

The world, that is, is diseased, and its natural intentions perverted and distorted. "The time is out of joint," as Hamlet said. It is a fact which does not need much repetition to gain acceptance. The apostle was not so far wrong when he insisted upon our depravity. Humanity has had its golden age in the past, and looks forward to another golden age in the future. We have not been made glad that sin has entered into the world. We might have lived without the sinelse why the vision of the golden age? And will sin otherwise always be? Explain its existence as we may - perhaps as the result, as the philosophers say, of our mutability, that is, of the possibilities and contingencies incident to imperfection-the sharp acćusation yet rests upon the universe of the presence of evil in its midst, with all its concurrent manifestations of moral and physical disorder and pain.

The problem of suffering is not a pleasant one, and the acknowledgment of pain among the lower animals does not make us happy. The "weight of all this unintelligible world" is assuredly a weary burden. Yet most of the brutes that are killed by man die an easier death and are really more humanely killed than when they die naturally, of wounds, or starvation, or old age. It is evidently not the purpose of Nature to aroid pain. When Whitman, in one of his rare conceptions, adclressed the sea as "the passionless wet" he spoke a true philosophy. There is no mercy in Nature. The ocean swallows up those unfortunately wrecked 
upon its billows without distinction and indiscriminately; the tornado sweeps away with no exceptions all that happens within its path; and the bursting volcano destroys whatever city lies at its base. The great Juggernaut of Nature is uncompromisingly cruel and impartial. Even the relief and soothing of unconsciousness, if we awake, does but for a time benumb our sufferings, and comes usually, indeed, from a shock, and only as a greater revelation of our helplessness. Aye, even when we use her own-born remedies, ' $t$ is but for the bruises and lacerations of her own-caused misery. Nature, indeed, herself is forced to be the main instrument of pain, and we are consequently face to face with the paradox on all sides of tragedy existing rampant even while the swallows soar the sunset skies.

Life is very full of tragedies. Pain is not so abnormal a condition in Nature (as we know it) as we sometimes think. Turn anywhither we will, and we are everywhere confronted with the presence and power of misery and disaster. It is the lot of every living being. And by suffering I do not mean mere physical pain (for some there be who would deny the body, and who would repudiate even the testimony of the senses), nor mental suffering (if so be there is a mind), nor anguish of soul (should there be a soul); but I mean pain of any sort, to be experienced in any way whatsoever. If you have no body, possibly you will know pain in the outlook of the imagination; if you have no mind (as is quite likely, if you think you have no body), it is possible you will have depression of soul; and if you have no soul (which God forbid!) it is 
possible that you, a mere beast, will then have to complete the circle and acknowledge pain again in the body. But whatever you have, one thing is certain, that, sooner or later, in some way or another, "in mind, body, or estate," as the Prayer Book says, you will have to encounter pain and misery in life. I do not think that we should try to minimize or evade the fact of pain. What in so doing do we gain but a makeshift, in itself a source of displeasure in our perplexity? Comedy itself is but a mask for tragedy.

Life, I say, is full of tragedies. Perhaps that is one significance of Christ's ministry, that tragedy is what we must expect upon earth: tragedies not only in human life-greater and consequently capable of more suffering than any other-but in the animal world, with the birds and beasts and fishes and all animal life, and among the plants also, beautiful expressions of plant life crushed or their growth thwarted by the survival of stronger neighbors. Tragedy is an ineradicable part of the experience of living - not falling heavily upon all alike, but, in greater or less degree, coming to all living things in the experience of heartless, fateful limitations. It is the saddest part of life, sadder even than unnecessary pain; for from such pain one may recover and have strength again, but tragedy is permanent loss and failure. Men do their best, they say, but somehow circumstances are against their achievement; and if through no fault of theirs they fail, and yet live courageously and bring success from limitation, the tragedy but becomes the darker. There has thus been no profounder disquisition on evil than Hamlet's soliloquy : 
"To be, or not to be,-that is the rquestion:

Whether ' $t$ is nobler in the mind to suffer

The slings and arrows of outrageous fortune,

Or to take arms against a sea of troubles,

And by opposing end them? To die,-to sleep, -

No more; and by a sleep to say we end

The heartache and the thousand natural shocks

That flesh is heir to,-'t is a consummation

Devoutly to be wish'd. To die,- to sleep,-

To sleep! perchance to dream! ay, there 's the rub;

For in that sleep of death what dreams may come

When we have shuffled off this mortal coil,

Must give us pause: there's the respect

That makes calamity of so long life;

For who would bear the whips and scorns of time,

The oppressor's wrong, the proud man's contumely,

The pangs of dispriz'd love, the law's delay,

The insolence of office, and the spurns

That patient merit of the unworthy takes,

When he himself might his quietus make

With a bare bodkin? who would fardels bear,

To grunt and sweat under a weary life,

But that the dread of something after death,

The undiscover'd country from whose bourn

No traveler returns, puzzles the will,

And makes us rather bear those ills we have

Than fly to others that we know not of ?"

The whole of life thus seems to be interpenetrated with tragedy, with pain. Man can not escape it: and get down among the lower animals, live with them, and be among them, and you will find suffering and misery there also. Men not infrequently cause tragedy in their relations with the rest of the animate world, sometimes knowingly and purposely and remorselessly, and sometimes unwittingly as undesignedly a partner of natural law. Tragedy is indeed inwoven into our very existence. Whenever we mow our lawns the Jug- 
gernaut of the lawn-mower grinds and crushes numbers of the tiny inhabitants of the grass, and whenever we cut our hay or harvest our grain the merciless sickle slashes and tears them in pieces. It is one of the inevitable accompaniments of life, even though we wish it not, that in many ways, however unconsciously or unintentionally, we should constantly be causing pain. It is blinded from our eyes, and we do not see it.

Nature is cruel and merciless, you say. Yes, that is true. Pain falls, in the realms of Nature, as generally upon the weak and defenseless as it does in the case of mankind. But the beautiful and refined lady who has her horses' tails docked and has the wings of a tern in her hat-is she so sweet? Is she not cruel also? That there is cruelty in Nature is true, but cruelty and the infliction of tragedy are not more absent from the life of intelligent men and women.

Yet alas! Nature has her tragedies, and has them relentlessly. Even the mosquito has its parasite. The laws of Nature are very inexorable; she is no respecter of persons. Every man--aye, every living beingreceives the penalty for a violation of them. I believe that the life of the woods is happier than man's, that there are an unalloyed gladness and a freedom from fear which man generally does not know; but I believe-indeed, I have seen it, and I know-that, with all the coy shyness, real and terrible tragedy is there also. It is especially heartrending to witness tragedy among animals that are particularly attractive and winsome, those that we love. I think of Shakespeare's fine old line, 
and 't is appropriate in the case of animals as with men, when misery and inequality come to them.

It is not a pleasant picture that John Fiske gives, in his "Through Nature to God," when, in his discussion of the mystery of evil, he speaks of the reality of the perpetual, unintermittent tragedy and rapine that underlie the apparent peacefulness of the fields:

"Any summer field, though mantled in softest green, is the scene of butchery as wholesale as that of Neerwinden and far more ruthless. The life of its countless tiny denizens is one of unceasing toil, of crowding and jostling, where the weaker fall unpitied by the way, of starvation from hunger and cold, of robbery utterly shameless and murder utterly cruel. That green sward in taking possession of its territory has exterminated scores of flowering plants of the sort that human economics and asthetics stigmatize as weeds; nor do the blades of the victorious army dwell side by side in amity, but in their eagerness to dally with the sunbeams thrust aside and supplant 'one another without the smallest compunction. Of the crawling insects and those that hum through the air, with the quaint snail, the burrowing worm, the bloated toad, scarce one in a hundred but succumbs to the buffets of adverse fortune before it has achieved maturity and left offspring to replace it. The early bird, who went forth in quest of the worm, was lucky if at the close of a day as full of strife and peril as ever knighterrant encountered, he did not himself serve as meal for some giant foe in the gloaming. When we think of the hawk's talons buried in the breast of the wren, while the relentless beak tears the little wings from the quivering body, our mood toward Nature is changed, and we feel like recoiling from a world in which such black injustice, such savage disregard for others, is part of the general scheme." 
I do not count death in itself as the greatest of evils; for death, as a necessary part of the life that now is, and not a calamity, comes rather as a release, even through the gateway of pain-surely better than perpetual suffering - in its own time. And the various and manifold incitements to rapine are, too, I suppose, necessary in this our world-the birds devouring the insects, the owl clutching the little wood mouse, the fox killing the duck, man hunting for game. It is a law of life as now constituted (I do not say that it is God's law) that we should live upon even our best animal friends. So, says the old verse:

\footnotetext{
"Let dogs delight to bark and bite,

For God hath made them so."
}

Now I do not think that $\mathrm{He}$ did. Evil, that is, to my mind, has not been a necessary, but a possible, accompaniment of free will. It did not (and does not) inhere in the very nature of things; but, having once been chosen, its effects have so been transmitted into all life that pain everywhere now is a recognized phase of existence.

But to particular and concrete cases of tragedy in the fields. Mr. John Burroughs has an interesting paper, entitled "The Tragedies of the Nests," in his "Signs and Seasons," in which he gives several examples of the struggle for existence which the young birds have to go through, and the necessity for constant watchfulness on the part of the old birds against their prowling or hooting enemies. Mrs. Olive Thorne Miller and other writers on birds have also spoken of the tragedies that frequently interrupt the peaceful 
progress of their nesting. I shall transcribe a few sentences from Mr. Burroughs's paper:

"The tender households of the birds are not only exposed to hostile Indians in the shape of cats and collectors, but to numerous murderous and bloodthirsty animals, against whom they have no defense but concealment. They lead the darkest kind of pioneer life, even in our gardens and orchards, and under the walls of our houses. Not a day or a night passes, from the time the eggs are laid till the young are flown, when the chances are not greatly in favor of the nest being rifled and its contents devoured-by owls, skunks, minks, and 'coons at night, and by crows, jays, squirrels, weasels, snakes, and rats during the day. Infancy, we say, is hedged about by many perils; but the infancy of birds is cradled and pillowed in peril."

$\mathrm{He}$ tells also of the frequent rifling of orioles' and other birds' nests, of the occasional death of both the old and young birds by accidental causes (such as entanglement in the hairs of their nests), and of the maraudings of their many destroyers.

His paper has recalled a few instances of tragedy in bird life that have come under my own observation.

One day, while clearing out a thicket, so that the larger trees would have more light and space, and could grow better, we cut down a maple sapling, and, as it fell, two eggs splashed out on the ground beside us. We found that we had unwittingly, but none the less absolutely, destroyed a little bird's nest which had been concealed among the thick foliage. We had not seen it, although we had noticed a bird or two around there; but there it was, all torn and bedraggled, and fragments of the speckled egg-shells lay scattered about it. 
It was pitiful to see the little pair, when they came and found their home ruined and desolate. At first their attitude was one of alarm and even wild anxiety. They fluttered from limb to limb in the trees near by, and peeped and peeped in shrill, high tones of distress; but when they finally realized what had happened, and saw the utter loss of all their labor, their little home destroyed, they flew to an elm a short distance away and gave vent to the saddest, most pitiful little sounds that I think I have ever heard. The beautiful little feathered creatures had lost their home, and it meant as much to them, doubtless, with what perceptions they may have, as the loss of our homes would to us, with our larger life. No longer could they come flying in happiness through the leaves and peep over the nest to the speckled eggs, and there was no hope now of a little brood from that nest. It was certainly, for them, a tragedy, and it had been caused by man, too; and perhaps that has made them suspect man. And yet no one would have been less likely or willing to do such a thing than either of us. It simply could not have been helped. Well, after a few minutes of mourning, these two flew away together, and we never saw them again. We were not quite certain as to the kind of birds they were, but their coloring, as I recollect it, was much like that of the ordinary little chippy, which, however, usually builds its nest not so high from the ground. My hope has always been that they built another nest, and had four more speckled eggs, and finally had the pleasure of bringing up four naked, scragly little young ones, and I think they did.

Speaking of birds' eggs, what a passion it is among 
boys to collect them! It is often overdone, and results in cruelty and damage to the nests; but not always, and how it takes the boys out into the woods and fields! Indeed, I know of one brown-eyed enthusiast who was the possessor at one time of some few dozen varieties of birds' eggs, gathered by long journeyings from the woods and the pastures, and obtained by dint of hard scrambling and climbing-but obtained, and blown, and labeled, and arranged in a box; and what an interesting collection of the beautiful little spotted and fragile things it was! How variously colored and speckled they were, and how we learned.from his box of eggs of the habits of the feathered tribe; and how delightful it was to find out what bird a certain kind of egg belonged to! It was one of the beneficent provisions of the Mosaic law that, if a man must gather birds' eggs or destroy the nests, "thou shalt not take the dam with the young;" that is, so to speak, if evil comes upon you, do not let it go too far! But the rather be kind; let not mercy give place unto wrath.

Pain, be it allowed, is more real to us, more excruciating to our sensitive natures, more complex and more intense. Yet suffering-and great pain-is none the less an actual fact among animals. So far as I have been able to observe it, pain with them is not of so long duration as with us, nor so keen, in proportion as their blood differs from ours in its consistency. But the tragedy of a torn nest is no less a tragedy for a feathered pair, simply because it is of less consequence, and happens to a lower order of beings, than is the burning of a handsome dwelling for a man and his wife. We rebuild our homes and go to the painful 
toil of making the fireside over again; the birds gather some hair and bits of moss, and form a new nest on a bough. But who shall say that the fact of sorrow was not as real, and proportionately as poignant, in the one case as in the other? I know that it is, for I have been among them, and have seen their pitiful grief; and perhaps, in their brief sorrow and steadfast facing of the future, they are wiser than we, who brood sometimes for years over our misfortunes. Let us not belittle their grief because it is little, and because they are little. "Are not two sparrows sold for a penny? and not one of them shall fall on the ground without your Father." Is that not tragedy which was implied even there, in that saying of our Lord's of centuries ago?

Sometimes the nests of birds are not put together very compactly or securely, and a strong wind or a storm may loose them from their moorings, and either dash them to the ground, or so move them from their supporting network of twigs that the eggs will roll and fall, or that the raising of a brood becomes a serious matter and at the least a precarious business. I have noticed this especially in the case of the flimsy nests of the turtle dove, which are little more than a few twigs massed together on a bough.

I once found and prevented what might have been a very terrible little tragedy by happening to notice a robin acting rather singularly in the top of a pear-tree in our yard. It had been fluttering in the tree for two days, but I had thought it was building its nest, and that its mate was bringing the bits of straw for it to weave. But this day it fluttered and acted very piti- 
fully, and I climbed the tree to see what was the matter. The poor robin had a string, a piece of stout cord, entangled all around its feet, having evidently been caught while trying to use the string for its little home; and the string was all wound around and in among the twigs of the tree. It had indeed been ensnared by the fowler. I broke the string, and released it, and it flew away with its mate, who had been fluttering piteously by its side while I was there. If I had not freed it, it would have died, because the cord was quite strong, and was doubled and twined about its little leg again and again, so that it would have been impossible for it to escape, and it would have starved and perished miserably. As it was, it had become very thin from lack of food, and was almost exhausted from its exertions. It was not able to fly far when I let it go, but kept getting gradually closer to the earth until, a couple of rods away, it lit on a pile of brush, steadied itself a little rockingly, looked at the mark of white string on its leg, and settled itself for a thankful restin freedom again, with its mate by its side! Many birds have not been so fortunate as this one was, but have died a slow, lingering death in the woods. $\mathrm{Mr}$. Burroughs, I recollect especially, relates how a bluebird was similiarly entangled with a horsehair of an oriole's nest, which it had visited; and it was found dead later, the hair having in some way become inextricably looped about it, and "was yet hanging in September, the outspread wings and plumage showing nearly as bright as in life"-a pitiful tragedy.

Perhaps the saddest thing, though, that I have yet seen in Nature was one of these beautiful, soaring 
chimney swallows that had become transfixed on a lightning rod near a chimney. It had doubtless darted down toward the chimney, and for some reason-either because the wind blew suddenly or because it did not see the rod-had gone straight on to the steel point. It had pierced its breast through, and there, alone, it had died, with no one to help it. When I first noticed it, it had become nothing but skin and bones and a dangling mass of weather-beaten feathers-dead long ago.

I recollect also that some of the boys set fire to an old dead stub one day, and, in so doing, unwittingly burnt up a young family of bluebirds which had their home within. The cries and actions of the old ones, when they saw their house in flames, were pitiful in the extreme. This, of course, was accidental, and, when discovered, was too late to rectify. But what shall we say of those other cases, so many of which are intentional, in which pain and tragedy are purposely and ruthlessly inflicted upon our feathered and furry brothers by devilishly inspired mankind? What do you suppose the dog thinks of the vivisectionist, anyway?

Birds seem to know man, and somerimes to rely on him. I have had two bluejays scream loudly and fly within a foot of my face, and show terror and almost ask for protection, when a big cat happened to be in a tree near their nest. He knew where it was, and that there were young ones in it, and he was making for the nest. I went to the tree and scared him down, and as he scuttled away the jays darted at him and followed him awhile, and then came back to their little home 
and flitted about, silent again, in perfect peace and security. Now I think they asked me to do that. To one who is sympathetically disposed toward animals there is frequently a very close relationship, almost an understanding, between them. A pair of wood thrushes used regularly to build their nest in our yard, sometimes in a maple, sometimes in a pear or an apple tree, and the male would select the wildest and most picturesque little spots in the yard, and there he would sit at twilight-in the leafy branches of an elm, say, near the nest-and sing away his wildwood love-song. They became accustomed to my presence and seemed to like me, and used sometimes to approach warily till within a foot of me, as I sat on the bench and read. One day in particular I remember, when in a chair on the porch, that one of the pair came flying toward me, intending (as I supposed) to alight on my shoulder; but I was startled (not seeing it in time) and waved it away, though even then it remained perched on the railing beside me for a moment. I think that the quiet spotted wood thrush is my favorite bird. A farmer one day, in speaking of the birds in his locality, said to me, "There is one bird that comes a little later than the others in the spring, and likes the little thickets, and sings there almost like a flute. I wonder what it is." I listened one day in the place he had told me, and soon, as I waited, floating out on the air came the notes of the bird. It was the song of the wood thrush.

I once found a song sparrow covered with warts, or excrescences of some sort, which a dozen others werc pursuing and trying to kill. They pecked it and pecked it, as it made its way along with drooping wings, but 
I finally captured it, and scared the others away. I took it home and we tried to help it, but I finally killed it, after we found it could not be cured. Its wings and its head and beak were covered with these singular bumps. I have seen hogs try to kill one among them that was sick, gouging it and gouging it, as if to get it out of the way and end its misery; and other animals, I am told, do the same when one of their number becomes helpless.

Walking along one day, I discovered a locust with one wing off, clumsily flopping about on the planks. He tried to fly, but could n't, and finally crawled over to a beech, and made his way up again to the life of the branches, his old life, where he might die. I have been much interested in locusts. They have many enemies; birds devour them, and I have seen many a one flying with a sizzling locust in its beak; cats and even ants also will eat them. I was quite surprised one time at the actions of one which had just come out of the ground in its pupa state, before shedding its shell. I noticed it in a rather conspicuous place on a walk, and, fearing that it might be crushed by the passers-by, I picked it up and placed it at the foot of a little maple. It was amusing, the avidity with which it took the hint and began slowly to climb the tree in its unwieldy armor (what a bother it must be to be a chrysalis, anyway!), as if having come upon-a little suddenly, and by some greater providence than his own-the very goal which he had all along been seeking, and been seeing through his glassy, scaly eyes.

There are, of course, many other tragedies in $\mathrm{Na}$ ture. One life feeds upon another, even if that other 
must be taken by pain and violence. The whole creation seems to be preying upon itself. Tragedy is the present law of growth, even of life. The very words themselves-hawks, owls, weasels, skunks, wolves, dogs, panthers, etc.-bring up a host of bloody images and murders. You have simply to watch the barnyard fowls in their excursions about the farm to see tragedy on a large scale among the insects and reptiles. Nor does it stop simply with one instance. The weasel sucks the blood of the chicken, the hen gobbles down a grasshopper or a frog, and so on, so far as I know, ad infinitum. Savagery has apparently been very contagious.

I have often disturbed mice in shocks of fodder or in wood-piles. Farmers frequently plow up young rabbits and mice and moles, and find nests of quails' eggs or those of prairie chickens when mowing. Cattle are continually trampling down nests when brushing through briars and bushes. I am constantly reminded of Burns's poems "To a Mouse" and "To a Mountain Daisy." Readers of Thomas Hardy will remember his touching description, in "Jude the Obscure," of the wounded rabbit crying in the snare. Burns, again, reveals his sympathetic nature in his poem "On Seeing a Wounded Hare Limp by Me." Sometimes a snake is cut all to pieces on the meadow, and I have seen a dog who, in the exhilaration and joy of life in the fields and grass, had bounded in front of the mower and had his legs cut off and mangled. We had to kill him afterwards, and it seemed as if he understood what the old rifle was for, from the look in his eyes.

I remember once finding a little puppy which had been lost in the woods. I had heard his cries, and had 
thought he had been poisoned or was hurt, and went to help him. I followed his pitiful sounds, and found him alone in the most desolate part of the woods. $\mathrm{He}$ had evidently been left there by some man to die, and had been there now alone for some days. The starvation and thirst had caused him apparently to become insane, so that he seemed not even to be conscious of my presence. I brought him home, and on the way he was taken with a kind of fit, and cast up green pieces of weeds and grass, which he had eaten out there in his fever. We fed him on milk and bread, and he ate it so eagerly. But the next day he was taken again, and immediately the old wild look came into his eyes, and he made his way back to the woods, and we heard his strange cries once more. I took the rifle, and found him again wandering and moaning in his insanity. $\mathrm{He}$ did not notice my presence any more than that of a stump, but finally, when I poked at him with my gun barrel, a gleam of remembrance seemed to come into his eyes for an instant, and he came up to me and wagged his tail-only to relapse again into his insane life. And then I killed him. And as I watched himhis life-blood trickling, the great ragged wound, the convulsive gaspings, and final stiffening-out there alone in the woods bending over his frail little body, I felt that I was being taught anew of the terrible but sublime mystery of death. His was the same death that you and I are to know, and his red blood had meant as much to his brief life as yours and mine does to ours. He had done me no harm, but I felt that in his case to shoot him was one of those things that we might call a mercy. Poor little fellow! He had very beautiful eyes. 
Is not insanity counted a terrible thing with us? Was not his insanity also a tragedy? He might have spent life happily among the woods, sniffing the leaves for the trail; instead, he wandered back to the forest, instinctively, as to his home, his intelligence lost, crazed by the pain which his masters, in their cruelty, had brought upon him. Equally with us, I say unfulfilled life for any creature is a tragedy, and I do not know of the remedy in this world.

The most heartless crime that I think a man can perpetrate upon a fellow mortal is to feed a dog upon ground glass. This causes a most horrible and painful and lingering death. We once had a fine, intelligent shepherd dog who was killed by that method, having in some way incurred the hatred of some lover of wickedness. He was in the woods two days before we learned where he was, and there I found him, half dead, and with his hind legs paralyzed. He still recognized me, but he was dying. His cries, as he lay stretched upon the leaves, still linger in my ears. Now how did pain serve to him as a ministry of discipline? Was it not a supremely heartless tragedy?

I am amused at the sheep ("the silly sheep"), and at their lambs, as they go rollicking about. Yet even sheep have their tragedies; and I suppose the culminating tragedy of their lives, to them, is when they are driven away down the dusty turnpike to the slaughter pen by the very shepherd who has fed and cared for them. One instance especially I shall always remember. It was lambing time, and we had been with the ewes. One of them lay in evident misery, and we went to her. She had suffered great pain, and had hoped to nourish 
her offspring; but she turned about her great mother eyes toward it, only to be disappointed and heartbroken. Her lamb had been born dead.

Thoreau, in his journal ("Winter," February 5, I 854 ), once jotted down a few thoughts upon a muskrat which are worth reading:

"Shall we not have sympathy with the muskrat, which gnaws its third leg off, not as pitying its suffering, but through our kindred mortality, appreciating its majestic pains and its heroic virtue? Are we not made its brothers by fate? For whom are psalms sung and mass said, if not for such worthies as these? When I hear the church organ peal, or feel the trembling tones of the bass-viol, I see in imagination the muskrat gnawing off his leg. I offer up a note that his affliction may be sanctified to each and all of us. . . . When I think of the tragedies which are constantly permitted in the course of all animal life, they make the plaintive strain of the universal harp which elevates us above the trivial. . . Eyen as the worthies of mankind are said to recommend human life by having lived it, so I could not spare the example of the muskrat."

Dr. W. C. Gray, in a paper upon "The Tragedies in Nature," in his "Musings by Camp-fire and Wayside," has also written of the existence of pain in the animal creation-the owl pursuing the duck, the hawk after the pigeon, the wolves in chase of the doe-but sees in these a benign intention and, after all, an alleviation. This is often very beautifully true, and the evil of pain then ceases in its own existence.

I hate to take the life of a fellow creature; yet I have. And the dripping, sputtering blood, the eyes still beautiful, have wrung my heart, while, neverthe- 
less, I still went on in the triumph of sport. I am not inclined, however, to think that hunting and trapping. are an unmixed evil. Both, it is true, cause pain to the animals hit and caught; and yet, even then, these same animals die more quickly and with less suffering than in the lingering way of Nature. I shall not greatly encourage these pastimes, though I used to love them and still do, and think they are beneficial in more than one way. But shall we not, in every way we can, as our better instincts prompt and guide us, seek to lessen and to alleviate the misery, wherever found, in this our common life, and thus play the part of kindness in our world in a mission of mercy to our fellows of the wild? We can at least do that.

I acknowledge that the position of the vegetarians is impregnable. It is true that the Lord, at the creation, said that the herb of the field and the fruit of the trees were to be as meat for our forefathers; that it is only after the fall that we find man sacrificing the firstlings of his flock; and that it was not until past the flood that the Lord openly sanctioned to Noah the eating of flesh. Yet, and notwithstanding, I find myself, along with millions of other human beings, so completely transformed by the heredity of the ages that, if I find I can get hold of a good piece of beefsteak or some other savory meat, and am hungry after a day's hard labor-well, I am simply going to eat it! Tendencies can not be overcome in a day. That is-to complete my little allegory-evil has become so insistent, so paramount, so preponderant, so much of a "second nature," as we say, in life that, do what we will, we can not escape it. Henceforth, after the fall, pain-and 
the infliction of it - was to become the lot of wandering man.

But let us recur to the problem; and, to borrow the words of Mr. Le Gallienne, in his treatise on pain in "The Religion of a Literary Man," it is "the immemorial problem of the meaning of evil, the mystery of pain, the crux of theology, the darkest mystery of life." We have seen that we are perpetually confronted anew with the pressure of irresistible, overwhelming evil, with all its lowering, baneful, malevolent, pernicious effects, and with sorrow, sadness, woe, distress, agony, grief, misery, inequality, crime, disease - in a word, pain-as the fruit of experience. Pain does not present itself to the eyes of most men so much as a philosophic mystery as it does as an unavoidable fact. "We are confronted by a condition, not a theory." And yet a little as to the theory. Whence all this pain that is so universal? And why?

Now I do not say that joy is any less a mystery, or any less universal, than pain. I am confining myself in this paper strictly to the question of the relation of Nature to the experience of suffering. The presence of joy is quite another matter. Nature offers, to all living beings, an alleviation in constant presentations of what Walter Pater calls "the intricate omnipresence of beauty" (which in itself is indeed a sign of promise), and in the manifold possibilities of the enjoyment of their natures in the exercise of play, the sense of humor, the pleasures of discovery, and in many ways other than the paths of pain. There are laws other than the law of tooth and claw. But it is rather a utilitarian view of life which would say, "Let us seek 
pain, because of the pleasure that cometh in self-sacrifice." Martyrdom, of course, has always been a most heroic feature of human life; and yet who will dare to affirm that the pages of history would not be the brighter without it? Martyrdom, indeed, is one of the darkest blots upon civilization. Let us confront pain bravely, if necessary; but let us not think ourselves cowards if we avoid it. IVe were created to live happily; and Whitman was not so far wrong when he told us to seek Happiness and to diffuse it. Yet shall we all have to meet pain, nevertheless. The way of the cross, as Thomas à Kempis so profoundly said, is "the royal way."

But why, after all, should not man and Nature live without pain? Why should we be compelled to confront the spectacle of blasted lives, unfulfilled natures, premature death in the midst of usefulness and joy in one's labor? Why should Lincoln and McKinley have to die by the assassin? Why could not Lincoln have lived to enact his policy of reconstruction, and McKinley his of reciprocity? There were lessons brought home to the American people by their deaths that perhaps could not have been accomplished so well in any other way; and we have taken the lessons to ourselves, that they died that we might live. But what shall we say of the innumerable tragedies all over the world, except that by these, too, is brought home to us merely the ever-recurring problem of our destiny? Those who die thus, while not realizing as perhaps they might the fullness of their powers, yet have their individual loss, the evil of their personal sacrifice, translated into terms of beneficence for the rest of mankind. But what of 
the individuals themselves? How else lies their recompense? And shall we say also of the world of the lower animals and the rest of Nature that their pain is, too, but a vicarious suffering? To say that sorrow brings with it a greater good than would, or could, exist without it is all well enough as a theory, and may be true in some cases, but I can not accept it as a universal fact, applicable alike to all individuals. No, I find life otherwise. I am confronted with the evidences of genuine and implacable suffering in all the world of Nature. I simply have bravely to admit its existence, and to acknowledge that the presence of pain in the universe is an ineffaceable reality and an ever-returning, baflling mystery-in itself a source of pain.

James Hinton's book, "The Mystery of Pain," has been of much help to me. It is, indeed, "a book for the sorrowful." His argument seems to me at times to be somewhat vitiated by his apparent refusal to recognize the absolute reality of pain in an attempt to explain it away by showing that individual good comes from it, which is by no means universally the case, in the life that now is. The joy of sacrifice may under the circumstances be in many instances the best possible compensation for the undergoing of pain (and it is surely in that spirit that, when necessary, we should meet it), but it is not a substitute for the happiness of innocence; the sting remains, and the memory of evil. Schopenhauer was right at least in this, that he recognized the undeniable reality of evil as eril, and had perhaps more than any other philosopher an insight into its nature.

The only adequate explanation that I have to offer 
of the existence of suffering among the lower animals, as well as with men, and, consequently, of the deeper problem of the origin and solution of evil, is that suggested in the Scriptures-in the Book of Job, for example - that there is in very truth a spiritual conflict in the universe between the forces (shall we say?) of good and evil, and that pain, not only with us but with the rest of creation, is, and has ever been, perpetrated (in theological terminology) by our common Adversary. The Lord God brings his aims to naught by the fruition of love, longsuffering, peace, and gentleness; but the evil was there, and it was evil, and we have suffered pain, and I do not say that we could not have had the higher life without it. There seems to have been (all things point to it, in my mind) a considerable catastrophe at some time in the history of the human race, the effects of which extend even now unto all Nature. Man feli; and we have no record that he was unhappy before the fall. Sin is the transgression of the law; and with sin has come pain, perhaps only to be eliminated when we shall have learned, through the long schooling of the centuries, so to conform our lives to the indwelling of His presence that evil shall no longer be amongst us.

The supremacy of evil, however, can be but a temporal triumph. Pain is not an irremediable state of affairs. No one who has faith can believe that. Every one who holds serene any scrap of confidence that, after all, the world was not made to be a failure must believe, with Tennyson, that, though the vision is blinded from us by the veil, yet "somehow good will be the final goal of ill," and that in permitting evil it has not been the 
intention to condone it; but it has been permittedshall we say, in a paradox? - that it might eventually and forever be annihilated. I do not say what the process shall be; but influences, however subtle, are real, and the very effects of evil may be ultimately to rid us of it. Yet the final triumph of good must be, not from any development of evil itself, but in its absolute suppression and destruction, when God shall be "all in all."

So, sings Tennyson, in his "In Memoriam:"

"O yet I trust that somehow good

Will be the final goal of ill,

To pangs of Nature, sins of will,

Defects of doubt, and taints of blood;

"That nothing walks with aimless feet;

That not one life shall be destroyed,

Or cast as rubbish to the void,

When God hath made the pile complete;

"That not a worm is cloven in vain;

That not a moth with vain desire

Is shrivel'd in a fruitless fire,

Or but subserves another's gain.

"Behold, we know not anything;

I can but trust that good shall fall

At last-far off-at last, to all,

And every winter change to spring."

Man fell; but we are told there is to be a restoration to another Paradise, when God shall walk among men again, and be their God. It is none of our doing. "God so loved the world." Now I refuse to separate man from the rest of Nature, to elevate him on a superior pedestal, and to alienate these, our brethren of 
the fields; and I believe that the promises are applicable to them also. For evil came not from Nature as she fell created from the hand of God. Behold, everything was very good! The thorn is concealed beneath the rose, but the rose itself is beautiful. Evil came from the Tempter. I want to see the devil recognized as responsible for some of the evil that is in me and the rest of creation. Nature assumes her various forms of life-and lo! comes "the Fall," as we call it (man's fall), and enters into them. Man thus is not the only being that suffers ("the whole creation groaneth and travaileth in pain together"), nor is it to man alone (surely!) that the promises are given. For if there be no recompense for undeserved loss in the animal world, then is there no justice, and life becomes hopelessly and forever an inscrutable mystery, and the understanding itself becomes darkened. But with this view of an ultimate release from pain in some final restitution all becomes clear and hopeful that otherwise is but a sad despair. We may not see it in our time, but that the light will come who can doubt? Said Thoreau, at the close of his "Walden:" "There is more day to dawn. The sun is but a morning star."

$\mathrm{He}$ is a profound thinker, Mr. Henry Mills Alden, who in his "God in His World" has expressed my thought in this way:

"If we know not what we shall be, neither do we know what Nature shall be, in her on-going from strength unto strength. There is no antagonism between the Natural and the Spiritual. Humanity has been bound up with Nature from the beginning, and, through the Incarnation, this bond has become a sacrament. If we are to suppose that any change 
has passed upon what we call the material world, in consequence of or in sympathy with man's errors, it has not, as we have seen, been such as to effect the correspondence of its meanings, spiritually interpreted, with those of the kingdom of heaven, as revealed by our Lord; and, if there has been any change due to the perversion of human life, then may we expect that Nature will in like manner respond unto the renewals of our life."

Then, too, even in this life, Nature comes as a consolation in the very face of evil, and her wildness and reserve, her buoyancy and free life, her variety and constant surprises, are the springs of hope and joy to all earth's myriads of inhabitants; while in her deeper significance men learn of the truths of tenderness, of beauty, of mystery, and of far-away infinity, the flutenotes from wood and meadow interacting with the breezes among the trees and the greenness and the blue sky and the rippling water, to form one world-wide harmony, and to make existence a dream and a foretaste of immortality. The most beautiful music seems perfectly in attune with Nature, from the concerts of an orchestra to the simplest notes of the flageolet. The coy wood-ways of bird, beast, and flower-what a world we have!

Instead of a totally supernaturalistic creed shall we not add to the statement of our beliefs this affirmation: I believe in Nature! "I believe in the forest," said Thoreau, speaking of the necessity of wildness in our lives and literature, "and in the meadows, and in the night in which the corn grows." That was part of his creed, and his religion. Oh, yes! the world is full of 
suffering, even the birds and the wild doe. But Nature has not therefore altogether been depraved, because of pain, caused, according to tradition, by the entrance of a spirit alien to our world. Can we not interpret the facts of Nature poetically, and shall we not find in them spiritualizing influences instead of the mere brute forces? I think we can. I think we do. For, whether we will it or no, it is in the world that we live, and it is from the world that we derive most of the qualities of our better selves.

Pain thus, we may say, after all, should become an encouragement. It should be the constant reminder that our liberation is not so far distant; is, incleed, growing nearer day by day. And, if we have known happiness even when evil has been about us, surely, then, when pain shall have been banished, shall we escape from the beclouded understanding of this life into the blessedness of perfect peace, taking with us the things that we love, and leaving behind forever the things that have marred our progress.

Isaiah prophesies of the reign of righteousness in a beautiful passage (Isaiah xi, 6-9), which, while figurative, may perhaps some day also (let us hope) see some sort of a literal fulfillment:

"And the wolf shall dwell with the lamb, and the leopard shall lie down with the kid; and the calf and the young lion and the fatling together; and a little child shall lead them."

And, again, among the passages in the Bible that are the most stately, and that I hold closest to heart. are two others also, the one from Paul to the Romans 
and the other from the concluding vision of the Revelation. Says the Apostle (Romans viii, I 8-23):

"For I reckon that the sufferings of this present time are not worthy to be compared with the glory which shall be revealed to us-ward. . . . For we know that the whole creation groaneth and travaileth in pain together until now. And not only so, but ourselves also, who have the first-fruits of the Spirit, even we ourselves groan within ourselves, waiting for the adoption, to wit, the redemption of our body."

Says John, in his rhapsody, of the City of God (Revelation $\mathrm{xxi}, 3,4)$ :

"Behold, the tabernacle of God is with men, and He shall dwell with them, and they shall be His peoples, and God Himself shall be with them, and be their God: and $\mathrm{He}$ shall wipe away every tear from their eyes; and death shall be ro more; neither shall there be mourning, nor crying, nor pain, any more: the first things are passed away."

And we may believe that the beasts of the field, and the fowls of the air, and all the rest of the loved life of Earth, will not be forgotten in the realization of such a Consummation.

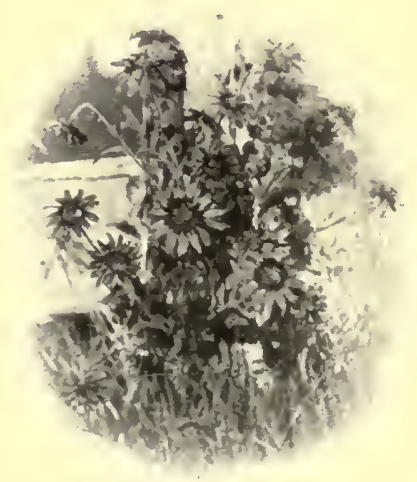




\section{THE WOOD THRUSH : A Sonnet.}

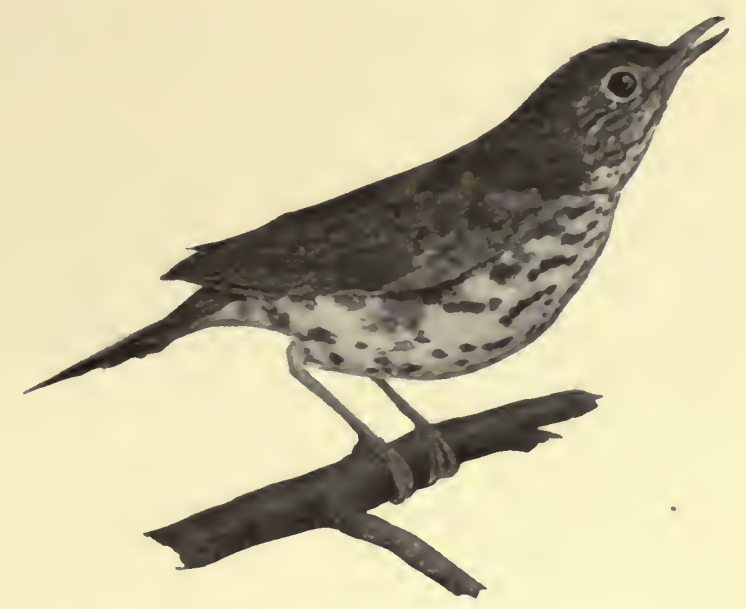

THE shy wood thrush, concealed amid the trees,

Pours forth his even-song unto his mate:

She, seated on the nest, alone in the late

Spring day. With her bright look she, peering, sees His joy. His woodland strains swell on the breeze, And trill, and plead, and not a tone abate, In accents sweet; his liquid eyes dilate;

The bubbling notes strike tinklingly like keys

Together, or, like drops of water, fall ;

His spotted breast heaves, and sends from his throat Rare native music, lays to her devote,

In his clear, flute-like, warbling call :-

And from these depths, his green-leaved habitude, It ceases.-Then the twilight solitude. 


\section{A Halatyer.}

Ffor tlye mantrouts lrauty and mystery of light; fart the

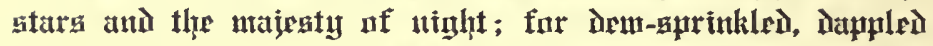

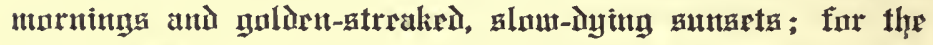

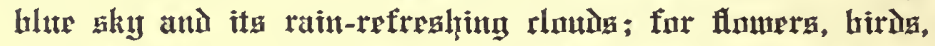

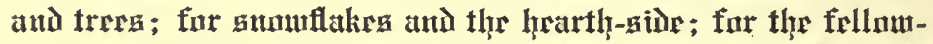

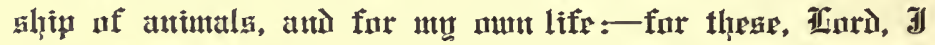

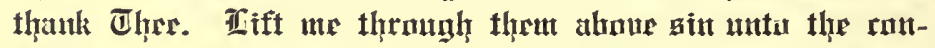

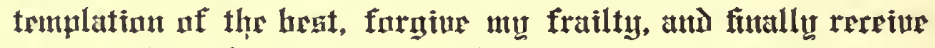
utr into CChrtiat'a redemuttun. Amen. 
" НАтн not old custom made this life more sweet Than that of painted pomp? Are not these woods More free from peril than the envious court?

Here feel we not the penalty of Adam.

The seasons' difference, - as the icy fang And churlish biting of the winter's wind, Which, when it bites and blows upon my body, Even till I shrink with cold, I smile and say 'This is no flattery'-these are counsellors That feelingly persuade me what I am.

And this, our life, exempt from public haunt, Finds tongues in trees, books in the running brooks, Sermons in stones, and good in everything.

I would not change it." 


DATE DUE

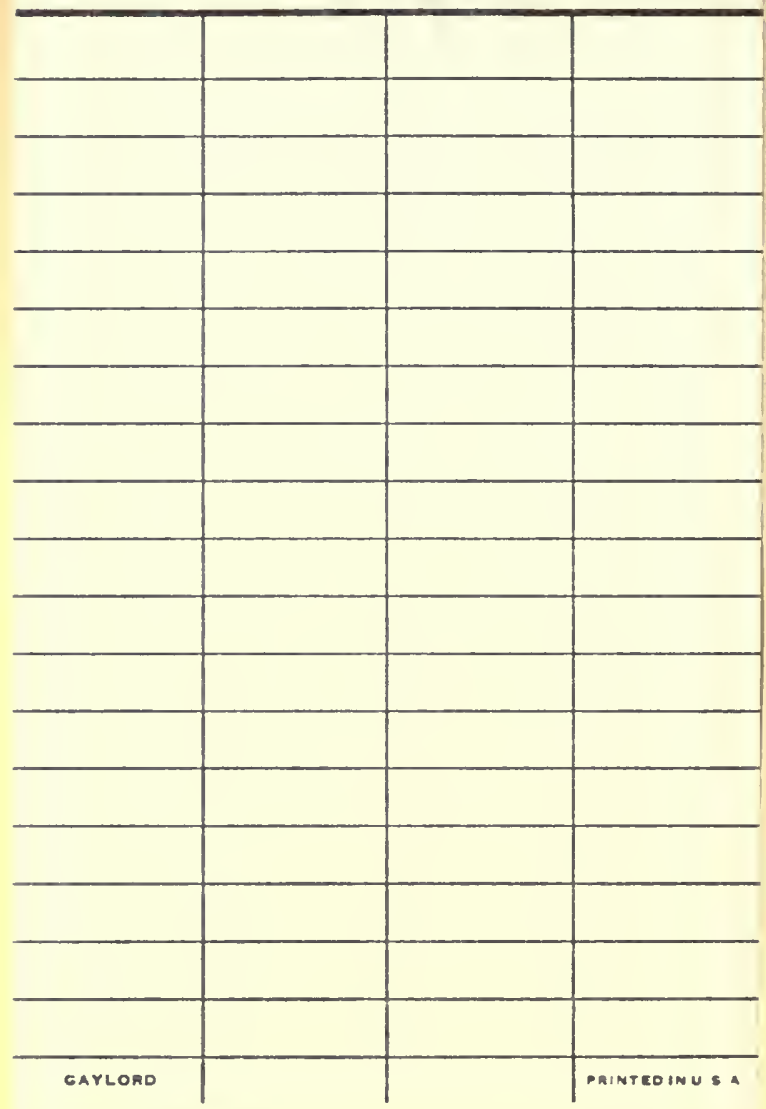


Huston, Paul Griswold. Around an old homestead :

UC SOUTEEN REGIONU LIBAPY FNOUTY

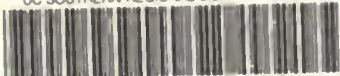

A 0006573976 
